\title{
SIMPLIFICAÇÃO E PRATICABILIDADE NO DIREITO TRIBUTÁRIO
}

DISSERTAÇÃO DE MESTRADO

Orientador: Professor dr. Paulo Ayres Barreto

Universidade de São Paulo - USP

Faculdade de Direito do Largo São Francisco

Departamento de Direito Econômico, Financeiro e Tributário

SÃO PAULO

2013 


\section{SERGIO SYDIONIR SAAD}

\section{SIMPLIFICAÇÃO E PRATICABILIDADE \\ NO DIREITO TRIBUTÁRIO}

DISSERTAÇÃO APRESENTADA À FACULDADE DE DIREITO DA UNIVERSIDADE DE SÃO PAULO COMO EXIGÊNCIA PARCIAL PARA OBTENÇÃO DO TÍTULO DE MESTRE EM DIREITO ECONÔMICO E FINANCEIRO

ORIENTADOR: PROFESSOR Dr. PAULO AYRES BARRETO

\section{SÃO PAULO}

2013 
Banca Examinadora 


\section{Dedicatória}

À minha esposa, Elcy, aos meus queridos filhos Murilo e Marina e aos meus pais Issa e Thereza, todo meu amor, orgulho e gratidão. 


\section{Agradecimentos}

A Deus por sempre me iluminar o caminho e tornar essa conquista possível.

À minha esposa, pela paciência, carinho e compreensão e que, nos momentos mais difíceis, soube com suas palavras de apoio confortar-me. Sem ela não teria conseguido concretizar este trabalho.

Aos meus filhos por sempre me apoiar e entender a importância desta conquista.

Aos meus pais, que com sua luta, possibilitaram que eu chegasse até aqui.

Ao meu orientador Prof. Dr. Paulo, com quem tive o privilégio de conviver e por seus valiosos ensinamentos indispensáveis à realização deste trabalho.

Todos que conviveram comigo nestes três anos e participaram desta empreitada são depositários de minha gratidão, seja pelo auxílio direto nos estudos seja por qualquer forma de apoio dada. 
"Se for desejado e concebido um Direito Positivo para um mundo imaginário ideal, o resultado será - é verdade - um Direito Positivo do outro mundo, mas também será para aquele outro mundo."

Alfredo Augusto Becker - Teoria Geral do Direito Tributário 


\section{Resumo}

Nos dias atuais, em razão de vários fatores, está se tornando cada vez mais impraticável à administração pública garantir o cumprimento da arrecadação e fiscalização tributária. As normas simplificadoras, criadas em nome da praticabilidade, é a solução de compromisso que permite a garantia da tributação de todos, mas sem o custo irrazoável do aparato administrativo para averiguação individual de cada caso concreto. Deixar de avaliar individualmente cada caso na aplicação da lei tributária pode representar uma afronta aos princípios da segurança jurídica, legalidade, igualdade, capacidade contributiva entre outros. Analisar as soluções que atendam esta demanda pela praticabilidade e que não agridam a justiça individual assegurada pelos princípios constitucionais é o que visa esta dissertação. Entre as técnicas de simplificação abordadas, ressaltam-se as presunções e as ficções. As normas simplificadoras, como objeto de estudo, serão identificadas dentro do universo das normas tributárias verificando-se sua finalidade extrafiscal. A Praticabilidade é estudada, trazendo-se um conceito, que a identifica como de caráter principiológico e sua relação com o princípio da eficiência. Como princípio a Praticabilidade é confrontada com: segurança jurídica, legalidade, igualdade, capacidade contributiva, justiça fiscal, discriminação constitucional de competências, proporcionalidade, razoabilidade, neutralidade e proibição de confisco, identificando os limites jurídicos impostos à sua utilização. No estudo de casos, estes limites são verificados e confrontados com o posicionamento mais atual da jurisprudência.

Palavras-chave: Normas Simplificadoras; Simplificação; Praticabilidade; Padronização; Presunções e Ficções; Planta Genérica de Valores; Pautas Fiscais; IPVA; Lucro Presumido; Substituição Tributária; Simples Nacional. 


\begin{abstract}
Nowadays, due to various factors, it is becoming increasingly impractical to government enforce the tax collection and enforcement. The simplifying rules, created in the name of practicality, is a compromise that allows the guarantee of all taxes, but without the unreasonable cost of the administrative apparatus for individual investigation of each case. Failure to evaluate each case individually when applying the tax law may represent an affront to the principles of legal certainty, legality, equality, fiscal capacity among others. Analyze solutions to meet this demand by practicality and do not harm the individual justice guaranteed by the constitutional principles is what this thesis aims. Among the techniques addressed for simplification, we emphasize the presumptions and fictions. The simplifying rules, as an object of study, will be identified within the universe of tax rules checking its extrafiscal purpose. The Feasibility study is bringing up a concept, identifying it as a principiológico character and its relation to the principle of efficiency. In principle the Feasibility is confronted with legal certainty legality, equality, ability to pay, taxation, constitutional powers of discrimination, proportionality fairness, neutrality and prohibiting confiscation, identifying the legal limits on its use. In the case studies, these limits are checked and compared with the most current positioning of jurisprudence.
\end{abstract}

Keywords: Simplifying rules ; Simplification , Practicability ; Standardization ; Presumptions and Fictions; Planta Genérica de Valores; Pautas Fiscais; IPVA; Lucro Presumido; Substituição Tributária; Simples Nacional. 


\section{Sumário}

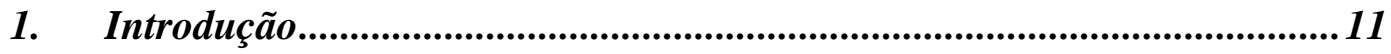

2. Propedêutica Geral .................................................................................... 13

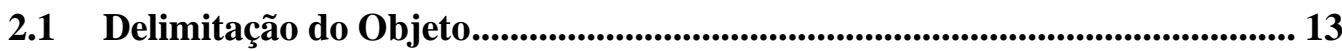

2.2 Método e Forma de Aproximação do Objeto....................................................... 14

2.3 Definição do Objeto............................................................................................... 16

2.3.1 Identificação das Normas Simplificadoras....................................................... 17

2.3.2 Normas Simplificadoras como espécie das Normas Tributárias ............................... 20

2.3.3 Normas Simplificadoras e a Extrafiscalidade ..................................................... 22

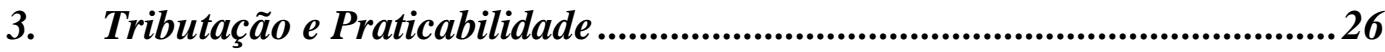

3.1 Demandas pela Simplificação................................................................................... 26

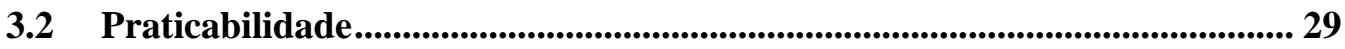

3.3 Praticabilidade como Princípio .....................................................................33

3.4 Praticabilidade e Eficiência na tributação ............................................................. 38

3.4.1 Limites para a Eficiência Administrativa .......................................................... 44

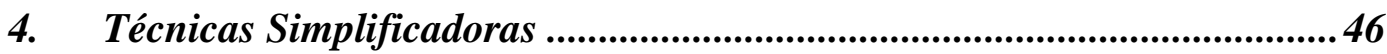

4.1 Indeterminabilidade como técnica legislativa..................................................... 49

4.2 Presunções e Ficç̃̃es.............................................................................................. 56

4.2.1 Conceito de Presunções, Classificação e Espécies ................................................... 56

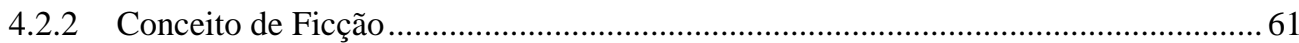

4.2.3 Funções e Utilizações das Presunções e Ficções na tributação ................................64

4.2.4 Presunções e ficções na estrutura da norma tributária........................................... 74

4.3 Padronização, Tipificação ou Regimes Objetivos................................................ 83

5. A Praticabilidade em face dos Princípios Constitucionais Tributários..... 87

5.1 Segurança Jurídica................................................................................... 89

5.1.1 Segurança Jurídica e Praticabilidade..................................................................... 93

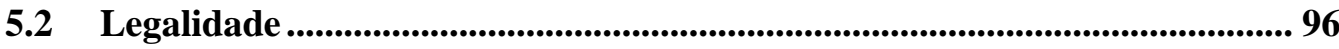

5.2.1 Legalidade e Praticabilidade .......................................................................... 98

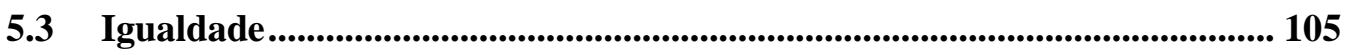

5.4 Capacidade Contributiva.......................................................................................... 109

5.4.1 Capacidade Contributiva e Praticabilidade ..................................................... 113 


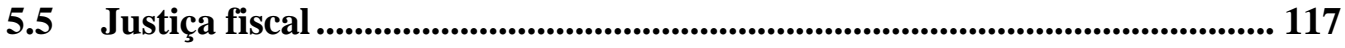

5.6 Discriminação constitucional de competências ................................................... 122

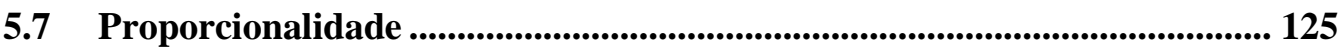

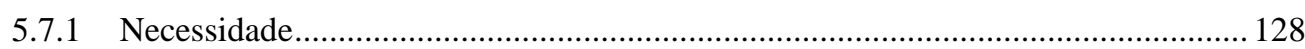

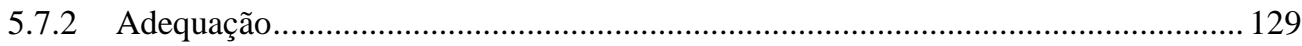

5.7.3 Proporcionalidade em sentido estrito ……………........................................... 130

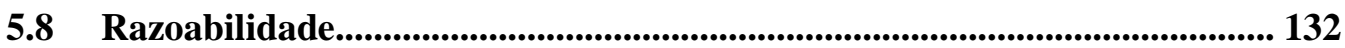

5.8.1 O caráter voluntário e opcional dos regimes objetivos ............................................ 134

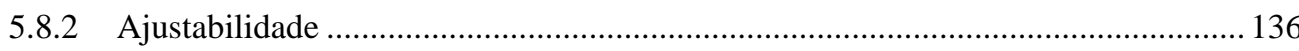

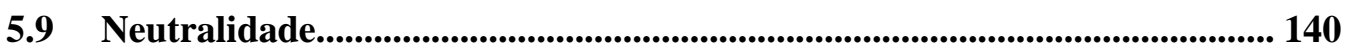

5.10 Proibição do Efeito de Confisco .............................................................................. 143

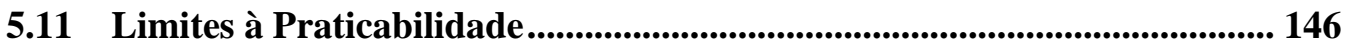

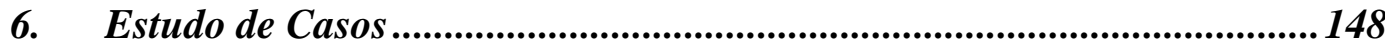

6.1 Planta Genérica de Valores ....................................................................................... 148

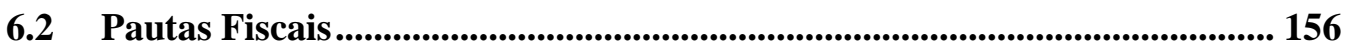

6.3 Tabela de Veículos Usados no IPVA................................................................. 162

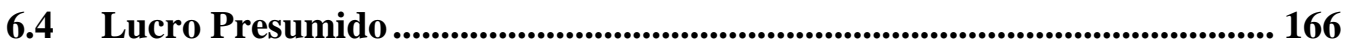

6.5 Substituição Tributária Progressiva ou "Para Frente" ............................... 170

6.6 Simples Nacional.................................................................................................. 197

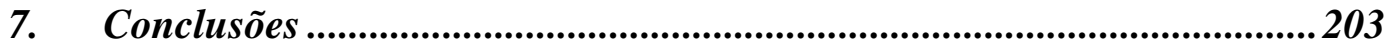

8. Referências Bibliográficas ..............................................................209 


\section{Introdução}

O direito não existe em si e por si, mas como um instrumento criado pelo homem para regular as condutas e intervir nos conflitos intersubjetivos, garantindo a convivência social. ${ }^{1}$

Se as normas jurídicas não forem passíveis de ser aplicadas sobre a realidade social, o direito perde sua natureza essencial de sujeitar os homens, mediante regras de condutas, a realizar ou não realizar determinados comportamentos.

A tributação representa um subgrupo destas regras jurídicas voltadas a retirar parte do patrimônio dos cidadãos, provendo os cofres públicos com os recursos necessários para a consecução dos objetivos do Estado Democrático de Direito.

Hoje já não se concebe a ideia de que a arrecadação consiste em um fim em si mesma, mas se justifica como instrumento voltado à redistribuição de riquezas a serviço de uma política social e econômica, ou seja, ser cidadão, em respeito ao princípio da solidariedade, significa contribuir para que o Estado possa construir uma sociedade livre com justiça social.

Sem uma aplicação eficiente das normas tributárias para todos, possibilitando ao Estado garantir a efetividade dos direitos fundamentais e cumprir seus fins sociais, a tributação deixa de ser um instrumento de realização de justiça.

A complexidade da vida moderna, consequência da explosão demográfica, da globalização e da multiplicação das relações econômicas, resultou num afastamento das normas jurídicas dessa realidade social em constante mutação.

Surge, neste contexto, a necessidade de medidas que possibilitem à administração pública, cada vez mais carente de recursos, aproximar o direito da realidade, simplificar as normas jurídicas e tornar praticável sua aplicação neste novo cenário.

As normas simplificadoras, criadas em nome desta praticabilidade, buscam trilhar neste caos tributário em que vivemos, uma solução de compromisso: garantir a tributação de todos, mas sem a averiguação individual de cada caso concreto, o que tornaria o custo do aparato administrativo irrazoável para o cumprimento da arrecadação e fiscalização tributária.

Todavia deixar de avaliar individualmente cada caso concreto para aplicar a lei a milhares de casos pode representar uma afronta aos princípios da segurança jurídica, legalidade, igualdade, capacidade contributiva entre outros. Buscar a solução neste embate da

\footnotetext{
${ }^{1}$ BECKER, Alfredo Augusto. Teoria Geral do Direito Tributário. 5.ed. São Paulo: Noeses, 2010, p. 76.
} 
praticabilidade com a justiça individual assegurada por diversas balizas constitucionais é o desafio proposto neste estudo.

Nossa proposta neste sentido inicia-se por uma propedêutica geral pela qual delimitaremos o objeto de estudo, método e forma de sua aproximação e sua definição, identificando as normas simplificadoras dentro do universo das normas tributárias e sua finalidade extrafiscal.

Em seguida abordaremos o relacionamento entre tributação e praticabilidade ao: enumerar as demandas pela simplificação; conceituar a praticabilidade; buscar seu caráter principiológico e sua relação com o princípio da eficiência.

No capítulo seguinte estudaremos as técnicas utilizadas na simplificação tais como: a indeterminabilidade; presunções e ficções; e, a padronização.

Estudar a praticabilidade em face dos demais princípios constitucionais tributários é a matéria do próximo capítulo, confrontando-a com: segurança jurídica, legalidade, igualdade, capacidade contributiva, justiça fiscal, discriminação constitucional de competências, proporcionalidade, razoabilidade, neutralidade e proibição de confisco, buscando delinear os limites impostos à sua utilização.

Por fim passaremos ao estudo de casos, pelo qual será possível analisar alguns exemplos de utilização de normas simplificadoras no direito tributário brasileiro e buscar na jurisprudência o entendimento atual sobre o tema da praticabilidade.

Ainda que cientes de nossas limitações frente aos desafios deste estudo e do posicionamento da melhor doutrina, deixaremos registrado nosso entendimento, sem a menor pretensão de definitividade, senão aquela de trazer alguma contribuição à reflexão e discussão sobre tão instigante tema. 


\section{Propedêutica Geral}

\subsection{Delimitação do Objeto}

Sabe-se que o conhecimento científico de um objeto de estudo implica a redução de suas complexidades ${ }^{2}$, pois qualquer que seja este, nenhuma pesquisa científica logrará êxito em esgotar totalmente o seu conhecimento, nem reduzir por completo tais complexidades.

Essa redução de complexidades do objeto que se quer conhecer, deve ser implementada, utilizando-se de cortes metodológicos e conhecimento jurídico, como uma das espécies do gênero do conhecimento científico, "não refoge a esse imperativo epistemológico, produto das ínsitas limitações do ser cognoscente". ${ }^{3}$

O primeiro corte metodológico proposto por PAUlo de Barros CARVAlHO, apoiado nas ideias de RICKERT, é fazer um corte inicial no continuum heterogêneo da realidade social, para propiciar o descontinuum homogêneo, "onde se demoram as entidades e as relações jurídicas, bem como o tecido do saber científico que as tem por objeto" ${ }^{4}$, ou seja, delimita o direito positivo como objeto da Ciência Jurídica.

O direito positivo pode ser definido como o conjunto de normas jurídicas válidas, criadas pelo homem para organizar os comportamentos intersubjetivos em direção aos valores que uma determinada sociedade quer ver realizados, num determinado território e historicamente determinada no tempo. ${ }^{5}$

Assim se "à Ciência do Direito compete o estudo do direito posto, nada além, nem antes e nem depois dele" e o direito posto é o conjunto de normas válidas, forçoso inferir que “o objeto de estudos da Ciência do Direito são as normas jurídicas e só elas. Nada além, nem antes e nem depois delas". ${ }^{7}$

O segundo corte realizado, considerando que onde há direito existe linguagem, implica necessariamente dizer que o estudo do direito é um estudo de linguagem, o que traz

\footnotetext{
${ }^{2}$ Neste sentido, Paulo Ayres BARReto doutrina que "o conhecimento de um dado objeto exige um constante caminhar em busca da redução de suas complexidades". BARRETO, Paulo Ayres. Contribuições: regime jurídico, destinação e controle. São Paulo: Noeses, 2006. p. 3.

${ }^{3}$ CARVALHO, Paulo de Barros. Curso de Direito Tributário. 17. ed. São Paulo: Saraiva, 2005. p. 12.

${ }^{4}$ CARVALHO, Paulo de Barros. Fundamentos Jurídicos da Incidência Tributária. 8. ed.. São Paulo: Saraiva, 2010, p. 24.

${ }^{5}$ CARVALHO, Paulo de Barros. Fundamentos Jurídicos da Incidência Tributária. 8. ed.. São Paulo: Saraiva, 2010, p. 24

${ }^{6}$ CARVALHO, Aurora Tomazini de. Curso de teoria geral do direito: o constructivismo lógico-semântico. 2. ed. São Paulo: Noeses, 2010, p. 84.

${ }^{7}$ Ibidem, p. 84
} 
como corolário a utilização das ciências da linguagem, particularmente a ferramenta da Semiótica no estudo da linguagem positivada.

O terceiro corte, que traz o direito como objeto cultural, reflete que o cientista do direito vai lidar com valores na linguagem jurídica e, em razão disto, aquele que se propõe a conhecer o direito não pode aproximar-se despojado de atitudes ideológicas, uma vez que a neutralidade axiológica compromete irremediavelmente a pesquisa.

A presença de valores nas normas jurídicas já tinha sido identificada por MIGUEL REALE ao esclarecer que: "cada norma ou conjunto de normas jurídicas representa, em dado momento e em função de determinadas circunstâncias, a incidência de certos valores". ${ }^{8}$

Os objetos culturais, construídos pelo homem tendo em vista certa finalidade, são reais, têm existência no tempo e no espaço, estão na experiência e são valiosos (positiva ou negativamente). Seu ato gnosiológico de aproximação científica é a compreensão e o método próprio é o empírico dialético.

O quarto e último corte considera para a Ciência do Direito o conjunto de normas jurídicas válidas, afastando-se o direito passado, formado pelas normas jurídicas que perderam a validade, e o direito futuro, consubstanciado nas normas jurídicas que ainda não adquiriram validade.

Fixamos assim, com estes cortes metodológicos, o direito positivo como objeto deste estudo e tendo como sistema de referência o conjunto de normas válidas dentro do ordenamento jurídico brasileiro, tomado como um objeto cultural ${ }^{9}$, impregnado de valores e que se manifesta em linguagem.

\subsection{Método e Forma de Aproximação do Objeto}

Uma vez delimitado o objeto, faz-se necessário para uniformização na apreciação do objeto dentro do processo de conhecimento científico, definir um método para a sua aproximação.

Como bem adverte PAUlo Ayres BARRETO, "a adequada aproximação de um objeto cultural, como é o direito, impregnado de carga valorativa, expresso em linguagem, por vezes imprecisa e ambígua, não é tarefa simples". ${ }^{10}$

\footnotetext{
${ }^{8}$ REALE, Miguel. Teoria tridimensional do direito. 5. ed. São Paulo: Saraiva, 1994, p. 75.

9 BARRETO, Paulo Ayres. Contribuições: regime jurídico, destinação e controle. São Paulo: Noeses, 2006. p. 3; CARVALHO, Paulo de Barros. Fundamentos Jurídicos da Incidência Tributária. 8. ed.. São Paulo: Saraiva, 2010, p. 24.

${ }^{10}$ BARRETO, Paulo Ayres. Contribuições: regime jurídico, destinação e controle. São Paulo: Noeses, 2006, p. 3.
} 
A teoria geral dos objetos revela que o ato gnosiológico de aproximação científica é a compreensão e o método próprio é o empírico dialético, "já que o saber, nesse campo, pressupõe incessantes idas e venidas da base material ao plano de valores e, deste último, à concreção da entidade física que examinamos". ${ }^{11}$

$\mathrm{O}$ fato de o direito manifestar-se em linguagem requer adotarmos o método analítico, o qual se mostra adequado para explorá-lo. O método analítico, utilizado na aproximação do objeto, consiste na construção do discurso científico pela depuração da linguagem natural que o constitui, i.e., na tradução da linguagem natural para a linguagem científica. $^{12}$

Mas o fato de o direito positivo ser tomado como um objeto impregnado de valores requer ainda a utilização da hermenêutica, pois "o conhecimento do conteúdo jurídico só se atinge mediante um ato de valorização do intérprete". ${ }^{13}$

CARLOS MAXIMILIANO doutrina que a hermenêutica "tem por objeto o estudo e a sistematização dos processos aplicáveis para determinar o sentido o alcance das expressões de Direito", isto é, a hermenêutica tem por objeto o estudo e a sistematização dos processos aplicáveis na interpretação, que revelam o sentido e o alcance das normas jurídicas. ${ }^{14}$

Assim, a hermenêutica mostrando-se apta a revelar o sentido dos textos legislados e com os referenciais culturais que os informam, consubstancia-se juntamente com o método analítico, em um método adequado para a Ciência do Direito, com a ressalva de que "a construção analítico-hermenêutica, no entanto, ocorre dentro de um processo dialético, de contraposição de sentidos, próprio do plano dos objetos culturais". ${ }^{15}$

Para o estudo do direito positivo, manifestado por linguagem, devemos nos valer da técnica ${ }^{16}$ da semiótica, mediante a qual poderemos investigá-lo.

TÉRCIO SAMPAIO FERRAZ JUNIOR ensina que pela técnica da semiótica o estudo das normas jurídicas poderá ser orientado pelos critérios sintáticos, semânticos e pragmáticos. ${ }^{17}$

\footnotetext{
${ }^{11}$ CARVAlHO, Paulo de Barros. Direito Tributário Linguagem e Método. 3. ed. São Paulo: Noeses, 2009, p. 18.

${ }^{12}$ CARVALHO, Aurora Tomazini de. Curso de teoria geral do direito: o constructivismo lógico-semântico. 2. ed. São Paulo: Noeses, 2010, p. 49-50.

${ }^{13}$ Ibidem, p. 222.

${ }^{14}$ MAXIMILIANO, Carlos. Hermenêutica e Aplicação do Direito. 3. ed. Rio de Janeiro: Forense, p. 13.

${ }^{15}$ Aurora Tomazini de Carvalho pondera que "método e técnica não se confundem", i.e., adotado um método, podemos nos valer de várias técnicas para estudá-lo, como a semiótica, a lógica, a axiologia, etc. CARVALHO, Aurora Tomazini de. Curso de teoria geral do direito: o constructivismo lógico-semântico. 2. ed. São Paulo: Noeses, 2010, p. 88.

${ }^{16}$ Ibidem, p. 46.

${ }^{17}$ FERRAZ JR., Tércio Sampaio. Introdução ao Estudo do Direito- técnica, decisão, dominação. São Paulo: Atlas, 2003. p. 124-133.
} 
Pelos critérios sintáticos, estudam-se os vínculos de relevância, subordinação e estrutura; pelos semânticos, os destinatários, matéria, espaço e tempo; e pelos pragmáticos, a força de incidência, finalidade e funtor.

Alinhado com este pensamento, PAUlo DE BARros CARVALHO ${ }^{18}$ expõe que o conhecimento de qualquer manifestação de linguagem jurídica pressupõe o estudo dos planos da sintaxe, da semântica e a pragmática.

Pela sintaxe estudam-se as articulações das normas entre si, como por exemplo, na relação entre a norma da Constituição e a da lei ordinária.

No plano semântico buscam-se as significações do direito, as quais permitem ligar a linguagem normativa à conduta do mundo social por ela regulada. Neste aspecto semântico deparamo-nos com o problema da vagueza, imprecisão e ambiguidade dos vocábulos jurídicos.

Por intermédio da pragmática, estudam-se como as normas podem motivar a conduta, realizando os valores da ordem jurídica.

Essa análise pragmática pela finalidade nos será útil, tendo em vista que nosso objeto de estudo, as normas tributárias simplificadoras, buscam possibilitar (ou ter por finalidade) a aplicação massificante da norma, com desprezo das diferenças individuais relevantes do ponto de vista legal.

Enfrentaremos na investigação de nosso objeto de estudo o sistema jurídico das normas tributárias válidas, mais especificamente as normas tributárias simplificadoras, utilizando o método analítico-hermenêutico, orientados pelas técnicas da semiótica, analisandoas pelos ângulos da sintaxe, da semântica e da pragmática e com supedâneo nas categorias da teoria geral do direito ${ }^{19}$, para determinar se o tratamento igual de casos desiguais, por força da simplificação, é tolerado pelo nosso ordenamento jurídico pátrio e quais seriam os limites.

\subsection{Definição do Objeto}

As normas tributárias, por várias razões que apontaremos nos próximos capítulos, muitas vezes sofrem um processo de simplificação ou abstração que resulta no surgimento das normas tributárias simplificadoras, as quais este estudo propõe-se a analisar.

\footnotetext{
${ }^{18}$ CARVAlHO, Paulo de Barros. Direito Tributário Linguagem e Método. 3. ed. São Paulo: Noeses, 2009, p. 212.

${ }^{19}$ PAUlo de BARros CARvalHo entende que ö hábito de certas reflexões filosóficas e o apelo frequente às categorias da Teoria Geral do Direito, longe de dificultar o acesso ao objeto da investigação, aparecem como condições mesmas do aprofundamento cognoscitivo. (CARVALHO, Paulo de Barros. Fundamentos Jurídicos da Incidência Tributária. 8. ed.. São Paulo: Saraiva, 2010, p. 25).
} 
A utilização de normas simplificadoras exige, de um lado, que examinemos os principais limites jurídicos das normas tributárias e, de outro, a colisão entre os princípios jurídicos que visam garantir a realização de direitos fundamentais no Estado Democrático de Direito, buscando determinar em cada caso qual a melhor solução.

Nossa pesquisa terá como ponto de partida a ordem jurídica, que se iniciou com a promulgação da Constituição Federal de 1988 e em razão da unicidade do direito, além de o direito tributário, faremos incursões em outras áreas tais como: direito econômico, direito administrativo etc.

\subsubsection{Identificação das Normas Simplificadoras}

Ao tratarmos de normas simplificadoras, faz-se necessário, em respeito ao rigor científico, definir especificamente de que normas estaremos tratando, dentre as várias acepções possíveis que a palavra "simplificadora" oferece.

Como simplificar significa "tornar mais simples, menos complexo" ${ }^{20}$, podemos assumir, entre outras acepções, que são normas simplificadoras tributárias: (i) as que diminuem e/ou eliminam as obrigações acessórias dos contribuintes; (ii) aquelas que visam simplesmente facilitar o pagamento do tributo; e (iii) as normas que atuam no sentido de reduzir ou atenuar a natural complexidade da legislação fiscal, visando tornar praticável a sua aplicação de maneira generalizada.

Por tratarem todas elas de tributação, sujeitam-se a princípios e normas do sistema jurídico tributário, mas com limites distintos. Eis a principal razão para realizarmos mais esse corte seletivo para nosso estudo.

Tanto as normas do primeiro grupo, que diminuem e/ou eliminam as excessivas obrigações acessórias dos contribuintes, como aquelas do segundo grupo, que visam facilitar o pagamento do tributo ${ }^{21}$, embora importantes do ponto de vista formal na arrecadação, não comprometem limites constitucionais como o princípio da igualdade, capacidade contributiva ou da legalidade e não farão parte do escopo deste estudo.

\footnotetext{
${ }^{20}$ Grande Dicionário Houaiss da Língua Portuguesa. Disponível em: < http://houaiss.uol.com.br/busca?palavra=simplificar >. Acesso em 27 de maio de 2013

${ }^{21}$ Como exemplo, no regulamento do ICMS do Estado de São Paulo (Decreto n. 45.490/00) existe a possibilidade para o contribuinte, que tiver mais de um estabelecimento em seu território, centralizar a apuração do imposto. Essa centralização resume-se na transferência de saldos credores e devedores para um único estabelecimento que irá efetivamente efetuar a apuração do ICMS devido por todos os estabelecimentos do mesmo titular, no respectivo mês de apuração. (Artigo 96 - Os saldos devedores e credores resultantes da apuração prevista nos artigos 87 ou 88, efetuada a cada período em cada um dos estabelecimentos do mesmo titular localizados em território paulista, poderão ser compensados centralizadamente, sendo o resultado, quando devedor, objeto de recolhimento único).
} 
Diante da realidade social, muitas vezes a administração, por razões de ordem prática, não consegue acompanhar os graus de diferenciação e individualização previstos na lei.

Neste momento são editadas normas de simplificação, objetos específicos de nosso estudo, com as quais o legislador se socorre de presunções legais e das técnicas de padronização, de forma a tornar praticável uma execução eficaz e econômica da lei.

A simplificação mostra uma tendência de disciplinar um número cada vez maior de situações, sob a regência das mesmas normas, desconsiderando-se as particularidades de cada uma delas.

Pelos custos inviáveis que a apuração individualizada de cada fato tributário geraria, a administração ao aplicar a lei, abstrai-se, na aplicação da lei, do potencial de diferenciação de tal forma "que lhe permita aliviar as suas limitadas capacidades no espinhoso apuramento dos factos tributários em toda a sua potencial diferenciação e individualização, obtendo assim, através duma ilegalidade necessária (LUHMAN), uma execução da lei o mais igual possível". ${ }^{22}$

É justamente essa simplificação pela qual passam as normas constitucionais no processo de positivação, quando do ato de aplicação, desconsiderando a real capacidade contributiva, que nos interessa analisar em maior profundidade.

Normas de Simplificação, neste estudo, não designam genericamente todas as normas que tornam mais simples o sistema tributário, mas entre estas, somente aquelas que o fazem renunciando gravar a verdadeira manifestação de capacidade econômica individual. ${ }^{23}$

Na aplicação do direito, ao emitir uma norma individual e concreta, o intérprete está modificando o sistema do direito positivo, contraindo-o, expandindo-o ou revisando-o ${ }^{24:}$ " $\mathrm{a}$ aplicação do Direito é simultaneamente produção do Direito". ${ }^{25}$

Relacionando a aplicação do direito com o fenômeno da incidência, FABIANA DEL PADRE TOMÉ pondera que: "trata-se de ato mediante o qual se extrai de regras superiores o fundamento de validade para a edição de outras regras, cada vez mais individualizadas. E é somente por meio dessa ação humana que se opera o fenômeno da incidência normativa em geral, assim como da incidência tributária em particular". ${ }^{26}$

\footnotetext{
22 NABAIS, José Casalta. O Dever Fundamental de Pagar Imposto - Contributo para a compreensão constitucional do estado fiscal contemporâneo. 3. ed. Coimbra: Almedina, 2012. p. 376.

${ }^{23}$ COSTA, Regina Helena. Praticabilidade e justiça tributária - Exequibilidade de Lei Tributária e Direitos do Contribuinte, São Paulo: Malheiros, 2007, p. 171.

${ }^{24}$ MOUSSALEM, Tárek Moysés. As fontes do direito tributário. São Paulo: Max Limonad, 2001. p. 92.

${ }^{25}$ KELSEN, Hans. Teoria Pura do Direito. Tradução de João Baptista Machado. São Paulo: Martins Fontes, 1991, p. 260.

${ }^{26}$ TOMÉ, Fabiana Del Padre. A prova no direito tributário. São Paulo: Noeses, 2005, p. 32.
} 
Embora o caminho natural seja buscar cada incidência no caso mais individualizado possível, muitas vezes na ânsia pela simplificação ou pela impossibilidade prática da incidência individualizada, o aplicador irá adotar um caminho inverso ao da positivação do direito, criando abstrações que permitam abarcar um maior número de eventos do mundo social, muitas vezes não representativos da vontade do legislador.

Verificar se tal procedimento é válido, quais os limites e em que situações será possível, é o desafio que se nos apresenta.

Um dos exemplos mais visíveis desta simplificação ocorre com o imposto predial, territorial e urbano - IPTU. Como a norma tributária determina que a base de cálculo para apuração do montante de imposto a pagar é o valor venal, o qual depende de uma avaliação individualizada de cada imóvel, “cabe ao Executivo estabelecer normas e critérios genéricos de procedimentos tendentes a apurá-lo ou, até mesmo, determinar que os próprios agentes fiscais avaliem cada imóvel individualmente, obedecidas algumas regras ou métodos da técnica avaliativa". ${ }^{27}$

Em razão da impossibilidade prática da administração realizar uma investigação exaustiva em cada caso isolado para aplicação individualizada da norma, o executivo edita mapas ou plantas genéricas de valores para determinar "os valores médios unitários de metro quadrado (ou linear) de terreno e de construção, originários ou corrigidos, acompanhados de regras e métodos, genéricos ou específicos, para apuração do valor venal de imóveis". ${ }^{28}$

Essa padronização pela média não é o objetivo da norma, mas para que fosse factível sua aplicação, foi necessária essa simplificação da lei, tendo como consequência que a fixação de valores por uma presunção do que é médio, invariavelmente trará a desconsideração de um número considerável de diferenças individualmente consideradas em cada caso concreto.

Por seus reflexos positivos, AIRES F. BARRETO pondera ser aconselhável a edição desses mapas genéricos de valores, uma vez que, "facilita e racionaliza o trabalho, resguarda a necessária uniformidade no comportamento do Fisco, evita discrepâncias próprias do arbítrio e representa segurança para o Fisco e os contribuintes". ${ }^{29}$

Por outro lado, MisABEL DERZI pondera os aspectos negativos dessa uniformidade e simplificação trazidas pelas plantas de valores genéricos ao enunciar que: "são incompatíveis com a finalidade de justiça fiscal individual, legalmente almejada. Tributar cada um segundo a

\footnotetext{
${ }^{27}$ BARRETO, Aires Fernandino. Curso de Direito Tributário Municipal. São Paulo: Saraiva, 2009, p. 225.

${ }^{28}$ BARRETO, Aires Fernandino. Curso de Direito Tributário Municipal. São Paulo: Saraiva, 2009, p. 227.

${ }^{29}$ BARRETO, Aires Fernandino. Curso de Direito Tributário Municipal. São Paulo: Saraiva, 2009, p. 227.
} 
sua capacidade contributiva (a qual varia de propriedade a propriedade imobiliária) e na proporção de sua desigualdade é a meta legal". ${ }^{30}$

Essas normas simplificadoras, utilizadas por razões de viabilidade prática, esbarram nos limites materiais determinados pelo princípio da igualdade e seu corolário o princípio da capacidade contributiva, por assumir na aplicação da lei uma igualdade formal em situações reais de desigualdade.

A massificação resultante da aplicação dessa norma simplificadora também afronta os limites formais, em especial, ao atenuar a tipicidade ou determinabilidade implícitas no princípio da legalidade.

Estudar até que ponto essas simplificações trazidas pela praticabilidade exigida na aplicação individual das leis podem ser ponderadas com os limites e garantias constitucionais é a missão que buscaremos enfrentar.

\subsubsection{Normas Simplificadoras como espécie das Normas Tributárias}

GERD WILli ROTHMANN ${ }^{31}$, apoiado na doutrina de TIPKE, classifica as normas tributárias, conforme sua finalidade, em três grupos: (i) normas de finalidade fiscal; (ii) normas de finalidade social; e (iii) normas de simplificação.

As normas de finalidade fiscal constituem-se na principal fonte do Estado para poder atender às necessidades públicas e da justiça distributiva, sendo considerada a capacidade contributiva, "o princípio fundamental para todos os impostos de função fiscal, mas não de função extrafiscal, indutora". ${ }^{32}$

O grupo das normas de finalidade social (extrafiscal ou indutora) tem por finalidade precípua atender a demandas da política social (inclusive redistribuição de renda), econômica, cultural etc. Como se baseiam no poder de tributar, essas normas se enquadram no regime jurídico dos tributos e "consequentemente, a intepretação das leis 'extrafiscais' obedece aos mesmos princípios das demais normas tributárias". ${ }^{33}$

\footnotetext{
${ }^{30}$ DERZI, Misabel de Abreu Machado. Direito tributário, direito penal e tipo, 2. ed. São Paulo: Revista dos Tribunais, 2008, p. 349

${ }^{31}$ ROTHMANN, Gerd Willi. Tributação, Sonegação e Livre Concorrência. In FERRAZ, Roberto (coord.). Princípios e limites da tributação 2 - Os princípios da ordem econômica e a tributação. São Paulo: Quartier Latin, 2009. p. 335 e ss.

${ }^{32}$ ROTHMANN, Gerd Willi. Tributação, Sonegação e Livre Concorrência. In FERRAZ, Roberto (coord.). Princípios e limites da tributação 2 - Os princípios da ordem econômica e a tributação. São Paulo: Quartier Latin, 2009. p.336.

${ }^{33}$ Ibidem, p. 338-339.
} 
Porém o professor ressalta que por sua natureza e finalidade não são aplicáveis a essas normas alguns princípios constitucionais ${ }^{34}$, como por exemplo os princípios da capacidade contributiva e anterioridade entre outros.

As normas de simplificação são aquelas que "visam facilitar e simplificar a aplicação do direito tributário, estruturando-o de forma mais praticável ou econômica". ${ }^{35}$

O professor observa que as normas de simplificação por tratarem desigualmente os contribuintes, precisam de uma "justificação para poderem ser utilizadas em um sistema tributário que se baseia na distribuição uniforme do ônus fiscal e na capacidade contributiva. Assim, por exemplo, o princípio da praticabilidade pode exigir, em determinados casos, uma ponderação com o princípio da capacidade contributiva" (grifo nosso). ${ }^{36}$

KLAus Vogel, citado por Luís EdUARDo SCHOUERI ${ }^{37}$, observou que "no processo de interpretação de uma norma jurídica, sua finalidade não se busca apenas por critérios subjetivos ou objetivos, mas pela vontade objetivada, i.e., expressa na lei, cabendo ao intérprete buscar o pensamento do legislador, até o ponto que isso for possível" e quando isto não for possível "deve o intérprete valer-se de outro critério para a determinação de sua finalidade: a função".

Segundo VogEL todas as normas prescritivas de impostos possuem a função (positiva ou negativa) de arrecadar (Ertragsfunktion), mas ao mesmo tempo poderão ter outras três funções, nem sempre presentes simultaneamente: “i) a função de distribuir a carga tributária (Lasenausteilungsfunktion), que implica a repartição das necessidades financeiras do Estado segundo os critérios de justiça distributiva; ii) função indutora; e iii) função simplificadora". ${ }^{38}$

LUÍs EDUARDO SCHOUERI ressalta um mérito importantíssimo na análise de VoGEL, quando não opõe as outras funções à função arrecadadora, reconhecendo que a análise pragmática, partindo de critérios funcionais, proposta pelo doutrinador alemão, "permite que uma mesma norma tributária desempenhe mais de uma função". ${ }^{39}$

De maneira análoga ao professor SCHOUERI, que fez as análises acima citadas para as normas indutoras, podemos dizer que a identificação das normas simplificadoras, por

\footnotetext{
${ }^{34}$ LUÍS EDUARDO SCHOUERI conclui que as limitações constitucionais ao poder de tributar nas normas indutoras, podem assumir novo viés, quando a elas se agregam forças dos princípios desenvolvidos na Ordem Econômica (SCHOUERI, Luís Eduardo. Normas Tributárias Indutoras e Intervenção Econômica. Rio de Janeiro: Forense, 2005, p. 231).

${ }^{35}$ ROTHMANN, Gerd Willi. Tributação, Sonegação e Livre Concorrência. In FERRAZ, Roberto (coord.). Princípios e limites da tributação 2 - Os princípios da ordem econômica e a tributação. São Paulo: Quartier Latin, 2009. p. 340.

${ }^{36}$ Ibidem, p. 340.

${ }^{37}$ SCHOUERI, Luís Eduardo. Normas Tributárias Indutoras e Intervenção Econômica. Rio de Janeiro: Forense, 2005, p. 27.

${ }^{38}$ SCHOUERI, Luís Eduardo. Normas Tributárias Indutoras e Intervenção Econômica. Rio de Janeiro: Forense, 2005, p. 27

${ }^{39}$ Ibidem, p. 29.
} 
intermédio de um corte metodológico que isole a função simplificadora, não é tarefa fácil, visto que as demais funções não se excluem e frequentemente estão presentes numa mesma norma.

Se analisarmos, em apertada síntese, a norma que instituiu o regime do Simples Nacional, podemos, por óbvio, dizer aprioristicamente que se trata de uma norma simplificadora ao verificarmos que sua função primordial é simplificar o recolhimento de vários tributos para determinadas pessoas jurídicas. Mas será que essa norma não tem a função de induzir as pessoas a regularizar suas atividades e sair do mercado informal de trabalho? Será que constituindo-se em contribuintes regulares e começarem a recolher tributos, não se estará atendendo a função de arrecadar e distribuir a carga tributária?

Humberto ÁviLA"40 aponta também como finalidades das leis tributárias: "repartir equanimente a carga tributária; atingir um finalidade econômica ou social; ou simplificar a arrecadação" e conclui que tais finalidades "podem andar juntas, mas não necessariamente".

Como ilustração ele descreve a possibilidade do legislador instituir o imposto de renda com as três finalidades: (i) obter receita, repartindo igualmente a carga tributária entre os contribuintes que tiverem a mesma capacidade contributiva verificada individualmente; (ii) com o propósito de fomentar o desenvolvimento de uma região, o que justificará o afastamento do princípio da capacidade contributiva; e (iii) simplificar a arrecadação utilizando padrões de isenções e de despesas dedutíveis, representativo da média das operações praticadas pelos contribuintes, tratando os casos conforme o princípio da igualdade geral.

As normas simplificadoras, conclui, ao mesmo tempo em que possibilitam simplificar a arrecadação, servem de meio para realizar a igualdade da carga tributária no processo de aplicação em massa da tributação.

\subsubsection{Normas Simplificadoras e a Extrafiscalidade}

A extrafiscalidade engloba todas as demais funções da norma tributária distintas daquelas relativas à arrecadação de tributos. Conforme aponta Luís EDUARDO SCHOUERI: “é imediato que ali se incluirá, por exemplo, a função de mera simplificação do sistema tributário". ${ }^{41}$

\footnotetext{
40 ÁVILA, Humberto. Imposto sobre a circulação de mercadorias: ICMS; substituição tributária; base de cálculo; pauta fiscal; preço máximo ao consumidor; diferença constante entre o preço usualmente praticado e o preço constante da pauta ou o preço máximo ao consumidor sugerido pelo fabricante; exame de constitucionalidade. Revista Dialética de Direito Tributário, n.123. São Paulo: Dialética, 2005, p. 125-126.

${ }^{41}$ SCHOUERI, Luís Eduardo. Normas Tributárias Indutoras e Intervenção Econômica. Rio de Janeiro: Forense, 2005 , p.32.
} 
A função simplificadora, segundo o professor, é "uma função das normas tributárias regida pelo princípio da praticabilidade, autorizando o aplicador da lei a adotar medidas globais, generalizantes, com a finalidade de simplificar o sistema tributário". ${ }^{42}$

No seu entender a extrafiscalidade pode-se referir a um gênero e a uma espécie. No gênero estarão incluídos "todos os casos não vinculados nem à distribuição equitativa da carga tributária, nem à simplificação do sistema tributário" ${ }^{43}$, ou seja, as normas com função indutora e "outras que também se movem por razões não fiscais, mas desvinculadas da busca do impulsionamento econômico por parte do Estado". ${ }^{44}$

A extrafiscalidade no sentido estrito, ou seja, na espécie do gênero é nos dizeres de GERD ROTHMANN: “aplicação das leis tributárias visando precipuamente a modificação do comportamento dos cidadãos, sem considerar seu rendimento fiscal" ${ }_{45}$

Para PAUlo DE BARros CARVAlHo a fiscalidade e a extrafiscalidade são construções puramente doutrinárias, constituindo-se fator de identificação do modo de utilização da norma tributária.

A fiscalidade, nas suas palavras, é revelada quando "a organização jurídica do tributo denuncie que os objetivos que presidiram sua instituição, ou que governam certos aspectos da sua estrutura, estejam voltados ao fim exclusivo de abastecer os cofres públicos, sem que outros interesses - sociais, políticos ou econômicos - interfiram no direcionamento da atividade impositiva". ${ }^{46}$

A extrafiscalidade ocorre quando o modo de utilização do instrumental jurídicotributário, "persegue objetivos alheios aos meramente arrecadatórios". ${ }^{47}$

Mas, adverte: "Não existe, porém, entidade tributária que se possa dizer pura, no sentido de realizar tão-só a fiscalidade, ou, unicamente, a extrafiscalidade"48. E, ainda mais importante, o professor ressalta que o regime a ser utilizado na extrafiscalidade deve ser o mesmo utilizado nas normas tributárias, o que implica dizer que o legislador deverá, ao construir suas pretensões fiscais: "pautar-se, inteiramente, dentro dos parâmetros constitucionais, observando as limitações de sua competência impositiva e os princípios superiores que regem a matéria, assim expressos que os implícitos”. ${ }^{49}$

\footnotetext{
${ }^{42}$ SCHOUERI, Luís Eduardo. Normas Tributárias Indutoras e Intervenção Econômica. Rio de Janeiro: Forense, 2005, p.32.

${ }^{43}$ Ibidem, p. 32.

${ }^{44}$ Ibidem, p. 32.

${ }^{45}$ ROTHMANN, Gerd Willi. Tributação, Sonegação e Livre Concorrência. In FERRAZ, Roberto (coord.). Princípios e limites da tributação 2 - Os princípios da ordem econômica e a tributação. São Paulo: Quartier Latin, 2009. p. 338.

${ }^{46}$ CARVALHO, Paulo de Barros. Curso de Direito Tributário. 17. ed. São Paulo: Saraiva, 2005. p. 234.

${ }^{47}$ CARVALHO, Paulo de Barros. Curso de Direito Tributário. 17. ed. São Paulo: Saraiva, 2005. p. 235.

${ }^{48}$ Ibidem, p. 236.

${ }^{49}$ Ibidem, p. 236.
} 
Com tese contrária, Douglas YAMASHITA advoga que: "a distinção entre normas de finalidade fiscal e normas de finalidade extrafiscal é fundamental para determinar o regime jurídico de cada norma, pois é a partir daí que saberemos quais os princípios constitucionais aplicáveis" ${ }_{50}$.

Segundo o jurista, como a capacidade contributiva foi escolhida pela nossa ordem constitucional (art. 145, $\S 1^{\circ}$. da $\mathrm{CF} / 88$ ) como o critério de comparação para a realização do princípio da igualdade na tributação, a distinção entre as normas fiscais e extrafiscais é verificada pela obediência ou não da capacidade contributiva:

Assim, juntamente com Tipke entendemos que uma norma de alguma forma justificável com ponderações de capacidade contributiva é assim uma norma de finalidade fiscal, ainda que o legislador acreditasse seguir finalidades extrafiscais. Por conseguinte, norma de finalidade extrafiscal é aquela que de nenhuma forma se deixa justificar com ponderações de capacidade contributiva ${ }^{51}$.

Neste mesmo sentido, Humberto Ávila entende que ficções e presunções utilizadas nas normas simplificadoras a serviço da praticabilidade "afastam-se do dever constitucional de observância da igualdade segundo a capacidade contributiva em função de uma finalidade extrafiscal qualquer, normalmente econômica ou social". ${ }^{2}$

Entendemos correto afirmar que as normas simplificadoras, ainda quando não tenham a função precípua de melhorar a arrecadação, tratam da tributação e estão, portanto, sujeitas a princípios e normas gerais do sistema jurídico tributário.

Isso não quer dizer que os princípios deverão ser aplicados com o mesmo peso relativo tanto no caso de uma norma com finalidade fiscal, como no caso de uma norma que busque outras finalidades que não a arrecadação de receitas, como por exemplo atender uma necessidade prática da administração.

A finalidade extrafiscal torna-se relevante para justamente permitir uma ponderação $0^{53}$ dos valores protegidos pelos princípios em conflito, como veremos mais adiante.

\footnotetext{
${ }^{50}$ YAMASHITA, Douglas. Confisco como efeito tributário e sua proibição constitucional. Repertório IOB de Jurisprudência. Belo Horizonte, n. 10, p. 259, 2a. quinzena, maio. 2000. Caderno 1.

${ }^{51}$ YAMASHITA, Douglas. Confisco como efeito tributário e sua proibição constitucional. Repertório IOB de Jurisprudência. Belo Horizonte, n. 10, p. 260, 2a. quinzena, maio. 2000. Caderno 1.

${ }_{52}$ ÁVILA, Humberto. Teoria da Igualdade Tributária. 2a . edição. São Paulo: Malheiros, 2009, p. 83. De opinião contrária: "Mesmo a tributação extrafiscal deve respeitar o princípio de capacidade contributiva no sentido de que, ainda que sendo preordenada a metas extrafiscais, e mesmo sendo estas metas alcançadas exatamente quando a hipótese de incidência não se verifica, a tributação deve ter como pressuposto um fato economicamente relevante, um fato que constitua manifestação de riqueza”. DE MITA, Enrico. O Princípio da Capacidade Contributiva. In FERRAZ, Roberto (coord.). Princípios e Limites da Tributação. São Paulo: Quartier Latin, 2005, p. 248.

${ }^{53}$ Segundo a doutrina: "Princípios são normas que ordenam que algo seja realizado em uma medida tão ampla quanto possível relativamente a possibilidades fáticas ou jurídicas Princípios são, portanto, mandamentos de otimização. Como tais, eles podem ser preenchidos em graus distintos. A medida ordenada do cumprimento depende não só das possibilidades fáticas, senão também das jurídicas. Estas são determinadas, ao lado, por regras, essencialmente por princípios opostos. As colisões de direitos fundamentais supra delineadas devem, segundo a teoria dos princípios, ser qualificadas de colisões de princípios. $\mathrm{O}$
} 
Com ela surge um novo balanço de forças, no qual os princípios da proporcionalidade e a razoabilidade serão aplicados em consonância com os demais, resultando na realização da justiça no caso concreto.

procedimento para a solução de colisões de princípios é a ponderação". ALEXY, Robert. Colisão de direitos fundamentais e realização de direitos fundamentais no Estado de Direito Democrático. Revista de Direito Administrativo, v. 217. Rio de Janeiro: Renovar, 1999, p. 74-75. 


\section{Tributação e Praticabilidade}

\subsection{Demandas pela Simplificação}

A sociedade contemporânea é extremamente complexa em razão das infinitas possibilidades da realidade. Para NIKLAS LUHMANN ${ }^{1}$ a complexidade é razão de existirem mais possibilidades do que aquelas que se pode realizar, tornando-se o objetivo das Ciências, em especial do Direito, atuar como redutor dessa complexidade.

O direito positivo necessariamente deve reduzir as complexidades da realidade social, descartando traços irrelevantes, pois caso contrário, o legislador não conseguiria produzir o fato jurídico.

Conforme PAUlo de Barros CARVAlho, ${ }^{2}$ "uma metalinguagem é sempre redutora da linguagem-objeto de que se ocupa", "e cumprindo a tarefa de qualificar normativamente situações da vida social, o direito não poderia escapar desse princípio axiomático".

As novas circunstâncias, reflexo da economia cada vez mais globalizada e da explosão demográfica, fizeram com que os sistemas tributários modernos evoluíssem, tornando-se cada vez mais complexos.

Essas modificações no direito, fruto de atualizações das autoridades legislativas é a forma de "acompanhar, a seu modo, a dinâmica e palpitante velocidade das mutações sociais, adaptando-se às novas circunstâncias e mantendo, por esse meio, íntegros seus objetivos finais"'.

A efetiva realização do princípio da capacidade econômica também é apontada como causa da complexidade tributária ${ }^{4}$. O legislador na ansiedade de querer medir a capacidade econômica individual, leva inexoravelmente à complexidade do sistema tributário.

Como corolário dessa crescente complexidade da legislação, houve um aumento no custo das obrigações acessórias (custos de conformidade), incremento da criminalidade

\footnotetext{
${ }^{1}$ LUHMANN, Niklas. Sociologia do Direito I. Rio de Janeiro: Templo Brasileiro, 1983, p. 45.

${ }^{2}$ CARVALHO, Paulo de Barros. Fundamentos Jurídicos da Incidência Tributária. 8. ed.. São Paulo: Saraiva, 2010, p. 155149.

${ }^{3}$ CARVALHO, Paulo de Barros. Fundamentos Jurídicos da Incidência Tributária. 8. ed.. São Paulo: Saraiva, 2010, p. 156.

${ }^{4}$ NOVOA, César Garcia. Los métodos de simplificatión fiscal em la experiência latino americana. Referencia comparativa a los casos brasileno y argentino. Revista de Contabilidad y Tributación del Centro de Estudios Financieros, n. 59. Madri, outubro/2003, p. 69. No seu entender : "la complejidad de los sistemas tributários modernos es uma realidade inherente al desarrollo del principio constitucional de capacidade económica y a las dificultades técnicas para su aplicación, especialmente em tanto se siga identificando la realización de la capacidade económica com la necesidad de individualizar siempre y de modo pormenorizado dicha capacidade subjetiva".
} 
estruturada, por intermédio da sonegação e planejamento fiscal abusivo, além de a impossibilidade física da administração aplicar individualmente em cada caso concreto a norma tributária.

Muitas vezes a administração se encontra em uma situação tal, que a execução individualizada da lei ultrapassa suas forças ou o uso racional dos seus meios, na situação denominada de "estado de necessidade"s. Muitas vezes, como ocorre, por exemplo com o ISS em vários munícipios brasileiros, quando o custo para implementar a arrecadação suplanta o valor arrecadado, a administração faz a opção de abrir mão da receita deste tributo, pela simples incapacidade de aplicação da lei.

Nestas situações, em razão dos altos custos operacionais para realizar a diferenciação e individualização, ocorre a "edição de normas de simplificação, seja em sede legislativa, seja em sede administrativa, através das quais se proceda à tipificação (ou tipi(ci)zação, globalização (Pauschlierung) ou estandardização"6.

Essa tipificação, ou modo de pensar tipificante ${ }^{7}$, assume como regra o que é típico (normal, geral, médio) desprezando as diferenças individuais que uma tributação comprometida com a capacidade contributiva proporciona.

Como analisaremos em tópico futuro a tributação deixou de constituir-se simplesmente em fonte de receita, mas revelou-se no Estado Democrático de Direito como um instrumento de realização de justiça, ao perquirir a igualdade material e não apenas formal, com a redistribuição de riquezas.

A simplificação surge, então, como necessidade de garantir essa melhor eficiência da arrecadação, tanto no âmbito legislativo como administrativo.

A averiguação de cada caso individualmente considerado e o levantamento de provas, muitas vezes difíceis de se obter, demandariam a manutenção de recursos humanos e materiais de custos exorbitantes e provavelmente inviáveis do ponto de vista de uma arrecadação eficiente.

\footnotetext{
${ }^{5}$ CABAIS, José Casalta. O Dever Fundamental de Pagar Impostos - Contributo para a compreensão constitucional do estado fiscal contemporâneo. 3. ed. Coimbra: Almedina, 2012, p. 336.

${ }^{6}$ Ibidem, p. 375.

${ }^{7}$ Misabel Derzi adverte que esse modo de pensar foi impropriamente chamado de "tipificante" pois sua associação com a ideia de tipo não foi adotada no sentido técnico-jurídico do tipo, mas na acepção comum de esquema, generalização, que desconsidera as diferenças individuais. DERZI, Misabel de Abreu Machado. Direito tributário, direito penal e tipo, 2. ed. São Paulo: Revista dos Tribunais, 2008, p. 319. Segundo a autora: "o chamado modo de raciocinar tipificante não cria tipos propriamente ditos como ordens de estrutura flexível e aberta. A inadequação do nome se deve ao fato de que a Administração procura lançar o tributo, segundo o padrão médio social, partindo de uma abstração generalizante, mas fecha-o através de quantificação que despreza as diferenças individuais, as exceções, os casos-limite”, p. 141-142.
} 
Essa desproporção entre o encargo da administração fazendária e a respectiva capacidade para gerir e fiscalizar os tributos é apontada pela doutrina ${ }^{8}$ com um estado de necessidade administrativo, constituindo-se em uma das justificações para a praticabilidade.

As razões apontadas ${ }^{9}$ para essa desproporção são: (i) supercomplexidade e ausência de sistema no direito tributário; (ii) falta de praticidade da lei fiscal; (iii) inadaptabilidade da lei tributária às mutações sociais e econômicas; e (iv) falta de pessoal.

MisAbel DeRZI ${ }^{10}$, apoiada nas lições de IsENSEE, aponta o dilema entre legalidade e praticabilidade, que surge em razão deste estado de necessidade administrativo:

Se cada fato tributário for esclarecido, exaustivamente, com o mesmo cuidado que se requer no Direito Penal, p. ex., o custo do aparato administrativo necessário será superior à arrecadação e, o que é mais significativo, a maioria dos casos sujeitos a lançamento ficará sem atendimento. Se, ao contrário, cada fato não for verificado em pormenor, o programa da norma legal será descumprido, será ferido o princípio da justiça tributária e o da individualidade do tratamento do caso isolado.

Nas palavras de ReginA HelenA CostA"1: "Tornar mais simples os sistemas tributários constitui, mesmo, um dos grandes objetivos da fiscalidade de nossos dias, já que, por razões várias, os ordenamentos fiscais se têm convertido em realidades cada vez mais complexas".

KLAUS TIPKE ${ }^{12}$ aponta que o caos tributário (Tax chaos) hoje instalado e lamentado por grande parte das democracias ocidentais, fez surgir um movimento de reinvindicação pela adoção de normas simplificadoras, ao que denominou de tax simplification.

O jurista germânico, citando KLAUS VoGEL, registra que desde a primeira guerra mundial, o direito tributário, pelo sem número de alterações e complementações, em razão de exceções e novamente por exceções a essas exceções, se converteu em um ramo jurídico de difícil compreensão tanto pelo leigo, quanto para os especialistas, razão pela qual o descrevem como "caos", "selva" ou até mesmo "perversão"13.

Cesar NovoA ${ }^{14}$ chega a afirmar, com base em MANCur Olson, que essa complexidade é deliberadamente buscada: pelos técnicos e experts em direito tributário; pelos

\footnotetext{
${ }^{8}$ DERZI, Misabel de Abreu Machado. Direito tributário, direito penal e tipo, 2. ed. São Paulo: Revista dos Tribunais, 2008, p. 3338-339.

${ }^{9}$ Ibidem, p. 338-339.

${ }^{10}$ Ibidem, p.339.

${ }^{11}$ COSTA, Regina Helena. Praticabilidade e justiça tributária - Exequibilidade de Lei Tributária e Direitos do Contribuinte. São Paulo: Malheiros, 2007, p. 19.

12 TIPKE, Klaus; YAMASHITA, Douglas. Justiça Fiscal e Princípio da Capacidade Contributiva, p. 76.

${ }^{13}$ Ibidem, p. 74.

${ }^{14}$ NOVOA, César Garcia. Los métodos de simplificatión fiscal em la experiência latino americana. Referencia comparativa a los casos brasileno y argentino. Revista de Contabilidad y Tributación del Centro de Estudios Financieros, n. 59. Madri, outubro/2003, p. 69. No original: "uma complejidade deliberadamente buscada, que beneficia a los técnicos y expertos de Derecho Tributario y a los contribuyentes que pueden pagárselos, y que a la vez permite, a los políticos y burocratas sacar partido de esa complejidad voluntariamente buscada, outorgando dispensas de tributación a través de benefícios fiscales que son perseguidos por los grupos de presión".
} 
contribuintes que podem pagar a esses técnicos; e, também, pelos políticos e burocratas que podem tirar partido dessa complexidade deliberadamente buscada, outorgando a dispensa de tributação para determinados grupos de pressão, via benefícios fiscais.

TIPKE utiliza a expressão imposto para tolos $^{15}$, reportando-se ao fato de que, com a complexidade, as empresas melhores estruturadas financeiramente conseguem, por intermédio de uma dispendiosa consultoria tributária, reduzir legalmente sua carga tributária, enquanto os demais, por não disporem dessa assessoria, são obrigados a pagar integralmente os tributos.

De 1988 a 2005 a nossa legislação tributária teve nada menos do que 3,4 milhões de normas editadas ${ }^{16}$ e segundo um estudo do banco mundial, denominado Paying Taxes, de 2008, o tempo gasto para uma empresa pagar os impostos no Brasil era de 2.600 horas, o pior resultado em todo o mundo, ficando atrás dos Emirados Árabes com 12 horas, Suíça com 63 horas e Venezuela com 864 horas.

Podemos então destacar que as principais demandas pela simplificação das leis tributárias ocorrem: pela incapacidade administrativa de aplicá-las a milhares de casos, que se multiplicam em função da explosão demográfica; pela complexidade da legislação em razão das sofisticadas técnicas de tributação; e pelo imperativo de melhoria da eficiência na arrecadação.

Surge desta forma a praticabilidade como forma de designar todos os meios destinados a facilitar e simplificar a execução das leis.

\subsection{Praticabilidade}

Define-se Praticabilidade ou Praticidade como "qualidade ou característica do que é praticável” e praticável como aquilo “que pode ser praticado; factível, exequível, realizável”. ${ }^{17}$

Em razão de sua abstração e generalidade, não é possível ao direito regular as condutas intersubjetivas utilizando-se de normas gerais e abstratas. Para tanto, o sistema do direito carece de uma norma individual e concreta para um caso materialmente definido.

Ocorrendo a subsunção da hipótese prevista na norma geral e abstrata com o fato da realidade social, por intermédio do processo de positivação, no ato da aplicação, acontece a

\footnotetext{
15 TIPKE, Klaus. Moral Tributária do Estado e dos Contribuintes. Tradução: Luiz Dória Furquim. Porto Alegre: Sergio Antonio Fabris, 2012, p. 74.

${ }^{16}$ ABDENUR, Roberto. A boa notícia, um alerta e os impostos. Disponível em: $<$ http://www.estadao.com.br/noticias/impresso,a-boa-noticia-um-alerta-e-os-impostos-,904062,0.htm>.Acesso em: 23 julho 2012. Segundo o autor: "Essa demora na simplificação e racionalização do sistema tributário tem sido um dos maiores obstáculos à modernização da economia brasileira".

17 Grande Dicionário Houaiss da Língua Portuguesa. Disponível em: < http://houaiss.uol.com.br/busca?palavra=praticabilidade>. Acesso em 27 de maio de 2013.
} 
passagem da abstração e generalidade para a concretude e individualidade das normas jurídicas. ${ }^{18}$

Com a hipercomplexidade da sociedade moderna, as previsões hipotéticas das normas gerais e abstratas tributárias devem abranger cada vez mais fatos econômicos da realidade, que se multiplicam em uma velocidade compatível com o ritmo frenético dos dias atuais.

A solução para essa realidade seria a edição de novas normas gerais e abstratas a cada surgimento de um fato econômico que não se encaixa perfeitamente com previsão normativa?

Entendemos que não! Por um bom tempo e ainda hoje o legislativo, impulsionado pelas demandas da administração fazendária, criou nosso "caos tributário" com a edição desmedida de emendas complementares, leis gerais, leis especiais, decretos, portarias, na ingênua ideia de que seria possível uma abrangência normativa total para a infinidade da realidade social.

Para que seja possível a tributação em massa, de modo célere e menos oneroso, surge a praticabilidade como "um nome amplo genérico, e significa apenas um nome para designar todos os meios, todas as técnicas usadas para possibilitar a execução e a aplicação das leis. Sem execução e sem aplicação, as leis não têm sentido; elas são feitas para serem obedecidas". ${ }^{19}$

A praticabilidade surge então com essa necessidade de possibilitar a aplicação da norma tributária em massa o que ocorre a partir da profusão de fatos econômicos cada vez mais dinâmicos e complexos, tendo como marco inicial a formação do estado moderno.

Antes do surgimento do estado moderno havia uma pluralidade de fontes normativas, na medida em que cada comunidade ou feudo produzia seu próprio direito, isto é, o direito era mais próximo da realidade social, das condutas a serem reguladas..$^{20}$

A partir da revolução francesa e a formação do Estado moderno operou-se a centralização normativa nas mãos do estado, com o direito passando a ser aquilo que o estado dizia ser e, não mais, como aquilo que era racional por quem doutrinava e aplicava o direito.

\footnotetext{
${ }^{18}$ MOUSSALEM, Tárek Moysés. As fontes do direito tributário. São Paulo: Max Limonad, 2001. p. 91.

${ }^{19}$ DERZI, Misabel de Abreu Machado. Princípio da praticabilidade do direito tributário - segurança jurídica e tributação. Revista de Direito Tributário, São Paulo: Revista dos Tribunais, v. 13, n. 47, p. 175-176, jan.-mar. 1989.

${ }^{20}$ PONTES, Helenílson Cunha. O princípio da praticidade no Direito Tributário (substituição tributária, plantas de valores, retenções de fontes, presunções e ficções, etc): sua necessidade e seus limites. Revista Internacional de Direito Tributário, v.2.Minas Gerais: Del Rey, julho/dezembro de 2004, p. 53 e ss.
} 
Como essa mudança de paradigma pela centralização da racionalidade, que ocorreu no momento em que o direito passou a ser não mais um produto do juízo racional, mas sim um produto da autoridade, acredita-se no mito positivista de que a lei "é um comando geral e abstrato que regula todas condutas, e que somente por isso é que permite-se a igualdade entre os seres humanos, e a igualdade na relação entre o estado e o indivíduo". ${ }^{21}$

Essa lógica de aplicação uniforme da norma geral e abstrata, fruto da ideia de identificação do direito com a razão do legislador, foi concebida em uma sociedade estratificada e com interesses bem definidos do século XVIII (burguesia, clero e nobreza).

Com a complexidade de nossa sociedade atual marcada pela profusão e difusão de interesses não se concebe mais essa ideia mítica de aplicação uniforme de uma lei geral e abstrata. A norma jurídica cada vez mais se afasta da realidade que pretende regular.

O direito, em especial o direito tributário, precisa lidar com essa transformação da realidade: "se os fenômenos da realidade são complexos, é preciso que o direito tributário trate desses fenômenos com essa complexidade, reduzindo-os a um denominador comum". ${ }^{22}$

O direito tributário como qualquer outro direito só será eficaz se puder ser aplicável, isto é, se tiver normatividade sobre os fatos da vida real.

AlFREDo Augusto BECKER ${ }^{23}$ enfatiza que o direito positivo "não é uma realidade metafísica existindo em si e por si", mas a regra jurídica é antes de tudo "um instrumento de convivência social”. Em suas palavras: "a regra jurídica somente existe (com natureza jurídica) na medida de sua praticabilidade" (grifo nosso).

O reconhecimento de que há um intervalo entre a realidade social e a realidade jurídica foi bem percebido por PAULO DE BARROS CARVALHO, que afirma que "o espaço que se entrepõe é inevitável” ${ }^{24}$, uma vez que o legislador elege quais "os aspectos do suporte físico que ingressam e quais os que não ingressam (ficando irrelevantes) nos domínios do direito". ${ }^{25}$

Segundo o professor, saber até que ponto a realidade jurídica pode se manter afastada da realidade social é tema que interessa não só à Sociologia Jurídica, à Ciência Política do Direito, à Filosofia do Direito, mas, principalmente, à própria Dogmática ou Ciência do Direito, "na medida em que diz respeito ao bom funcionamento do sistema, à sua eficácia como corpo de regras. Um ordenamento que não preveja certas situações, que contemple

\footnotetext{
${ }^{21}$ PONTES, Helenílson Cunha. O princípio da praticidade no Direito Tributário (substituição tributária, plantas de valores, retenções de fontes, presunções e ficções, etc): sua necessidade e seus limites. Revista Internacional de Direito Tributário, v.2.Minas Gerais: Del Rey, julho/dezembro de 2004, p. 54.

${ }^{22}$ Ibidem, p. 55.

${ }^{23}$ BECKER, Alfredo Augusto. Teoria Geral do Direito Tributário. 5.ed.São Paulo: Noeses, 2010, p. 74-75.

${ }^{24}$ CARVALHO, Paulo de Barros. Fundamentos Jurídicos da Incidência Tributária. 8. ed.. São Paulo: Saraiva, 2010, p. 155156.

${ }^{25}$ Ibidem, p. 155-156.
} 
insuficientemente os fatos sociais, não pode pretender realizar os valores que se propõe”. ${ }^{26}$ (grifo nosso).

A razão da praticabilidade é permitir a efetividade da norma tributária na aplicação em massa própria do direito tributário. É a criação de mecanismos de simplificação e padronização que permita a efetividade da norma tributária. ${ }^{27}$

A praticabilidade ao aproximar a norma jurídica da realidade que pretende regular torna o direito exequível. ${ }^{28}$

Como define ISENSEE: "Praticidade é o nome que designa a totalidade das condições que garantem uma execução eficiente e econômica das leis". ${ }^{29}$

HANS ARNDT conceitua a praticabilidade como "el conjunto de médios y técnicas utilizables com ele objetivo de hacer simple y viable la ejecución de las leyes". ${ }^{30}$

No campo do direito tributário, as exigências pela praticidade são cada vez mais preeminentes, porque "o emperramento da máquina administrativa e judicial do Estado são desafios de difícil solução, cada vez mais acentuados em função de fatores como a explosão demográfica brasileira, a conscientização política-jurídica da população, o progresso e as formas e técnicas sofisticadas de tributação". ${ }^{31}$

Como as relações econômicas e sociais estão se tornando cada vez mais complexas, mais necessária se faz a aplicação maciça da lei, o que destaca esta especial aplicação da praticabilidade no campo da tributação: simplificar a execução da lei em massa. ${ }^{32}$

REGina Helena Costa também compartilha o entendimento de que a noção de praticabilidade é relevante para que a lei possa ser executada em massa, principalmente no campo tributário onde "tal circunstância é sentida em grande dimensão, haja vista a rápida e automática multiplicação das relações jurídico-tributárias. Com efeito, ostentando tais relações

\footnotetext{
${ }^{26}$ CARVALHO, Paulo de Barros. Fundamentos Jurídicos da Incidência Tributária. 8. ed.. São Paulo: Saraiva, 2010, p. 155156.

${ }^{27}$ PONTES, Helenílson Cunha. O princípio da praticidade no Direito Tributário (substituição tributária, plantas de valores, retenções de fontes, presunções e ficções, etc): sua necessidade e seus limites. Revista Internacional de Direito Tributário, v. 2. Minas Gerais: Del Rey, julho/dezembro de 2004, p. 57.

${ }^{28}$ MANEIRA, Eduardo. O princípio da praticidade no Direito Tributário (substituição tributária, plantas de valores, retenções de fontes, presunções e ficções, etc): sua necessidade e seus limites. Revista Internacional de Direito Tributário, v. 2. Minas Gerais: Del Rey, julho/dezembro de 2004, p. 62.

${ }^{29}$ Josef Isensee. Die Typsierende Verwaltung apud Misabel Derzi. Praticidade. ICMS. Substituição tributária progressiva, "para frente". In: Construindo o Direito Tributário na Constituição: uma análise da obra do Ministro Carlos Mário Velloso. Belo Horizonte: Del Rey, 2004, p. 177.

${ }^{30}$ Hans Wolfgang Arndt. Praktikabilitat und Effiziens apud César Garcia Novoa. "Los métodos de simplification en la experiência latino-americana" in Revista de Contabilidad y Tributación del Centro de Estudios Financeiros, p. 75.

${ }^{31}$ DERZI, Misabel De Abreu Machado. Direito tributário, direito penal e tipo, 2. ed. São Paulo: Revista dos Tribunais, 2008, p. 380.

32 Ibidem, p. 357.
} 
natureza ex lege, a praticabilidade encontra nelas campo fértil para disseminar amplamente seus efeitos". ${ }^{33}$

CASAlta NABAis ao analisar as dificuldades do legislador, em termos fiscais, para disciplinar um número enorme de situações aduz que justifica-se a utilização de técnicas de simplificação, como a generalização ou estandardização a fim de tornar o direito tributário praticável, "sendo-lhes, por conseguinte, permitido escolher, por razões de praticabilidade, bases forfaitaires, em vez dum critério ancorado da situação individual, satisfazendo-se assim com uma justiça tipificada (Typengerechtigkeit)". ${ }^{34}$

Tornar, deste modo, as normas tributárias praticáveis, viabilizando sua aplicação eficiente e econômica em massa, implica simplificá-las, i.e., desprezar diferenças individuais no atingimento das mais diversas e complexas manifestações da capacidade contributiva, com a execução simplificadora da lei que institui o tributo, trazendo um custo de arrecadação proporcional ao produto arrecadado.

Esse é o grande dilema por que passa o direito tributário: "como reduzir a complexidade da realidade a um denominador comum, ou a denominadores comuns, a conceitos comuns, a conceitos que sirvam a efetiva aplicação da norma tributária, sem ferir outros princípios informadores da justiça tributária?". ${ }^{35}$

No desenvolvimento deste estudo procuraremos enfrentar este dilema e quais os mais recentes posicionamentos doutrinários e jurisprudenciais.

\subsection{Praticabilidade como Princípio}

A praticabilidade como conjunto de mecanismos de simplificação e padronização que permitem a efetividade da norma tributária, traz consigo a desconsideração da real manifestação da capacidade contributiva, pondo-a em conflito com os demais princípios constitucionais.

Devemos, desta forma, tentar reconhecer na praticabilidade um caráter principiológico que permita ponderá-la com os demais princípios na resolução de conflitos, sob pena de tornar inconstitucional qualquer tentativa de sua utilização.

\footnotetext{
${ }^{33}$ COSTA, Regina Helena. Praticabilidade e justiça tributária - Exequibilidade de Lei Tributária e Direitos do Contribuinte, São Paulo: Malheiros, 2007, p. 89.

${ }^{34}$ CABAIS, José Casalta. O Dever Fundamental de Pagar Impostos - Contributo para a compreensão constitucional do estado fiscal contemporâneo. 3. ed. Coimbra: Almedina, 2012. p. 624.

${ }^{35}$ PONTES, Helenílson Cunha. O princípio da praticidade no Direito Tributário (substituição tributária, plantas de valores, retenções de fontes, presunções e ficções, etc): sua necessidade e seus limites. Revista Internacional de Direito Tributário, v.

2. Minas Gerais: Del Rey, julho/dezembro de 2004, p. 55.
} 
Princípio, como tantos outros vocábulos utilizados no discurso jurídico, experimenta inúmeras acepções, que variam de acordo com os valores adotados na sociedade e um dado intervalo de tempo. ${ }^{36}$

Como definição de princípio, não podemos deixar de citar a clássica lição de CELSO BANDEIRA DE MELLO:

Princípio é, pois, por definição mandamento nuclear do sistema, verdadeiro alicerce dele, disposição fundamental que se irradia sobre diferentes normas compondo lhes o espírito e servindo de crédito para sua exata compreensão e inteligência, exatamente por definir a lógica e a nacionalidade do sistema normativo, no que lhe confere a tônica e lhe dá sentido harmônico. É o conhecimento dos princípios que preside a intelecção das diferentes partes componentes do todo unitário que há por nome sistema jurídico positivo. ${ }^{37}$

ROQUE CARRAZZA entende ser o princípio jurídico um "enunciado lógico, implícito ou explícito que, por sua grande generalidade, ocupa posição de preeminência nos vastos quadrantes do Direito e, por isso mesmo, vincula, de modo inexorável, o entendimento e a aplicação das normas jurídicas que com ele se conectam". ${ }^{38}$

EROS GRAU ${ }^{39}$ entende ser inquestionável a existência em nosso ordenamento de princípios, que atuam fortemente no processo de interpretação/aplicação do direito e podem ser classificados em:"[i] princípios explícitos, recolhidos no texto da Constituição ou da lei; [ii] princípios implícitos, inferidos como resultado da análise de um ou mais preceitos constitucionais ou de uma lei ou conjunto de textos normativos da legislação infraconstitucional; e [iii] princípios gerais de direito, também implícitos, coletados no direito pressuposto, qual o da vedação do enriquecimento sem causa". ${ }^{40}$

Na doutrina do professor Helenílson CunHA PONTES ${ }^{41}$, a praticabilidade é um princípio que juntamente com os princípios da justiça tributária, da rentabilidade e da neutralidade formam a base da tributação moderna.

\footnotetext{
${ }^{36}$ CARVALHO, Paulo de Barros. Direito Tributário Linguagem e Método. 3. ed. São Paulo: Noeses, 2009, p. 252.

${ }^{37}$ MELLO, Celso Antônio Bandeira de. Curso de Direito Administrativo. 20. ed. São Paulo: Malheiros, 2006, p. $902-903$.

${ }^{38}$ CARRAZZA, Roque Antonio. Curso de Direito Constitucional Tributário. 22. Ed. São Paulo: Malheiros, 2006, p. 39.

${ }^{39}$ GRAU, Eros Roberto. A ordem econômica na Constituição de 1988. 14. ed. São Paulo: Malheiros, 2010. p. 154.

${ }^{40}$ Ibidem, p. 155.

${ }^{41}$ Segundo leciona: "A tributação moderna se apóia, basicamente, em quatro grandes princípios, ou comandos, ou máximas, qualquer que seja o nome que se dê. O primeiro, evidentemente (e se tiver que escalonar é o primeiro de sempre), é o princípio da justiça tributária. Nenhuma tributação, nenhuma norma jurídica há de se declarar, ou a de negar a intenção de se fazer justa. A justiça é um pressuposto inclusive do discurso normativo. A lei não precisa se dizer justa, ela é presumidamente justa. E aí da justiça, evidentemente, no direito tributário, nós temos como decorrência a igualdade, a capacidade contributiva, a segurança jurídica, etc. Um segundo princípio ou comando é o princípio da rentabilidade: nenhum tributo há de se fazer sobre uma base que não gere receita tributária. Os tributos hão de ter como base imponível fatos econômicos que conduzam a receita tributária; o princípio da rentabilidade é evidentemente um princípio informador da tributação. Há de serem tributados fatos que gerem receita tributária, o legislador não pode se ocupar de um fenômeno econômico que não gere nada. $\mathrm{O}$ terceiro comando é o princípio da neutralidade. O direito tributário também não pode criar mecanismos que impliquem em ofensa à eficiência econômica. Ou seja, o sistema econômico há de funcionar regularmente sem que o direito tributário seja um fenômeno de desconformidade do sistema econômico. E o último princípio ou comando é o princípio da praticabilidade, isto é, os comandos jurídicos hão de ter como pressuposto a possibilidade de serem cumpridos, cumpridos de uma forma razoável de uma forma racional. A simplicidade, portanto, e a praticabilidade por ela implicada, são pressupostos de qualquer norma tributária.
} 
Ele aponta ser um princípio informador próprio da ordem jurídica tributária, uma vez que todos os comandos jurídicos têm como pressuposto a possibilidade de serem cumpridos de uma forma razoável e de uma forma racional. "A simplicidade, portanto, e a praticabilidade por ela implicada, são pressupostos de qualquer norma tributária. Nenhuma norma tributária há de negar a sua praticabilidade, sob pena de ela se declarar ineficaz". ${ }^{42}$

A praticabilidade configura-se, no entendimento do mestre lusitano, JosÉ CASALTA NABAIS ${ }^{43}$, em um princípio polarizador das três máximas da tributação de ADAM SMITH: certeza, da comodidade e da economia.

RICARDO LOBO TORRES ${ }^{44}$ identifica a simplificação fiscal com um dos mais importantes princípios de legitimação do direito tributário, por garantir a afirmação da segurança jurídica e da justiça.

Para MisABEl DERZI não restam dúvidas: “A praticidade é um princípio geral e difuso, que não encontra formulação escrita nem no ordenamento jurídico alemão, nem no nacional. Mas está implícito, sem dúvida, por detrás das normas constitucionais" ${ }_{45}$ e, “como princípio geral de economicidade e exequibilidade, inspira o Direito de forma global". ${ }^{46}$

Para a professora DERZI esse princípio implícito por ter uma profunda relação com a efetividade das normas, ao garantir que as leis sejam viáveis, exequíveis e executáveis, "deve ser lido em todos os artigos onde a Constituição fala em legalidade". ${ }^{47}$

Sobre a positividade dos princípios implícitos vale relembrar a doutrina de SoUTO MAIOR BORGES ${ }^{48}$ :

O princípio implícito não difere senão formalmente do expresso. Têm ambos o mesmo grau de positividade. Não há uma positividade forte (a expressa) e outra fraca (a implícita). Um princípio implícito pode muito bem ter a eficácia (= produzir efeitos) muito mais acentuada do que um princípio expresso.

\footnotetext{
Nenhuma norma tributária há de negar a sua praticabilidade, sob pena de ela se declarar ineficaz”. PONTES, Helenílson Cunha. O princípio da praticidade no Direito Tributário (substituição tributária, plantas de valores, retenções de fontes, presunções e ficções, etc): sua necessidade e seus limites. Revista Internacional de Direito Tributário, v. 2. Minas Gerais: Del Rey, julho/dezembro de 2004, p. 55-56.

42 Ibidem, p. 56.

${ }^{43}$ NABAIS, José Casalta. O Dever Fundamental de Pagar Imposto - Contributo para a compreensão constitucional do estado fiscal contemporâneo. 3. ed. Coimbra: Almedina, 2012. p. 336-337.A outra máxima apontada por A. Smith é o da igualdade (ou justiça) de forma que todos deveriam contribuir o máximo possível em proporção às suas respectivas capacidade. SMITH, Adam. Riqueza das Nações. São Paulo: Folha de São Paulo, 2010, p. 346.

${ }^{44}$ TORRES, Ricardo Lobo. Liberdade, Consentimento e Princípios de Legitimação do Direito Tributário. Revista Internacional de Direito Tributário, v. 5. Minas Gerais: Del Rey, janeiro/julho de 2006, p. 232.

${ }^{45}$ DERZI, Misabel de Abreu Machado. Legalidade material, Modo de Pensar 'Tipificante' e Praticidade no direito tributário. In: I Congresso Internacional de Direito Tributário- IBET. São Paulo: Max Limonad, 1998. p. 639.

${ }^{46}$ DERZI, Misabel de Abreu Machado. Direito tributário, direito penal e tipo, 2. ed. São Paulo: Revista dos Tribunais, 2008, p. 328.

47 DERZI, Misabel de Abreu Machado. Princípio da praticabilidade do direito tributário - segurança jurídica e tributação. Revista de Direito Tributário, São Paulo: Revista dos Tribunais, v. 13, n. 47, p. 175-176, jan.-mar. 1989.

${ }^{48}$ BORGES, Souto Maior. Princípio da Segurança Jurídica na Criação e Aplicação do Tributo. Revista de Direito Tributário, n. 63. São Paulo: Malheiros, 1993, p. 207.
} 
O princípio da praticabilidade não se reduz às atribuições de regulamentar as leis pelo poder executivo. Com uma conotação muito mais ampla, afetando todas as atividades estatais, tem sido compreendida como uma interpretação teleológica devendo-se "colher o sentido da norma que acarrete aplicação mais cômoda, simples, econômica e funcional" ${ }^{49}$

Na concepção de REGINA HelEnA COSTA a praticabilidade também se constitui de autêntico princípio em razão de: “(i) contém elevado grau de generalidade e abstração, irradiando seus efeitos sobre múltiplas normas; (ii) contempla valor considerado fundamental para a sociedade, qual seja, a viabilização da adequada execução do ordenamento jurídico, no campo tributário". ${ }^{50}$

Porém, adverte a autora, "ser inegável a natureza técnica do princípio em foco, o que impede de ser colocado no mesmo patamar dos princípios éticos, como a justiça e a moralidade, posicionados no altiplano do ordenamento jurídico". ${ }^{51}$

FERNANDO AURELIO ZILVETI expõe que "se a lei não puder ser executada por confusa ou por faltar-lhe qualquer requisito que permita objetivamente que seja cumprida, contraria a sua fonte, que é a Constituição" e por essa razão "tal argumento confere à praticabilidade um caráter principiológico". ${ }^{52}$

LUís EDUARDO SCHOUERI ${ }^{53}$ também registra seu entendimento de que a praticabilidade é um princípio ao afirmar que a função simplificadora é "uma função das normas tributárias regida pelo princípio da praticabilidade, autorizando o aplicador da lei a adotar medidas globais, generalizantes, com a finalidade de simplificar o sistema tributário" (grifo nosso).

Com total respeito aos que entendem que a praticabilidade não é um princípio e sim um critério técnico para tornar mais simples e viável a execução das leis, estamos convencidos, com fundamento nas exposições doutrinárias acima transcritas, tratar-se de verdadeira prescrição constitucional com alto grau de abstração que delimitará o âmbito de atuação do legislador infraconstitucional, bem como a interpretação e aplicação das normas tributárias.

Como consequência, os conflitos, que certamente surgirão da praticidade com os outros princípios constitucionais, deverão ser resolvidos pela análise e sopesamento do peso

\footnotetext{
${ }^{49}$ DERZI, Misabel de Abreu Machado. Direito tributário, direito penal e tipo, 2. ed. São Paulo: Revista dos Tribunais, 2008, p. 139.

${ }^{50}$ COSTA, Regina Helena. Praticabilidade e justiça tributária - Exequibilidade de Lei Tributária e Direitos do Contribuinte, São Paulo: Malheiros, 2007. p. 92-93.

${ }^{51}$ Ibidem, p. 93. Dentro de nossas premissas preferimos adotar ao invés de "natureza técnica", princípio que traz valor objetivo, em contraposição aos princípios que encerram valores.

${ }^{52}$ ZILVETTI, Fernando Aurélio. Princípios de Direito Tributário e a Capacidade Contributiva. São Paulo: Quartier Latin, 2004, p. 315.

${ }^{53}$ SCHOUERI, Luís Eduardo. Normas Tributárias Indutoras e Intervenção Econômica. Rio de Janeiro: Forense, 2005. p. 32.
} 
relativo de cada um, em cada caso concreto, juntamente com o cotejo das regras que definem e delimitam de forma mais precisa o mecanismo de realização e escopo de abrangência desses princípios. 


\subsection{Praticabilidade e Eficiência na tributação}

Como é cediço, a tributação não constitui um fim em si mesmo, mas busca atingir determinados propósitos. Os objetivos perquiridos pelo Estado com a tributação modificaramse conforme a evolução da sociedade e de suas necessidades, passando do estigma de servidão nos primórdios, até instrumento de realização de justiça nos dias atuais.

A tributação como instrumento de realização de justiça justificaria a simplificação das normas tributárias?

Desde os primórdios o homem se viu na necessidade de viver em sociedade para garantia de sua subsistência e para o gozo da liberdade.

O Estado, como forma de organização política, requer para sua existência a busca de recursos para sua manutenção pela tributação, que se consubstancia em um poder abstrato de exigir dos indivíduos os meios para realizar os seus próprios fins.

Para Regina Helena Costa a tributação constitui "autêntico poder-dever, cujo exercício traduz-se no emprego de instrumentos que lhe possibilitem a obtenção dos recursos necessários ao desempenho de suas atividades" ${ }_{54}$.

BETINA TREIGER GRUPENMACHER também ressalta que na doutrina contemporânea o direito tributário vincula-se aos direitos fundamentais "a partir da conscientização de que a tributação existe como forma de realização da justiça social, a fim de que se alcance o propósito estabelecido no Texto Constitucional de uma vida digna para todos" ${ }_{55}$.

O tributo trouxe (e ainda traz), por muito tempo e por várias razões, o preconceito da odiosidade por limitar e restringir a liberdade e os direitos dos indivíduos.

EZIO VANONI ${ }^{56}$ demonstra que se admitido o princípio da necessidade da vida em sociedade, não há lógica em enxergar a tributação, como uma limitação qualquer da atividade individual.

Como o direito é norma obrigatória de conduta, não existe direito sem o Estado e sem o direito não existe a personalidade jurídica do indivíduo. Assim a tributação, "longe de ser uma atividade que limite os direitos e a personalidade do indivíduo, é o pressuposto necessário daqueles e desta, porquanto na ausência de tal atividade não haveria Estado, e sem Estado não existiria direito".

\footnotetext{
${ }^{54}$ COSTA, Regina Helena. Curso de Direito Tributário. São Paulo: Saraiva, 2009, p. 3.

${ }^{55}$ GRUPENMACHER, Betina Treiger. Tributação e Direitos Fundamentais. In: FISCHER, Octavio Campos(Coord.). Tributos e Direitos Fundamentais. São Paulo: Dialética, 2004, p. 9.

${ }^{56}$ VANONI, Ezio. Natureza e interpretação das leis tributárias. Rubens Gomes de Souza (trad.). Rio de Janeiro: Financeiras, 1952, p. 140-141.
} 
Embora RICARDO LOBO TORRES ${ }^{57}$ ressalte que historicamente o tributo é figura que surge na época moderna e que seria inútil procurá-lo em períodos anteriores, iremos, de forma sucinta, discorrer sobre a evolução da tributação, que sempre se modificou conforme se alterava a forma de financiamento do Estado, mostrando como passou do estigma de servidão a instrumento de realização de justiça.

$\mathrm{Na}$ antiguidade o tributo teve suas origens pela sujeição política do vencido na guerra, uma vez que pelo direito da época, o vencedor além de o poder de vida e morte sobre o vencido, tornava-se proprietário de suas terras e riquezas. $\mathrm{O}$ tributo surge como uma prestação periodicamente a ser suportada pelo vencido em favor do Estado vencedor, para salvar a sua vida e poder utilizar as terras que não mais lhe pertenciam ${ }^{58}$.

O tributo surgiu, assim, com esse estigma de servidão, pois se sujeitavam à tributação os povos dominados pela guerra e à capitação (tributo cobrado per capita) os estrangeiros, os imigrantes e os forasteiros pelos direitos sobre o uso de portos e mercados e com o produto das minas e salinas ${ }^{59}$.

Em suma, pode-se dizer que o tributo, enquanto sujeição, representava na antiguidade, o preço da falta de liberdade. Somente o cidadão, por ser livre não estava sujeito à tributação.

Essa incompatibilidade da liberdade com a tributação na antiguidade foi se alterando com o feudalismo da Idade Média. Com o cristianismo medieval, a liberdade assume novos contornos, pois se considera que todos têm liberdade de vontade, embora nem todos tenham liberdade de efetivá-la. Passa-se a considerar livre aquele que exerce sua opção conforme sua vontade e contribuir era uma das formas de expressão dessa liberdade.

No exercício desta opção, as pessoas agrupavam-se, colocavam suas famílias e suas terras sob a dependência do senhor, criando os senhorios, e em troca de proteção e do benefício de diversas partes da senhoria, o senhor feudal cobrava os impostos.

Surge, assim, entre os séculos IX e XIII, o Estado Patrimonial, no qual "o fato do Estado, o fato de dever e de pagar o imposto ao Estado, foi substituído pelo fato do senhor e pelo fato de dever e pagar o imposto ao senhor. O rei, a igreja e o senhorio auferiam suas receitas por conta do exercício da propriedade". ${ }^{60}$

\footnotetext{
57 TORRES, Ricardo Lobo. Tratado de Direito Constitucional, Financeiro e Tributário, vol. II, Valores e Princípios Constitucionais Tributários. Rio de Janeiro: Renovar, 2005, p. 125.

${ }^{58}$ VANONI, Ezio. Natureza e interpretação das leis tributárias. Rubens Gomes de Souza (trad.). Rio de Janeiro: Financeiras, 1952, p. 15-16.

${ }^{59}$ Ibidem, p. 16.

${ }^{60}$ SCHOUERI, Luís Eduardo. Direito Tributário. São Paulo: Saraiva, 2011, p. 20.
} 
Este Estado Patrimonial aos poucos foi substituído pelo Estado Policial. Com as ideias de Thomas Hobbes (1588-1679) em sua obra $O$ Leviatã, o homem por meio do pacto social, abriria mão de sua liberdade natural em troca de uma liberdade civil, como forma de garantir sua conservação e uma vida mais confortável.

RICARDO LOBO TORRES, em sua análise da correlação entre os tributos e a liberdade, aponta que na fase do absolutismo, "o tributo é fiador da conquista da riqueza e da felicidade, da liberdade de trabalho e do incentivo ao lucro no comércio e no câmbio"61, concluindo que o imposto passa de forma de opressão da liberdade, a preço da liberdade.

Este Estado Fiscal a quem caberia garantir a liberdade, atuando de forma forte e intervencionista em todos os ramos da sociedade, foi paulatinamente alterado pelo liberalismo, com fundamento na garantia da liberdade da iniciativa econômica.

Adam Smith (1723-1790), um dos grandes pensadores do liberalismo econômico, afirmava que a harmonia e a justiça social só seriam alcançadas com a plena liberdade econômica. ${ }^{62}$

O Estado, sob a crença da "mão invisível” (economia que se autorregulava por leis naturais) do liberalismo, atuando o mínimo possível de forma intervencionista na economia, não tinha mais como gerar sua própria riqueza, cabendo ao particular transferir parte de seu patrimônio, para garantir o financiamento do Estado. Como decorrência, o modelo de Estado de Polícia foi alterado para o Estado Fiscal, cuja principal característica é ser financiado prioritariamente por tributos. ${ }^{63}$

O pagamento de tributos torna-se um dever do cidadão, pois o Estado não gera mais sua riqueza. A fonte de riquezas está no cidadão, que deverá transferir parcela dessa riqueza ao Estado.

Nesta fase, a tributação deixa de ser o preço a ser pago ao Estado para garantir a liberdade dos súditos, para se tornar "o preço a ser pago para que o cidadão ficasse livre das amarras do Estado". ${ }^{64}$

Essa ideia de que o tributo é consequência do exercício de liberdade do indivíduo, começa a ser superada com o surgimento das desigualdades sociais. O conceito de liberdade altera-se da individual para a coletiva, pois a liberdade somente poderá ser gozada se todos tiverem acesso a ela. O centro da liberdade é a sociedade e não o indivíduo. O Estado Fiscal

\footnotetext{
61 TORRES, Ricardo Lobo. Tratado de Direito Constitucional, Financeiro e Tributário, vol. II, Valores e Princípios Constitucionais Tributários. Rio de Janeiro: Renovar, 2005, p. 98.

${ }^{62}$ SCHOUERI, Luís Eduardo. Direito Tributário. São Paulo: Saraiva, 2011, p. 23.

${ }^{63}$ Ibidem, p. 21.

${ }^{64}$ SCHOUERI, Luís Eduardo. Direito Tributário. São Paulo: Saraiva, 2011, p. 24.
} 
mínimo é gradativamente substituído por um Estado Social (ou Estado do Bem-Estar Social), cada vez maior e cada vez mais carente de recursos e no qual a arrecadação legitima-se como "o preço que a sociedade paga para que o Estado reduzindo desigualdades, promova a liberdade das camadas mais desfavorecidas". ${ }^{65}$

No século XX a liberdade individual começa a se confundir com a justiça material, assim como os direitos de liberdade confundem-se com os direitos sociais. RICARDO LOBO TORRES $^{66}$ destaca que neste período prevalece a ideia de liberdade para, "que seria uma liberdade positiva, a garantir direitos, inclusive sociais, para todos" e não mais a liberdade $d e$, aquela de "proteção contra as constrições do Estado".

Esta inflexão da liberdade que se exerce e se concede para atingir um fim caracteriza a evolução do Estado Social Democrático de Direito. Este novo sentido de liberdade é aquele que é reconhecido pelo texto constitucional do Estado Social Democrático de Direito em vista de uma finalidade deste, ou seja, a liberdade é concedida para um determinado fim. ${ }^{67}$

A Constituição Federal de 1988 dispõe em seu art. $1^{\circ}$ que a República Federativa do Brasil se constitui em um Estado Democrático de Direito, tendo como fundamentos a soberania, a cidadania, a dignidade da pessoa humana, os valores sociais do trabalho e da livre iniciativa e o pluralismo político.

No art. $3^{\circ}$ encontram-se os objetivos fundamentais da República: I) construir uma sociedade livre, justa e solidária; II) garantir o desenvolvimento nacional; III) erradicar a pobreza e a marginalização e reduzir as desigualdades sociais e regionais; IV) promover o bem de todos, sem preconceitos de origem, raça, sexo, cor, idade e quaisquer outras formas de discriminação.

Está presente em nossa Constituição a ideia da liberdade para um fim do Estado, qual seja: a dignidade da pessoa humana, conforme os ditames da justiça social, deverá ser atingida a partir da valorização do trabalho humano e da livre iniciativa.

Nosso Estado Social Democrático de Direito, conforme o texto de nossa carta magna, não deve ser neutro, deve valorizar o trabalho humano e a livre iniciativa para que a dignidade da pessoa humana seja plenamente alcançada. ${ }^{68}$

\footnotetext{
${ }^{65}$ SCHOUERI, Luís Eduardo. Direito Tributário. São Paulo: Saraiva, 2011, p. 25.

66 TORRES, Ricardo Lobo. Tratado de Direito Constitucional, Financeiro e Tributário, vol. II, Valores e Princípios Constitucionais Tributários. Rio de Janeiro: Renovar, 2005, p. 80.

${ }^{67}$ SCHOUERI, Luís Eduardo. Tributação e Liberdade. In: PIRES, Adilson Rodrigues; TÔRRES, Heleno Taveira (Coords.). Princípios de Direito Financeiro e Tributário: estudos em homenagem ao Professor Ricardo Lobo Torres. Rio de Janeiro: Renovar, 2006, p. 456.

${ }^{68}$ SCHOUERI, Luís Eduardo. Tributação e Liberdade. In: PIRES, Adilson Rodrigues; TÔRRES, Heleno Taveira (Coords.). Princípios de Direito Financeiro e Tributário: estudos em homenagem ao Professor Ricardo Lobo Torres. Rio de Janeiro: Renovar, 2006, p. 461.
} 
TÉRCIO SAMPAIO FERRAZ JUNIOR também entende que o Estado Social não deve ser neutro ao afirmar que: "Já os objetivos exigidos do Estado Social pressupõem um Estado ativo, que desempenha funções distributivas, que, em última análise, desconhece o dualismo entre Estado e Sociedade". ${ }^{69}$

Luís EduARDo SCHOUERI ${ }^{70}$ sintetiza que no Estado Social Democrático de Direito, constitucionalizado pelo Brasil em 1988, “assegura-se a liberdade dos agentes econômicos (status negativo: liberdade de agir), mas busca-se a liberdade das camadas sociais mais desfavorecidas, reduzindo-se as desigualdades (status positivo)”, ou seja, “O Estado de Direito quer a liberdade de todos".

Nesta concepção o tributo não representa mais um ônus para o exercício da liberdade, mas sim instrumento para a concretização. Nas palavras de RICARDO LOBO TORRES ${ }^{71}$ ao fazer referência à tributação: "a lei financeira serve de instrumento para a afirmação da liberdade, para consecução da justiça e para a garantia e segurança dos direitos fundamentais".

O professor carioca sintetiza bem a relação entre tributo e liberdade ao afirmar que: “As relações entre liberdade e tributo no Estado de Direito são de absoluta essencialidade. Não existe tributo sem liberdade, e a liberdade desaparece quando a garante no tributo. A própria definição de tributo se inicia pela noção de liberdade". ${ }^{72}$

REGINA HELENA COSTA $^{73}$ traz à tona a associação entre tributação e cidadania. Como contribuir para as despesas do Estado representa um aspecto do exercício de cidadania, conclui-se que "ser cidadão também é ser contribuinte". Somente poderá ser considerado cidadão aquele que manifestar capacidade contributiva: auferir renda, deter patrimônio e realizar consumo.

O tributo como instrumento a serviço da política social e econômica do Estado Social Democrático de Direito traz como consequência a importância do aspecto arrecadatório, além de consignar a solidariedade como nova fundamentação ao dever de recolher tributos.

Fica superada a concepção liberal de que a tributação tenha a única e exclusiva função de arrecadar recursos para a manutenção do Estado. A tributação não se constitui em um fim em si mesmo, mas como instrumento para que o Estado possa cumprir sua função social.

\footnotetext{
${ }^{69}$ FERRAZ JR, Tércio Sampaio. Estudos de Filosofia do Direito. Reflexões sobre o Poder, a Liberdade, a Justiça e o Direito. $2^{\text {a }}$. edição. São Paulo: Atlas, 2003, p. 80.

${ }^{70}$ SCHOUERI, Luís Eduardo. Tributação e Liberdade. In: PIRES, Adilson Rodrigues; TÔRRES, Heleno Taveira (Coords.). Princípios de Direito Financeiro e Tributário: estudos em homenagem ao Professor Ricardo Lobo Torres. Rio de Janeiro: Renovar, 2006, p. 462.

71 TORRES, Ricardo Lobo. Tratado de Direito Constitucional, Financeiro e Tributário, vol. II, Valores e Princípios Constitucionais Tributários. Rio de Janeiro: Renovar, 2005, p. 42.

72 TORRES, Ricardo Lobo. Sistemas Constitucionais Tributários. Rio de Janeiro: Forense, 1986, p. 186.

${ }^{73}$ COSTA, Regina Helena. Curso de Direito Tributário. São Paulo: Saraiva, 2009, p. 5.
} 
Em razão dos impostos, no Estado Social, não perquirirem apenas uma finalidade reditícia, mas sim diversos objetivos extrafiscais tais como os de natureza social, JOSÉ CASALTA NABAIS $^{74}$ entende que deva ser dada à administração flexibilidade na aplicação da lei do imposto, em razão de sua impotência prática para dominar a realidade.

Essa flexibilidade ou margem de livre decisão atribuída à administração fiscal, em razão dos limites do legislador para dominar totalmente a realidade social, permite-lhe "actuar eficazmente contra a fraude e a evasão fiscais, permitidas por um sistema que arvore a reserva de lei em valor absoluto, e deixe, por impossibilidade prática, de prever ou de prever adequadamente a tributação de factos que eminentes razões de justiça exigem". ${ }^{75}$

Estabelecida a dependência entre a tributação e a efetividade das funções estatais impostas pela Constituição, resta clara a necessidade do Estado de um sistema fiscal eficiente e ágil para arrecadar, com o menor dispêndio possível, os recursos necessários para o cumprimento de suas funções sociais.

O problema da eficiência na tributação já era estudado pelos economistas desde o liberalismo, constituindo-se em duas das quatro máximas de ADAM SMITH ${ }^{76}$ sobre os impostos: comodidade e economia na cobrança (eficiência). Para se ter uma tributação eficiente, "todo o imposto deve ser arquitetado tão bem que tire o mínimo possível do bolso das pessoas para além do que traz para o erário público".

A eficiência foi inserida ${ }^{77}$ no art. 37, caput, como um dos princípios constitucionais da administração pública, pela emenda constitucional nº 19 de 1998.

Para Hely LOPES MeIRELleS ${ }^{78}$ trata-se do mais moderno princípio da função administrativa, "que já não se contenta em ser desempenhada apenas com legalidade, exigindo resultados positivos para o serviço público e satisfatório atendimento das necessidades da comunidade e de seus membros".

Para MARIA SYlvia ZANElla Di PIETRO ${ }^{79}$ o princípio constitucional da eficiência traz como objetivo alcançar os melhores resultados na prestação do serviço público, podendo ser analisado por dois aspectos: (i) em relação ao modo de atuação do agente público; e (ii) em relação ao modo de organizar, estruturar, disciplinar a Administração Pública.

\footnotetext{
${ }^{74}$ NABAIS, José Casalta. O Dever Fundamental de Pagar Imposto - Contributo para a compreensão constitucional do estado fiscal contemporâneo. 3. ed. Coimbra: Almedina, 2012. p. 337.

${ }^{75}$ Ibidem, p. 335.

${ }^{76}$ As outras duas máximas são: igualdade (capacidade contributiva) e certeza (segurança jurídica). SMITH, Adam. Riqueza das Nações. São Paulo: Folha de São Paulo, 2010, p. 346.

${ }^{77}$ A administração pública direta e indireta de qualquer dos Poderes da União, dos Estados, do Distrito Federal e dos Municípios obedecerá aos princípios de legalidade, impessoalidade, moralidade e eficiência e, também ao seguinte: [...]

${ }^{78}$ MEIRELLES, Hely Lopes. Direito administrativo brasileiro. São Paulo: Malheiros, 1996, p. 90-91.

${ }^{79}$ DI PIETRO, Maria Sylvia Zanella. Direito Administrativo. 15a. ed. São Paulo: Atlas, 2003, p.83.
} 
ALEXANDRE DE MORAES ${ }^{80}$ também entende que o princípio da eficiência "impõe à administração pública direta e indireta e a seus agentes a persecução do bem comum”, adotando-se "critérios legais e morais necessários para melhor utilização possível dos recursos públicos, de maneira a evitarem-se desperdícios e garantir-se maior rentabilidade social”.

Essa persecução do bem comum, impondo a atuação eficiente da administração pública, decorre da própria razão da existência do Estado, o que no âmbito das relações tributárias pode ser traduzido no poder-dever da administração pública criar meios para que a legislação possa ser aplicável aos milhões de contribuintes, de forma a satisfazer suas pretensões arrecadatórias e distributivas, alcançando assim o ideal de justiça na tributação.

\subsubsection{Limites para a Eficiência Administrativa}

Poderia então a administração, em nome desse poder-dever ditado pela eficiência ignorar totalmente os princípios da segurança jurídica, legalidade, igualdade e capacidade contributiva?

Pensamos que não. Ainda que exista desproporção entre a incumbência legalmente imposta à administração fazendária na aplicação e fiscalização dos tributos e a sua capacidade e os meios disponíveis para executá-las de forma eficiente, isto não justifica uma discricionariedade tal que conduza ao arbítrio.

Como bem salientou PAUlo de BARRos CARVALHO ${ }^{81}$ :

A atividade jurídico tributária, no Brasil, há de ser desenvolvida em clima de total aderência aos textos legais, além de observância rigorosa dos grandes primados que a Lei Fundamental proclama. Tal concepção, que penetra hoje os sistemas positivos de todos os países civilizados, dista de permitir qualquer traço de arbitrariedade, afastando também, quase sempre, os atos de competência discricionária que poderiam vir a ser praticados pelos funcionários do Estado-Administração nesse campo de atividade administrativa.

A eficiência caracteriza-se por ser uma metanorma que não tem um fim em si mesma, mas antes atua como critério para aplicação de outras normas, estabelecendo um determinado nível (máximo ou minimamente satisfatório) de realização de outras normas. ${ }^{82}$

\footnotetext{
${ }^{80}$ MORAES, Alexandre de. Direito Constitucional. 17a. edição. São Paulo: Atlas, 2005, p. 300.

${ }^{81}$ CARVALHO, Paulo de Barros. A prova no procedimento administrativo tributário. Revista de Direito Tributário, n. 34 . São Paulo: Revista dos Tribunais, 1998, p. 112.

82 ÁVILA, Humberto. Substituição tributária e base de cálculo: os limites da padronização fiscal. Revista da Ajuris, v.32, n.100. Porto Alegre: Livraria do Advogado, 2005, p. 175.
} 
A partir desta consideração, pode-se afirmar que a "eficiência não cria poder, mas calibra o exercício de um poder já previamente concedido", isto é, a eficiência não cria competência tributária e nem alarga a competência previamente estabelecida pela Constituição, apenas estabelece um determinado grau de realização dos princípios constitucionais dentro do poder atribuído pela competência.

A eficiência não justifica desta forma, que em nome da praticabilidade, as pessoas jurídicas de direito público ao criarem mecanismos de simplificação, ultrapassem os limites de sua competência, tributando fatos signos de riqueza não previstos nos arquétipos constitucionais, ou que já se encontrem nas hipóteses de incidência de tributos, de competência de outros entes federativos.

Como sintetizou HumBERTo Ávila:

Essas conclusões inviabilizam a tese segundo a qual o denominado princípio da eficiência administrativa justificaria a criação de ficções ou presunções fora do poder atribuído pelas regras de competência. O dever de eficiência não cria poder inexistente nem amplia poder existente; ele apenas estrutura a aplicação dos princípios tributários dentro do âmbito de poder atribuído pelas regras. Sendo assim, os entes federados não podem, em nome da eficiência, supor a existência de renda onde ela não estiver comprovada; conjeturar a existência de venda de mercadoria nos casos em que ela não for verificada, e assim sucessivamente. ${ }^{83}$

Além do mais, a eficiência encontra limites nos princípios da segurança jurídica, isonomia e da capacidade contributiva que "não podem ser desvirtuados de suas funções e manipulados para servir como critérios finalísticos destinados a garantir não uma proteção dos cidadãos contra o Estado, mas, ao revés, um direito à cobrança de tributos, criando regimes de exceção, sem autorização constitucional". ${ }^{84}$

Dentro dos limites estabelecidos pelo próprio ordenamento, o mandamento constitucional da eficiência administrativa deve sempre ser perquirido. Isto se traduz na tributação como a realização eficiente da igualdade, isto é, a administração deve garantir a participação de todos na obtenção da receita necessária para persecução do bem comum e, para isso, a praticabilidade, possibilitando a aplicação do tributo em massa, torna-se indispensável para a realização de tal desiderato constitucional.

\footnotetext{
${ }^{83}$ ÁVILA, Humberto. Substituição tributária e base de cálculo: os limites da padronização fiscal. Revista da Ajuris, v.32, n.100. Porto Alegre: Livraria do Advogado, 2005, p. 176.

${ }^{84}$ TORRES, Heleno Taveira. Garantias Constitucionais ao Controle sobre Preços de Transferência (Legalidade e Uso de Presunções no Arbitramento da Base de Cálculo dos Tributos, a partir do Controle de Preços de Transferência. O Direito ao Emprego do Melhor Método. Um Caso: Limites ao Uso do PRL-60 na Importação). In: FISCHER, Octavio Campos(Coord.). Tributos e Direitos Fundamentais. São Paulo: Dialética, 2004, p. 122.
} 


\section{Técnicas Simplificadoras}

O princípio da praticabilidade irá exigir do legislador tributário a elaboração de leis de aplicação e execução seja eficazes e eficientes, ou seja, as normas tributárias deverão permitir: a arrecadação, fiscalização e controle dos tributos, de maneira a evitar tanto a investigação exaustiva de casos isolados, com fulcro na redução de custos, como a dispensa de se obter provas difíceis ou mesmo impossíveis da ocorrência do fato gerador em cada caso individualmente considerado.

Tal empresa pode ser obtida de duas formas: (i) utilizar instrumentos de simplificação das normas tributárias, objetivando atenuar a complexidade e possibilitar sua aplicação em massa; ou (ii) investir fortemente em recursos materiais e humanos da administração tributária para adequá-la às reais necessidades que a execução e aplicação das leis demandam.

Por óbvio que nosso estudo concentrar-se-á na primeira opção, face às deficiências crônicas orçamentárias da administração, seja em razão da lei de responsabilidade fiscal que limita os investimentos e modernização do serviço público, seja pela supercomplexidade do nosso manicômio jurídico-tributário ${ }^{l}$, ou pela explosão demográfica e globalização das relações econômicas, estamos convencidos de que dificilmente essa solução seria viável para garantir a coerência e eficiência do sistema tributário. ${ }^{2}$

JosÉ CASALTA NABAIS ${ }^{3}$ ao ponderar sobre os sistemas fiscais dos países desenvolvidos traz a conclusão que julgamos perfeitamente aplicável em nosso país. Partindo também da constatação de que naqueles países há uma supercomplexidade do sistema tributário pela avalanche de normas, "raramente a praticabilidade se conseguirá apenas pela via do reforço da capacidade da administração".

\footnotetext{
${ }^{1}$ BECKER, Alfredo Augusto. Teoria Geral do Direito Tributário. 5.ed.São Paulo: Noeses, 2010, p. 3.

${ }^{2}$ Neste sentido: “[...] não há aplicadores em número suficiente. O problema não pode ser resolvido, pura e simplesmente, pelo aumento, ao infinito da máquina fiscal”. PAOLA, Leonardo Sperb de. Presunções e ficções no direito tributário. Belo Horizonte: Del Rey, 1997, p. 101. De opinião contrária: "Realmente o Fisco, de uma maneira geral, está despreparado para lidar com o ritmo atual da economia, que exige capacidade de adaptações rápidas às mudanças, aparato tecnológico avançado e treinamento constante de pessoal especializado, porém, no mais das vezes esse despreparo é fruto de sua própria incompetência e da pouca visão dos governantes, não sendo inevitável e, portanto, que deveria ser corrigido pelo direito. Ao contrário, se houvesse o devido treinamento e valorização do pessoal, uma política tributária séria, uma fiscalização severa da própria atividade fiscalizadora e um aparelhamento adequado, com certeza a arrecadação iria aumentar, diminuir-se-ia a sonegação e a fraude tributária. E, com cristalina certeza, não seria necessário fazer olhos de mercador para o princípio da segurança jurídica e da tipicidade estrita". SCHERKERKEWITZ, Iso Chaitz. Presunções e Ficções no Direito Tributário e no Direito Penal Tributário. Rio de Janeiro: Renovar, 2002, p.23-24.

${ }^{3}$ NABAIS, José Casalta. O Dever Fundamental de Pagar Imposto - Contributo para a compreensão constitucional do estado fiscal contemporâneo. 3. ed. Coimbra: Almedina, 2012. p. 621-622.
} 
A solução, conclui o autor, deve ser o enfretamento com coragem e determinação do problema da efetiva simplificação das leis tributárias, "tanto no seu sentido material relativo ao sistema fiscal no seu conjunto e aos impostos que harmonicamente o devem integrar, como no seu sentido formal concernente às regras de aplicação dos impostos, mormente as relativas ao conjunto de obrigações e competências tributárias em sede de liquidação e cobrança dos mesmos e à organização da administração fiscal".

Conforme salientamos anteriormente, existe um intervalo inevitável entre a realidade social e a realidade jurídica constituída pela linguagem do direito, que seleciona na elaboração dos enunciados normativos, quais aspectos do suporte físico ingressam e quais não ingressam nos domínios do direito ${ }^{4}$, isto é, quais fatos sociais poderiam alcançar o status de fatos jurídicos.

A realidade social, em face de sua complexidade, um continum ${ }^{5}$ heterogêneo sem limites, não pode ser recepcionada em sua inteireza de detalhes pelo ordenamento jurídico, sob pena de ao fazê-lo, obstaculizar sua aplicação.

A técnica legislativa deve, portanto, para garantir a elaboração de normas eficazes, ter como missão: "a redução simplificadora dos elementos substanciais do Direito". ${ }^{6}$ A função precípua da técnica legislativa "é garantir a praticabilidade do Direito, tornar as normas jurídicas mais eficazes, trabalhar ideais jurídicos que, em sua formulação inicial, dificilmente seriam aplicáveis aos fatos concretos". ${ }^{7}$

O legislador por essa razão se vê obrigado a utilizar abstrações generalizantes como forma de garantir que o direito possa acompanhar a dinâmica da realidade social, ainda que, as normas gerais e abstratas permaneçam imutáveis, o que implica em dizer que "o ordenamento é fechado em termos sintáticos, mas aberto nos níveis semântico e pragmático". ${ }^{8}$

Neste mesmo sentido, PAUlo Ayres BARRETO ${ }^{9}$ entende que em face da multiplicidade de aspectos da realidade social, a linguagem jurídica nem sempre é capaz de captar toda a facticidade a ser normada e, portanto, prescinde-se "de atingir a realidade social em sua inteireza e com o uso de padronizações, presunções e ficções, busca-se a configuração

\footnotetext{
${ }^{4}$ CARVALHO, Paulo de Barros. Fundamentos Jurídicos da Incidência Tributária. 8. ed.. São Paulo: Saraiva, 2010, p. 156.

${ }^{5}$ CARVALHO, Paulo de Barros. Fundamentos Jurídicos da Incidência Tributária. 8. ed.. São Paulo: Saraiva, 2010, p. 24.

${ }^{6}$ PAOLA, Leonardo Sperb de. Presunções e ficções no direito tributário. Belo Horizonte: Del Rey, 1997, p. 53.

${ }^{7}$ Ibidem, p. 52.

${ }^{8}$ Ibidem, p. 156-157. Segundo o autor: "É curioso notar que o direito positivo, sendo, como é, um subsistema do sistema social total, mesmo que paralisado no campo da produção legislativa, equivale a dizer, ainda que suas normas gerais e abstratas permaneçam imutáveis, sem qualquer atualização de forma, continua em movimentação, alterando-se, no tempo, o quadro de suas significações. O fenômeno se explica por força, principalmente, da maleabilidade dos planos semânticos e pragmático de sua linguagem. A dimensão sintática, mais rígida e, portanto, resistente a mutações, mostra-se morosa e tardia. Modifica-se, mas somente pela dinâmica incessante dos outros dois ângulos da concepção semiótica.

${ }^{9}$ BARRETO, Paulo Ayres. Imposto Sobre a Renda e Preços de Transferência. São Paulo: Dialética, 2001, p. 139.
} 
de um tipo legal mais simples, médio, padrão, que facilite o reconhecimento da ocorrência do fato jurídico tributário e, consequentemente, a cobrança do tributo devido".

As técnicas simplificadoras podem ser utilizadas pelo legislador sem qualquer compromisso com o combate à fraude ou em simplificar a atividade administrativa, isto é, no sentido horizontal, com fulcro em tornar possível o manejo da realidade social na sua inerente complexidade.

Essas técnicas buscam "transformar qualidade de difícil mensuração em quantidade" 10 , reduzindo a complexidade dos elementos substanciais do direito, o que, embora de extrema importância e imprescindibilidade para a operacionalidade do direito, não conflitam, na maioria das vezes com os princípios constitucionais, razão pela qual não lhes dedicaremos maior atenção. ${ }^{11}$

Nosso foco estará centrado nas técnicas simplificadoras que buscam potencializar a eficiência arrecadatória, isto é no sentido vertical, para solucionar ou buscar solucionar o problema de quantidade cada vez maior de contribuintes e de relações materiais tributáveis, contrapondo-se a uma estrutura administrativa que não cresce na mesma proporção.

Neste caso não há dificuldade em se apreender o fato econômico da realidade social pelo aplicador da norma; a impossibilidade surge em razão de não haver (e talvez nunca haja) agentes administrativos suficientes para o elevado número de contribuintes e das relações sociais.

As técnicas simplificadoras tendem, neste caso, ao abandono da investigação exaustiva de provas de cada caso concreto, substituindo-se por médias, padrões ou generalizações, com intuito de assegurar a satisfação do mandamento normativo.

As críticas da doutrina situam-se nestas técnicas, por entenderem que o abandono do individual pela generalidade conflita, entre outros, com vários princípios constitucionais, como da capacidade contributiva, segurança e legalidade.

Nossos esforços serão no intuito de perquirir os limites impostos a estas normas simplificadoras, ponderando o princípio da praticabilidade ao qual estão a serviço, com os demais princípios de nossa ordem constitucional.

\footnotetext{
${ }^{10}$ PAOLA, Leonardo Sperb de. Presunções e ficções no direito tributário. Belo Horizonte: Del Rey, 1997, p. 101.

${ }^{11}$ Leonardo Sperb de Paola ilustra como exemplo de simplificação neste sentido a utilização da ficção quando da definição do período impositivo nos tributos com aspecto material da hipótese de incidência continuado, como no caso do imposto de renda e do IPTU, os quais "sem o estabelecimento do período impositivo, sem a fixação arbitrária de um corte temporal, seria de difícil constatação". PAOLA, Leonardo Sperb de. Presunções e ficções no direito tributário. Belo Horizonte: Del Rey, 1997, p. 100.
} 
Assentadas essas conclusões iniciais, necessário se faz discorrer sobre as principais técnicas que o legislador e o aplicador do direito utilizam com mais frequência, na execução simplificadora das leis, para então identificarmos os limites constitucionais à sua utilização.

\subsection{Indeterminabilidade como técnica legislativa}

Em razão da inevitável distância entre o direito e a realidade social, muitas vezes o legislador propositadamente utiliza-se da indeterminabilidade como forma de simplificação e praticabilidade, vez que, ao tentar exaurir detalhadamente todas as materialidades a serem juridicizadas, quase sempre, ensejará numa legislação extremamente complexa, cuja aplicação torna-se inviável.

Como bem observa CANOTILHO $^{12}$, a determinabilidade ou indeterminabilidade das leis tem muito a ver com a distribuição de tarefas entre o legislador e o aplicador ou executor. A indeterminabilidade justiça-se normalmente pelo fato de o legislador limitar-se a leis de direção, deixando à administração "amplos poderes de decisão adaptativa".

KARL ENGISCH ${ }^{13}$ também doutrina que já houve um tempo em que se acreditou na ideia de que seria possível "estabelecer uma clareza e segurança jurídica absolutas através de normas rigorosamente elaboradas, e especialmente garantir uma absoluta univocidade a todas as decisões judiciais e a todos os atos administrativos”.

Todavia, nos dias de hoje, as leis são elaboradas de tal forma que a administração não mais fundamente suas decisões somente com a subsunção a conceitos jurídicos fixos, "mas antes são chamados a valorar autonomamente e, por vezes, a decidir e a agir de modo semelhante ao do legislador. E assim continuará no futuro. Será sempre questão duma maior ou menor vinculação à lei”.

\footnotetext{
12 Embora reconheça que: "O controle destas normas abertas deve ser reforçado. Elas podem, por um lado, dar cobertura a uma inversão das competências constitucionais e legais; por outro lado, poder tornar claudicante a previsibilidade normativa em relação ao cidadão e ao juiz. De facto, as cláusulas gerais podem encobrir uma menor valia democrática, cabendo, pelo menos, ao legislador, uma reserva legal dos aspectos essenciais da matéria a regular. A exigência da determinabilidade das leis ganha particular acuidade no domínio das leis restritivas ou de leis autorizadoras de restrição". CANOTILHO, J.J. GOMES. Direito Constitucional e Teoria da Constituição. 5a . edição. Coimbra: Livraria Almedina, 1991.

${ }^{13}$ ENGISH, Karl. Introdução ao Pensamento Jurídico. trad. de João Baptista Machado. $7^{\text {a }}$. ed. Lisboa: Calouste Gulbenkian, 1996, p.206-208.
} 
Dentre os modos de expressão legislativa que permitem ao aplicador da lei adquirir maior autonomia em face da lei, destacam-se os conceitos indeterminados e as cláusulas gerais. $^{14}$

Os conceitos indeterminados surgem em razão da impossibilidade do legislador empregar termos tão precisos, que definiriam com exatidão as inúmeras situações da vida. $\mathrm{Na}$ definição de ENGISCH são conceitos "cujo conteúdo e extensão são em larga medida incertos", afirmando que "os conceitos absolutamente determinados são muito raros no Direito". ${ }^{15}$

As cláusulas gerais, que não se confundem com os conceitos indeterminados, são na definição de ENGISCH${ }^{16}$ : "uma formulação da hipótese legal que, em termos de grande generalidade, abrange e submete a tratamento jurídico todo um domínio de casos”.

Ao contrapor o conceito de cláusulas gerais à uma elaboração casuística $^{17}$ das hipóteses legais, o jurista nos ensina que: “O verdadeiro significado das cláusulas gerais reside no domínio da técnica legislativa. Graças à sua generalidade, elas tornam possível sujeitar um mais vasto grupo de situações, de modo ilacunar e com possibilidade de ajustamento, a uma consequência jurídica". ${ }^{18}$

EROS GRAU ${ }^{19}$ sustenta a tese de que não existem conceitos indeterminados, partindo do pressuposto que "todo conceito é uma suma de ideias, que, para ser conceito, tem de ser, no mínimo, determinada" e "se o conceito não for, em si, uma suma determinada de ideias, não chega a ser conceito".

A indeterminação ocorre nas suas expressões (termos) e não nos conceitos jurídicos (ideias universais), razão pela qual seria falarmos em "termos indeterminados de conceitos e não a conceitos (jurídicos ou não) indeterminados". ${ }^{20}$

Em que pese a respeitável consideração do jurista, não nos subscrevemos integral à ela por entender que a indeterminabilidade não se refere simplesmente aos termos utilizados, mas engloba uma ideia maior de elasticidade, flexibilidade, enfim, de algo propositadamente mais aberto para comportar várias situações distintas..$^{21}$

\footnotetext{
${ }^{14}$ Karl Engisch destaca distingue como modos de expressão legislativa que afrouxam o vínculo que prende à lei os tribunais e as autoridades administrativas: os conceitos jurídicos indeterminados, os conceitos normativos, os conceitos discricionários e as cláusulas gerais. Ibidem, p. 208.

15 Ibidem, p. 208.

${ }^{16}$ ENGISH, Karl. Introdução ao Pensamento Jurídico. trad. de João Baptista Machado. 7a. ed. Lisboa: Calouste Gulbenkian, 1996, p.229.

17 "O casuísmo está sempre exposto ao risco de apenas fragmentária e provisoriamente dominar a matéria jurídica. Este risco é evitado pela utilização das cláusulas gerais". Ibidem, p. 233-234.

${ }^{18}$ Ibidem, p.233.

${ }^{19}$ GRAU, Eros Roberto. Direito, Conceitos e Normas Jurídicas. São Paulo: RT, 1988, p. 76.

${ }^{20}$ Ibidem, p. 76.

${ }^{21}$ Neste sentido: "Nem sempre se deve considerar a indeterminação dos conceitos como uma imperfeição ou vício de linguagem cotidiana, senão com uma de suas propriedades que permite cumprir a função de expressar e valorar condutas, relações e objetos
} 
O conceito, ainda que represente as propriedades do objeto, "não é necessariamente unívoco, eis que se determina no contexto da proposição". ${ }^{22}$

A indeterminação é uma das características das linguagens não formalizadas, pois como bem lembra PAUlO DE BARros CARVALHO 23: "A plurissignificação é algo que está constantemente presente no discurso jurídico, como, de resto, em todas as linguagens materiais, saturadas com significações concretas. Livram-se desse problema semântico apenas as linguagens formais[...]"

Segundo LUís EDUARDO SCHOUERI ${ }^{24}$, não se pode esperar que o legislador defina com precisão a hipótese tributária, uma vez que ele vale-se de palavras e com palavras não é possível afastar "certo grau de vagueza".

O mestre ora citado, assevera que "é por isso que boa parte dos doutrinadores vem reconhecendo que, em matéria tributária, surge o emprego, pelo legislador, de cláusulas gerais e conceitos indeterminados, sem que por isso se fira o Princípio da Legalidade".

No seu entender a segurança jurídica não ficaria mitigada pelo emprego de cláusulas gerais e conceitos indeterminados em matéria tributária, "desde que se tenha em mente que, conceitos indeterminados, na lei, podem ser determinados no momento de sua aplicação". ${ }^{25}$

Assim, podemos ficar com a definição de que conceitos indeterminados são conceitos que, mediante uma única hipótese, comportam múltiplas situações e a resposta válida, ou a resposta justa, somente poderá ser alcançada a partir das considerações de fato. ${ }^{26}$

Embora reconheça que o direito tributário esteja subordinado ao princípio da determinação, segundo o qual os conceitos devem, sempre que possível, ser determinados, RICARDO LOBO TORRES admite que os conceitos indeterminados e as cláusulas gerais são inevitáveis ${ }^{27}$, devendo o direito tributário aprender a conviver com a tensão entre ambos.

Como exemplo de conceitos jurídicos indeterminados ${ }^{28}$, presentes do direito tributário, podemos citar: "valor venal do imóvel", "habitualidade", "disponibilidade jurídica"

materiais, bem como de ensejar a mutação evolutiva do Direito". COSTA, Regina Helena. Praticabilidade e justiça tributária - Exequibilidade de Lei Tributária e Direitos do Contribuinte, São Paulo: Malheiros, 2007, p.176.

${ }^{22}$ TORRES, Ricardo Lobo. O princípio da Tipicidade no Direito Tributário. Revista Eletrônica de Direito Administrativo Econômico, Salvador, Instituto de Direito Público da Bahia, nº. 5, fev/ar/abr de 2006. Disponível na Internet: < http://www.direitodoestado.com.br>. Acesso em: 15 de fevereiro de 2013, p. 14.

${ }^{23}$ CARVALHO, Paulo de Barros. Fundamentos Jurídicos da Incidência Tributária. 8. ed.. São Paulo: Saraiva, 2010, p. 234.

${ }^{24}$ SCHOUERI, Luís Eduardo. Direito Tributário. São Paulo: Saraiva, 2011, p. 286.

${ }^{25}$ Ibidem, p. 289.

${ }^{26}$ PONTES, Helenílson Cunha. O princípio da praticidade no Direito Tributário (substituição tributária, plantas de valores, retenções de fontes, presunções e ficções, etc): sua necessidade e seus limites. Revista Internacional de Direito Tributário, v. 2. Minas Gerais: Del Rey, julho/dezembro de 2004, p. 58.

27 TORRES, Ricardo Lobo. O princípio da Tipicidade no Direito Tributário. Revista Eletrônica de Direito Administrativo Econômico, Salvador, Instituto de Direito Público da Bahia, no. 5, fev/ar/abr de 2006. Disponível na Internet: < http://www.direitodoestado.com.br>. Acesso em: 15 de fevereiro de 2013, p. 14-15.

${ }^{28}$ COSTA, Regina Helena. Praticabilidade e justiça tributária - Exequibilidade de Lei Tributária e Direitos do Contribuinte, São Paulo: Malheiros, 2007, p. 248. 
etc. Não é possível definir esses conceitos a priori, senão somente diante de fatos concretos da realidade que poderão assumir significações.

Um exemplo de cláusula geral presente em nosso ordenamento ${ }^{29}$ é a expressão "proventos de qualquer natureza, assim entendidos os acréscimos patrimoniais não compreendidos no inciso anterior" citada no art. 43, inciso II do CTN, bem como a equidade que fundamenta a remissão do crédito tributário, prevista no art. 172, inciso IV do CTN. ${ }^{30}$

Nas considerações de Regina HelenA CostA ${ }^{31}$, “a indeterminação é qualidade inerente aos conceitos empregados na linguagem jurídica - e, portanto, ineliminável”, o que implicaria em que "a utilização de conceitos jurídicos indeterminados pode traduzir a praticabilidade no âmbito tributário, na medida em que tais conceitos, por sua elasticidade, habilitam a lei, mediante uma única hipótese, a comportar múltiplas situações, bem como, por vezes, ensejam o exercício da discricionariedade administrativa". ${ }^{32}$

Os conceitos indeterminados, como afirmado, ensejam o exercício da discricionariedade administrativa, mas com ela não se confunde. ${ }^{33}$

De acordo com MARIA SYLVIA ZANELLA DI PIETRO ${ }^{34}$, a discricionariedade ocorre quando "a lei deixa certa margem de decisão diante do caso concreto, de tal modo que a autoridade poderá optar por uma dentre várias soluções possíveis, todas válidas perante o direito". (grifo nosso)

A diferença básica reside no número de possibilidades de decisões: quando tivermos várias possibilidades, todas elas juridicamente admissíveis, que a autoridade administrativa poderá escolher, estaremos diante da discricionariedade; mas, quando, somente uma decisão é juridicamente admissível, estaremos falando de um conceito indeterminado.

\footnotetext{
${ }^{29}$ COSTA, Regina Helena. Praticabilidade e justiça tributária - Exequibilidade de Lei Tributária e Direitos do Contribuinte, São Paulo: Malheiros, 2007, p. 249.

${ }^{30}$ TORRES, Ricardo Lobo. O princípio da Tipicidade no Direito Tributário. Revista Eletrônica de Direito Administrativo Econômico, Salvador, Instituto de Direito Público da Bahia, $\mathrm{n}^{\circ}$. 5, fev/ar/abr de 2006. Disponível na Internet: < http://www.direitodoestado.com.br>. Acesso em: 15 de fevereiro de 2013, p. 16.

${ }^{31}$ COSTA, Regina Helena. Praticabilidade e justiça tributária - Exequibilidade de Lei Tributária e Direitos do Contribuinte, São Paulo: Malheiros, 2007, p. 183.

32. Quanto ao fato dos conceitos indeterminados conferirem a discricionariedade à administração, a polêmica doutrinária dividese em duas grandes correntes: (i) os que entendem não ser possível, pois diante deles, cabe à administração um trabalho de interpretação que levará à única solução válida possível; e (ii) os que entendem ser possível, desde que se trate de conceitos de valor (moralidade, interesse público, utilidade pública etc.), os quais implicam na possibilidade de apreciação do interesse público em cada caso concreto, e, não de conceitos de experiência ou técnicos (dependem de manifestação de órgão técnico), que não admitem mais de uma solução juridicamente válida. DI PIETRO, Maria Sylvia Zanella. Direito Administrativo. $15^{a}$. ed. São Paulo: Atlas, 2003, p.208

33 "Os conceitos indeterminados não se confundem com o fenômeno da discricionariedade. Tomando-se a distinção entre os dois elementos da norma, isto é, o fato gerador e o efeito jurídico, ter-se-á que os conceitos indeterminados se aplicam para a descrição do fato, enquanto a discricionariedade se situa no campo dos efeitos". SCHOUERI, Luís Eduardo. Distribuição Disfarçada de Lucros. São Paulo: Dialética, 1996, p. 111.

${ }^{34}$ DI PIETRO, Maria Sylvia Zanella. Direito Administrativo. 15a . ed. São Paulo: Atlas, 2003, p.205. Segundo a autora: "Nestes casos, o poder da Administração é discricionário, porque a adoção de uma ou outra solução é feita segundo critérios de oportunidade, conveniência, justiça, equidade, próprios da autoridade, porque não definidos pelo legislador".
} 
A discricionariedade surge, assim, como elemento que integra a competência do agente administrativo, quando nos deparamos com os indiferentes jurídicos, que são opções irrelevantes para o direito. ${ }^{35}$

Embora reste claro que não se pode imaginar a discricionariedade, em respeito aos princípios da segurança jurídica, legalidade, entre outros, na definição da hipótese de incidência, o mesmo não se pode afirmar dos conceitos indeterminados e das cláusulas gerais. ${ }^{36}$

Em razão de sua flexibilidade, quando mediante uma única hipótese, comporta múltiplas situações, torna sua utilização um corolário da praticabilidade que visa, em razão da aplicação em massa das normas tributárias, contemplar um número cada vez maior de possibilidades, sob pena de perder a efetividade.

O mesmo se pode afirmar sobre a utilização de cláusulas gerais, uma vez que "não, há, efetivamente, fundamento jurídico que imponha ao legislador a indicação pormenorizada e exauriente de todas as situações a serem enquadradas nos conceitos legais, com a criação de uma legislação demasiadamente extensa e complexa, que, certamente padecerá do defeito de excesso de casuísmo". ${ }^{37}$

Não queremos afirmar que em razão da dificuldade da atividade legislativa de prever todas as circunstâncias de todos os casos concretos, as abstrações como os conceitos indeterminados e cláusulas gerais têm sua utilização liberada e sem quaisquer limites impostos pelo sistema normativo.

Queremos, sim, enfatizar que essas abstrações propiciam o implemento da praticabilidade tributária, mas deverão ser sopesadas com os diversos princípios e limitações à atividade impositiva que nossa rígida Constituição impõe.

\footnotetext{
${ }^{35}$ PONTES, Helenílson Cunha. O princípio da praticidade no Direito Tributário (substituição tributária, plantas de valores, retenções de fontes, presunções e ficções, etc): sua necessidade e seus limites. Revista Internacional de Direito Tributário, v. 2. Minas Gerais: Del Rey, julho/dezembro de 2004, p. 58. Como exemplo ele desenvolve o seguinte raciocínio: "Quando a Constituição diz que o Presidente da República poderá nomear para Ministro do Supremo Tribunal Federal alguém que tenha a idade superior a $\mathrm{X}$ anos, reputação ilibada e notório saber jurídico, tanto pode nomear o professor Eros Grau, quanto a professora Misabel, o professor Sacha, isso é um indiferente jurídico: qualquer um deles pode perfeitamente ir para o Supremo, porque preenchem um conceito. Aí, sim, há discricionariedade. Preenchidos os elementos do conceito, há discricionariedade". ${ }^{36}$ Sobre a possibilidade dos conceitos indeterminados em razão da praticabilidade: "O princípio da praticabilidade ainda pode contribuir para atenuação das exigências da determinabilidade do princípio da legalidade fiscal de ou outro modo, constituindose em suporte para o legislador utilizar conceitos indeterminados ou conceder faculdades discricionárias, o que de resto se verifica um pouco por toda a parte e que entre nós, tem diversas manifestações, seja na modalidade de atribuição de verdadeira discricionariedade, seja na modalidade de utilização de conceitos indeterminados tipo". CABAIS, José Casalta. O Dever Fundamental de Pagar Impostos - Contributo para a compreensão constitucional do estado fiscal contemporâneo. 3. ed. Coimbra: Almedina, 2012, p. 378.

${ }^{37}$ COSTA, Regina Helena. Praticabilidade e justiça tributária - Exequibilidade de Lei Tributária e Direitos do Contribuinte, São Paulo: Malheiros, 2007, p. 186.
} 
RICARDO LOBO TORRES ${ }^{38}$ chamou a atenção sobre este tema ao denunciar que o direito tributário "assiste à permanente tensão entre as técnicas de fechamento dos conceitos para fazer prevalecer o princípio da determinação (enumerações casuísticas e taxativas) e as de abertura, como o emprego dos conceitos indeterminados, das cláusulas gerais, cada vez mais comuns, e dos tipos".

Essa indeterminabilidade, que possibilita ao legislador uma maior amplitude na abrangência de situações da realidade social, demanda para a aplicação das normas tributárias, de técnicas de fechamento destes conceitos, por meio de padrões e esquemas generalizantes implementados com o uso das presunções e ficções. ${ }^{39}$

As presunções e ficções, como técnicas legislativas, auxiliam na eliminação das incertezas geradas pela complexidade do real, ao possibilitar a substituição de situações dúbias tanto na hipótese como na consequência das normas, por signos, que irão prover a redução simplificadora dos elementos do direito "por substituição do quantitativo ao qualitativo, no caso de presunções legais; por eliminação artificial das condições jurídicas das regras, nas ficções". ${ }^{40}$

As presunções e ficções estão plasmadas na construção da maior parte das nossas normas jurídicas, a começar da ficção de que "ninguém se escusa de cumprir a lei, alegando que não a conhece" ${ }^{41}$, que garante a operatividade de todo nosso sistema jurídico.

Outra característica importantíssima das presunções e ficções reside na possibilidade da dispensa da colheita de provas difíceis ou mesmo impossíveis em cada caso concreto, quando se aplica a lei tributária a milhares de contribuintes.

Nos dias atuais é impensável a ideia de inversão do ônus da prova ou mesmo na dispensa das provas das ocorrências dos fatos alegados no ato administrativo com base na presunção de sua legitimidade.

\footnotetext{
38 TORRES, Ricardo Lobo. O princípio da Tipicidade no Direito Tributário. Revista Eletrônica de Direito Administrativo Econômico, Salvador, Instituto de Direito Público da Bahia, no. 5, fev/mar/abr de 2006. Disponível na Internet: < http://www.direitodoestado.com.br>. Acesso em: 15 de fevereiro de 2013, p. 15.

${ }^{39}$ Misabel Derzi ao tratar do fenômeno da incidência no plano vertical assim doutrinou: "O objetivo não é analisar o fenômeno no plano horizontal, mas vertical. Tomando como base a hierarquia das normas, é útil questionar a validade da norma inferior que estabelece abstrações, tipos ou presunções com o objetivo de possibilitar a execução de norma hierarquicamente superior. Trata-se de investigar as esquematizações, as abstrações generalizantes (sejam tipos ou conceitos fechados) que têm como fim simplificar a execução das normas de tributação. O ângulo de análise aqui é diverso, pois se considera como relevante a relação entre norma exequente e norma a executar. A norma executiva contém, muitas vezes, presunções, ficções e esquemas (que, em geral, se convertem em conceitos fechados), em regra não autorizados pela norma superior, mas úteis à sua execução. A análise, que ora se faz, considera exatamente as esquematizações, abstrações e generalizações (tipificações e conceitualizações) que a norma inferior, ao executar a superior, em nome da praticidade, faz ou pode fazer. Por essa razão, exatamente naqueles ramos jurídicos, onde compete a órgão estatal executar a norma em massa, é que se coloca de forma mais aguda a questão da praticidade e de seus limites". DERZI, Misabel de Abreu MAChado. Direito tributário, direito penal e tipo, 2. ed. São Paulo: Revista dos Tribunais, 2008, p. 320.

${ }^{40}$ PAOLA, Leonardo Sperb de. Presunções e ficções no direito tributário. Belo Horizonte: Del Rey, 1997, p. 55.

${ }^{41}$ Art $3^{\circ}$ da Lei de Introdução ao Código Civil. Decreto-Lei 4.657, de 4 de Setembro de 1942.
} 
No lançamento tributário a autoridade administrativa tem o dever e não o ônus de provar o ato, vez que o "ônus é, por definição, disponível”. ${ }^{42}$

PAUlo DE BARros CARVALHO ${ }^{43}$ enfatiza que "na própria configuração oficial do lançamento, a lei institui a necessidade de que o ato jurídico administrativo seja devidamente fundamentado, o que significa dizer que o fisco tem que oferecer prova concludente de que o evento ocorreu na estrita conformidade da previsão genérica da hipótese normativa".

É o que também afirma PAULO AYRES BARRETO44 ao dizer que: "cabe à administração provar, de forma inequívoca, fazendo uso dos meios de prova em direito admitidos, os fatos que alega. Não logrando êxito nessa comprovação, o fato por ela alegado não subsiste como fato jurídico. É mero evento ou fato social, irrelevante para o direito”.

Reconhecida a importância da prova no lançamento tributário, como deve proceder a autoridade administrativa para, por exemplo, "provar" o valor venal, base de cálculo, de cada um dos milhares de imóveis no lançamento do IPTU? Como deve realizar a "prova" do valor de cada um dos milhões de veículos automotores no lançamento do IPVA? Como deverá "provar" ou "comprovar" para cada um dos milhões de brasileiros, as deduções na declaração do imposto de renda da pessoa física?

Nestes casos ilustrativos e em vários outros surge como solução as presunções, como meios indiretos de prova ${ }^{45}$, porquanto permitem considerar juridicamente existente um fato típico desconhecido, a partir de um fato indiciário ${ }^{46}$, utilizando-se um raciocínio dedutivo.

Pelo uso de técnicas presuntivas, o legislador e o aplicador buscarão padronizar, buscar valores médios, típicos, que normalmente ocorrem, de modo a facilitar o reconhecimento da ocorrência do fato jurídico tributário ou a base de cálculo e, consequentemente, a cobrança do tributo devido.

Em longa digressão, em sua monografia sobre as presunções, MARIA RITA FERRAGUT ${ }^{47}$ conclui que: "as presunções colaboram, também, para a eficácia da atividade arrecadatória, através da simplificação da arrecadação, nas hipóteses em que a prova direta é

\footnotetext{
${ }^{42}$ BORGES, José Souto Maior. Tratado de Direito Tributário Brasileiro - Lançamento Tributário. Vol. IV. Rio de Janeiro: Forense, 1981, p.107-108. O professor sublinha que o "dever que incumbe ao fisco de investigar a ocorrência do fato jurídico tributário é um dever de ofício".

${ }^{43}$ CARVALHO, Paulo de Barros. A prova no procedimento administrativo tributário. Revista de Direito Tributário, n. 34. São Paulo: Revista dos Tribunais, 1998, p. 107-108.

${ }^{44}$ BARRETO, Paulo Ayres. Imposto sobre a renda e preços de transferência. São Paulo: Dialética, 2001, p. 143.

45 "São denominadas provas diretas as que representam, de forma imediata, o evento, caracterizando seu relato linguístico. A expressão provas indiretas, por seu turno, é utilizada para referir à prova de acontecimentos diversos daquele que se pretende provar; mas cuja a existência confirma ou infirma o fato probando". TOMÉ, Fabiana Del Padre. A prova no direito tributário. São Paulo: Noeses, 2005, p. 92.

46 "Indício é todo vestígio, indicação, sinal, circunstância e fato conhecido apto a nos levar, por meio de raciocínio indutivo, ao conhecimento de outro fato, não conhecido diretamente". ${ }^{46}$ FERRAGUT, Maria Rita. Presunções no direito tributário. São Paulo: Dialética, 2001, p.50.

${ }^{47}$ FERRAGUT, Maria Rita. Presunções no direito tributário. São Paulo: Dialética, 2001, p.81.
} 
impossível ou muito difícil de ser produzida". Afirma que as presunções "realizam o princípio da praticabilidade" ao suprirem deficiências probatórias na "impossibilidade, ou da elevada dificuldade, de comprovar todos os elementos de uma dada situação fática”.

Feitas essas considerações, acreditamos ter demonstrado que as presunções e ficções por se constituírem condição indispensável para a operacionalização do direito e por sua íntima conexão com a praticabilidade, como ferramentas simplificadoras, deverão ser analisadas com maior profundidade.

\subsection{Presunções e Ficções}

Convencidos da importância do tema das presunções e ficções neste estudo, passaremos sem demora ao exame individualizado desses institutos, identificando suas espécies e a possibilidade de sua utilização em razão dos limites existentes em nosso ordenamento jurídico, bem como perquirir de que forma as presunções e ficções podem alterar, ou moldar as estruturas da norma tributária, para que a serviço da praticabilidade, destinem-se a facilitar a sua execução.

\subsubsection{Conceito de Presunções, Classificação e Espécies}

Como qualquer outro vocábulo "presunção" também padece de ambiguidade e vagueza. FLORENCE HARET ${ }^{48}$, em estudo profundo sobre o tema, denuncia para ele 89 acepções.

Realizando um corte metodológico dentre essas acepções, selecionamos aquelas que nos interessam mais de perto neste estudo: (i) presunção como técnica de apuração de tributo; e (ii) presunção como técnica de simplificação fiscal.

Na presunção como técnica de apuração de tributo, a autora ressalta que em razão da materialidade das hipóteses tributárias, muitas vezes torna-se difícil a determinação do quantum do tributo. Nestes casos "algumas presunções atuam no direito tributário como técnica de apuração, que, por métodos aproximados, e levando-se em conta outros signos indicativos de riqueza, determinam o valor devido pelo contribuinte ao fisco". ${ }^{4}$

Sobre esta técnica de apuração, fundamentada em presunções, voltaremos ao assunto mais adiante, sobre a denominação de padronizações.

\footnotetext{
${ }^{48}$ HARET, Florence. Teoria e Prática das Presunções no Direito Tributário. São Paulo: Noeses, 2011, p. 87-92.

${ }^{49}$ Ibidem, p. 89.
} 
A acepção das presunções como uma técnica de simplificação fiscal, refere-se, segundo a autora, "ao efeito de simplificação na sistemática fiscal que algumas presunções são aptas a proporcionar" ${ }^{5_{0}}$, revelando-se como na acepção anterior, seu aspecto pragmático.

O Simples Nacional e a substituição tributária para frente são exemplos citados de presunções como técnicas de simplificação fiscais, aos quais dedicaremos neste estudo um aprofundamento maior no capítulo destinado ao estudo de casos.

O legislador na missão de instituir os tributos elege signos de riqueza na hipótese de incidência, trazendo em si a presunção de que nestes fatos escolhidos existe alguma forma de renda ou capital a ser tributado.

A presunção da capacidade contributiva, com base na probabilidade de riqueza exteriorizada em determinadas coisas ou situações, permite-nos dizer que "a presunção em lei é própria de todos os tipos hipotéticos, está na base de toda previsão legal, instituindo legalmente a probabilidade como verdade ou como fato jurídico ele mesmo". ${ }^{51}$

Nos dizeres de ALFREDO BECKER ${ }^{52}$ :

A praticabilidade e a certeza da incidência das regras jurídicas tributárias, sempre induziu e, cada vez mais, induz o legislador a escolher, como elementos integrantes da hipótese de incidência, signos econômicos (fatos econômicos) ou signos jurídicos (fatos jurídicos), cuja existência faz presumir a existência de determinado gênero e espécie de renda ou de capital.

Segundo doutrina, a presunção pode ser definida como "o resultado do processo lógico mediante o qual do fato conhecido cuja existência é certa se infere o fato desconhecido cuja existência é provável". ${ }^{53}$

De maneira semelhante, PAULO DE BARROS CARVALHO ${ }^{54}$ define presunção como "o resultado lógico, mediante o qual do fato conhecido, cuja existência é certa, infere-se o fato desconhecido ou duvidoso, cuja existência é simplesmente provável”.

Como definição doutrinária, GILBERTO DE UlHOA CANTO"55 enuncia que "na presunção toma-se como sendo a verdade de todos os casos aquilo que é verdade da generalidade dos casos iguais, em virtude lei de frequência ou de resultados conhecidos, ou em decorrência da previsão lógica do desfecho".

\footnotetext{
${ }^{50}$ HARET, Florence. Teoria e Prática das Presunções no Direito Tributário. São Paulo: Noeses, 2011, p. 90-91.

${ }^{51}$ HARET, Florence. Teoria e Prática das Presunções no Direito Tributário. São Paulo: Noeses, 2011, p. 599.

52 BECKER, Alfredo Augusto. Teoria Geral do Direito Tributário. 5.ed.São Paulo: Noeses, 2010, p. 539.

${ }^{53}$ Ibidem, p. 542.

${ }^{54}$ CARVALHO, Paulo de Barros. A prova no procedimento administrativo tributário. Revista de Direito Tributário, $\mathrm{n}^{\circ} 34, \mathrm{p}$. 109.

${ }^{55}$ CANTO, Gilberto Ulhoa. Presunções no Direito Tributário. In: Martins, Ives Gandra da Silva (Coord). Caderno de Pesquisas Tributárias: presunções no direito tributário. Vol. 9. São Paulo: Resenha Tributária, CEEU, 1984, p. 3.
} 
Ou ainda como propugna LEONARDO SPERB DE PAOLA, “a presunção resulta do relacionamento entre dois fenômenos, os quais, na experiência, aparecem em íntima conexão, isto é, ocorrendo um, o mais das vezes sucederá o outro". ${ }^{56}$

Para MARIA RITA FERRAGUT ${ }^{57}$, "as presunções nada presumem juridicamente, mas prescrevem o reconhecimento jurídico de um fato provado de forma indireta". Como o fato real não pode ser atingido pelo direito, apenas a manifestação do evento, ela conclui que: “independentemente da prova ser direta ou indireta, o fato que se quer provar será ao máximo juridicamente certo e fenomenicamente provável. É a realidade jurídica impondo limites ao conhecimento jurídico".

A doutrina clássica ${ }^{58}$ classifica as presunções segundo dois critérios básicos: (i) quanto à previsão legal expressa; e (ii) quanto à força probatória.

Quanto à previsão legal expressa as presunções classificam-se em: (i) legais ou juris quando estabelecidas em leis; e (ii) simples, ou comuns ou hominis construídas pelo aplicador ou intérprete.

Quanto à força probatória, classificam-se em: (i) absolutas ou juris et de jure como aquelas que não admitem prova em contrário; (ii) relativas ou juris tantum que admitem provas, sem qualquer restrição, que infirmem a presunção; e (iii) mistas ou qualificadas por admitirem somente alguns meios de provas fixados em lei.

Várias são as críticas aplicáveis a esta classificação doutrinária das presunções, a começar da impossibilidade de formulação de um conceito jurídico unitário de presunção.

Não se pode falar juridicamente em uma categoria geral das presunções, que englobe todas as espécies apontadas na doutrina, apenas com o conceito genérico de que presunção seja o resultado de processo lógico da qual se infere um fato desconhecido de um fato desconhecido ${ }^{59}$. A adoção deste conceito muito lato de presunção reduz em muito sua utilidade para a ciência do direito.

Muitas são as críticas também pela classificação das presunções em relativas e absolutas, adotando-se o critério da possibilidade ou não de admissão de provas em contrário.

\footnotetext{
${ }^{56}$ PAOLA, Leonardo Sperb de. Presunções e ficções no direito tributário. Belo Horizonte: Del Rey, 1997, p. 60.

${ }^{57}$ FERRAGUT, Maria Rita. Presunções no direito tributário. São Paulo: Dialética, 2001, p. 63.

${ }^{58}$ BECKER, Alfredo Augusto. Teoria Geral do Direito Tributário. 5.ed.São Paulo: Noeses, 2010, p. 542-543.

${ }^{59}$ PAOLA, Leonardo Sperb de. Presunções e ficções no direito tributário. Belo Horizonte: Del Rey, 1997, p. 60. Reproduzimos seu raciocínio: "O problema fundamental do conceito de que tratamos é que envolve, com um mesmo rótulo, institutos jurídicos que são essencialmente diferentes. Com efeito, presunções legais absolutas, presunções legais relativas e presunções simples têm naturezas jurídicas perfeitamente distintas. As presunções legais absolutas, por exemplo, estão mais próximas das ficções (para alguns juristas são iguais a elas) do que das demais presunções. Ambas têm a ver com a formulação de regras jurídicas de fundo. Já as presunções legais relativas e as simples também pouco têm em comum, afora o fato de se relacionarem-se com questões probatórias. Enfim, o conceito de presunção, da forma ampla como foi enunciado, é de pouca utilidade para o jurista. Pelo contrário, é mais apto a gerar confusões e equívocos, pois que engloba fenômenos inconfundíveis. As espécies de presunção, sob o prisma jurídico, não têm traços em comum, não pertencem a um mesmo gênero".
} 
Enquanto nas presunções legais relativas ${ }^{60}$ busca-se provar por um indício ${ }^{61}$ a existência de um fato desconhecido, nas presunções absolutas não há tratamento de matéria probatória, porquanto trazem verdadeiras regras dispositivas de direito substantivo. ${ }^{62}$

Nas presunções absolutas o raciocínio indutivo de que, por um indício, prova-se a existência de um fato desconhecido ocorre na fase pré-jurídica. O legislador ao observar o que ordinariamente acontece elabora uma norma que torna absoluto ou constante, independentemente de provas em contrário, o vínculo entre um fato de existência comprovada e um outro fato. ${ }^{63}$

Tal vinculação absoluta é que a desqualifica como presunção, "o fato jurídico que deveria ser meramente processual transforma-se em fato jurídico material, deixando a presunção, com isso, de contemplar uma probabilidade para veicular uma verdade jurídica necessária". ${ }^{64}$

BECKER $^{65}$ ressalta que muitas regras jurídicas positivadas passaram por uma evolução histórica: iniciaram-se como presunções simples, evoluíram posteriormente para presunções legais e, finalmente, como último estágio da evolução, são convertidas em regras jurídicas dispositivas de direito substantivo.

Alinhamo-nos com a ideia $^{66}$ de que as presunções absolutas, sob o prisma normativo, constituem-se em verdadeiras regras remissivas ampliando o âmbito de aplicação de uma norma jurídica a novos casos, ou em alguns casos, restritivas da hipótese, ou ainda, nem ampliação nem redução, mas alteração das consequências jurídicas da norma a que está vinculada. ${ }^{67}$

\footnotetext{
${ }^{60}$ Dentre as presunções relativas, estariam as mistas ou qualificadas. Na opinião de Maria Rita Ferragut, o critério classificativo que reside no fato de só admitir alguns tipos de provas pré-estabelecidos, sucumbe perante o princípio constitucional da ampla defesa e, para todos os efeitos, tal limitação deve ser considerada inconstitucional. FERRAGUT, Maria Rita. Presunções no direito tributário. São Paulo: Dialética, 2001, p. 65. Também pela limitação na prova em contrária, Paulo Ayres Barreto repudia em quaisquer hipóteses a utilização das presunções legais mistas. BARRETO, Paulo Ayres. Imposto sobre a renda e preços de transferência. São Paulo: Dialética, 2001, p. 150.

${ }^{61}$ Importante destacar que presunção e indício não se confundem. A presunção "é o resultado do procedimento lógico fundado no indício. O indício é o fato conhecido que se relaciona com o fato que deve ser provado, é a base do raciocínio presuntivo. O indício é o meio de prova propriamente dito, ou, em outras palavras, a prova em sentido objetivo. A presunção tem mais a ver com a convicção, a prova em sentido subjetivo". PAOLA, Leonardo Sperb de. Presunções e ficções no direito tributário. Belo Horizonte: Del Rey, 1997, p. 73. Segundo Roque CARAZZA: "por força do princípio da segurança jurídica, a utilização dessas mentiras técnicas só pode decorrer de norma jurídica expressa". CARRAZZA, Roque Antonio. Curso de Direito Constitucional Tributário. 22. ed. São Paulo: Malheiros, 2006, p. 455.

${ }^{62}$ BECKER, Alfredo Augusto. Teoria Geral do Direito Tributário. 5.ed.São Paulo: Noeses, 2010, p. 544 e ss.

${ }^{63}$ Leonardo Sperb de Paola citando Geny alude "que as presunções absolutas têm, em regra, sua origem em presunções simples, que, depois são transformadas em normas de fundo pelo legislador". PAOLA, Leonardo Sperb de. Presunções e ficções no direito tributário. Belo Horizonte: Del Rey, 1997, p. 61.

${ }^{64}$ FERRAGUT, Maria Rita. Presunções no direito tributário. São Paulo: Dialética, 2001, p. 64.

${ }^{65}$ BECKER, Alfredo Augusto. Teoria Geral do Direito Tributário. 5.ed.São Paulo: Noeses, 2010, p. 546.

${ }^{66}$ PAOLA, Leonardo Sperb de. Presunções e ficções no direito tributário. Belo Horizonte: Del Rey, 1997, p. 62-63.

${ }^{67}$ Essa ideia de que através da incidência da norma presuntiva sobre uma outra norma poderá alterar o consequente de outra norma nos será muito útil, quando analisarmos a padronização da base de cálculo dos impostos pela praticabilidade.
} 
Essas normas são ditas remissivas pelo fato de não terem uma existência jurídica independente; para adquirir um sentido jurídico necessitam de uma outra norma à qual faz a remissão.

A classificação de presunções legais e simples, quanto ao critério da previsão legal expressa, também não resiste a uma análise mais profunda. Ambas as presunções só serão relevantes para o direito quando vertidas em normas, ou seja, quando forem veiculadas em linguagem proposicional competente.

As presunções simples ou hominis são o resultado de um raciocínio lógico "realizado pelo aplicador da norma, que, a partir do conhecimento de indícios, da inexistência de provas em sentido contrário a eles, e da relação de implicação estabelecida segundo o que ordinariamente acontece, forma sua convicção" ${ }^{6}$, vertendo a partir dela uma norma individual e concreta, resultado deste raciocínio presuntivo.

Conforme acentua MARIA RITA FERRAGUT ${ }^{69}$, todas as presunções existentes em nosso ordenamento jurídico são legais ${ }^{70}$, sejam em enunciados gerais e abstratos (legais), sejam em individuais e concretos (hominis) como produto do ato de aplicação das gerais e abstratas presuntivas.

Na mesma linha FLORENCE HARET"1 ao afirmar que "o caráter legal encontra-se em todas as presunções, afinal, se a ordem posta só cria realidade mediante norma, nenhuma presunção refoge a esta regra, devendo vir enunciada em linguagem proposicional competente. Sendo assim, toda presunção é também legal”.

Sintetizando, podemos afirmar, com base na doutrina exposta, que a natureza jurídica das presunções será sempre considerada normativa, seja através de norma geral e abstrata nas presunções legais, seja através de norma individual e concreta nas presunções hominis.

\footnotetext{
6868 FERRAGUT, Maria Rita. Presunções no direito tributário. São Paulo: Dialética, 2001, p. 75.

${ }^{69}$ FERRAGUT, Maria Rita. Presunções no direito tributário. São Paulo: Dialética, 2001, p. 65-66.

${ }^{70}$ Neste sentido: "o caráter legal encontra-se em todas as presunções, afinal, se a ordem posta só cria realidade mediante norma, nenhuma presunção refoge a esta regra, devendo vir enunciada em linguagem proposicional competente. Sendo assim, toda presunção é também legal". HARET, Florence. Teoria e Prática das Presunções no Direito Tributário. São Paulo: Noeses, 2011, p. 392.

${ }^{71}$ HARET, Florence. Teoria e Prática das Presunções no Direito Tributário. São Paulo: Noeses, 2011, p. 392. A autora firma a posição que todas as presunções são normas, mas com força ou função diversas no sistema jurídico. "Umas farão irromper tipo factual abstrato, prescrita em lei na forma de conteúdo hipotético geral; outras atuarão como norma introduzida, constituindo o fato em seu consequente. Algumas ainda cumpriram o papel de norma introdutora - geral e concreta - inserindo a norma constitutiva do fato em seu consequente. Nas duas primeiras teremos verdadeiras hipóteses, lá se encontrando as presunções ditas legais ou de conteúdo hipotético. Nas terceiras é que se acham as presunções como meios de prova, de onde faremos a correlação necessária com as presunções exaradas pelo aplicador do direito, também conhecidas como do tipo humana ou hominis. Agora, estando no campo das provas, as presunções, em sua totalidade, funcionam como formas ou técnicas de constituição do fato jurídico". Ibidem, p. 159-160.
} 


\subsubsection{Conceito de Ficção}

Na definição de ALFREDO BECKER ${ }^{72}$, a ficção legal é criada pela regra jurídica "quando, baseando-se no fato conhecido cuja existência é certa, impõe a certeza jurídica da existência do fato desconhecido cuja existência é improvável (ou falsa) porque falta correlação natural de existência entre estes dois fatos".

Partindo desta definição, ele afirma que a diferença entre ficção e presunção está em que: "a verdade jurídica imposta pela lei, quando se baseia numa provável (ou certa) falsidade é ficção legal, quando se fundamenta numa provável veracidade é presunção legal". ${ }^{73}$

Segundo o doutrinador "a distinção entre a presunção e a ficção existe apenas no plano pré-jurídico, enquanto serviam de elemento intelectual ao legislador que estava construindo a regra jurídica", porquanto "ao penetrarem no mundo jurídico por intermédio da regra jurídica, ambas entram como verdades (realidades jurídicas)". ${ }^{74}$

A diferença entre os institutos foi objeto de estudo de PONTE DE MIRANDA ${ }^{75}$ :

[...] as ficções são mais do que presunções legais, ainda absolutas. A ficção enche de artificial o suporte fáctico; a presunção legal apenas tem como acontecido ou não acontecido, o que talvez não aconteceu ou aconteceu. A ficção tem no suporte fáctico elemento de que não se poderia induzir a situação que ela prevê. Daí, nada se presumir, quando se elabora ficção.

A ficção pode ser definida, conforme CARRAZZA76, como "um artifício do legislador, que transforma uma impossibilidade material numa possibilidade de natureza jurídica (...) é uma criação do legislador, que faz nascer uma verdade jurídica diferente da verdade real".

De forma contrária LUís EDUARDo SCHOUERI ${ }^{77}$ entende que o emprego da ficção não implica em contradizer verdades jurídicas preestabelecidas. Ele entende ser uma norma remissiva "através da qual o legislador determina que se aplique, a dada hipótese de incidência (fingierter Tatbestand, ou hipótese ficta), determinadas sanções previamente definidas para outra situação (Fiktionsbasis, ou base de ficção)".

\footnotetext{
${ }^{72}$ BECKER, Alfredo Augusto. Teoria Geral do Direito Tributário. 5.ed.São Paulo: Noeses, 2010, p. 544.

${ }^{73}$ BECKER, Alfredo Augusto. Teoria Geral do Direito Tributário. 5.ed.São Paulo: Noeses, 2010, p. 543.

${ }^{74}$ Ibidem, p. 544.

${ }^{75}$ PONTES DE MIRANDA. Tratado de direito privado. 2. ed. Rio de Janeiro: Borsoi, 1954. Parte Geral, t.III, p. 446.

${ }^{76}$ CARRAZZA, Roque Antonio. Curso de Direito Constitucional Tributário. 22. Ed. São Paulo: Malheiros, 2006, p. 449.

${ }^{77}$ SCHOUERI, Luís Eduardo. Distribuição Disfarçada de Lucros. São Paulo: Dialética, 1996, p. 104. Com apoio na doutrina de Berhöf ele sublinha que "a ficção serve para simplificação e comodidade do legislador, já que o legislador atingiria iguais resultados se, em vez de empregar a ficção, tivesse repetido, para a hipótese ficta, todas as sanções antes definidas para a base da fíção ou se, simplesmente, tivesse feito uma remissão expressa aos dispositivos legais desejados". (Grifei). Ibidem, p. 106.
} 
Para BRANDÃO MACHADO ${ }^{78}$ as ficções também não são nada mais do que uma forma especial de remissão que podem tanto equiparar fatos como limitar suas consequências.

Nesta linha, a abalizada afirmação de KARL LARENZ"9 de que a "ficção jurídica consiste na equiparação voluntária de algo que se sabe desigual - por vezes também em pôr como desigual o que se sabe igual... As ficções legais têm normalmente por fim a aplicação da regra dada para um fato previsto (F1) a outro fato previsto (F2). São então encobertas remissões".

Esse caráter remissivo das ficções também é apontado por LEONARDO SPERB DE PAOLA $^{80}$, que entende a ficção como "um procedimento de técnica legislativa que amplia em relação a determinados fatos o regime previsto para outros. É um modo abreviado, sintético, de criação de normas jurídicas".

JosÉ PÉREZ DE AYALA ${ }^{81}$ também entende que as ficções não criam mentiras ou falseiam a realidade extrajurídica, mas encerram técnicas que possibilitam ao legislador atribuir efeitos jurídicos a determinadas realidades, ignorar a natureza real das coisas, criando assim uma verdade jurídica distinta da realidade social.

Em realidade a ideia de que a ficção como norma jurídica distorce a realidade ou baseia-se numa falsidade é muito frágil e passível de críticas.

Em primeiro lugar, as normas jurídicas são proposições prescritivas que não têm a valência de verdadeiras ou falsas, mas sim de válidas ou inválidas por pertencerem a um determinado sistema jurídico e por terem sido elaboradas por órgãos legitimados mediante os procedimentos previamente estabelecidos. ${ }^{82}$

Em segundo lugar, as leis da natureza pertencem ao mundo do ser, no qual os fatos se relacionam com as consequências numa relação de causa e efeito regida pelo princípio da

\footnotetext{
${ }^{78}$ MACHADO, Brandão. Distribuição disfarçada de lucros no Direito Comparado. In: Nogueira, Ruy Barbosa (coord.). Estudos Tributários - em homenagem a Rubens Gomes de Souza. São Paulo: Resenha Tributária, 1974, p. 181.

${ }^{79} \mathrm{O}$ autor detalha ainda mais: "Em vez de ordenar, as consequências jurídicas de F1 vigoram também em F2 (ou: quando se verifica F2 aplicam-se as mesmas regras que no caso F1), a lei 'finge' que F2 é um caso de F1 (F2 é havido como F1, F2 'vale' F1). Como a lei não contém declarações, mas sim ordenações de vigência, temos aqui não a afirmação de que F2 seja 'na realidade' idêntico a F1 ou um caso de F1, mas a instrução de que no caso F2 se produzem as mesmas consequências jurídicas que no caso F1. Só para alcançar este objetivo é que F2 deve ser 'considerado' (por quem aplica a lei) 'como se' fosse F1. Se, pelo contrário, F2 deve ser considerado como não sendo um caso de F1, embora de fato o seja, então quer a lei por esse meio excluir para F2 as consequências jurídicas de F1 (que, senão, se produziriam) - trata-se então de uma encoberta restrição". LARENZ, Karl. Metodologia da ciência do direito. Tradução de José de Souza Brito e José Antonio Veloso. Lisboa: Fundação Calouste Gulbenkian, 1974, p. 240-241.

${ }^{80}$ PAOLA, Leonardo Sperb de. Presunções e ficções no direito tributário. Belo Horizonte: Del Rey, 1997, p. 78.

${ }^{81}$ PÉREZ DE AYALA, José Luis. Las ficciones en el derecho tributário. Madrid: Editorial de Derecho Financiero, 1970, p. $15-16$.

82 “As normas jurídicas proposições prescritivas que são, têm sua validade própria. Delas não se pode dizer que sejam verdadeiras ou falsas, valores imanentes às proposições descritivas da Ciência do Direito, mas as normas jurídicas serão sempre válidas ou inválidas, com referência a um determinado sistema ' $S$ '. E ser norma válida quer significar que mantém relação de pertinencialidade com o sistema ' $\mathrm{S}$ ', ou que nele foi posta por órgão legitimado a produzi-la, mediante procedimento estabelecido para esse fim”. CARVALHO, Paulo de Barros. Curso de Direito Tributário. 17. ed. São Paulo: Saraiva, 2005. p. 81-82.
} 
causalidade física, enquanto as leis jurídicas habitam o mundo do dever ser, no qual o fato jurídico está vinculado aos seus efeitos pelo princípio da imputação deôntica.

No mundo do dever ser "é o legislador que imputa certas consequências jurídicas aos eventos que ele livremente escolhe, no tecido das relações sociais" ${ }^{83}$ e, portanto, inexiste "no universo das proposições jurídicas, necessidade lógica ou factualmente fundada de a hipótese implicar a tese ou consequência. É a própria norma que põe o vinculum, é a fonte formal do Direito que, fundando-se num ato de valoração, estatui como devendo ser que a hipótese implique a consequência". ${ }^{84}$

É o direito como objeto cultural que se manifesta pela linguagem própria das prescrições normativas e que não se confundem com a linguagem da realidade social. Sendo linguagem, cria sua própria realidade. ${ }^{85}$

Considerando então as ficções como normas remissivas, o que as diferencia das presunções absolutas que também se caracterizam como tal?

Para PÉREZ DE AYALA ${ }^{86}$ na presunção a lei atribui a certos fatos materiais (A), um efeito relacionado com outro fato (B), que empiricamente o acompanha. $\mathrm{Na}$ ficção, isto não acontece, pois o legislador com base em fato conhecido de existência certa (A) impõe as consequências de outro fato (B) não conhecido, de existência improvável ou falsa, em razão de não haver uma relação natural entre os fatos (A) e (B). Conclui o jurista que a ficção, por criar em princípio seu objeto jurídico, serve a exigências valorativas do direito, enquanto a presunção por criar uma relação causal entre duas realidades ou fatos naturais, apresenta um objeto mais limitado, facilitando o estabelecimento jurídico de um fato quando sua prova é obstaculizada.

A resposta pode ser encontrada no vínculo entre os fenômenos equiparados. $\mathrm{Na}$ presunção absoluta existe um vínculo natural entre dois fenômenos, que foi positivada pela observação do que geralmente acontece. Na ficção, esse vínculo natural inexiste, sendo de cunho unicamente normativo.

\footnotetext{
${ }^{83}$ CARVALHO, Paulo de Barros. Fundamentos Jurídicos da Incidência Tributária. 8. ed.. São Paulo: Saraiva, 2010 , p. 76. ${ }^{84}$ VILANOVA, Lourival. As Estruturas Lógicas e o Sistema do Direito Positivo. 3a . edição. São Paulo: Noeses, 2005 , p.92. ${ }^{85}$ Neste sentido: “Cada língua é um mundo diferente, cada língua é um mundo inteiro, e diferente de toda outra língua. [...] não há realidade sem língua". FLUSSER, Vilém. Língua e realidade. 3a. ed. São Paulo: Annablume, 2007, p. 128 e 202, ou ainda: "O conhecimento pressupões a existência de linguagem. A realidade do ser cognescente caracteriza-se exatamente por esse conhecimento do mundo, constituído mediante linguagem. Não é possível conhecermos as coisas tal como se apresentam fisicamente, fora dos discursos que a elas se referem. Por isso, nossa constante afirmação de que a linguagem cria ou constitui a realidade". TOMÉ, Fabiana Del Padre. A prova no direito tributário. São Paulo: Noeses, 2005, p. 6.

${ }^{86}$ PEREZ DE AYALA, Jose Luis; GONZALEZ, Eusebio. Curso de Derecho Tributario. Tomo I. $6{ }^{\text {a }}$. ed. Madri: Editoriales de Derecho Reunidas, 1991, p. 357.
} 
Como importante consequência dessa distinção, a extensão da abrangência do regime jurídico ${ }^{87}$ será maior ou menor, caso se trate de uma presunção absoluta ou de uma ficção.

Nas presunções absolutas, em razão deste vínculo natural, “o aplicador está autorizado a considerar a remissão de forma bastante ampla, isto é, atribuir à hipótese de fato nela prevista a maior parte das consequências jurídicas ligadas à hipótese de fato da norma à qual se faz remissão, quando não todas". ${ }^{88}$

Nas ficções, isto não ocorre, a remissão "não abarca a totalidade do regime jurídico existente, mas apenas aqueles seus aspectos que, em vista dos fins e dos valores em jogo, são relevantes para a equiparação". ${ }^{89}$

Das exposições doutrinárias apresentadas, podemos resumidamente dizer que as ficções são normas de natureza remissiva, cuja remissão não está baseada numa relação empírica entre os fatos, como nas presunções absolutas, mas em outras razões consideradas importantes pelo legislador para equiparar os regimes jurídicos preexistentes.

\subsubsection{Funções e Utilizações das Presunções e Ficções na tributação}

É despiciendo ressaltarmos a importância das presunções e ficções no direito tributário, bastando observar que as hipóteses de incidência tributária são construídas como descrição abstrata de fatos signo-presuntivos de riqueza.

Antes de perquirir a possibilidade e os limites à utilização de presunções e ficções no direito tributário, iniciaremos pela análise das funções que elas cumprem genericamente no nosso sistema jurídico.

Dentre as funções primordiais que cumprem as presunções e ficções, a doutrina destaca $^{90}$ a simplificação da complexidade inerente ao direito, o combate à sonegação, e o aumento da eficácia na arrecadação, que nos interessa mais de perto neste estudo ${ }^{91}$.

\footnotetext{
87 “As normas remissivas, ao serem aplicadas, podem levar a resultados indesejados: a utilização de todas as consequências jurídicas do regime ao qual se fez remissão, pela plena equiparação, quando o que se tinha em vista eram apenas algumas regras, alguns traços do regime jurídico". PAOLA, Leonardo Sperb de. Presunções e ficções no direito tributário. Belo Horizonte: Del Rey, 1997, p. 80-81.

${ }^{88}$ PAOLA, Leonardo Sperb de. Presunções e ficções no direito tributário. Belo Horizonte: Del Rey, 1997, p. 81.

${ }^{89}$ PAOLA, Leonardo Sperb de. Presunções e ficções no direito tributário. Belo Horizonte: Del Rey, 1997, p. 81.

${ }^{90}$ Neste sentido: FERRAGUT, Maria Rita. Presunções no direito tributário. São Paulo: Dialética, 2001, p.81; PAOLA, Leonardo Sperb de. Presunções e ficções no direito tributário. Belo Horizonte: Del Rey, 1997, p. 98-112.

${ }^{91}$ Vale destacar a advertência de que: "A despeito da invocação de perseguição de fins legítimos, como o combate à sonegação e agilização da arrecadação, o emprego de presunções deve ser efetuado com extrema cautela, para que não resultem vulnerados os princípios de proteção ao contribuinte, especialmente os da segurança jurídica e da legalidade, tanto no que tange à instituição
} 
Conforme LeONARdo SPERB DE PAOLA ${ }^{92}$, todo instrumental técnico utilizado pela administração fazendária para mensurar a riqueza tributável está assentado pelo uso de presunções e ficções, citando como exemplos, dentre outros, os métodos objetivos de estimação da base de cálculo, pautas fiscais e a substituição tributária.

Ele destaca que para atingir esse objetivo, além de as ficções, todas as modalidades de presunção são empregadas, mas com a ressalva de que as presunções legais relativas são as mais adequadas por permitirem ao contribuinte contestar desvios e abusos que extrapolam por demais sua capacidade contributiva individualmente considerada. As presunções simples, conclui, prestam-se melhor no combate à sonegação fiscal ${ }^{93}$.

A doutrina destaca também a função de economia legislativa para comodidade do legislador proporcionada pelas presunções absolutas e ficções.

Como vimos, as presunções absolutas e as ficções têm natureza de normas remissivas, ampliando, na maioria das vezes, o âmbito de aplicação de uma norma jurídica, ao equiparar dois fatos a um mesmo consequente.

Sendo assim, ambos os institutos atendem aos objetivos de economia legislativa, ao equiparar uma nova figura jurídica a um fato já previsto anteriormente ${ }^{94}$. O legislador pode em lugar de prescrever que a norma x, aplicável ao fato a, deva ser aplicada também ao fato b, equiparar o fato $\mathrm{b}$ ao fato a, de modo que, uma vez equiparados, ambos sejam regidos pela mesma norma. ${ }^{95}$

YONNE DOLÁCIO DE OLIVEIRA ${ }^{96}$ declara essa função de economia legislativa como sendo respeito à tradição: "desejando manter a lei aparentemente intacta, o legislador obtém ampliação ou limitação declarando (incorretamente do ponto de vista jurídico) que o fato agora legislado é igual à hipótese de fato regulado na lei", ou ainda como comodidade "porque o legislador serve-se de ficção definitória quando poderia alcançar o mesmo resultado através de uma definição".

Encontramos ainda nas presunções absolutas e ficções a função de exercerem um importante papel no desenvolvimento e aceitação das mudanças jurídicas, ao evitar a quebra abrupta de continuidade do sistema, por permitir, pelo menos aparentemente, uma mudança

de tributos quanto no que se refere à aplicação de sanções”. COSTA, Regina Helena. Praticabilidade e justiça tributária Exequibilidade de Lei Tributária e Direitos do Contribuinte. São Paulo: Malheiros, 2007, p. 164.

${ }^{92}$ Leonardo Sperb de. Presunções e ficções no direito tributário. Belo Horizonte: Del Rey, 1997, p. 102.

93 Ibidem, p. 103.

${ }^{94}$ SCHOUERI, Luís Eduardo. Distribuição Disfarçada de Lucros. São Paulo: Dialética, 1996, p. 106.

${ }^{95}$ MACHADO, Brandão. Distribuição disfarçada de lucros no Direito Comparado. In: Nogueira, Ruy Barbosa (coord.). Estudos Tributários - em homenagem a Rubens Gomes de Souza. São Paulo: Resenha Tributária, 1974, p. 181.

96 OLIVEIRA, Yonne Dolácio de. Presunções no Direito Tributário. In: Martins, Ives Gandra da Silva (Coord). Caderno de Pesquisas Tributárias: presunções no direito tributário. Vol. 9. São Paulo: Resenha Tributária, CEEU, 1984, p. 369. 
gradual ao associar o novo ao velho, ou "com o enquadramento do novo em formas preexistentes". ${ }^{97}$

Essa função de permitir dissimular a entrada no sistema de novos valores e princípios é de suma importância para a praticabilidade. Como já deixamos assentado, a praticabilidade que vem sendo impulsionada por demandas externas, que refogem da análise puramente normativa do direito, implica cada vez mais no abandono da análise exaustiva individual nos fatos concretos.

Esta aplicação em massa traz como consequência o choque da praticabilidade com outros princípios já consagrados em nosso ordenamento. Essa ruptura, pensamos, poderá a princípio ser amenizada pelo uso das presunções absolutas e ficções, que conforme a melhor doutrina, permitem uma mudança gradual de maneira a garantir a continuidade do sistema.

Neste sentido, cabe destacar a importantíssima desaprovação de ESSER, citada por YONNE DOLÁCIO DE OLIVEIRA ${ }^{98}$, quando a ficção é "meio de ruptura secreta e de sabotagem de princípios superiores". A autora alerta que no motivo relevante de "encobrir a ruptura de um princípio que se entende não comportar limitação", há o perigo de que a ficção "esquecendo ou desatenta à diferença real entre as duas hipóteses equiparadas, ultrapasse a medida razoável e objetivamente defensável".

As presunções legais relativas, voltadas principalmente à matéria probatória, têm por objetivo primordial facilitar o ônus probatório das partes, sem que com isso, conforme deixamos registrado, queira significar que haja inversão do ônus da prova.

$\mathrm{Na}$ esfera tributária, em determinados impostos aplicados a milhares de contribuintes, repetimos, não há como a administração investigar exaustivamente cada caso concreto, "provando" a riqueza individual a ser tributada, justificando a utilização dessas presunções que "aliviam” o ônus probatório para o fisco.

Por tratar de matéria probatória, parte relevante da doutrina ${ }^{99}$ defende que as presunções relativas são normas de direito formal ou adjetivo, o que implicaria em diferentes limites e princípios à sua aplicação, mas a sua natureza jurídica é matéria tormentosa.

\footnotetext{
${ }^{97}$ PAOLA, Leonardo Sperb de. Presunções e ficções no direito tributário. Belo Horizonte: Del Rey, 1997, p. 85.

98 OLIVEIRA, Yonne Dolácio de. Presunções no Direito Tributário. In: Martins, Ives Gandra da Silva (Coord). Caderno de Pesquisas Tributárias: presunções no direito tributário. Vol. 9. São Paulo: Resenha Tributária, CEEU, 1984, p. 369.

${ }^{99}$ Neste sentido: "[...] podemos entender que as presunções são normas especiais referentes ao ônus da prova já que, na presença das hipóteses descritas pelo legislador, deve o juiz considerar o fato incerto descrito pelo legislador como ocorrido, cabendo à outra parte, se for o caso, comprovar sua inocorrência". SCHOUERI, Luís Eduardo. Distribuição Disfarçada de Lucros. São Paulo: Dialética, 1996, p. 117; ou: "Entendemos que as presunções, em todas as acepções por nós adotadas, têm natureza processual probatória, a elas sendo sempre aplicáveis os princípios constitucionais da ampla defesa e contraditório, dentre outros. Consistem em meios de prova indiciária, subsidiária, indireta, divergindo das hipóteses em que, na definição do fato jurídico ou da base de cálculo, intervêm ficções legais ou "presunções absolutas', enunciado jurídico de direito substantivo". FERRAGUT, Maria Rita. Presunções no direito tributário. São Paulo: Dialética, 2001, p. 50; ou: "Constituem, em síntese, regras jurídicas ligadas à formação da prova, que obrigam ao aplicador ter por certo um fato - com a denotação ou qualidade
} 
O direito material ou substantivo, segundo ESTEVÃo HORVARTH"100, "regula a existência orgânica do tributo, isto é, os direitos e deveres que emergem da relação jurídica tributária, com relação ao seu objeto, a seus titulares - sujeitos ativos e passivos - e à sua configuração estrutural", enquanto o direito formal ou adjetivo "se ocupa do procedimento de atuação do tributo, é dizer, dos procedimentos necessários à determinação, tutela jurídica e cobrança do tributo".

Cabe a ressalva de que essa distinção em normas jurídicas de direito formal e normas jurídicas de direito material tem efeito meramente didático, quando se tem em conta que o direito, por princípio, é uno e indecomponível ${ }^{101}$, mas que se mostra útil para o estudo das normas com diferentes particularidades e peculiaridades. ${ }^{102}$

PAUlo Ayres BARRETO ${ }^{103}$ contesta, de forma convincente, a assertiva de que as presunções legais relativas são sempre normas jurídicas de direito adjetivo.

Conforme doutrina, a norma em sentido estrito é composta de dois enunciados: o que estabelece a presunção relativa ${ }^{104}$; e o que admite a possibilidade de prova em contrário. $\mathrm{O}$ consequente desta norma só irá ocorrer se os dois fatos previstos nos enunciados ocorrerem, ou como ele mesmo afirma:

Inexiste velocidade distinta para incidência dos dois enunciados. A regra-matriz de incidência tributária é o resultado da conjugação do enunciado, que estabelece a presunção relativa, com aquele outro que admite a prova em contrário. $\mathrm{O}$ ato de aplicação do direito, seja pelo particular, seja pela autoridade administrativa, a norma individual e concreta por tais pessoas posta no sistema, haverá de considerar a conjugação dos dois enunciados.

Nestes casos, o fato jurídico tributário só será constituído se ocorrer o fato jurídico presumido e não houver prova em contrário. Essas presunções relativas têm natureza jurídica de direito material ou substantivo.

\footnotetext{
que lhe atribue a lei - quando impossível verificar-se, pelos instrumento usuais de prova, a sua não ocorrência, ou a sua ocorrência em modo diverso". BARRETO, Aires Fernandino; GIARDINO, Cléber. Presunções no Direito Tributário. In: Martins, Ives Gandra da Silva (Coord). Caderno de Pesquisas Tributárias: presunções no direito tributário. Vol. 9. São Paulo: Resenha Tributária, CEEU, 1984, p. 369; ou ainda: "As presunções legais relativas não podem ser consideradas regras de Direito Material, porque dispõem sobre prova do fato relevante, ou de um dos fatos relevantes, para a solução da lide. $O$ destinatário dessa norma é o magistrado". PAOLA, Leonardo Sperb de. Presunções e ficções no direito tributário. Belo Horizonte: Del Rey, 1997, p. 68.

${ }^{100}$ HORVATH, Estevão. Lançamento Tributário e “Autolançamento". 2a . ed. São Paulo: Quartier Latin do Brasil, 2010 , p.34. ${ }^{101}$ BARRETO, Paulo Ayres. Imposto sobre a renda e preços de transferência. São Paulo: Dialética, 2001, p. 143.

102 HORVATH, Estevão. Lançamento Tributário e "Autolançamento". 2a . ed. São Paulo: Quartier Latin do Brasil, 2010 , p.37. ${ }^{103}$ BARRETO, Paulo Ayres. Imposto sobre a renda e preços de transferência. São Paulo: Dialética, 2001, p. 146-147.

${ }^{104}$ Neste sentido : "Como proposição prescritiva, a presunção é norma jurídica deonticamente incompleta (norma lato sensu), de natureza probatória que, a partir da comprovação do fato diretamente provado (fato indiciário, fato diretamente conhecido, fato implicante), implica juridicamente o fato indiretamente provado (fato indiciado, fato indiretamente conhecido, fato implicado)" e como tal "não basta em si mesma para formar uma unidade mínima de significação do deôntico, haveremos de defini-la como sendo o conteúdo de um enunciado prescritivo geral e abstrato, expedido pelo legislador, ou individual e concreto, expedido pelo agente competente quando do ato de aplicação". FERRAGUT, Maria Rita. Presunções no direito tributário. São Paulo: Dialética, 2001, p. 62-63.
} 
Há, entretanto, situações em que o ordenamento prevê a incidência da norma tributária presuntiva e a consequente constituição do crédito em momento anterior àquele em que a produção da prova em contrário é permitida. Nestas ocasiões estaremos diante de presunções relativas de natureza jurídica de direito adjetivo ou formal.

Com esse raciocínio, o professor PAULO AYRES BARRETO conclui que "nesses específicos casos, no momento da constituição do crédito, inexistindo possibilidade de apresentação de prova em contrário, estaremos diante de ficção ou presunção absoluta". ${ }^{105}$ Quando em momento posterior a prova for admitida, "exsurge outra norma, que em cálculo relacional com a primeira poderá (ou não) eliminar os seus efeitos". ${ }^{106}$

Sobre essa "aparente" inadmissibilidade de provas já discorreu PONTES DE MIRANDA $^{107}$, ao enfatizar que "se a regra não estivesse escrita, a mesma atitude deveria tomar o intérprete de leis, porque a presunção iures et de iure é rara", ao comentar o artigo 251 do antigo Código de Processo Civil, que previa expressamente que a prova contra presunção legal será sempre admitida, salvo quando a própria lei a excluir.

Sobre as funções que desempenham as presunções simples ou hominis, valem as mesmas observações que fizemos sobre as presunções legais relativas, uma vez que já firmamos nosso entendimento de que aquelas se referem a uma proposição individual e concreta realizada pelo aplicador da norma, com base nas presunções relativas que se configuram como enunciados gerais e abstratos.

Delineadas as principais funções atribuídas às presunções e ficções, cabe-nos a missão de verificar a possibilidade ${ }^{108}$ de sua utilização para a instituição de obrigações tributárias.

A doutrina, de forma majoritária, rechaça o emprego das presunções absolutas e ficções para a elaboração de normas tributárias impositivas de tributos, mas a utilização das presunções relativas e simples é admissível em determinadas situações especiais.

Para o mestre PAULO AyRES BARRETO ${ }^{109}$ admitir a possibilidade de que o legislador pudesse se socorrer de ficções e presunções absolutas como hipóteses de incidência tributária, seria como admitir que nosso ordenamento não estivesse sob a regência de uma rígida

\footnotetext{
105 BARRETO, Paulo Ayres. Imposto sobre a renda e preços de transferência. São Paulo: Dialética, 2001, p. 147.

106 Ibidem, p. 147.

107 PONTES DE MIRANDA. Tratado de direito privado. 2. ed. Rio de Janeiro: Borsoi, 1954. Parte Geral, t.III, p. 446.

${ }^{108}$ Como instrumentos a serviço da praticabilidade, a utilização destes institutos será melhor aprofundada no próximo capítulo, ao sopesarmos este princípio, com os demais princípios delineados em nossa Constituição Federal.

109 BARRETO, Paulo Ayres. Imposto sobre a renda e preços de transferência. São Paulo: Dialética, 2001, p. 143. Nas suas palavras: "Propugnar a inexistência de uma rígida discriminação de competência - vale dizer, que se pudesse prever a incidência de tributo sobre o fato 'A' porque fictamente o legislador atribui a ele a condição de fato 'B', sendo a competência para instituir tributos sobre os fatos 'A' e 'B' de entes políticos distintos. Proceder nessa conformidade é fazer tabula rasa dos princípios da estrita legalidade, da tipicidade da tributação e da capacidade contributiva”.
} 
discriminação de competências e lastreado nos princípios da estrita legalidade, tipicidade da tributação e da capacidade contributiva.

Quanto à possibilidade de utilização das presunções relativas, ele as admite desde que presentes as seguintes circunstâncias: ${ }^{110}$

a) o acurado exercício do dever de fiscalização não permitiria, sem o recurso à presunção legal relativa, o efetivo controle da adoção de práticas evasivas pelo contribuinte;

b) verifique-se inequívoco nexo causal entre o fato conhecido e o desconhecido de existência provável;

c) seja facultado ao contribuinte, no curso do procedimento administrativo, anteriormente à veiculação do ato administrativo do lançamento, apresentar prova refutadora da ocorrência do fato presumido;

d) estejam as provas passíveis de evidenciar a inocorrência do fato presumido ao alcance do contribuinte por meio lícitos, em momento anterior ao da possível constituição do fato jurídico tributário.

Com base nestas mesmas circunstâncias, o mestre repudia a utilização das presunções legais mistas em qualquer hipótese, por afastar a garantia do contribuinte de apresentar qualquer que seja a prova da inocorrência do fato jurídico tributário. ${ }^{11}$

As presunções simples, no seu entender, não devem ser utilizadas para a constituição do crédito tributário, mas tão somente em "caráter sancionatório ao contribuinte que com sua desídia não cumpre os deveres instrumentais a que adstrito". ${ }^{112}$

GILBERTO DE UlhÔA CANTO"13 entende que "o legislador não pode, mediante o emprego de ficções ou presunções, expedir normas que ele não poderia formular de modo direto", isto é, se não pode instituir leis que desobedeçam às prescrições constitucionais, por óbvio que não poderá fazê-lo por ficções. Entretanto, o jurista deixa uma possibilidade de utilizá-las "sempre que a verdade legal por esse meio declarada não esteja, expressa ou implicitamente, em desacordo com a verdade legal enunciada pela norma superior”.

Para MARIA RITA FERRAGUT"114, as presunções absolutas "não podem ser validamente utilizadas para a instituição de obrigações tributárias, já que não permitem que o sujeito contra quem a presunção aproveita apresente provas cabais de que o evento descrito no fato indiciado não ocorreu". Contudo, ainda que não aprove sua utilização, por ferir a ampla defesa e o contraditório, ela entende que se as demais disposições da norma estiverem em

\footnotetext{
${ }^{110}$ BARRETO, Paulo Ayres. Imposto sobre a renda e preços de transferência. São Paulo: Dialética, 2001, p. 149-150.

${ }^{111}$ BARRETO, Paulo Ayres. Imposto sobre a renda e preços de transferência. São Paulo: Dialética, 2001, p. 150.

${ }_{112}$ BARRETO, Paulo Ayres. Imposto sobre a renda e preços de transferência. São Paulo: Dialética, 2001, p. 151.

113 CANTO, Gilberto Ulhoa. Presunções no Direito Tributário. In: Martins, Ives Gandra da Silva (Coord). Caderno de Pesquisas Tributárias: presunções no direito tributário. Vol. 9. São Paulo: Resenha Tributária, CEEU, 1984, p. 11.

${ }^{114}$ FERRAGUT, Maria Rita. Presunções no direito tributário. São Paulo: Dialética, 2001, p. 83.
} 
consonância com a Constituição, o enunciado não será reconhecido como inconstitucional e permanecerá válido no sistema como presunção legal relativa.

Da mesma forma, a professora entende que por afastar o contraditório e ampla defesa, princípios consagrados constitucionalmente, a criação de ficções jurídicas deve ser afastada para a instituição de obrigações tributárias. ${ }^{115}$

LUÍS EDUARDO SCHOUERI ${ }^{116}$ entende não haver maiores resistências para o emprego das presunções legais relativas ${ }^{117}$. Quanto às presunções absolutas, o exame de constitucionalidade não deve ser feito com base no princípio da legalidade tributária, uma vez que são decorrentes de lei, mas o limite à sua utilização deve-se ao princípio da ampla defesa no processo administrativo e judicial, mormente quando um litigante ficar impedido de comprovar a ocorrência ou não de um fato atrelado à subsunção.

No caso das ficções, consideradas por ele como mera técnica legislativa, a constitucionalidade ficará "assegurada quando a descrição da hipótese ficta se conformar - ela mesma - com o desenho constitucional do campo de competência tributária e com a definição do fato gerador na lei complementar (art. 146, III, 'a' CF)". ${ }^{118}$

LEONARDO SPERB DE PAOLA ${ }^{119}$ ressalta a importância das ficções e presunções absolutas como instrumentos técnicos no trato da elisão fiscal. Como remissões ou restrições normativas, elas equiparam, para efeitos tributários, o negócio jurídico indireto ao negócio previsto na norma tributária, aproximando a verdade econômica da verdade jurídica.

Ao dispensar "o exame da intenção elisiva do contribuinte (mas não o da equivalência econômica entre os negócios)" ${ }^{120}$, elimina-se o problema probatório. "Ao administrador, cabe, simplesmente, provar a configuração, no caso concreto, da hipótese de fato descrita na norma que traz a presunção ou ficção, sem se preocupar com a hipótese de fato da norma à qual se faz remissão". ${ }^{21}$

\footnotetext{
115 FERRAGUT, Maria Rita. Presunções no direito tributário. São Paulo: Dialética, 2001, p. 86.

${ }^{116}$ SCHOUERI, Luís Eduardo. Distribuição Disfarçada de Lucros. São Paulo: Dialética, 1996, p. 122-130.

117 As razões apontadas são: (i) ocorrência do fato gerador é constatada a partir de fatos conhecidos e comprovadamente existentes; (ii) correlação lógica entre o fato conhecido e o fato desconhecido cuja existência se quer provar; (iii) o método de interpretação e aplicação da lei a partir da presunção é previsto e autorizado em lei, e não decorre apenas de suposição do agente lançador; e (iv) a presunção não é absoluta, admitindo prova em contrário pelo contribuinte, característica implícita em todas as citadas hipóteses legais, quando não expressa. SCHOUERI, Luís Eduardo. Distribuição Disfarçada de Lucros. São Paulo: Dialética, 1996, p. 122.

118 SCHOUERI, Luís Eduardo. Distribuição Disfarçada de Lucros. São Paulo: Dialética, 1996, p. 130. Conforme adverte: "Exorbitará o legislador se a hipótese ficta estiver em desacordo com aqueles limites, ou seja, sempre que também se apontaria a inconstitucionalidade se o legislador, sem o emprego da ficção, descrevesse diretamente a hipótese ficta comofato gerador do tributo em questão".

119 PAOLA, Leonardo Sperb de. Presunções e ficções no direito tributário. Belo Horizonte: Del Rey, 1997, p. 109-112.

${ }^{120}$ Ibidem, p. 111.

${ }^{121}$ Ibidem, p. 111.
} 
As presunções relativas e as simples, na opinião do autor ${ }^{122}$, são os instrumentos mais aptos no combate à evasão fiscal por permitirem "desqualificar as falsas informações prestadas pelo contribuinte" e por auxiliarem "a encontrar, de forma aproximada, a verdadeira riqueza tributável”.

Como podemos notar, por essas exposições doutrinárias, o uso de presunções e ficções na tributação é tema controvertido, mas do qual não podemos nos esquivar, porquanto a utilização das presunções e ficções, indubitavelmente, representam as técnicas simplificadoras mais disseminadas a serviço da praticabilidade, tema que nos propusemos a enfrentar.

Conforme vimos, as presunções e ficções servem a vários propósitos: redução simplificadora da complexidade inerente do direito; combate à sonegação de impostos; sanção por desídia do contribuinte; normas relativas à matéria probatória; e finalmente, a função que mais nos interessa, como instrumentos legais a serviço da praticabilidade, que possibilitam a aplicação de uma norma tributária a milhares de casos, facilitando a mensuração da riqueza tributável sem a busca exaustiva da capacidade contributiva de cada caso individualmente considerado.

Estamos convencidos de que as presunções relativas e as simples, de acordo com a melhor doutrina, por tratarem principalmente de matéria probatória, prestam-se melhor no combate à sonegação, quando as provas são propositadamente obstaculizadas pelo contribuinte, ou ainda, como sanção pelo descumprimento dos deveres instrumentais por parte do contribuinte.

Contrariamente, as presunções absolutas e ficções permitem "moldar" a norma jurídica instituidora do tributo, atuando ora sobre a base de cálculo, possibilitando uma mensuração da riqueza com base em valores médios, típicos ou frequentes, ora sobre o sujeito passivo e na base de cálculo, como no caso da substituição tributária.

Desta forma não nos subscrevemos integralmente àqueles que entendem que as presunções absolutas e ficções devem ser afastadas peremptoriamente do nosso sistema tributário.

Conforme ressaltamos anteriormente, nosso sistema constitucional tributário foi construído com hipóteses de incidência dos tributos que não avaliam diretamente ${ }^{123}$ a renda e o

\footnotetext{
${ }^{122}$ PAOLA, Leonardo Sperb de. Presunções e ficções no direito tributário. Belo Horizonte: Del Rey, 1997, p. 111.

${ }^{123}$ Segundo Becker citando o estudo de Trotabas o sistema de avaliação direta da base de econômica de incidência (renda ou capital) é "um processo arcaico, bárbaro e frequentemente menos seguro para a descoberta da verdade e a utilização da declaração do contribuinte sujeita à comprovação é uma fórmula primitiva, para não dizer infantil”. BECKER, Alfredo Augusto. Teoria Geral do Direito Tributário. 5.ed.São Paulo: Noeses, 2010, p. 538.
} 
capital, mas sim, de forma indireta pela tributação de fatos que são considerados verdadeiros signos presuntivos de riqueza, os quais segundo BECKER ${ }^{124}$, são considerados, pela ciência jurídica, como "genuínas presunções juris et de jure e como tal comportam-se na fenomologia da incidência da regra jurídica e resultante irradiação dos efeitos jurídicos”.

Não queremos aqui consignar que o legislador é livre, a partir da utilização de presunções e ficções e com base no princípio da praticabilidade, substituir as hipóteses de incidência escolhidas pelo constituinte, por outros fatos econômicos correspondentes, que demonstrem capacidade contributiva equivalente.

O clássico exemplo de VITTORIO BERLIRI ${ }^{125}$ talha-se perfeito nesse raciocínio: o gato deveria ser considerado como um cão na aplicação do imposto sobre cães, uma vez que a posse deste gato representa uma capacidade contributiva equivalente à posse de um cão. $O$ fato econômico escolhido pelo constituinte não foi esse e tal raciocínio de equivalência é inadmissível no plano jurídico.

Também concordamos que se a construção da norma tributária fosse assim permitida, vários princípios balizadores existentes em nossa Constituição tais como: discriminação da competência impositiva; tipicidade; capacidade contributiva; entre outros, ficariam irremediavelmente comprometidos.

No mesmo exemplo do mestre italiano, supondo-se existir milhares de cães, com seus respectivos milhares de proprietários, como a administração poderia "mensurar" o valor de cada cão, individualmente, para efeito do lançamento do tributo?

É óbvio que tal investigação seria impossível ou inviável do ponto de vista prático. Nestes casos, utilizando o exemplo do mestre italiano para ilustrar, vislumbramos a possibilidade de utilização das presunções e ficções, como instrumentos técnicos a serviço da praticabilidade. O fisco poderia, por exemplo, criar uma tabela com valores médios dos cães por espécie e idade, com base no que frequentemente ocorre na compra e venda destes animais, e com esse valor de base presumida, ou fictícia, realizar o lançamento do imposto.

Nestas e em muitas situações o legislador ao se defrontar com o problema prático, utiliza-se destas padronizações ${ }^{126}$ (presunções e ficções) como solução legislativa, optando por

\footnotetext{
124 BECKER, Alfredo Augusto. Teoria Geral do Direito Tributário. 5.ed.São Paulo: Noeses, 2010, p. 539.

125 BERLIRI, Luigi Vitorio. L'Imposta di Riccheza Mobile. Milão: A. Giuffrè, 1949, p. 325.

${ }^{126}$ Segundo a doutrina: "O Poder Legislativo usa padronizações (Pauschalierungen), desconsiderando parcialmente os dados reais do caso, e dimensionando os elementos da obrigação tributária com base em valores estimados por critérios de verossimilhança (Wahrscheinlichkeitsgesichpunkten)". ÁVILA, Humberto. Teoria da Igualdade Tributária. $2^{a}$. edição. São Paulo: Malheiros, 2009, p. 84.
} 
“perder em justiça absoluta aquilo que ganhava em certeza e praticabilidade do Direito Tributário; verbi gratia: certeza e praticabilidade do lançamento tributário". ${ }^{27}$

Importante ainda ressaltar que em muitas ocasiões as ficções e as presunções, como normas remissivas são utilizadas, concedendo ao contribuinte determinadas consequências jurídicas mais benéficas de dada situação prevista em lei, à determinada hipótese ficta ou presumida. Como exemplo, podemos citar o art. $4^{\circ}$ do Decreto-Lei $n^{\circ} 288$, de 28/02/1967128, ao isentar do pagamento de tributos o envio de mercadorias à Zona Franca de Manaus, equiparando à exportação, ou ainda como no art. 3º, Parágrafo Único da lei complementar $n^{\circ} 87$ de $1996^{129}$ que equipara à exportação o envio de mercadorias ao exportador ou a outro estabelecimento da mesma empresa com fins específicos de exportação.

Mesmo nesses exemplos, as equiparações são criadas dentro da competência dos próprios entes federativos, que abrem mão da própria receita para beneficiar os contribuintes e sem interferir no equilíbrio do pacto federativo.

O que não se permite pelas equiparações é desnaturar as materialidades constitucionalmente definidas, pondo em risco a rígida competência tributária e consequentemente todo o Estado federativo.

Sobre esse tema, LUCIANO AMARO ${ }^{130}$ ensina que: “O que se veda à lei tributária é a modificação de conceitos que tenham sido utilizados por lei superior para a definição da competência tributária, se da modificação puder resultar ampliação da competência", e no final conclui que: “a) em regra, não é vedado à lei tributária modificar institutos, conceitos e formas do direito privado; b) a exceção diz respeito aos conceitos que tenham sido utilizados por lei superior para a definição da competência" ${ }^{131}$.

Em síntese, concordamos com aqueles que entendem ser vedado ao legislador, pelo uso de ficções ou presunções absolutas, equiparar outros fatos econômicos àqueles fatos jurídicos (signos presuntivos de riqueza) eleitos pelo constituinte como aspectos materiais da hipótese de incidência tributária, sob pena de menosprezo aos princípios constitucionais da rígida discriminação de competência, tipicidade e capacidade contributiva.

\footnotetext{
127 ÁVILA, Humberto. Teoria da Igualdade Tributária. 2a . edição. São Paulo: Malheiros, 2009, p. 541.

128 A exportação de mercadorias de origem nacional para consumo ou industrialização na Zona Franca de Manaus, ou reexportação para o estrangeiro, será de todos os efeitos fiscais, constantes da legislação em vigor, equivalente a uma exportação brasileira para o estrangeiro.

129 Art. $3^{\circ} \mathrm{O}$ imposto não incide sobre: [...] II - operações e prestações que destinem ao exterior mercadorias, inclusive produtos primários e produtos industrializados semi-elaborados, ou serviços;

Parágrafo único. Equipara-se às operações de que trata o inciso II a saída de mercadoria realizada com o fim específico de exportação para o exterior, destinada a:

I - empresa comercial exportadora, inclusive tradings ou outro estabelecimento da mesma empresa;

II - armazém alfandegado ou entreposto aduaneiro.

${ }^{130}$ AMARO, Luciano. Direito Tributário Brasileiro. 15a . edição. São Paulo: Saraiva, 2009, p. 101.

${ }^{131}$ Ibidem, p. 102.
} 
Por outro lado, se é vedado ao legislador desnaturar o critério material, estamos convencidos quer seja pela praticabilidade, quer seja pela menor dificuldade ${ }^{132}$, o legislador infraconstitucional muitas vezes é obrigado a abstrair a realidade e pelo uso de presunções e ficções, altera outros critérios na norma tributária, mormente no aspecto quantitativo da base de cálculo, padronizando a mensuração da riqueza tributável, sem que com isso, no mais das vezes, esteja contrariando valores constitucionalmente fixados.

\subsubsection{Presunções e ficções na estrutura da norma tributária}

As presunções e ficções, supomos ter deixado assentado, são instrumentos legislativos a serviço da praticabilidade, aos quais recorre ordinariamente o legislador, quando encontra dificuldades instransponíveis na aplicação da regra jurídica, sendo que tais abstrações podem-se hospedar ora na hipótese, ora no consequente, das normas gerais e abstratas, "produzindo seus correlatos efeitos nas normas individuais e concretas". ${ }^{133}$

Para melhor identificarmos de que forma as presunções e ficções podem se alojar na norma jurídica tributária, nos valemo-nos do instrumental fornecido pela regra-matriz de incidência tributária, que pela esquematização formal, "tem-se mostrado um utilíssimo instrumento científico, de extraordinária fertilidade e riqueza para a identificação e conhecimento aprofundado da unidade irredutível que define a fenomologia básica da imposição tributária". ${ }^{134}$

A regra-matriz de incidência tributária permite expor todos os elementos integrantes da norma: uma hipótese tributária ou antecedente, descritivo de um fato, organizada nos critérios material, espacial e temporal e um consequente ou prescritor normativo de uma relação jurídica, organizada pelos critérios pessoal e quantitativo.

O critério material da hipótese é o núcleo da descrição fática composto por um verbo sempre pessoal e de predicação incompleta e seu respectivo complemento. No critério

\footnotetext{
${ }^{132}$ Assim a doutrina: "Primeiro o legislador fixa o objetivo a atingir. Depois de fixado este objetivo ele cria o instrumento para atingir aquele objetivo visado. Este instrumento é a regra jurídica. A Ciência Jurídica mostra que a existência de ficção na embriogenia da regra jurídica é muito mais frequente do que se supõe. Muitas vezes, depois de fixado o objetivo a atingir (por ex.: arrecadação de tributos sobre o consumo ou sobre os rendimentos pagos por sociedades, o legislador verifica que é extremamente complexa ou impraticável a matéria-prima com a qual normalmente deveria cria a regra jurídica. Por exemplo: o legislador constata que, normalmente, o sujeito passivo da relação jurídica tributária do imposto de consumo deveria ser o consumidor. Todavia, isto tornaria impraticável a cobrança do imposto de consumo. Outras vezes, não há uma total impraticabilidade, porém uma maior ou menor dificuldade, como no caso da cobrança do imposto de renda sobre os rendimentos percebidos pelas pessoas físicas sócias da sociedade". BECKER, Alfredo Augusto. Teoria Geral do Direito Tributário. 5.ed.São Paulo: Noeses, 2010, p. 558-559.

${ }^{133}$ BARRETO, Paulo Ayres. Imposto sobre a renda e preços de transferência. São Paulo: Dialética, 2001, p. 142.

134 CARVALHO, Paulo de Barros. Curso de Direito Tributário. 17. ed. São Paulo: Saraiva, 2005. p. 350.
} 
espacial encontra-se o condicionante do local da ocorrência do fato e no critério espacial o condicionante de tempo, do preciso momento para ocorrência do fato.

No critério pessoal do consequente encontram-se os sujeitos ativo e passivo da relação jurídica obrigacional e, no critério quantitativo, a base de cálculo que corresponde à grandeza mensuradora de aspectos de materialidade do fato jurídico tributário e alíquota correspondente ao fator que se conjuga à base de cálculo para a determinação do valor da obrigação prestacional tributária.

Cabe a advertência de GERALDO AtALIBA de que a hipótese de incidência "é una e indivisível. Trata-se de ente lógico-jurídico unitário e incindível"135 e que "se apresenta sob vários aspectos, cuja reunião lhe dá entidade. [...] Esta multiplicidade de aspectos não prejudica, como visto, o caráter unitário e indivisível da hipótese de incidência". ${ }^{136}$

Vistos, ainda que de forma bastante sucinta e superficial, os aspectos da hipótese de incidência e do consequente, passemos a analisar de que forma as presunções e ficções podem atuar modificando-os e, considerando sua interdependência, destacar as eventuais consequências que tais alterações poderão ocasionar.

Para REgina HelenA CosTA ${ }^{137}$ esses instrumentos localizam-se com mais frequência "nos critérios material, pessoal e quantitativo da hipótese de incidência tributária".

Foge aos interesses deste estudo a discussão doutrinária sobre a localização da base de cálculo: hipótese ou no consequente. Para a autora, assim como para GERALDO ATALIBA ${ }^{138}$, ALFREDO Augusto BECKER ${ }^{139}$ e outros tantos doutrinadores, a base de cálculo encontra-se na hipótese de incidência tributária. Seguimos com PAUlo DE BARros CARVALHO ${ }^{140}$ para quem a base de cálculo está no consequente da norma, compondo juntamente com a alíquota o critério quantitativo da obrigação tributária, pelo qual é possível calcularmos o objeto da prestação.

LEONARDO SPERB DE PAOLA ${ }^{141}$ entende que, à exceção da alíquota, todos os aspectos da norma tributária podem ser objeto das presunções e ficções.

\footnotetext{
${ }^{135}$ ATALIBA, Geraldo. Hipótese de Incidência Tributária. 6a . edição. São Paulo: Malheiros, 2005, p. 65.

${ }^{136}$ Ibidem, p. 76. O mestre Ataliba critica ainda a utilização da expressão elementos da hipótese de incidência por alguns autores por entender que: "esta expressão sugere a ideia de que se está diante de algo que entra na composição doutra coisa e serve para formá-la. Cada aspecto da hipótese de incidência não é algo a se stante, de forma que associado aos demais resulte na composição da hipótese de incidência, mas, são simples qualidades, atributos ou relações de uma coisa uma e indivisível, que é a hipótese de incidência, juridicamente considerada. Sob esta perspectiva, a h.i., é um todo unitário e incindível".

${ }^{137}$ COSTA, Regina Helena. Praticabilidade e justiça tributária - Exequibilidade de Lei Tributária e Direitos do Contribuinte, São Paulo: Malheiros, 2007, p. 158.

${ }^{138}$ ATALIBA, Geraldo. Hipótese de Incidência Tributária. 6a . edição. São Paulo: Malheiros, 2005, p. 78.

${ }^{139}$ BECKER, Alfredo Augusto. Teoria Geral do Direito Tributário. 5.ed.São Paulo: Noeses, 2010, p. 351. Para o autor: "Nas regras jurídicas de tributação, o núcleo da hipótese de incidência é sempre a base de cálculo".

${ }^{140}$ CARVALHO, Paulo de Barros. Fundamentos Jurídicos da Incidência Tributária. 8. ed.. São Paulo: Saraiva, 2010, p. 242.

${ }^{141}$ PAOLA, Leonardo Sperb de. Presunções e ficções no direito tributário. Belo Horizonte: Del Rey, 1997, p. 120.
} 
No nosso entender, repisamos, o aspecto material não pode ser objeto de modificação por presunção ou ficção.

Admitir ser possível ao legislador infraconstitucional alterar ou modificar o aspecto material, o núcleo fático da norma tributária, por presunções ou ficções, seria admitir que toda justiça tributária erigida sobre a capacidade contributiva pudesse ficar irremediavelmente comprometida.

$\mathrm{O}$ aspecto material é o fato juridicamente relevante escolhido pelo constituinte para apreender uma riqueza a ser tributada. A escolha deste signo presuntivo de riqueza baseou-se em uma presunção absoluta, que não admite contestação e que somente é admitida na instituição dos tributos pelas normas gerais e abstratas constitucionais.

Como ilustração, vamos supor uma pessoa que tenha como renda familiar um salário mínimo, mas por sorte, acabe ganhando em um sorteio de final de ano um carro importado de valor altíssimo. Na virada do ano, no dia 01 de janeiro, o "ser proprietário de veículo automotor" previsto no art. 155, III, da Constituição Federal, incidirá por força do lançamento e, nosso sortudo ganhador do prêmio, estará colocado como sujeito passivo do IPVA, devendo recolher aos cofres públicos estaduais o valor do tributo devido, embora não tenha a capacidade contributiva "presumida" por ser proprietário do veículo.

Neste exemplo, fica claro que embora ele não tenha a riqueza relacionada com a propriedade do veículo, não poderá contestar a capacidade contributiva presumida (presunção iures et iure) constitucionalmente na escolha destes signos. ${ }^{142}$

Assim como as presunções absolutas, as ficções também não podem modificar o aspecto material da norma de incidência tributária. Ambas as categorias jurídicas, entendemos, são normas remissivas que permitem ampliar a esfera de abrangência de um tributo a outras situações, muitas vezes em razão da imprecisão da linguagem do legislador.

Assim quando, por exemplo, a lei ${ }^{143}$ equipara a pessoa física a contribuinte, quando aquela importa bens do exterior, para efeito de tributação do ICMS, opera a ficção que por razões valorativas do direito, ampliou a realização de operação de circulação de mercadorias aspecto material da hipótese de incidência do ICMS - para essa situação que ordinariamente

\footnotetext{
${ }^{142}$ Assim a doutrina: "As valorizações dos interesses em conflito e o critério de preferência que inspiraram a solução legislativa (regra jurídica criada para solucionar aquele conflito) participam da objetividade desta solução (regra jurídica) e não podem ser reexaminados pelo intérprete sob o pretexto de uma melhor adequeção à realidade histórica posterior (ao caso concreto que realizou a hipótese de incidência daquela regra jurídica)". BECKER, Alfredo Augusto. Teoria Geral do Direito Tributário. 5.ed.São Paulo: Noeses, 2010, p. 74.

${ }^{143}$ Artigo $7^{\circ}$ da lei $n^{\circ} 6374 / 89$ - Contribuinte do imposto é qualquer pessoa, natural ou jurídica, que de modo habitual ou em volume que caracterize intuito comercial, realize operações relativas à circulação de mercadorias ou preste serviços de transporte interestadual ou intermunicipal ou de comunicação.

Parágrafo único - É também contribuinte a pessoa natural ou jurídica que, mesmo sem habitualidade ou intuito comercial:

1 - importe mercadoria ou bem do exterior, qualquer que seja a sua finalidade.
} 
não seria tributada. Insistimos, entretanto, que não houve qualquer modificação no aspecto material, qual seja a operação de circulação de mercadorias.

No aspecto temporal, as ficções e presunções são amplamente utilizadas quando ocorrem dificuldades na determinação do preciso momento da ocorrência do fato tributário, como no caso ficção do período anual no imposto sobre a renda. ${ }^{144}$

Sobre esta dificuldade, PAUlo DE BARros CARVALHO ${ }^{145}$ doutrina que a eleição do critério temporal da hipótese - "conjunto de elementos que nos habilitam a identificar a condição que atua sobre determinado evento, subordinando-o no tempo" - é realizada no plano das elaborações legislativas e, com base neste conceito, parte da doutrina passou a distinguir os fatos geradores em: instantâneos, continuados e complexivos.

Os fatos geradores instantâneos, como nos casos do ICMS e IPI, verificam-se e esgotam-se em um determinada fração de tempo, dando origem em cada ocorrência a uma obrigação tributária autônoma.

Os fatos continuados, como o IPTU e ITR, abrangeriam as situações duradouras que se repetiriam em intervalos maiores ou menores de tempo e, por fim, os complexivos, consubstanciados no exemplo clássico do IR, como aqueles em que o processo de formação ocorre em um fluxo contínuo de tempo, mas somente no momento definido pela legislação é que nasce a relação jurídica tributária.

Concordamos integralmente com a crítica formulada pelo mestre paulista sobre o descabimento em se falar de fatos geradores complexivos. Mesmo que composto por inúmeros outros fatores que se entrelacem, o fato gerador somente ocorrerá no determinado momento legalmente estipulado. "Antes dele, nada de jurídico existe, em ordem ao nascimento da obrigação tributária. Só naquele átimo irromperá o vínculo jurídico que, pelo fenômeno da imputação normativa, o legislador associou ao acontecimento do suposto". ${ }^{146}$

Resta claro que no caso de determinadas materialidades, como no caso da percepção de renda, que ocorre continuamente, o legislador deve-se servir de presunções ou ficções para definir o exato momento em que ela esteja definitivamente constituída, sob pena de inviabilizar a tributação.

\footnotetext{
${ }^{144}$ PEREZ DE AYALA, Jose Luis; GONZALEZ, Eusebio. Curso de Derecho Tributario. Tomo I. 6a. ed. Madri: Editoriales de Derecho Reunidas, 1991, p. 75.

${ }^{145}$ CARVALHO, Paulo de Barros. Curso de Direito Tributário. 17. ed. São Paulo: Saraiva, 2005. p. 268-273.

${ }^{146}$ CARVALHO, Paulo de Barros. Curso de Direito Tributário. 17. ed. São Paulo: Saraiva, 2005. p. 271. "Se o chamado fato gerador complexivo aflora no mundo jurídico, propagando seus efeitos, apenas em determinado instante, é por força convir em que, anteriormente àquele momento, não há que falar-se em obrigação tributação, pois nenhum fato ocorreu na conformidade do modelo normativo, inexistindo portanto os efeitos jurídico-fiscais próprios da espécie".
} 
Outro exemplo de ficção no aspecto temporal ocorre quando o legislador reputa ocorrido o serviço de transporte interestadual no momento em que se inicia e não no momento de sua conclusão. A dificuldade superada pelo legislador com essa ficção foi a de permitir ao estado de origem, a quem cabe o ICMS desta prestação de serviço, controlar e fiscalizar o recolhimento do tributo, o que não seria possível se o fato gerador só ocorresse no final do serviço em outra unidade da federação.

Outra ficção no ICMS ${ }^{147}$ é considerar as mercadorias que estão no estoque no momento de encerramento do estabelecimento, como se vendidas fossem, em obediência ao princípio da não cumulatividade, vez que o crédito destas mercadorias já foi considerado.

No ITCMD - Imposto sobre Transmissão Causa Mortis e Doação de quaisquer bens ou direitos - o critério material é fixado no momento da transmissão causa mortis e da doação ${ }^{148}$. Neste tributo o legislador utilizou-se do instituto da morte presumida, para viabilizar a incidência do imposto de transmissão a partir do momento da abertura da sucessão provisória, conforme disposição dos arts. $6^{\circ}$ e $7^{\circ}$ do Código Civil de $2002^{149}$, com a ressalva de que no caso de aparecimento do ausente fica assegurada a restituição do imposto recolhido.

A utilização da presunção da morte do ausente, alterando o critério temporal do ITCMD, com base em probabilidade, conforme estipulada pelo direito civil, já foi autorizada pelo STF na súmula no ${ }^{\circ}$ 331: “É legítima a incidência do imposto de transmissão causa mortis no inventário por morte presumida".

No aspecto espacial, a ficção muito citada na doutrina é do princípio da territorialidade, permitindo a um Estado tributar rendas auferidas em outros países. ${ }^{150}$

\footnotetext{
${ }^{147}$ Artigo $3^{\circ}$ da lei $n^{\circ}$. 6374/89: Para os efeitos desta lei, considera-se: I - saída do estabelecimento, a mercadoria constante do estoque na data do encerramento de suas atividades; [...].

${ }^{148}$ Artigo $2^{\circ}$ da lei $\mathrm{n}^{\circ}$. 10705/00 - O imposto incide sobre a transmissão de qualquer bem ou direito havido:

I - por sucessão legítima ou testamentária, inclusive a sucessão provisória;

II - por doação.

$\S 1^{\circ}$ - Nas transmissões referidas neste artigo, ocorrem tantos fatos geradores distintos quantos forem os herdeiros, legatários ou donatários.

$\S 2^{\circ}$ - Compreende-se no inciso I deste artigo a transmissão de bem ou direito por qualquer título sucessório, inclusive o fideicomisso.

$\S 3^{\circ}$ - A legítima dos herdeiros, ainda que gravada, e a doação com encargo sujeitam-se ao imposto como se não o fossem. $\S 4^{\circ}$ - No caso de aparecimento do ausente, fica assegurada a restituição do imposto recolhido pela sucessão provisória.

$\S 5^{\circ}$ - Estão compreendidos na incidência do imposto os bens que, na divisão de patrimônio comum, na partilha ou adjudicação, forem atribuídos a um dos cônjuges, a um dos conviventes, ou a qualquer herdeiro, acima da respectiva meação ou quinhão.

${ }^{149}$ Lei 10.406 de 2002. Art. 6o A existência da pessoa natural termina com a morte; presume-se esta, quanto aos ausentes, nos casos em que a lei autoriza a abertura de sucessão definitiva.

Art. 7o Pode ser declarada a morte presumida, sem decretação de ausência:

I - se for extremamente provável a morte de quem estava em perigo de vida;

II - se alguém, desaparecido em campanha ou feito prisioneiro, não for encontrado até dois anos após o término da guerra.

Parágrafo único. A declaração da morte presumida, nesses casos, somente poderá ser requerida depois de esgotadas as buscas e averiguações, devendo a sentença fixar a data provável do falecimento.

150 Neste sentido ao tratar da imprescindibilidade de elementos de conexão para avaliação da capacidade contributiva na tributação extraterritorial: "o Princípio da Territorialidade encontra suporte, também, na própria ideia de capacidade contributiva. Justificação para a escolha daqueles eventos que darão nascimento à obrigação tributária, a capacidade contributiva foi acolhida, nos mais diversos ordenamentos jurídicos, de modo tácito ou expresso, como critério para a
} 
Outro exemplo ainda no critério espacial, muito debatido nos tribunais administrativos e judiciários, ocorre pela ficção que estabelece como local da operação para tributação pelo ICMS ${ }^{151}$ o da situação do estabelecimento onde ocorra a entrada física da mercadoria ou bem importados do exterior. Assim, mercadoria importada por contribuinte paulista, que foi desembarcada e desembaraçada no porto do Espírito Santo, deverá ter o ICMS calculado sobre a importação, recolhido para o estado de São Paulo.

No aspecto pessoal ou subjetivo do consequente, as presunções e ficções atuam mais intensamente na alteração do sujeito passivo, como ocorre na lei do IPI ${ }^{152}$ que equipara estabelecimentos atacadistas, a estabelecimento industrial quando adquirir produtos importados. ${ }^{153}$

Ainda como exemplo de alteração no aspecto subjetivo podemos citar a chamada substituição tributária para frente, instituída pela Emenda Constitucional no 3, de 17 de março de 1993, assim prevista na Constituição Federal:

$\mathrm{CF} / 88$. Art. $150, \S 7^{\circ}$. A lei poderá atribuir a sujeito passivo da obrigação tributária a condição de responsável pelo pagamento de imposto ou contribuição, cujo fato gerador deva ocorrer posteriormente, assegurada a imediata e preferencial restituição da quantia paga, caso não se realize o fato gerador presumido.

concretização do Princípio da Igualdade. A adoção de tal Princípio, por sua vez, impõe que o contribuinte esteja perante o Estado, em uma situação suscetível de avaliação econômica. Daí a resistência aparecer como uma ficção jurídica, já que o elemento pessoal aponta a existência de relações econômicas no âmbito do Estado, seja o gozo de bens, seja a sua participação em atos ou fatos de conteúdo econômico". SCHOUERI, Luís Eduardo. Direito Tributário. São Paulo: Saraiva, 2011, p. 678.

${ }^{151}$ Artigo 23 da lei n. 6374/89 - O local da operação ou da prestação, para efeito de cobrança do imposto e definição do responsável, é:

I - tratando-se de mercadoria ou bem:

[...]

f) o da situação do estabelecimento onde ocorra a entrada física da mercadoria ou bem, importados do exterior e desembaraçados.

${ }^{152}$ Art. $7^{\circ}$ da lei 7798/89. Equiparam-se a estabelecimento industrial os estabelecimentos atacadistas que adquirirem os produtos relacionados no Anexo III, de estabelecimentos industriais ou dos seguintes estabelecimentos equiparados a industrial:

I - estabelecimentos importadores de produtos de procedência estrangeira;

II - filiais e demais estabelecimentos que exerçam o comércio de produtos importados ou industrializados por outro estabelecimento da mesma firma;

III - estabelecimentos comerciais de produtos cuja industrialização haja sido realizada por outro estabelecimento da mesma firma ou de terceiros, mediante a remessa, por eles efetuadas, de matérias-primas, produtos intermediários, embalagens, recipientes, moldes, matrizes ou modelos; e

IV - estabelecimentos comerciais de produtos do capítulo 22 da TIPI, cuja industrialização tenha sido encomendada a estabelecimento industrial, sob marca ou nome de fantasia de propriedade do encomendante, de terceiro ou do próprio executor da encomenda.

[...]

${ }^{153}$ Para Florence Haret esta "regra presuntiva que equipara industrial a atacadistas e adquirentes de produtos importados é clara e ilegitimamente ampliativa da esfera de competência federal. [...] apesar das semelhanças de segunda ordem, por trabalharem industrial, atacadista e adquirente de produtos importados com produtos industrializados, são atividades essencialamente distintas, diversas nas suas qualidades primárias, não podendo ser objeto de equiparação, pela via presuntiva, uma a outra. Tal formulação normativa, por assumir como critério de semelhança características secundárias, nada mais é do que uma ficção tributária, instituto este usado pelo legislador para fins de constituir outras hipóteses exonerativas". HARET, Florence. Teoria e Prática das Presunções no Direito Tributário. São Paulo: Noeses, 2011, p. 677. 
A substituição tributária para frente ${ }^{154}$ além de alterar o aspecto subjetivo, inserindo a figura do substituto como responsável pelo pagamento do imposto, modifica também o aspecto temporal, antecipando a ocorrência do fato gerador do ICMS e o aspecto quantitativo, ao substituir o valor real da venda por um valor fixado arbitrariamente pela administração.

Deixamos por fim, a análise da alteração do aspecto quantitativo, em particular a base de cálculo, pelas presunções e ficções, por ser este o expediente mais utilizado pelo legislador, como instrumental de simplificação a serviço da praticabilidade na aplicação em massa de determinados tributos.

A base de cálculo para ALFREDO BECKER ${ }^{155}$ é o único elemento que revela o gênero do tributo, pois para o autor "não interessa saber quais os elementos que compõem o pressuposto material ou quais as suas decorrências necessárias, nem importa encontrar o mais importante daqueles elementos ou decorrências", ou seja, "basta verificar a base de cálculo: a natureza desta conferirá, sempre e necessariamente, o gênero jurídico do tributo".

Em sua concepção, a importância da base de cálculo é tal que além de estar na hipótese de incidência, é o seu núcleo, que confere o gênero jurídico ao tributo. ${ }^{156}$

Com este posicionamento concorda Geraldo AtAliBa ao apontar que "a base imponível é ínsita à hipótese de incidência" ${ }^{157}$. Como aspecto da hipótese de incidência ele a conceitua como "uma perspectiva dimensível do aspecto material da h.i. que a lei qualifica com a finalidade de fixar critério para a determinação, em cada obrigação tributária concreta, do quantum debetur”. ${ }^{158}$

O mestre ATALIBA assevera ser impossível não se desnaturar um tributo ao se utilizar de uma grandeza na base de cálculo “que não seja ínsita na materialidade de sua hipótese de incidência"159, mas também chama atenção para o fato de ser a base de cálculo um conceito legal, o que traz como consequência: (i) poder abranger todas as perspectivas dimensíveis do fato jurídico da hipótese de incidência, ou somente algumas; e (ii) poder atribuir configuração jurídica própria às perspectivas dimensíveis do fato, de forma distinta das existentes no mundo fenomênico. ${ }^{160}$

\footnotetext{
${ }^{154}$ A substituição tributária será abordada em maior profundidade no capítulo relativo aos estudos de casos.

155 BECKER, Alfredo Augusto. Teoria Geral do Direito Tributário. 5.ed.São Paulo: Noeses, 2010, p. 396-397.

${ }^{156}$ Em suas palavras: "A hipótese de incidência da regra jurídica de tributação tem como núcleo: a base de cálculo; como elementos adjetivos: todo os demais elementos que integram sua composição. Resumindo, o espectro atômico da hipótese de incidência da regra jurídica de tributação revela que em sua composição existe um núcleo e um, ou mais, elementos adjetivos. O núcleo é a base de cálculo e confere o gênero jurídico ao tributo". BECKER, Alfredo Augusto. Teoria Geral do Direito Tributário. 5.ed.São Paulo: Noeses, 2010, p. 398.

${ }^{157}$ ATALIBA, Geraldo. Hipótese de Incidência Tributária. 6ª edição. São Paulo: Malheiros, 2005, p. 108.

${ }^{158}$ ATALIBA, Geraldo. Hipótese de Incidência Tributária. 6a . edição. São Paulo: Malheiros, 2005, p. 108.

${ }^{159}$ ATALIBA, Geraldo. Hipótese de Incidência Tributária. 6ª edição. São Paulo: Malheiros, 2005, p. 111.

${ }^{160}$ ATALIBA, Geraldo. Hipótese de Incidência Tributária. 6a . edição. São Paulo: Malheiros, 2005, p. 110-111.
} 
Essa conclusão a que chegou o mestre, parece-nos ser de vital importância neste estudo. A definição legal da base de cálculo deve indiscutivelmente manter uma coerência com a definição legal da hipótese de incidência, ou seja, não se pode tributar, v.g., o patrimônio com base na renda do contribuinte, mas poderá o legislador estipular como base de cálculo do patrimônio um valor médio de mercado, atribuindo-lhe uma perspectiva dimensível do fato jurídico, distinta da realidade do mundo social.

AIRES F. BARRETO"161 ao desenvolver o raciocínio de que "sendo a hipótese de incidência tributária a descrição hipotética de um fato, a base de cálculo, como atributo seu, só poderá ter, igualmente, caráter normativo, tão hipotético quanto a própria hipótese de incidência em que se contém", conclui que "se o todo é hipotético, igual natureza terão os atributos respectivos".

A mensuração do fato jurídico a ser tributado será opção do legislador de acordo com as respectivas peculiaridades, mas esse arsenal de opções está limitado na Constituição, porquanto a definição legal do critério genérico a ser utilizado deverá estar em consonância com o arquétipo previamente previsto constitucionalmente.

Nesta linha, na análise da padronização da base de cálculo do IPTU pelas plantas genéricas de valor, o jurista afirma que "nada impede se obtenha o valor venal pela adoção de Mapas de Valores Genéricos, na medida em que estes nada mais representam do que a utilização de um critério objetivo para a apuração do valor venal dos imóveis". ${ }^{162}$

PAULO DE BARROS CARVALHO, embora discorde desses autores por entender que a base de cálculo está consequente da norma tributária e não no antecedente ${ }^{163}$, também entende que a análise do binômio hipótese de incidência e base de cálculo é imprescindível para a compreensão da estrutura da tipologia tributária ${ }^{164}$.

Esse binômio, por ele denominado princípio de dualidade compositiva, constituise em verdadeira "diretriz constitucional, firmada no momento em que o legislador realizava o delicado trabalho de montar a rígida discriminação de competências tributárias, preocupado em preservar os princípios da Federação e da autonomia dos Municípios”. ${ }^{165}$

O professor paulista ressalta a importância da base de cálculo ao ensinar que:

\footnotetext{
${ }^{161}$ BARRETO, Aires Fernandino. Curso de Direito Tributário Municipal. São Paulo: Saraiva, 2009, p. 155.

162 Ibidem, p. 158.

${ }^{163}$ Também nos filiamos a esse entendimento.

${ }^{164}$ Nas suas palavras: "Em conclusão, no direito brasileiro o tipo tributário encontra-se integrado pelo relacionamento lógico e harmônico da hipótese de incidência e da base de cálculo. O binônimo, adequadamente reconhecido, revela a natureza do tributo submetido à investigação, permitindo a análise de sua compatibilidade relativamente ao sistema constitucional, sem interferência das imprecisões tão frequentes no discurso legislativo". CARVALHO, Paulo de Barros. Direito Tributário Linguagem e Método. 3. ed. São Paulo: Noeses, 2009, p. 399.

${ }^{165}$ CARVALHO, Paulo de Barros. Direito Tributário Linguagem e Método. 3. ed. São Paulo: Noeses, 2009, p. 398.
} 
Partindo de tais considerações, concluo serem três as funções da base cálculo: a) função mensuradora, por competir-lhe medir as proporções reais do fato; b) função objetiva, em virtude de compor a específica determinação do débito; e c) função comparativa, por confirmar, infirmar ou afirmar o correto elemento material do antecedente normativo. ${ }^{166}$

Pela função comparativa, conclui, a base cálculo deve sempre prevalecer na determinação da natureza jurídica do tributo, devendo inclusive prevalecer sobre a hipótese de incidência quando houver descompasso entre elas.

Quanto à função mensuradora que permite a apuração da real riqueza contida no fato tributário, PEREZ DE AYALA ${ }^{167}$ faz a assertiva de que as ficções em direito conduzem a uma desconformidade entre a base de cálculo e a riqueza efetivamente existente, por valorizarem o fato imponível com elementos que não se enquadram naqueles exigidos pelo princípio da capacidade contributiva.

Tanto as ficções como as presunções sobre a base de cálculo estão sobejamente difundidas em nosso direito tributário.

A razão, acreditamos, reside na dificuldade encontrada pelo fisco para mensurar e fazer prova da real riqueza encontrada no fato jurídico, o que nos tributos a serem lançados para milhares de contribuintes em situações particulares as mais diversas possíveis, resultaria na impraticabilidade da tributação.

O exemplo do IPTU é bastante didático para mostrar que sem a utilização do Mapa Genérico de Valores, criando um critério objetivo de base de cálculo para a exação do tributo, as dificuldades encontradas para sua apuração seriam intransponíveis.

O mesmo se dá com o IPVA, que sem a tabela genérica de valores dos automóveis, como base de cálculo presumida, teria uma apuração praticamente impossível.

No imposto sobre a renda, o cálculo da base de cálculo é o resultado aritmético entre soma das receitas tributáveis com a subtração de determinadas despesas dedutíveis. Com a finalidade de facilitar a comprovação de parte dessas despesas tanto para as pessoas físicas como para as pessoas jurídicas e, mesmo para o fisco, num eventual lançamento de ofício, a legislação tributária lança mão de simplificações como: declaração simplificada para a pessoa física na qual se presumem despesas dedutíveis de $20 \%$ do valor dos rendimentos; e o lucro presumido para determinado grupo de pessoas jurídicas, com o qual não se tributa toda a receita auferida pelo contribuinte, mas apenas um determinado percentual fixo, não se permitindo qualquer tipo de dedução.

${ }^{166}$ CARVALHO, Paulo de Barros. Direito Tributário Linguagem e Método. 3. ed. São Paulo: Noeses, 2009, p. 399.

${ }^{167}$ PÉREZ DE AYALA, José Luis. Las ficciones en el derecho tributário. Madrid: Editorial de Derecho Financiero, 1970, p. 101. 
Simplificações semelhantes também são utilizadas no ICMS. A apuração mensal do imposto a ser recolhido no final de cada mês é obtida pelo resultado aritmético da soma de todos os débitos referentes às saídas, subtraindo da soma de todos os créditos relativos à aquisição de matérias primas e insumos. Em alguns segmentos a dificuldade pelo número excessivo de aquisições levou o fisco a criar a presunção denominada crédito outorgado, com o qual o contribuinte faz jus a um determinado percentual da soma de todas as suas saídas, como crédito, sem qualquer tipo de comprovação.

Outro exemplo citado pela doutrina é da disciplina dos preços de transferência ${ }^{168}$. Segundo PAUlo Ayres BARRETO, esse regramento visa evitar "a transferência indireta (por intermédio dos preços pactuados) de lucros para o exterior, nas operações realizadas por pessoas vinculadas"169. Uma vez constatada essa transferência indireta "promove-se o ajuste na base calculada do imposto sobre a renda, no âmbito da relação jurídica intersubjetiva, instalada no consequente da regra-matriz de incidência desse imposto". ${ }^{170}$

As pautas de valores, fixadas geralmente por decretos ou portarias, constituem mais um exemplo de substituição da base de cálculo por um valor médio presumido a ser adotado no lançamento de determinado tributo, dependendo da mercadoria que se está operacionalizando.

A pauta fiscal ainda pode ser adotada nas operações sujeitas à substituição tributária. Nestas operações, como o valor a ser praticado na venda ao consumidor final (que presumidamente ocorrerá) é desconhecido no momento da operação entre substituto e substituído (por exemplo: fabricante e comerciante), a legislação ${ }^{171}$ prevê a utilização de pautas fiscais como valores de referência a serem adotados, ou ainda, como "uma prévia unidade de valor das operações futuras". ${ }^{172}$

\subsection{Padronização, Tipificação ou Regimes Objetivos}

\footnotetext{
${ }^{168}$ Os preços de transferência são aqui citados apenas como exemplo de presunções que atingem o critério quantitativo, mas pelo seu intuito antievasivo não será abordado em maior profundidade neste estudo.

${ }_{169}$ BARRETO, Paulo Ayres. Imposto sobre a renda e preços de transferência. São Paulo: Dialética, 2001, p. 112.

170 Ibidem, p.112.

${ }^{171}$ RICMS/00. Artigo 41 - Na falta de preço final a consumidor, único ou máximo, autorizado ou fixado por autoridade competente, a base de cálculo do imposto para fins de substituição tributária com retenção antecipada do imposto será o preço praticado pelo sujeito passivo, incluídos os valores correspondentes a frete, carreto, seguro, impostos e outros encargos transferíveis ao adquirente, acrescido do valor resultante da aplicação de percentual de margem de valor agregado estabelecido conforme disposto pela legislação em cada caso.

172 ÁVILA, Humberto. Imposto sobre a circulação de mercadorias: ICMS; substituição tributária; base de cálculo; pauta fiscal; preço máximo ao consumidor; diferença constante entre o preço usualmente praticado e o preço constante da pauta ou o preço máximo ao consumidor sugerido pelo fabricante; exame de constitucionalidade. Revista Dialética de Direito Tributário, n.123. São Paulo: Dialética, 2005, p. 123.
} 
Como afirmamos anteriormente a alteração da base de cálculo por abstrações generalizantes é o expediente mais utilizado pela administração, quando a serviço da praticabilidade precisa simplificar o lançamento de determinados tributos para uma pluralidade de situações concretas, sob pena de inviabilizar a tributação.

MiSABEL DERZI denomina “padronização" ou "modo de pensar padronizante" essa técnica que propicia "a aplicação em massa, através da substituição do caso isolado concreto, por um esquema ou padrão". 173

Segundo doutrina "as pautas de valores, autorizadas ou não pela lei, são utilíssimas para a simplificação da execução, além de necessárias à uniformidade na aplicação do Direito" 174 . Tratam-se de "presunções gerais, comuns a grupos que possibilitam a aplicação massificante da norma, com desprezo das diferenças individuais relevantes do ponto de vista legal" 175 .

Humberto Ávila, com supedâneo na doutrina alemã, denomina tipificação (Typisierung) "o fenômeno, por meio do qual alguns elementos da realidade são escolhidos em detrimento de outros [...] Tipificação, nessa acepção, é avaliação limitada da realidade; é avaliação defeituosa da situação de fato" ${ }^{176}$.

A professora MiSABEL DERZI assevera que a doutrina alemã denomina esse modo de pensar padronizante, como modo de pensar impropriamente chamado tipificante.

Foi denominado tipificante por criar tipos com referência a um padrão médio, resultado das características comuns, médias, frequentes, que substituem as peculiaridades inerentes a cada caso concreto, funcionando como uma presunção. ${ }^{177}$

Sua crítica ao utilizar "impropriamente" refere-se ao fato de que esses tipos não são os verdadeiros tipos jurídicos por ela adotados “como ordens abertas, graduáveis, transitivas, de características renunciáveis". ${ }^{178}$

No seu entender esses tipos criados na padronização constituem-se em "rígidos padrões, esquemas fixos, em regra numericamente definidos, não raro funcionando como

\footnotetext{
173 DERZI, Misabel de Abreu Machado. Direito tributário, direito penal e tipo, 2. ed. São Paulo: Revista dos Tribunais, 2008 , p .332 .

174 Ibidem, p. 334.

175 DeRZI, Misabel de Abreu Machado. Direito tributário, direito penal e tipo, 2. ed. São Paulo: Revista dos Tribunais, 2008, p .334.

176 ÁVILA, Humberto. Teoria da Igualdade Tributária. 2a . edição. São Paulo: Malheiros, 2009, p. 83. O autor classifica a tipificação em material e formal: "No caso de tipificação material ou categórica, a aplicação opera com uma ficção de uma situação de fato não concretizada, independente de prova em contrário. Ocorrida a situação tida como típica, deve ser dada a consequência. Na hipótese de tipificação formal ou hipotética, a aplicação trabalha com dados de fato, cuja ocorrência ou nãoocorrência pode ser demonstrada". Ibidem, p. 83.

${ }^{177}$ Ibidem, p. 336.

${ }^{178}$ Ibidem, p. 336.
} 
presunções iuris et de iure" ${ }^{179}$. E conclui: “Ora, o objetivo da padronização simplificadora é exatamente evitar a aplicação individual do Direito (que o tipo, no sentido próprio do termo, propicia), estabelecendo, através da uniformidade rígida e fixa, a aplicação da lei a milhares de casos". ${ }^{180}$

Encontramos ainda na doutrina ${ }^{181}$ os chamados regimes de estimação objetiva, indiciários ou forfait ${ }^{182}$, como outras denominações para as padronizações, sempre com a proposta de fixar métodos alternativos para medir a base imponível.

Como nestes regimes são utilizados os traços comuns e universais de um contribuinte médio para a formulação de uma base imponível, adotou-se a qualificação de objetivo em contraposição ao subjetivo, o qual implica observar todas as características individuais de cada caso concreto. ${ }^{183}$

A busca desses regimes de estimação objetiva, assim como apontado pela doutrina nacional para as padronizações, é garantir a praticabilidade das normas tributárias, principalmente na aplicação maciça de determinados tributos. Assim a doutrina ${ }^{184}$ :

La necessidade de tomar em cuenta a ese contribuyente <<médio〉> para hacer efectiva una generalidade que busque la claridade estructural y las sistematicidade, es especialmente importante en los tributos massivos, em los cuales la imposición sobre la renta ocupa um lugar destacado. Y respecto a los cuales resulta transcendental garantir la practibilidad de las normas tributarias.

Com supedâneo na doutrina alemã, CASALTA NABAIS ${ }^{185}$ denomina a padronização como tipificação, tipi(ci)zação, esquematização ou estandardização, constituindo-se em uma técnica a que se socorre o legislador para reduzir ou atenuar a complexidade fiscal.

Com a tipificação a lei é criada apenas abranger os casos típicos, abstraindo-se os casos anormais ou raros, de forma a desonerar a administração "da espinhosa e dispendiosa, quando não mesmo impossível missão de averiguação exaustiva e de apuramento total e integral

\footnotetext{
${ }^{179}$ DeRZI, Misabel de Abreu Machado. Direito tributário, direito penal e tipo, 2. ed. São Paulo: Revista dos Tribunais, 2008 , p. 336.

${ }^{180}$ Ibidem, p. 336

${ }^{181}$ NOVOA, César Garcia. Los métodos de simplificatión fiscal em la experiência latino americana. Referencia comparativa a los casos brasileno y argentino. Revista de Contabilidad y Tributación del Centro de Estudios Financieros, n. 59. Madri, outubro/2003, p. 70. Segundo ele: "Estos regímenes consisten en la definición de unas <<normas materiales〉> alternativas a las que configurem el régimen de estimación directa, orientadas a cuantificar el hecho imponible com critérios diferentes a los que fundamentam su 《< medición directa 〉, al tempo que, por médio de los mismos, se flexibiliza la obligación de llevanza de contabilidade por empresários y profesionales".

${ }^{182}$ Expressão francesa significando a convenção ou acordo pelo qual uma das partes do contrato se obriga a fazer ou a fornecer alguma coisa por um preço certo, perdendo ou ganhando com a estipulação. MALTA, Christovão Piragibe Tostes; LEFÈVRE, Julia Brotero. Dicionário Jurídico. Edições Trabalhistas. $5^{a}$ ed. 1987, p. 406.

${ }^{183}$ NOVOA, César Garcia. Los métodos de simplificatión fiscal em la experiência latino americana. Referencia comparativa a los casos brasileno y argentino. Revista de Contabilidad y Tributación del Centro de Estudios Financieros, n. 59. Madri, outubro/2003, p. 75.

${ }^{184}$ Ibidem, p. 75.

${ }^{185}$ NABAIS, José Casalta. O Dever Fundamental de Pagar Imposto - Contributo para a compreensão constitucional do estado fiscal contemporâneo. 3. ed. Coimbra: Almedina, 2012, p. 622.
} 
dos múltiplos e complexos factos tributários e dos aspectos em que os mesmos se desdobram, bem como da resolução das difíceis questões colocadas pela interpretação do caso limite". ${ }^{186}$

Segundo o mestre CASALTA NABAIS ${ }^{187}$ existem duas formas ou modalidades de tipificação: (i) quantitativa na qual os tipos (Häuftigskeitstypus) são criados com base na ideia de frequência ou média; e (ii) qualitativa na qual os tipos (Gestaltungstypus) são criados com base em particularidades, ou especificidades hábeis a distinguirem de outras situações.

No fenômeno de massificação, que nos interessa mais incisivamente, NABAIS ${ }^{188}$ salienta que tipificação quantitativa tem maior expressividade, "a qual consubstanciando-se em quantificações, globalizações ou regimes forfaitaires (Pauschalierungen), conduz nomeadamente, ao estabelecimento de rendimentos, matérias colectáveis ou impostos mínimos, ou à fixação de deduções e abatimentos máximos expressos em percentagens ou em montantes numericamente definidos (standard dedutions)".

Podemos concluir que a padronização, tipificação, fórmulas de estimação objetiva ou outras denominações utilizadas pela doutrina e jurisprudência para se referir à técnica que, em nome da praticabilidade, presume uma base de cálculo fixada em uma normalidade média, abstraindo-se os casos atípicos ou anormais, é imprescindível na tributação em massa ao: garantir uma arrecadação eficiente; um imposto exequível e praticável; e coerência no sistema fiscal.

Nossa próxima missão é determinar quais os limites que essa objetividade em prol do princípio da praticabilidade poderão ser empregados pela administração, quando confrontada com os demais princípios constitucionais, tanto naqueles que encerram valores quanto naqueles que estabelecem limites objetivos para garantir a harmonia de nosso ordenamento.

\footnotetext{
${ }^{186}$ NABAIS, José Casalta. O Dever Fundamental de Pagar Imposto - Contributo para a compreensão constitucional do estado fiscal contemporâneo. 3. ed. Coimbra: Almedina, 2012, p. 622.

${ }^{187}$ Ibidem, p. 622 e 623

${ }^{188}$ NABAIS, José Casalta. O Dever Fundamental de Pagar Imposto - Contributo para a compreensão constitucional do estado fiscal contemporâneo. 3. ed. Coimbra: Almedina, 2012, p. 623.
} 


\section{A Praticabilidade em face dos Princípios Constitucionais Tributários}

O direito é uno e indecomponível e em razão desta unicidade, o estudo de qualquer norma, inclusive as tributárias, perde sentido e completude se não observadas as relações de coordenação e hierarquização dentro do sistema em que se encontram.

A noção fundamental de sistema implica a existência de "um conjunto de elementos relacionados entre si e aglutinados perante uma referência determinada". ${ }^{1}$

LOURIVAL VILANOVA entende que "falamos de sistema onde encontrem elementos e relações e uma forma dentro de cujo âmbito, elementos e relações se verifiquem [...] Sistema implica ordem, isto é, uma ordenação das partes constituintes, relações entre as partes ou elementos". ${ }^{2}$

É na Constituição Federal que encontramos o fundamento de validade da trama de todas as normas de coordenação e subordinação, base de sustentação da ordem jurídica brasileira como um sistema de normas.

$\mathrm{Na}$ Constituição encontramos as normas regulando os poderes do Estado, principalmente no campo da tributação, bem como as normas assecuratórias das garantias e liberdades individuais dos cidadãos perante aqueles poderes. Essas normas são, segundo PAULO DE BARROS CARVALHO, "verdadeiros princípios, tal o poder aglutinante de que são portadoras, permeando, penetrando e influenciando um número inominável de outras regras que lhe são subordinadas". ${ }^{3}$

O poder da administração, principalmente na instituição de tributos, é amplamente regulado por diversos princípios constitucionais genéricos, que se irradiam por toda a ordem jurídica e os princípios constitucionais tributários, que visam limitar o poder fazendário no campo específico dos tributos.

Se é na Carta Maior que encontramos esses princípios organizadores do ordenamento jurídico, nosso estudo pede necessariamente uma incursão no texto constitucional para analisarmos até que ponto a praticabilidade se harmoniza e se submete a esses mandamentos.

\footnotetext{
${ }^{1}$ CARVALHO, Paulo de Barros. Curso de Direito Tributário. 17. ed. São Paulo: Saraiva, 2005. p. 132.

${ }^{2}$ VILANOVA, Lourival. As estruturas lógicas e o sistema do direito positivo. 3. ed. São Paulo: Noeses, 2005, p. 162.

${ }^{3}$ CARVALHO, Paulo de Barros. Curso de Direito Tributário. 17. ed. São Paulo: Saraiva, 2005. p. 143.
} 
A praticabilidade, conforme já assumimos anteriormente ${ }^{4}$, constitui-se também em um princípio, de tal sorte que na análise de casos concretos, quando ocorre conflito de interesses, comportará temperamentos ${ }^{5}$ na decisão, conferindo alto grau de subjetividade ao aplicador, que irá ponderar razões que no seu entender privilegiarão alguns princípios em detrimentos de outros.

Das lições de DwORKIN ${ }^{6}$ extrai-se que no caso de conflitos entre princípios, o princípio a ser adotado será aquele que diante do caso concreto apresente uma dimensão de peso (dimension of weight), e represente a melhor razão para a solução do impasse, mas sua eleição não invalida os outros princípios que apontem para direções contrárias.

A praticabilidade poderá justificar tantas facilidades quantas queira a administração, sem pretender, entretanto, sobrepor-se às exigências constitucionais maiores, atinentes ao consentimento, legalidade, tipicidade, ampla defesa etc. ${ }^{7}$

Evidenciando a importância do princípio da praticabilidade na esfera tributária no combate à evasão, melhoria nos sistemas de arrecadação e no processo de redução de complexidade das normas tributárias, PAULO AYRES BARRETO ${ }^{8}$ deixa registrado sua preocupação com a seguinte questão: “Como compaginar, a um só tempo, em matéria tributária, presunções absolutas, ficções, princípio da praticabilidade, de um lado, e estrita legalidade, tipicidade, rígida discriminação constitucional de competência impositiva, de outro".

A atividade administrativa com base em signos indiciários, sem os devidos limites, dando ensejo a excessos de discricionariedade, é também motivo de inquietação de PAULO DE BARROS CARVALHO; no seu entender, tais comportamentos dos agentes administrativos, muitas vezes arbitrários, trazem sérios prejuízos à racionalidade e ao bom funcionamento do sistema tributário. Eis aqui sua advertência9:

No entanto, independentemente de se tratar de presunção absoluta ou de ficções, é fundamental, em todas essas situações recorrentes em direito tributário, identificar a correta adequação destes institutos ao princípios fundamentais da ampla defesa, da impugnabilidade dos atos administrativos do fisco, da reserva legal, da capacidade contributiva e da progressividade, como formas de garantir os valores constitucionalmente defendidos na Carta Magna.

\footnotetext{
${ }^{4}$ Vide item 3.3.

${ }^{5}$ Paulo Ayres Barreto distinguindo as regras dos princípios, entende que aquelas servem justamente como opção do legislador para fixar os temperamentos que a aplicação dos princípios comporta: "Do cotejo entre a significação dos princípios e das regras que definem e circunscrevem de forma mais precisa o mecanismo de realização desses princípios, exsurgirá, como resultante, a efetiva diç̧ão constitucional”. BARRETO, Paulo Ayres. Contribuições: regime jurídico, destinação e controle. São Paulo: Noeses, 2006. p. 21.

${ }^{6}$ DWORKIN, Ronald. Taking Rights Seriously. London: Duckwoth, 1991, p. 39-43.

${ }^{7}$ GONÇALVES, José Artur Lima. Imposto sobre a renda. Pressupostos constitucionais. São Paulo: Malheiros, 1997, p. 163.

${ }^{8}$ BARRETO, Paulo Ayres. Imposto sobre a renda e preços de transferência. São Paulo: Dialética, 2001, p. 140.

${ }^{9}$ CARVALHO, Paulo de Barros. Direito Tributário Linguagem e Método. 3. ed. São Paulo: Noeses, 2009, p. 927-928.
} 
As normas simplificadoras editadas em prol da praticabilidade, isto é, com o intuito de viabilizar a execução das leis pela administração, devem estar submetidas aos princípios de caráter geral que se irradiam por todo o sistema jurídico tais como: segurança jurídica, igualdade, legalidade, justiça, entre outros, bem como aos princípios específicos do direito tributário como capacidade contributiva, tipicidade, estrita legalidade etc.

Passemos à análise destes princípios fundamentais para desvendar, as limitações impostas pelo ordenamento, tanto ao legislador como ao aplicador no trato das normas de simplificação.

\subsection{Segurança Jurídica}

A tributação, dentro da concepção moderna de Estado, "constitui autêntico poderdever, cujo exercício traduz-se no emprego de instrumentos que lhe possibilitem a obtenção dos recursos necessários ao desempenho de suas atividades". ${ }^{10}$

O tributo é a principal fonte de recursos para o Estado cumprir suas finalidades: prestação de serviços públicos e manutenção do patrimônio coletivo.

Como a administração não pode prescindir de exigir de seus administrados o tributo, surge um ponto de extrema tensão: de um lado a autoridade do Poder Público e de outro a liberdade individual.

A tensão nestas relações jurídicas aparece sobretudo porque "a esse direito estatal, consubstanciado na supressão de parcela do patrimônio dos sujeitos, para a sustentação das necessidades coletivas, consoante um regime vinculante, corresponde, evidentemente, um dever, por parte daqueles, de satisfazer tal obrigação, em prol da sociedade". ${ }^{11}$

Como o Estado pode atingir o direito de propriedade do particular, e por consequência sua liberdade, há a necessidade, em respeito ao primado da segurança jurídica, de normas de proteção ao contribuinte.

Podemos afirmar, então, que o direito tributário pode ser visto "como o conjunto de normas jurídicas que disciplinam a instituição, a arrecadação e a fiscalização dos tributos"12, mas, principalmente, como um conjunto de regras a dar segurança ao Administrado,

\footnotetext{
${ }^{10}$ COSTA, Regina Helena. Curso de Direito Tributário. São Paulo: Saraiva, 2009. p.3.

${ }^{11}$ COSTA, Regina Helena. Curso de Direito Tributário. São Paulo: Saraiva, 2009, p. 4.

12 Ibidem, p. 10.
} 
para não ser surpreendido por uma tributação que lhe subtraia parcela do patrimônio ou sua liberdade.

SOUTO MAIOR BORGES ensina que a segurança jurídica pode ser vista tanto como um valor transcendente ao ordenamento jurídico que inspira as normas que lhe atribuem efetividade, tratando-se, portanto, de matéria a ser estudada pela Filosofia do Direito, ou como valor, princípio da segurança jurídico-tributária, consignado em normas de direito positivo, postulando para sua efetividade de valores preservadores dela própria na criação e aplicação do tributo, tais como: irretroatividade; legalidade; isonomia; efetividade da jurisdição tributária, administrativa ou judicial. "Tudo isso junto e muito mais que isso". ${ }^{13}$

PAUlO DE BARRos CARVALHO ${ }^{14}$, em suas lições sobre o primado da segurança jurídica, denomina-o verdadeiro sobreprincípio, que se encontra na implicitude ${ }^{15}$ dos textos de direito posto, efetivando-se pela atuação da certeza juntamente com outros princípios, como o da legalidade, da anterioridade, da igualdade, da irretroatividade, da universalidade da jurisdição etc.

Por entender que o princípio da segurança jurídica engloba todos os valores que operaram por realizar qualquer que seja a ordem jurídico-normativa, o professor assevera que no campo do direito tributário, "praticamente todos os países do mundo ocidental, ao reconhecerem aqueles vetores que se articulam axiologicamente, proclamam, na sua implicitude, essa diretriz suprema". ${ }^{16}$

Na relação fisco e contribuinte, o princípio da segurança jurídica será encontrado em "um feixe de estimativas, integradas para garantir o desempenho da atividade jurídicotributária pelo Estado-administração". ${ }^{17}$

O entendimento de Geraldo ATALIBA ${ }^{18}$ é também no sentido de que a segurança jurídica é da essência do próprio direito, atuando como verdadeiro instrumento assecuratório dos recíprocos direitos e deveres, nas relações entre governantes e governados. "Quanto mais segura uma sociedade, tanto mais civilizada. Seguras então as pessoas que têm certeza de que

\footnotetext{
${ }^{13}$ BORGES, Souto Maior. Princípio da Segurança Jurídica na Criação e Aplicação do Tributo. Revista de Direito Tributário, n. 63. São Paulo: Malheiros, 1993, p. 206.

${ }^{14}$ CARVALHO, Paulo de Barros. Direito Tributário Linguagem e Método. 3. ed. São Paulo: Noeses, 2009, p. 271-272.

${ }^{15}$ Sobre a implicitude deste princípio, o mestre aponta que "a circunstância de figuraram no texto, ou no contexto, não modifica o teor de prescritividade da estimativa, que funciona como vetor valorativo que penetra as demais regras do sistema, impregnando-lhes, fortemente, a dimensão semântica. Por isso mesmo são colocados no altiplano da Constituição. De lá, precisamente onde começam todos os processos de positivação das normas jurídicas, descem aqueles primados para os vários escalões da ordem legislada, até atingir as regras terminais do sistema, timbrando os preceitos que ferem diretamente as condutas em interferência intersubjetiva, com a força axiológica dos mandamentos constitucionalmente consagrados". CARVALHO, Paulo de Barros. Direito Tributário Linguagem e Método. 3. ed. São Paulo: Noeses, 2009, p. 271-272.

${ }^{16}$ CARVALHO, Paulo de Barros. Direito Tributário Linguagem e Método. 3. ed. São Paulo: Noeses, 2009, p. 271.

${ }^{17}$ CARVALHO, Paulo de Barros. Direito Tributário Linguagem e Método. 3. ed. São Paulo: Noeses, 2009, p. 271-272.

${ }^{18}$ ATALIBA, Geraldo. República e Constituição. 2a . ed., São Paulo: Malheiros, 2004, p. 184.
} 
o Direito é o objetivamente um e que os comportamentos do Estado ou dos demais cidadãos não discreparão".

A segurança jurídica ao mesmo tempo em que assegura aos cidadãos os direitos e garantias contra arbítrios da administração na tributação, também garante ao fisco o direito de tributar sempre que realizado o fato tributário previsto no ordenamento. "O estatuto tributário é não só do contribuinte. É do fisco e contribuinte numa relação isonômica. Ao fisco o que é do fisco, mas só o que é dele. Ao contribuinte somente o que lhe pertence". ${ }^{19}$

Para MisABEl DERZI as ideias de "anterioridade, previsibilidade, irretroatividade, jurisdição, processo devido e especialidade (impropriamente denominada tipicidade) são conceitos por meio dos quais se manifesta um dos fins objetivados no Estado de Direito: a segurança jurídica". ${ }^{20}$ Relacionando a concepção de Estado de Direito, com a democracia e contenção do arbítrio, conclui que "a segurança jurídica fica, então, hipertrofiada e a lei parece o caminho mais idôneo para alcançá-la". ${ }^{21}$

A certeza do direito, que com outros mandamentos constitucionais, opera para concretizar o primado da segurança jurídica, exige que a conduta esteja detalhadamente especificada $^{22}$, bem como requer previsibilidade, muitas vezes denominada "princípio da nãosurpresa" ao possibilitar ao contribuinte saber com antecedência tudo que lhe será imposto, dando-lhe oportunidade de tomar as decisões que julgar mais adequadas em face das consequências impostas pela legislação.

Relacionando a ideia de certeza, elemento primordial na obtenção da segurança, com a previsibilidade, Tercio SAMPAIO FERRAZ JR. ${ }^{23}$ enfatiza que "por certeza entende-se a determinação permanente dos efeitos que o ordenamento jurídico atribui a um dado comportamento, de modo que o cidadão saiba ou possa saber de antemão a consequência das suas próprias ações".

A certeza exige por um lado que as normas jurídicas sejam gerais e abstratas, evitando-se deixar ao aplicador a regulação de todas as situações concretas que nelas se

\footnotetext{
${ }^{19}$ BORGES, Souto Maior. Princípio da Segurança Jurídica na Criação e Aplicação do Tributo. Revista de Direito Tributário, n. 63. São Paulo: Malheiros, 1993, p. 209.

${ }^{20}$ DERZI, Misabel de Abreu Machado. Direito tributário, direito penal e tipo, 2. ed. São Paulo: Revista dos Tribunais, 2008, p.122.

${ }^{21}$ Ibidem, p. 121.

22 "alguém, estando obrigado, tendo a permissão ou estando proibido, deve saber, especificamente, qual a conduta que lhe foi imputada, comportamento esse que não se compadece com a dúvida, com a inexatidão, com a incerteza”. CARVALHO, Paulo de Barros. Direito Tributário Linguagem e Método. 3. ed. São Paulo: Noeses, 2009, p. 271-272.

${ }^{23}$ FERRAZ JR, Tércio Sampaio. Segurança Jurídica e Normas Gerais Tributárias. Revista de Direito Tributário, n. 17/18, ano

5. São Paulo: Revista dos Tribunais, 1981, p. 51.
} 
incluem, e que essas normas devem valer para todos igualmente, isto é, a norma deve obedecer ao princípio da igualdade. ${ }^{24}$

Ao discorrer sobre os objetivos do sistema tributário, SCHOUERI $^{25}$ afirma que a previsibilidade não pode ser prescindida, pois "permite que os contribuintes possam tomar suas decisões com maior acerto, visto que conhecerão os ônus envolvidos. Nesse sentido, a previsibilidade é instrumento de eficiência".

A certeza jurídica pode também ser compreendida, no plano jurídico, como "a expectativa de direitos que o sistema cria em seus jurisdicionados para fins de instaurar a estabilidade e eficácia de suas ordens e de sua estrutura" ${ }^{26}$. Surgem, assim, inseridas na ideia da certeza a confiança "pelo destinatário do dizer verdadeiro do enunciador" 27 e a crença da veracidade de seu discurso.

Interligando de forma inseparável a segurança jurídica com a certeza, ALBERTO $\mathrm{XAVIER}^{28}$ enuncia o princípio da confiança na lei fiscal, segundo o qual: "as leis tributárias devem ser elaboradas de tal modo que garantam ao cidadão a confiança de que lhe facultam um quadro completo de quais as suas ações ou condutas originadoras de encargos fiscais".

CASAlta NABAIS ${ }^{29}$ revela que a ideia de proteção da confiança, ínsita ao estado democrático de direito, é um dos aspectos mais relevantes da segurança jurídica na perspectiva dos direitos do indivíduo, "segundo a qual estes devem poder confiar em que tanto à sua actuação como à actuação das entidades públicas incidente sobre os seus direitos, posições e relações jurídicas, adaptada em conformidade com normas jurídicas vigentes, se liguem efeitos jurídicos duradouros, previstos ou calculados com base nessas mesmas normas".

Para que haja essa proteção é pressuposto a segurança jurídica do direito objetivo, tanto na estabilidade das normas jurídicas de não serem arbitrariamente modificadas (segurança jurídica ex post), como na previsibilidade (segurança jurídica ex ante) dos efeitos jurídicos por parte dos cidadãos. ${ }^{30}$

Como é cediço, nos dias de hoje no Brasil, essa confiança nas leis fiscais está seriamente comprometida, em razão do número exacerbado de normas expedidas e por sua falta de precisão. O contribuinte, no maioria das vezes, encontra-se desamparado e inseguro, uma

\footnotetext{
${ }^{24}$ FERRAZ JR, Tércio Sampaio. Segurança Jurídica e Normas Gerais Tributárias. Revista de Direito Tributário, n. 17/18, ano 5. São Paulo: Revista dos Tribunais, 1981, p. 51.

${ }^{25}$ SCHOUERI, Luís Eduardo. Direito Tributário. São Paulo: Saraiva, 2011, p. 45.

${ }^{26}$ HARET, Florence. Teoria e Prática das Presunções no Direito Tributário. São Paulo: Noeses, 2011, p. 569.

${ }^{27}$ Ibidem, p. 569.

${ }^{28}$ XAVIER, Alberto. Os Princípios da Legalidade e da Tipicidade da Tributação. 1ª ed. São Paulo: RT, 1978, p. 46.

${ }^{29}$ CABAIS, José Casalta. O Dever Fundamental de Pagar Impostos - Contributo para a compreensão constitucional do estado fiscal contemporâneo. 3. ed. Coimbra: Almedina, 2012, p. 395.

${ }^{30}$ CABAIS, José Casalta. O Dever Fundamental de Pagar Impostos - Contributo para a compreensão constitucional do estado fiscal contemporâneo. 3. ed. Coimbra: Almedina, 2012, p. 395.
} 
vez que essa profusão de leis impede qualquer planejamento racional das atividades econômicas, permanecendo sempre ameaçado de ser surpreendido pela instituição de um novo tributo inconstitucional ou de difícil apreensão.

Oportuna as palavras do erudito tributarista BRANDÃO MACHADO ${ }^{31}$ sobre esse tema:

A falta de convicção do legislador brasileiro, em matéria de tributos, traduzida ora na edição de normas imprecisas e abundantes, ora na criação de regras ilegítimas, põe em risco a segurança do contribuinte, que pode, no arranjo de seus negócios, ser surpreendido com a exigência de tributo descabido ou não claramente definido em lei.

A insegurança jurídica que vivemos, não passou despercebida por PAULO DE BARROS CARVALHO ${ }^{32}$ :

\begin{abstract}
Vivemos momento crítico, caracterizado pela instabilidade das instituições, principalmente no que concerne ao quadro jurídico-tributário que vigora no Brasil. $\mathrm{O}$ país passa por intervalo difícil de sua história e toda a desordem a que assistimos no plano econômico irradia-se para o setor político, social (em sentido estrito), moral e, como não poderia deixar de ser, para os domínios do direito. Certamente que nunca atravessamos período de tanta turbulência na edição de regras atinentes às condutas inter-humanas, de modo especial, no exercício das pretensões impositivas do Estado enquanto Poder Tributante. A ausência de expectativas estáveis impede qualquer iniciativa de planejamento racional por parte dos sujeitos passivos (...).
\end{abstract}

Segundo a doutrina atual, o princípio da segurança jurídica deve ser visto como um dos pilares do estado de direito. De fato, é de se esperar que um Estado que se autodenomina Estado Democrático de Direito coíba ao máximo toda forma de arbítrio estatal, de forma que as condutas estatais possam ser previsíveis e perfeitamente identificáveis as suas consequências.

A concepção de uma sociedade juridicamente organizada requer como premissa o reconhecimento da segurança jurídica como um valor supremo, que se traduz na ideia de previsibilidade, regularidade e estabilidade das relações jurídicas, sobretudo quando se está a considerar as relações jurídicas de natureza pública, onde há participação direta do Estado no exercício de sua potestade administrativa.

\title{
5.1.1 Segurança Jurídica e Praticabilidade
}

A impossibilidade de aferição da efetiva base de cálculo pela administração impende em nome da praticabilidade, a utilização de normas simplificadoras, presumindo-se uma base de cálculo alternativa.

\footnotetext{
${ }^{31}$ MACHADO, Brandão. ISS e o Arrendamento Mercantil. Revista Dialética de Direito Tributário, n. 141, pp. 46-55.

${ }^{32}$ CARVALHO, Paulo de Barros. Direito Tributário Linguagem e Método. 3. ed. São Paulo: Noeses, 2009, p. 661.
} 
Tal expediente, por outro lado, ao valorizar uma riqueza próxima, mas não a real, contribui para a incerteza da relação jurídica, o que nos permite concluir que "no âmbito da certeza, as presunções apresentam-se, portanto, com esse caráter dúbio: afirmando e negando, num só tempo, a certeza do direito". ${ }^{33}$

Surge, com essa questão, um conflito entre o princípio da segurança jurídica e o princípio da praticabilidade: implicando por um lado garantir a certeza e com isso a segurança jurídica dos direitos fundamentais dos administrados; e por outro lado garantir à administração instrumentos hábeis para tornar viável a tributação e consequentemente a imprescindível arrecadação de recursos.

FERREIRO LAPATZA ${ }^{34}$ enfatiza que não há conflito entre estes princípios, uma vez que como é impraticável ao direito prescrever normas para a infinidade de situações específicas, a praticabilidade que postula a edição de normas mais simples e, na medida do possível mais estáveis, garante aos cidadãos, sem grandes esforços, a previsibilidade das consequências fiscais de seus atos, reforçando, por conseguinte, a segurança jurídica.

Muito elucidativa a ponderação de PAUlo DE BARRos CARVAlHo sobre esse delicado problema: “[...] entendo ser certo, que o uso de valorações presuntivas pela lei se justifica, pois trata de introduzir certeza ali onde a medição direta da base real implica sérias dificuldades, aumentando a pressão fiscal indireta sobre o contribuinte. Por outro lado, a determinação da base mediante as presunções absolutas ou ficções trazem consigo nota positiva de neutralidade". ${ }^{35}$

A posição de MARIA Rita FERRAGUT também discorda “do entendimento de que as presunções ferem a segurança jurídica" 36 e que poderão ser utilizadas "nas hipóteses de

\footnotetext{
${ }^{33}$ HARET, Florence. Teoria e Prática das Presunções no Direito Tributário. São Paulo: Noeses, 2011, p. 571. Segundo a autora: "No âmbito das presunções, se de um lado ela traz certeza ali onde não há, instituindo limites objetivos ao aplicador do direito, que não pode presumir senão com base (e fundamentalmente de validade) naquilo prescrito pela regra presuntiva, de outro, é ela mesma mecanismo que traz incertezas, pois partindo da premissa de que o ato/fato é possível, enuncia elementos descritivos de outros atos que lhe são próximos mas que não são representativos do ato/fato propriamente dito".

${ }^{34}$ No original: "Principio que postula normas claras y sencillas y, en la medida de lo posible, estables, de tal forma que los ciudadanos puedan, sin grandes esfuerzos, medir las consecuencias fiscales de sus actuaciones. De tal forma que Administración y administrados puedan sin grandes esfuerzos ni elevados costes aplicar unos tributos cuyas normas respondan a la elemental idea de que el Derecho no puede reflejar em sus normas las mil diferentes circunstancias em que um hecho puede presentarse em la realidade, sino los hechos típicos, normales, desprovidos de las notas accidentales que acompañan em la realidade a cada uno de ellos, que dibujan com frecuencia los trazos más característicos de uma determinada vida social". Lapatza, Ferreiro. El principio de legalidade y la reserva de ley. Revista de Direito Tributário

${ }^{35}$ CARVALHO, Paulo de Barros. Direito Tributário Linguagem e Método. 3. ed. São Paulo: Noeses, 2009, p. 927. O professor faz a seguinte ressalva: "No entanto, independentemente de se tratar de presunção absoluta ou de ficções, é fundamental, em todas essas situações a correta adequação destes institutos aos princípios fundamentais da ampla defesa, da impugnabilidade do atos administrativos do fisco, da reserva legal, da capacidade contributiva e da progressividade, como formas de garantir os valores constitucionalmente defendidos na Carta Magna".

${ }^{36}$ FERRAGUT, Maria Rita. Presunções no direito tributário. São Paulo: Dialética, 2001, p. 91.
} 
impossibilidade de comprovação direta do evento descrito no fato, já que seu principal fim é o de suprir deficiências probatórias". ${ }^{37}$

Concordamos com essa posição e ponderando ambos os valores envolvidos, podemos concluir que em determinadas situações, nas quais a medição efetiva da riqueza tornase inviável do ponto de vista prático, a utilização de abstrações na base de cálculo deve ser permitida, desde que outros valores constitucionalmente garantidos sejam preservados.

Assim, embora a praticabilidade se mostre apta a reforçar a certeza e previsibilidade, os outros limites demarcados pelo primado da segurança jurídica, mormente no que tange à anterioridade, irretroatividade, efetividade da jurisdição tributária, administrativa ou judicial entre outros, não poderão ser ultrapassados ou ameaçados, sob pena de ferir constitucionalmente os direitos e garantias individuais e a estabilidade das relações normativas.

${ }^{37}$ FERRAGUT, Maria Rita. Presunções no direito tributário. São Paulo: Dialética, 2001, p. 91. 


\subsection{Legalidade}

O princípio da legalidade surge como corolário das ideias de certeza e previsibilidade, pilares do primado da segurança jurídica, como exposto no item anterior.

Mandamento expressamente consagrado no art. $5^{\circ}$., II, da Constituição prescrevendo que "ninguém será obrigado a fazer ou deixar de fazer alguma coisa senão em virtude de lei”, espraia-se como diretriz geral por todo ordenamento, repercutindo no campo tributário pelo art. 150, I, da Carta Magna, que veda “à União, aos Estados, ao Distrito Federal e aos Municípios: I - exigir ou aumentar tributo sem lei que o estabeleça" e no art. 97 do CTN ${ }^{38}$, que enumera o rol das matérias reservadas privativamente à disciplina legal.

A legalidade pode ser estudada tanto no sentido formal como no sentido material. No primeiro caso, consoante nos ensina MiSABEL DERZI: "somente a lei, formalmente compreendida, vale dizer, como ato oriundo do Poder Legislativo, é ato normativo próprio à criação dos fatos jurígenos, deveres e sanções tributárias", ou seja, no sentido formal verificase se $a$ lei foi enunciada por autoridade competente e pelo procedimento competente, ambos previstos no ordenamento.

A legalidade no aspecto material impõe que tanto o antecedente como o consequente, com todos os critérios da norma jurídica tributária estejam determinados em lei. ${ }^{39}$ O princípio da legalidade, no seu aspecto material, é também tratado como princípio da estrita legalidade, ou ainda como princípio da tipicidade tributária, por só considerar típico o fato e todos os seus elementos que se ajustarem precisamente àqueles descritos na lei.

\footnotetext{
${ }^{38}$ CTN. "Art. 97. Somente a lei pode estabelecer:

I - a instituição de tributos, ou a sua extinção;

II - a majoração de tributos, ou sua redução, ressalvado o disposto nos artigos 21, 26, 39, 57 e 65;

III - a definição do fato gerador da obrigação tributária principal, ressalvado o disposto no inciso I do $\S 3^{\circ}$ do artigo 52, e do seu sujeito passivo;

IV - a fixação de alíquota do tributo e da sua base de cálculo, ressalvado o disposto nos artigos 21, 26, 39, 57 e 65 ;

V - a cominação de penalidades para as ações ou omissões contrárias a seus dispositivos, ou para outras infrações nela definidas;

VI - as hipóteses de exclusão, suspensão e extinção de créditos tributários, ou de dispensa ou redução de penalidades.

$\S 1^{\circ}$ Equipara-se à majoração do tributo a modificação da sua base de cálculo, que importe em torná-lo mais oneroso.

$\S 2^{\circ}$ Não constitui majoração de tributo, para os fins do disposto no inciso II deste artigo, a atualização do valor monetário da respectiva base de cálculo".

${ }^{39}$ Assim a doutrina: "Pela diretriz da estrita legalidade, não podem ser utilizados outros enunciados, senão aqueles introduzidos por lei. Seja a menção genérica do acontecimento factual, com seus critérios compositivos (material, espacial e temporal), seja a regulação da conduta, firmada no consequente, também com seus critérios próprios, vale dizer, indicação dos sujeitos ativo e passivo (critério pessoal), bem como da base de cálculo e da alíquota (critério quantitativo), tudo há de vir expresso em enunciados legais. CARVALHO, Paulo de Barros. Direito Tributário Linguagem e Método. 3. ed. São Paulo: Noeses, 2009. p. 294.
} 
Para MisABel DeRZI ${ }^{40}$, a denominação tipicidade, como princípio da legalidade materialmente considerado, é imprópria. Tipos, como doutrina, são ordens flexíveis, socialmente abertas e são utilizados, no sentido não técnico, pelo direito penal e direito tributário, onde o legislador quer reforçar a segurança jurídica por uma legalidade material absoluta, como conceitos fechados, determinados e especificante.

Para PAUlo De BARRos CARVALHO ${ }^{41}$ o princípio da tipicidade tributária deve ser visto em duas dimensões:

(i) no plano legislativo, como a estrita necessidade de que a lei adventícia traga no seu bojo, de modo expresso e inequívoco, os elementos descritores do fato jurídico e os dados prescritores da relação obrigacional; e (ii) no plano da facticidade, como exigência da estrita subsunção do evento aos preceitos estabelecidos na regra tributária que o prevê, vinculando-se, obviamente, à adequada correspondência estabelecida entre a obrigação que adveio do fato protocolar e a previsão genérica constante da norma abstrata, conhecida como "regra-matriz de incidência".

Ainda que a legalidade contribua de modo decisivo para a segurança jurídica dos cidadãos, na medida em que garante que somente deverão ser obrigados a praticar ações prescritas por seus representantes democraticamente eleitos, há limitações em nosso ordenamento para esse princípio, vale dizer, a lei não pode tratar de qualquer matéria.

Sobre essa limitação, José SOUTO MAIOR BORGES assevera que "o princípio da legalidade é formal e material" "42, uma vez que apenas o aspecto formal não garantiria que determinadas matérias poderiam ser estabelecidas com ampla, alguma ou nenhuma generalidade por lei, acabando por concluir que ${ }^{43}$ :

[...] a lei, no direito positivo brasileiro, é ato normativo de caráter geral e abstrato, numa decorrência da tripartição constitucional os Poderes. Como são distintas e inconfundíveis entre si as funções do Legislativo, Executivo e Judiciário, a lei não pode conter, mascarado, um provimento de caráter individual e concreto, porque essa é a seara dos atos administrativos e das sentenças judiciais.

ROQUE CARRAZZA também enxerga no princípio da tripartição dos poderes uma limitação ao princípio da legalidade, afirmando que a interpretação do art. $2^{\circ}$., com os arts. 44 a 75, 76 a 91 e 92 a 126, todos da Constituição "exigem que só o legislador produza normas

\footnotetext{
40 “Usam a expressão tipo no sentido não técnico e designam por tipicidade o princípio segundo o qual a norma deve descrever os delitos e os tributos, descendo a especificações que permitam ao intérprete e aplicador da lei determinar com precisão os fatos jurígenos e suas consequências. A lei, não se deve valer de conceitos indeterminados, amplamente abstratos ou ambíguos mas utilizar conceitos determinados especificantes". DERZI, Misabel de Abreu Machado. Direito tributário, direito penal e tipo, 2. ed. São Paulo: Revista dos Tribunais, 2008, p. 126.

${ }^{41}$ CARVALHO, Paulo de Barros. Direito Tributário Linguagem e Método. 3. ed. São Paulo: Noeses, 200, p. 298.

42 BORGES, José Souto Maior. Princípio constitucional da legalidade e as categorias obrigacionais. Revista de Direito Tributário, n. 23-24. São Paulo: Revista dos Tribunais, 1983, p. 86-87.

${ }^{43}$ Ibidem, p. 86-87.
} 
genéricas e abstratas, em oposição às individuais e concretas, que são os atos administrativos e as sentenças, de competência, respectivamente, dos Poderes Executivo e Judiciário". ${ }^{44}$

Podemos sintetizar as distintas funções que a legalidade cumpre em matéria tributária: (i) formal pela exigência da lei como indispensável veículo introdutor; (ii) material ao exigir a descrição pormenorizada da hipótese de incidência, sujeito ativo e passivo, base de cálculo e alíquota; e (iii) vinculante dos órgãos administrativos à lei. ${ }^{45}$

\subsubsection{Legalidade e Praticabilidade}

Será possível em razão desta tipicidade cerrada, que o princípio da estrita legalidade impõe, coadunar as abstrações necessárias, que em nome da praticabilidade tornam exequíveis as leis tributárias?

ROQUE CARRAZZA de forma contundente adverte que o propósito de aumentar a arrecadação ou punir infratores não pode prevalecer sobre a segurança jurídica dos contribuintes, razão pela qual os tipos tributários não podem ser alargados e os agentes físcais não podem se converter em legisladores, criando novos tipos além dos previstos na lei. "Em suma, os princípios da tipicidade fechada e da estrita legalidade impedem a tributação ou a condenação do contribuinte por presunções, ficções ou indícios. Muito menos por razões de conveniência social ou atendendo aos anseios da opinião pública". ${ }^{46}$

Embora não nos subscrevamos integralmente ao entendimento do autor, concordamos que eventuais manobras da administração não poderão modificar o tipo tributário em momento posterior à edição da lei instituidora do tributo, com o simples intuito de aumentar a arrecadação.

De fato, conforme acreditamos ter deixado demonstrado, não podemos considerar como simples "manobras" arrecadatórias a utilização de eventuais presunções ou ficções como forma de tornar praticável a arrecadação e fiscalização do tributo.

CASALTA NABAIS ${ }^{47}$ alega que eventuais incompatibilidades entre as exigências da lei e a realidade da administração justificam uma competência de emergência ou de

\footnotetext{
${ }^{44}$ CARRAZZA, Roque Antonio. Curso de Direito Constitucional Tributário. 22. ed. São Paulo: Malheiros, 2006, p. 349-350. ${ }^{45}$ COSTA, Regina Helena. Praticabilidade e justiça tributária - Exequibilidade de Lei Tributária e Direitos do Contribuinte, São Paulo: Malheiros, 2007, p. 142.

${ }^{46}$ CARRAZZA, Roque Antonio. Curso de Direito Constitucional Tributário. 22. ed. São Paulo: Malheiros, 2006, p. 259.

${ }^{47}$ NABAIS, José Casalta. O Dever Fundamental de Pagar Imposto - Contributo para a compreensão constitucional do estado fiscal contemporâneo. 3. ed. Coimbra: Almedina, 2012, p. 377.
} 
necessidade, enfim uma ilegalidade necessária (LUHMANN) capaz de aliviar uma apuração dos fatos tributários considerando-se todo o potencial de diferenciação e individualização.

Esse alegado estado de necessidade administrativo impede a avaliação individualizada por parte da administração, que ao se utilizar das padronizações converte a tributação individual em tributação pela média, transformando a legalidade do caso concreto em legalidade do caso padrão. ${ }^{48}$

Eis aí o dilema entre a praticabilidade e a legalidade que surge pela utilização das padronizações, em prol do atendimento desta necessidade de economia administrativa, substituindo a aplicação individualizada da norma no caso concreto pela aplicação aos casos normal, médio ou esquemático.

MisABEl DERZI ${ }^{49}$ não tem dúvidas: "O dilema entre legalidade e praticidade é resolvido em favor do segundo princípio".

Ousamos discordar de tal posicionamento, em razão de acreditarmos que o conflito entre princípios não se resolve pela regra "do tudo ou nada”, mas por sua ponderação, isto é, pelo sopesamento dos pesos relativos de cada princípio encontra-se qual deles deverá prevalecer.

Neste caso, é necessário investigar se a legalidade ou tipicidade não sofre mitigações, frente a outros valores justificados pela praticabilidade.

Uma idolatria do tratamento particularizado que busque detalhar minuciosamente todos as possíveis situações de fato, inevitavelmente implicará numa legislação tributária complexa e inteligível, repleta de regras especiais e excepcionais que em nada colaboram para a racionalidade do sistema.

Essa individualização exacerbada em oposição à generalidade da lei representa uma violação ao princípio da igualdade ${ }^{50}$ pelo "fato de a lei, ao pretender tratar cada um diferentemente, gera uma dificuldade soberba para ser aplicada por todos". ${ }^{51}$

\footnotetext{
${ }^{48}$ DERZI, Misabel de Abreu Machado. Direito tributário, direito penal e tipo, 2. ed. São Paulo: Revista dos Tribunais, 2008, p. 356.

${ }^{49}$ Segundo a autora: "Diante do estado de necessidade administrativo, da oposição entre legalidade e praticidade, para doutrinadores com Arndt ou Isensee, o modo de pensar que denominam 'tipificante' aparece com uma tentativa de solução do impasse. A criação de pauta de valores ou padrões rígidos atribui prevalência à quantidade sobre a qualidade, afrouxando o princípio da legalidade, em nome da economia administrativa e substituindo a aplicação da norma ao caso individual concreto pela aplicação da norma ao caso 'normal', esquemático". DERZI, Misabel de Abreu Machado. Direito tributário, direito penal e tipo, 2. ed. São Paulo: Revista dos Tribunais, 2008, p. 340.

50 "É que a lei, para tratar todos os contribuintes da mesma forma, precisa, por definição, desconsiderar detalhes. Isso se deve, entre tantos motivos, ao fato de que o tratamento minucioso terminaria por inviabilizar o próprio tratamento individualizado para a maioria dos casos. Quando as leis diferenciam demais e se tornam, por isso, tão complexas que não podem ser observadas nem pelos contribuintes nem pelas autoridades fiscais, a análise individual não garante sequer a igualdade de tratamento, pois as leis não serão, na prática, aplicadas de modo isonômico". ÁVILA, Humberto. Teoria da Igualdade Tributária. $2^{a}$. edição. São Paulo: Malheiros, 2009, p. 116.

${ }^{51}$ Ibidem, p. 115.
} 
Esse paradoxo entre a individualização ao máximo da lei e a arbitrariedade que isso pode trazer foi bem observada por HUMBERTO ÁvILA: "para permitir a avaliação das diferenças entre os contribuintes, são eliminados os padrões em favor da consideração mais individualizada; essa, contudo, pela ausência de padrões, permite o uso discricionário pelas autoridades, livres para diferenciar os contribuintes, inclusive sem motivos ou por motivos discriminatórios". 52

CASAltA NABAIS ${ }^{53}$ também enxerga o efeito indesejável de uma maior indeterminação, em razão do detalhamento excessivo das normas, por obediência ao princípio da tipicidade ou da determinabilidade legal dos impostos:

[...] não se confunde com um suposto dever de pormenorizar o mais possível ou de otimizar a pormenorização da disciplina dos impostos, uma vez que, quanto mais o legislador tenta pormenorizar, maiores lacunas acaba por originar relativamente aos aspectos que ficam à margem dessa disciplina, aspectos estes que, como facilmente se compreende, variarão na razão inversa daquela pormenorização. Ou seja, as especificações excessivas, porque se enredam na riqueza dos pormenores, perdem o plano de que partiram, acabando, ao invés por conduzir a maior indeterminação.

Por isso mesmo, ele entende necessárias as padronizações ou tipificações que realizarão por lei, "uma igualdade formal de situações diversas, desde que, como correctivo, permita a administração a dispensa do respeito pelo tipo legal naquelas hipóteses, em que a observância estrita do mesmo, conduz a situações de manifesta iniquidade". ${ }^{54}$

Cabe, porém, a advertência que as diversas formas de simplificação na execução da lei, levadas a cabo pelo princípio da praticabilidade, devem ser habilitadas pelo legislador "apenas relativamente a situações verdadeiramente excepcionais" ${ }_{55}$, sob o risco que poderá advir da "aceitação de um estado de necessidade permanente ou crónico dada a eterna carência de meios humanos e materiais da administração fiscal, ou, por outras palavras, em a 'ilegalidade necessária' se tornar numa 'ilegalidade habitual'". ${ }^{56}$

Na mesma linha de raciocínio, EDUARDO MANEIRA pondera que a praticabilidade “é um atributo da legalidade, no sentido de que a lei deve ser exequível e de possível aplicação prática” ${ }_{57}$ e conclui: “A praticidade como princípio autônomo é princípio vazio, sem conteúdo;

\footnotetext{
52 ÁVILA, Humberto. Teoria da Igualdade Tributária. 2a . edição. São Paulo: Malheiros, 2009, p. 117.

${ }^{53}$ NABAIS, José Casalta. O Dever Fundamental de Pagar Imposto - Contributo para a compreensão constitucional do estado fiscal contemporâneo. 3. ed. Coimbra: Almedina, 2012, p. 377.

${ }^{54}$ Ibidem, p. 377-378.

${ }_{55}^{5}$ NABAIS, José Casalta. O Dever Fundamental de Pagar Imposto - Contributo para a compreensão constitucional do estado fiscal contemporâneo. 3. ed. Coimbra: Almedina, 2012, p. 377.

${ }^{56}$ Ibidem, p. 377.

${ }^{57}$ MANEIRA, Eduardo. Princípio da legalidade: especificação conceitual x tipicidade. Revista Internacional de Direito Tributário, v. 2. Minas Gerais: Del Rey, julho/dezembro de 2004, p. 48.
} 
a sua razão de ser é a de garantir a aplicabilidade da lei, por meio de técnicas de simplificação que possibilitam alcançar realidades de natureza complexa". ${ }^{58}$

Como mencionamos anteriormente, um dos principais instrumentos a serviço da praticabilidade está na fixação de uma base de cálculo presumida.

A base de cálculo de qualquer tributo, pelo mandamento da legalidade, deve ser fixada por lei ordinária, mas cabe distinguir a base de cálculo in abstracto da base de cálculo in concreto.

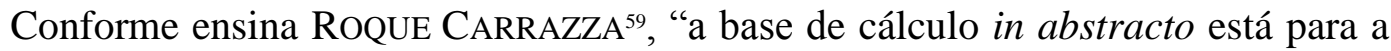
hipótese de incidência do tributo (fato gerador in abstracto) assim como a base de cálculo in concreto está para o fato imponível (fato gerador in concreto)".

A base de cálculo in abstracto, criada por lei, é da competência privativa do legislativo, enquanto a base de cálculo in concreto é determinação de seu valor pelo ato de lançamento de competência privativa do poder executivo.

A esse respeito, muito oportunas as reflexões de Geraldo AtALIBA ${ }^{60}$ :

Confirma-se, aí, que à lei cabe definir a base de cálculo dos tributos, mas não fixar o valor da coisa objeto da tributação em cada caso. Esta é tarefa administrativa. Lei é norma genérica, abstrata e impessoal. A lei não cuida de casos concretos, mas de hipóteses. Ao executivo cabe, mediante ação administrativa, aplicar as normas gerais aos casos praticados. $\mathrm{O}$ aplicador é que enfrenta o fato em sua previsão normativa e aplica a lei. $\mathrm{O}$ ato administrativo é sempre concretização do comando abstrato e legal $[\ldots]$.

A administração ao ter que enfrentar ofato, ou melhor dizendo, ao ter que enfrentar milhares de fatos individualizados, fica obrigada a mitigar a tipicidade cerrada, simplificando, por exemplo, a base de cálculo na aplicação da lei, ou como denuncia SPERB DE PAOLA: “A tipicidade, no que toca ao momento de aplicação da norma, impõe ao administrador a caracterização mais aproximada possível, nos limites do razoável, dos aspectos que compõem o tipo". ${ }^{61}$

O tipo, ou a tipicidade, é a garantia que todos os casos, no âmbito de suas igualdades sejam tratados de maneira equânime, ao determinar de forma objetiva todos os critérios juridicamente relevantes a fim de que a liberdade do aplicador no momento da expedição de normas individuais e concretas seja a menor possível, não se abrindo espaço para a discricionariedade administrativa. ${ }^{62}$

\footnotetext{
58 MANEIRA, Eduardo. Princípio da legalidade: especificação conceitual x tipicidade. Revista Internacional de Direito Tributário, v. 2. Minas Gerais: Del Rey, julho/dezembro de 2004, p. 48.

${ }^{59}$ CARRAZZA, Roque Antonio. Curso de Direito Constitucional Tributário. 22. ed. São Paulo: Malheiros, 2006, p. 254.

${ }^{60}$ ATALIBA, Geraldo. Imposto predial e taxas urbanas. Revista de Direito Processual, n. 11, p. 119.

${ }^{61}$ PAOLA, Leonardo Sperb de. Presunções e ficções no direito tributário. Belo Horizonte: Del Rey, 1997, p. 162.

${ }^{62}$ Assim a doutrina: "O princípio da determinação ou da tipicidade cerrada (o Grundsatz der Bestimmtheit que fala Friedrich) exige que os elementos integrantes do tipo sejam de tal modo precisos e determinados na sua formulação legal que o órgão de
} 
As normas de simplificação visam justamente garantir essa aplicação uniforme da lei para todos. Como em determinados casos, por exemplo, a apuração da base de cálculo in abstracto mostra-se inviável, a própria lei permite, pelo uso de presunções e ficções, a aplicação de uma base de cálculo in concreto, fazendo o uso de médias e índices, que permitirão alcançar a maior parte dos contribuintes e, por conseguinte, a realização da igualdade geral.

Cabe a ressalva de "que a existência de presunções legais absolutas ao lado de normas substanciais tributárias pode tornar o sistema mais confuso e de mais difícil operacionalização, mas isso não é razão suficiente para que elas, presunções sejam inquinadas de ofensivas ao princípio da legalidade". ${ }^{63}$

Conforme salientamos, o princípio da legalidade no aspecto formal demanda que somente a lei seja o veículo adequado para as imposições tributárias, ou seja, à administração cabe o dever de lançar, arrecadar e fiscalizar os tributos que estiverem expressamente previstos em lei.

Ocorre que pelo princípio da praticabilidade, muitas vezes são utilizadas presunções tais como pauta de valores, mapa genéricos de valores, tabelas de valores de veículos etc., expedidas em atos infralegais (decretos, portarias, regulamentos) e não por uma lei formalmente expedida.

Essa prática é condenada por ROQUE CARRAZZA ${ }^{64}$ quando afirma que: “Apenas à lei - e não ao ato infralegal - está reservado interferir na liberdade, na propriedade e nos demais direitos dos contribuintes, bem como impor-lhes deveres, exigindo-lhes um fazer concreto, um suportar ou um omitir. E ainda assim, nos termos da Constituição”.

Impende destacar, conforme leciona MISABEL DERZI ${ }^{65}$, que a execução simplificadora utiliza-se de abstrações conceituais generalizantes fechadas, visando à segurança ou à praticidade, que pode ocorrer tanto no plano horizontal como no plano vertical.

No plano horizontal, a inserção de presunções legais ocorre na própria lei formal, ou seja, há uma tipificação prévia da lei ao acolher o caso padrão médio social, ou frequente, mas para reforçar a segurança ou garantir a praticabilidade acaba por fechar o tipo, como ordem

\footnotetext{
aplicação do direito não possa traduzir critérios subjetivos de apreciação na sua aplicação concreta. Por outras palavras: exige a utilização de conceitos determinados, entendendo-se por estes (e tendo em vista a indeterminação imanente a todo o conceito) aqueles que não afetam a segurança jurídica dos cidadãos, isto é, a sua capacidade de previsão objetiva dos seus direitos e deveres tributários". XAVIER, Alberto. Tipicidade da tributação, simulação e norma elisiva. São Paulo: Dialética, 2001, p. 19.

${ }^{63}$ PAOLA, Leonardo Sperb de. Presunções e ficções no direito tributário. Belo Horizonte: Del Rey, 1997, p. 163-164.

${ }^{64}$ CARRAZZA, Roque Antonio. Curso de Direito Constitucional Tributário. 22. ed. São Paulo: Malheiros, 2006, p. 261.

${ }^{65}$ DERZI, Misabel de Abreu Machado. Direito tributário, direito penal e tipo, 2. ed. São Paulo: Revista dos Tribunais, 2008, p. 140 e $320-326$.
} 
de estrutura flexível e aberta, por uma conceitualização abstrata e determinada (iures et de iure), quantificando em número fixo que despreza as diferenças individuais, exceções e casos-limite. ${ }^{66}$ Partindo do pressuposto que a praticidade "é vocação inata e necessária da lei, a qual nasce para ser cumprida" ${ }^{67}$, do ponto de vista horizontal, são amplamente admitidas em regra as presunções e padronizações legais criadas por lei, "respeitados os princípios que vedam o confisco, asseguram a igualdade e a livre iniciativa". ${ }^{68}$

A execução simplificada no sentido vertical ocorre quando os regulamentos do executivo ou outras normas administrativas internas estabelecem abstrações generalizantes, com o objetivo de possibilitar a execução de norma hierarquicamente superior, sem previsão da lei formal para tanto.

No sentido vertical ${ }^{69}$ buscam-se identificar "as transformações por que passam as normas constitucionais quando simplificadas, reduzidas ou ampliadas nas leis que as executam, assim como a execução simplificadora que normas administrativas empreendem nas leis que o Poder Executivo deve aplicar", ${ }^{70}$

Por entender que somente a lei pode presumir ou esquematizar, esta execução simplificadora no plano vertical, "seja em nível legal, seja regulamentar, ao contrário da anterior, horizontal, tende à inconstitucionalidade" ${ }^{\prime 1}$, representa uma quebra do princípio da legalidade.

A solução, no seu entender, é que as tabelas de valores expedidas pelo Executivo devem funcionar como um critério norteador da avaliação e não como uma avaliação final e definitiva. Como garantia mínima do contribuinte, funcionam "como quadro de valores primários e básicos sobre os quais devem ser aplicados quantificadores individuais, que

\footnotetext{
${ }^{66}$ Assim a doutrina: "Em geral, na eleição desses recursos que objetivam alcançar a segurança jurídica, uniformidade, garantia, fortalecimento do crédito tributário e praticidade, o legislador se vale do tipo, deduzindo-o daquilo que é padrão usual, médio ou frequente mas, em regra, desnatura-o, transformando-o em conceito fechado ou quantificando-o". DERZI, Misabel de Abreu Machado. Direito tributário, direito penal e tipo, 2. ed. São Paulo: Revista dos Tribunais, 2008, p. 326.

${ }^{67}$ DERZI, Misabel de Abreu Machado. Direito tributário, direito penal e tipo, 2. ed. São Paulo: Revista dos Tribunais, 2008, p. 325.

${ }^{68}$ DERZI, Misabel de Abreu Machado. Direito tributário, direito penal e tipo, 2. ed. São Paulo: Revista dos Tribunais, 2008, p. 326.

${ }^{69}$ Misabel Derzi ao tratar do fenômeno da incidência no plano vertical assim doutrinou: "O objetivo não é analisar o fenômeno no plano horizontal, mas vertical. Tomando como base a hierarquia das normas, é útil questionar a validade da norma inferior que estabelece abstrações, tipos ou presunções com o objetivo de possibilitar a execução de norma hierarquicamente superior. Trata-se de investigar as esquematizações, as abstrações generalizantes (sejam tipos ou conceitos fechados) que têm como fim simplificar a execução das normas de tributação. O ângulo de análise aqui é diverso, pois se considera como relevante a relação entre norma exequente e norma a executar. A norma executiva contém, muitas vezes, presunções, ficções e esquemas (que, em geral, se convertem em conceitos fechados), em regra não autorizados pela norma superior, mas úteis à sua execução. A análise, que ora se faz, considera exatamente as esquematizações, abstrações e generalizações (tipificações e conceitualizações) que a norma inferior, ao executar a superior, em nome da praticidade, faz ou pode fazer. Por essa razão, exatamente naqueles ramos jurídicos, onde compete a órgão estatal executar a norma em massa, é que se coloca de forma mais aguda a questão da praticidade e de seus limites". DERZI, Misabel De AbReu MAChado. Direito tributário, direito penal e tipo, 2. ed. São Paulo: Revista dos Tribunais, 2008, p. 320.

${ }^{70}$ Ibidem, p. 326.

${ }^{71}$ Ibidem, p. 326.
} 
aproximem o lançamento de cada avaliação ao efetivo valor de mercado. Isso se se quiser cumprir o comando legal". ${ }^{72}$

Esta solução apresentada pela autora, embora tente resguardar a tipicidade cerrada como valor absoluto, não iria solucionar a dificuldade encontrada pela administração na apuração da real base de cálculo em milhares de situação individualizadas.

Desde que o valor presumido da base de cálculo reflita realmente um valor padronizado médio e que essas presunções também estejam previstas na lei instituidora do tributo $^{73}$, não visualizamos óbice à sua utilização, desde que garantido o direito de impugnar o lançamento para o reduzido número de casos de contribuintes atípicos que escapem da normalidade.

Para ratificar esse entendimento, reproduzimos as considerações de Leonardo SPERB DE PAOLA ${ }^{74}$ sobre esse tema:

[...] nenhum princípio tem seu programa exaurido, levado às últimas consequências. Há que se estabelecer a convivência entre princípios cuja aplicação unilateral leva a resultados opostos e inconciliáveis. Parece-nos correta a afirmação de que a legalidade impõe, como um de seus corolários, a caracterização concreta, da melhor forma possível, dos fatos descritos abstratamente em lei. Isso, entretanto, não quer significar que o administrador, ao aplicar a norma, não possa valer-se de presunções, mas, apenas, que essa utilização é condicionada. As padronizações (caso das plantas de valores), assim, podem, embora vertidas em regulamentos, ser tomadas como presunções simples, contra as quais, em se tratando de lançamento de ofício, o contribuinte poderá arremeter-se, obrigando, por mera impugnação, o administrador a proceder uma investigação mais exaustiva da realidade tributável.

O primado da praticabilidade não ofende e muito menos ignora o princípio da legalidade, valor supremo em nossa Constituição, mas nele operam atenuações ao reduzir o excesso de pormenorizações que a tipificação cerrada suscita, sopesando-o com outros valores constitucionais também valiosos de uma tributação harmoniosa, generalizada e eficaz, garantidos pela exequibilidade das normas fiscais.

\footnotetext{
${ }^{72}$ DERZI, Misabel de AbReu MAChado. Direito tributário, direito penal e tipo, 2. ed. São Paulo: Revista dos Tribunais, 2008, p. 356.

73 Assim a doutrina: “[...] as hipóteses presuntivas devem insurgir-se no instante mesmo da publicação da lei que institui elementos suficientes que caracterizem presumidamente uma ação, num dado tempo e espaço, e, ademais, o vínculo que esta mantém com o tipo tributário ou o fato jurídico em sentido estrito. Eis as condições mínimas da presunção hipotética na oportunidade da expedição da regra pelo legislador. Faltando um desses critérios, a norma deverá ser considerada insuficiente para ensejar o tributo, devendo ser declarada inconstitucional por descumprimento do princípio da legalidade material pelo legislador". HARET, Florence. Teoria e Prática das Presunções no Direito Tributário. São Paulo: Noeses, 2011, p. 585-586. ${ }^{74}$ PAOLA, Leonardo Sperb de. Presunções e ficções no direito tributário. Belo Horizonte: Del Rey, 1997, p. 173.
} 


\subsection{Igualdade}

Em razão de sua alta intensidade axiológica, o princípio da igualdade é denominado por parte da doutrina ${ }^{75}$ sobreprincípio no sistema jurídico tributário.

Trata-se de preceito expresso no art. $5^{\circ}$, caput, da Constituição Federal: “Todos são iguais perante a lei, sem distinção de qualquer natureza, garantindo-se aos brasileiros e aos estrangeiros residentes no país, a inviolabilidade do direito à vida, à liberdade, à segurança e à propriedade (...)".

No âmbito fiscal encontramos a prescrição do artigo 150, II, também da Constituição vedando à União, Estados, Distrito Federal e Municípios “instituir tratamento desigual entre contribuintes que se encontrem em situação equivalente, proibida qualquer distinção em razão de ocupação profissional ou função por eles exercida, independentemente da denominação jurídica dos rendimentos, títulos ou direitos".

A igualdade não implica em dar a todos o mesmo tratamento, mas garantir a equiparação normativa a todos que se encontram em situações idênticas, ou em outras palavras, deve-se tratar igualmente os iguais e desigualmente os desiguais, na medida de sua desigualdade, conforme a clássica lição de RUY BARBOSA76:

A regra da igualdade não consiste senão em quinhoar desigualmente aos desiguais, na medida em que se desigualam. Nesta desigualdade social, proporcionada à desigualdade natural, é que se acha a verdadeira lei da igualdade.

Os principais destinatários deste princípio são o legislador e aplicador. O primeiro deverá, tendo em conta "as notas singulares das diversas classes de sujeitos passivos, eleger fatos distintivos que sejam hábeis para atender às especificidades dos casos submetidos à imposição, de tal maneira que se mantenha a correspondente equivalência entre as múltiplas situações empíricas sobre as quais haverá de incidir a percussão tributária". ${ }^{77}$

Ao aplicador, a igualdade veda a diferenciação das pessoas, juridicamente iguais, submetendo-as aos efeitos normativos diversos.

LUCIANO AMARO ${ }^{78}$ sintetiza que "nem pode o aplicador, diante da lei, discriminar, nem autoriza o legislador, ao ditar a lei, a fazer discriminações. Visa o princípio à garantia do indivíduo, evitando perseguições e favoritismos".

\footnotetext{
${ }^{75}$ CARVAlHO, Paulo de Barros. Direito Tributário Linguagem e Método. 3. ed. São Paulo: Noeses, 2009. p. 269.

${ }^{76}$ BARBOSA, Ruy. Oração aos moços. São Paulo: Martin Claret, 2003, p. 19.

${ }^{77}$ CARVALHO, Paulo de Barros. Direito Tributário Linguagem e Método. 3. ed. São Paulo: Noeses, 2009. p. 277.

${ }^{78}$ AMARO, Luciano. Direito Tributário Brasileiro. 15ª edição. São Paulo: Saraiva, 2009, p. 135.
} 
Se "o princípio da igualdade é inimigo de privilégios" de discriminação em situações equivalentes, exsurge a necessidade de encontrar um critério diferenciador para selecionar estas situações equivalentes e dar-lhes tratamento diferenciado.

A necessidade deste critério também foi apontada por KLAUS TIPKE:

\begin{abstract}
A igualdade que se distingue da identidade, é sempre relativa. O que é completamente igual é idêntico. O princípio de que o igual deve ser tratado igualmente não quer dizer idêntico, mas relativamente igual. Quando se pretende aplicar corretamente o princípio da igualdade, deve-se apurar a exata relação, perguntando-se igual em relação a quê (em que relação)? Quaisquer diferenças podem, pois, não justificar o tratamento desigual. Para a comparação relativa torna-se necessário um critério de comparação. Logra-se extrair um critério concreto de comparação do princípio de sistematização, isto é, do motivo ou da valoração que constitui o fundamento da lei. O princípio é o critério de comparação ou de justiça estabelecido compulsoriamente pelo legislador para determinados assuntos legalmente disciplinados. ${ }^{80}$
\end{abstract}

Portanto, quando se fala da igualdade, é a igualdade em relação a um determinado critério comparativo. A escolha deste critério pelo legislador deve manter uma correlação lógica com a desequiparação pretendida e que este discrímen seja pertinente com os valores preservados pela Constituição. ${ }^{81}$

Em matéria tributária, a própria Constituição ao dispor sobre o princípio da igualdade, trata da necessidade de fixação de um discrimen para identificar contribuintes em “situação equivalente". É o que se depreende do artigo 150, II que veda à União, aos Estados, ao Distrito Federal e aos Municípios "instituir tratamento desigual entre contribuintes que se encontrem em situação equivalente".

Tratar de forma desigual, sem motivo razoável, é agredir o princípio da igualdade. "Não basta tratar diferentemente os desiguais. É preciso que o tratamento diferenciado dê-se em razão dessa diferença, ou seja, que o tratamento diferenciado tenha relação com o critério discriminante eleito" "2, "ou seja, o critério eleito deve ser adequado para identificar motivação suficiente para o tratamento diferenciado". 83

\footnotetext{
${ }^{79}$ TIPKE, Klaus. Princípios de Igualdade e ideia de sistema no Direito Tributário. In: MACHADO, Brandão (coord.). Direito Tributário-Estudos em homenagem ao professor Ruy Barbosa Nogueira. São Paulo: Saraiva, 1984, p. 517.

${ }^{80}$ TIPKE, Klaus. Princípios de Igualdade e ideia de sistema no Direito Tributário. In: MACHADO, Brandão (coord.). Direito Tributário-Estudos em homenagem ao professor Ruy Barbosa Nogueira. São Paulo: Saraiva, 1984, p. 519-520.

${ }^{81}$ Assim a doutrina: "há ofensa ao preceito constitucional da isonomia quando (...) a norma atribui tratamento jurídico diferente em atenção a fator de discrímen adotado que, entretanto, não guarda relação de pertinência lógica com a disparidade de regimes outorgados (...)", e quando "a norma supõe relação de pertinência lógica existente em abstrato, mas o discrímen estabelecido conduz a efeitos contrapostos ou de qualquer modo dissonantes prestigiados constitucionalmente". BANDEIRA DE MELLO, Celso. O Conteúdo Jurídico do Princípio da Igualdade.3.ed. São Paulo: Malheiros, 2002, p. 47.

${ }^{82}$ CARVALHO, Paulo de Barros. Direito Tributário Linguagem e Método. 3. ed. São Paulo: Noeses, 2009. p. 280.

${ }^{83}$ SCHOUERI, Luís Eduardo. Direito Tributário. São Paulo: Saraiva, 2011, p. 310.
} 
Celso Antonio Bandeira de Mello $^{84}$ aponta os quatro requisitos a serem atendidos para que seja admitido um fator de discrímen, sem agressão ao princípio da igualdade:

1) que a discriminação não atinja de modo atual e absoluto um só indivíduo; 2) que o fator de desigualação consista num traço diferencial residente nas pessoas ou situações, vale dizer, que não lhes seja alheio; 3) que exista um nexo lógico entre o fator de discrímen e a discriminação legal estabelecida em razão dele; e 4) que, no caso concreto, tal vínculo de correlação seja pertinente em função dos interesses constitucionalmente protegidos, visando ao bem público, à luz do texto constitucional.

LUÍS EDUARDO SCHOUERI ${ }^{85}$ destaca que, embora o legislador tenha liberdade ampla em matéria tributária para a adoção deste critério de comparação, uma vez adotado, o mesmo deverá ser mantido com coerência, sob pena de afronta ao princípio da igualdade.

Essa coerência na adoção do critério de comparação, segundo Klaus Tipke, atende ao princípio formal de justiça, pelo qual o legislador "É livre até para fixar os princípios fundamentais da Justiça, mas não é tão soberano a ponto de anular a coerência que resulta dos valores. O princípio da igualdade impede exatamente isso. Exige que os princípios estabelecidos sejam aplicados coerentemente, isto é, que os valores sejam racionalmente atendidos". .86

LEONARDo SPERb DE PAOLA assevera que essa liberdade do legislador é limitada materialmente pelo princípio da igualdade, porquanto ele "não pode criar equivalências jurídicas entre fatos que não encontrem algum correspondência na realidade". ${ }^{87}$

Segundo doutrina, a semelhança não pode ser criação do mundo jurídico por meio de presunções ou ficções, ela tem que existir da realidade, sob pena da desconsideração da igualdade. 88

A igualdade está intimamente relacionada com a realização da justiça. Ao tributar diferentemente situações semelhantes, por não atender ao critério selecionado coerentemente, não se atinge a segurança jurídica e impede a realização do primado da justiça.

\footnotetext{
${ }^{84}$ BANDEIRA DE MELLO, Celso. O Conteúdo Jurídico do Princípio da Igualdade.3.ed. São Paulo: Malheiros, 2002, p. $37-$ 38.

85 “Assim o Princípio da Igualdade encontra-se desatendido quando situações iguais (segundo um critério) são tratadas de modo diferente, do mesmo modo pode-se considerar ferido o Princípio da Igualdade quando não se consegue identificar um critério para o tratamento diferenciado. Neste caso, dir-se-á que houve arbítrio e, portanto, igualmente foi ferido o Princípio da Igualdade”. SCHOUERI, Luís Eduardo. Direito Tributário. São Paulo: Saraiva, 2011, p. 309.

${ }^{86}$ TIPKE, Klaus. Princípios de Igualdade e ideia de sistema no Direito Tributário. In: MACHADO, Brandão (coord.). Direito Tributário-Estudos em homenagem ao professor Ruy Barbosa Nogueira. São Paulo: Saraiva, 1984, p. 520.

${ }^{87}$ PAOLA, Leonardo Sperb de. Presunções e ficções no direito tributário. Belo Horizonte: Del Rey, 1997, p. 135.

88 "Em termos jurídico-positivos, é o princípio da igualdade o mais importante limite material à liberdade do legislador. Ele atenua ou reduz o hiato entre o mundo do ser e o mundo do dever-ser". PAOLA, Leonardo Sperb de. Presunções e ficções no direito tributário. Belo Horizonte: Del Rey, 1997, p. 135. No mesmo sentido: "O legislador, como poeta do direito, a princípio pode criar a realidade jurídica que quiser. Contudo, em face das garantias constitucionais no campo tributário, deverá fazê-lo em atenção, entre outros princípios, à capacidade contributiva absoluta ou objetiva". HARET, Florence. Teoria e Prática das Presunções no Direito Tributário. São Paulo: Noeses, 2011, p. 601.
} 
Se a realização da justiça é justamente tributar os semelhantes, adotado um critério de diferenciação, de forma igual, poderá a administração, pelas mais variadas razões, deixar de aplicar a norma tributária a todos, ou tributar uma classe de contribuintes e deixar de tributar outra, em razão de dificuldades práticas?

Para responder essa questão, vamos inicialmente investigar qual o discrimem utilizado na tributação, para então vislumbrar se a praticabilidade está em sintonia com a igualdade e justiça. 


\subsection{Capacidade Contributiva}

Quando se fala da igualdade, é a igualdade em relação a um determinado critério comparativo. Desta forma para a realização do princípio da igualdade faz-se necessário a adoção de um critério de comparação pelo legislador, o qual uma vez eleito será utilizado para comparar as situações semelhantes.

No caso dos gastos a serem suportados por toda a coletividade, todos são beneficiados, de forma que, cada um deverá colaborar, dentro de suas condições, para o bem coletivo. O critério de diferenciação neste caso será identificar quem pode contribuir, ou seja, em nome do princípio da solidariedade, insculpido no art. $3^{\circ}$, I, da Constituição Federal, "que se afirma que o critério aceitável para a diferenciação dos contribuintes será aquele que atingir a máxima: cada um contribuirá com quanto puder para o bem de todos". ${ }^{89}$

Esse princípio da solidariedade, na seara do direito tributário, é encontrado no princípio da capacidade contributiva, consagrado no art. $145, \S 1^{\circ}$., da Carta Magna ${ }^{90}$, configurando-se como critério diferenciador, em atendimento ao princípio da igualdade, entre os que têm e os que não têm capacidade de contribuir no rateio dos gastos públicos.

Como parte da doutrina entende que capacidade contributiva é tema da ciência das finanças e não tema jurídico na seara do direito tributário, ela tornou-se um tema tormentoso sobre o qual há muita discussão e debates infindáveis.

PAUlO DE BARRos CARVAlHo afirma que "um dos temas que mais atormenta a dogmática jurídica é a discussão sobre a natureza jurídica da famosa capacidade contributiva"91 e BECKER ressalta que a ambiguidade da locução, ressaltada tanto pela ciência das finanças como pelo direito tributário, "aumenta os seus funestíssimos efeitos que tumultuam e obscurecem o desenvolvimento racional de ambas as ciências, constituindo, por si mesma, um foco gerador de obscurantismo"92, chegando ao ponto de afirmar que a canonização do princípio da capacidade contributiva pelas modernas constituições "É a constitucionalização do equívoco". ${ }^{93}$

\footnotetext{
${ }^{89}$ SCHOUERI, Luís Eduardo. Direito Tributário. São Paulo: Saraiva, 2011, p. 311.

${ }^{90}$ Art. $145, \S 1^{\circ}$.: "Sempre que possível, os impostos terão caráter pessoal e serão graduados segundo a capacidade econômica do contribuinte, facultado à administração tributária, especialmente para conferir efetividade a esses objetivos, identificar, respeitados os direitos individuais e nos termos da lei, o patrimônio, os rendimentos e as atividades econômicas do contribuinte".

${ }^{91}$ CARVALHO, Paulo de Barros. Direito Tributário Linguagem e Método. 3. ed. São Paulo: Noeses, 2009. p. 324.

92 BECKER, Alfredo Augusto. Teoria geral do direito tributário. 5.ed. São Paulo: Noeses, 2010, p. 515.

93 BECKER, Alfredo Augusto. Teoria geral do direito tributário. 5.ed. São Paulo: Noeses, 2010, p. 518.
} 
A capacidade contributiva, na definição de FERNANDO ZILVETTI: “É o princípio segundo o qual cada cidadão deve contribuir para as despesas públicas na exata proporção de sua capacidade econômica". ${ }^{94}$

A capacidade de contribuir como critério válido para alcançar a igualdade tributária também foi a conclusão de ALCIDES JORGE COSTA ${ }^{95}$, que assim proferiu:

\begin{abstract}
A igualdade tributária consiste em tributar do mesmo modo todos os cidadãos de uma mesma categoria essencial, igualdade tributária, no Brasil, consiste em tributar da mesma forma todos os que têm a mesma capacidade contributiva. A categoria essencial a considerar é a capacidade contributiva, o que leva a perguntar o que é capacidade contributiva. Esta é a capacidade de suportar uma parcela dos encargos públicos.
\end{abstract}

O critério segundo o qual, quanto maior a riqueza, maior a carga tributária, em razão da capacidade contributiva, atende à necessidade de que "as discriminações efetuadas pela lei tributária apresentem relação de causalidade entre o discrímen eleito e a distinção procedida em razão dele". ${ }^{96}$

A capacidade contributiva "como critério ético da imposição tributária, porquanto responde aos reclamos da justiça tributária, voltada à minimização das disparidades sociais e econômicas" ${ }^{97}$, decorre do princípio da isonomia, embora não esgote seu conteúdo. ${ }^{98}$

Na esteira desse pensamento, ROQUE ANTONIO CARRAZZA"99, para quem “o princípio da capacidade contributiva hospeda-se nas dobras do princípio da igualdade e ajuda a realizar, no campo tributário, os ideais republicanos", pondera que como o princípio da capacidade contributiva está "intimamente ligado ao princípio da igualdade, é um dos mecanismos mais eficazes para que se alcance a tão almejada Justiça Fiscal”.

Importante destacar a distinção entre a capacidade contributiva absoluta ou objetiva e a capacidade contributiva relativa ou subjetiva adotada pela doutrina.

A capacidade contributiva absoluta ou objetiva pode ser tida como um parâmetro que distingue situações tributáveis e não tributáveis ${ }^{100}$, como atividade de eleição pelo legislador

\footnotetext{
${ }^{94}$ ZILVETTI, Fernando Aurélio. Capacidade contributiva e mínimo existencial. Luís Eduardo Schoueri; ZILVETTI, Fernando Aurélio (coords.). Direito Tributário. Estudos em homenagem a Brandão Machado. São Paulo: Dialética, 1998, p. 36-47(38). ${ }^{95}$ COSTA, Alcides Jorge. Capacidade Contributiva. Revista de Direito Tributário, São Paulo, janeiro/março, 1991, n. 55, p. 300.

${ }^{96}$ COSTA, Regina Helena Costa. Princípio da Capacidade Contributiva. 3. ed. São Paulo: Malheiros, 2003. p. 42.

${ }^{97}$ COSTA, Regina Helena Costa. Princípio da Capacidade Contributiva. 3. ed. São Paulo: Malheiros, 2003. p. 26-27.

98 A professora, apresentando o posicionamento de Ernesto Lejeune Valcárcel, ressaltou que: "o princípio da capacidade contributiva é incapaz, por si só, de dar resposta às exigências do fenômeno tributário de nossos dias, ao passo que o princípio da igualdade permite superar com maior perfeição técnica as contradições que aquele implicaria se fosse convertido no único princípio diretor de todo o ordenamento jurídico". COSTA, Regina Helena Costa. Princípio da Capacidade Contributiva. 3. ed. São Paulo: Malheiros, 2003. p. 41.

${ }^{99}$ CARRAZZA, Roque Antonio. Curso de Direito Constitucional Tributário. 22. Ed. São Paulo: Malheiros, 2006, p. 86.

${ }^{100}$ SCHOUERI, Luís Eduardo. Direito Tributário. São Paulo: Saraiva, 2011, p. 312.
} 
de fatos que constituam numa manifestação de riqueza, fatos-signos presuntivos de riqueza, ou seja, eventos que demonstrem "a existência de um sujeito passivo em potencial"101 apto para concorrer às despesas públicas.

Por outro lado a capacidade relativa ou subjetiva como "um limite ou critério para a graduação da tributação"102, ou aptidão, de um sujeito individualmente considerado, de contribuir na medida de suas possibilidades econômicas. "Nesse plano, presente a capacidade contributiva in concreto, aquele potencial sujeito passivo torna-se efetivo - apto, pois, a absorver o impacto tributário". ${ }^{103}$

A capacidade contributiva subjetiva contempla, não apenas a existência de alguma riqueza, mas a parcela disponível desta riqueza para contribuir com as despesas públicas. Alguém que não tenha um saldo disponível além do mínimo existencial não pode ser compelido a contribuir com impostos, ou ainda com taxas, mesmo tendo sido ele o causador das despesas públicas, ou seja, o princípio da capacidade contributiva subjetiva não se limita aos impostos. ${ }^{104}$ Para PAULO DE BARROS CARVALHO ${ }^{105}$, a capacidade contributiva objetiva constituise em dever pré-jurídico de escolha pelo legislador de fatos signos de riqueza e, portanto, sem que se tenha qualquer preocupação na aplicação do princípio da igualdade.

A obediência ao primado da isonomia ocorrerá na capacidade contributiva subjetiva, com a qual o legislador irá dosar o impacto tributário de forma isonômica.

A capacidade contributiva subjetiva concretiza plenamente o princípio da igualdade na medida que possibilite dosar igualitariamente a carga impositiva, mas sua execução só se torna possível após a eleição pelo legislador de fatos que demonstrem objetivamente capacidade contributiva, isto é, após a satisfação do princípio da capacidade contributiva absoluta ou objetiva.

Embora a Constituição refira-se tão somente a impostos no art. 145, § $1^{\circ}$., a doutrina discute se outras espécies tributárias além dos impostos estariam sujeitas a esse mandamento.

LUÍS EDUARDO SCHOUERI ${ }^{106}$ assevera que a partir da justificação de cada tributo, encontra-se o critério adequado para a diferenciação em matéria de igualdade tributária: (i)

\footnotetext{
${ }^{101}$ COSTA, Regina Helena Costa. Princípio da Capacidade Contributiva. 3. ed. São Paulo: Malheiros, 2003. p. 27. 102 SCHOUERI, Luís Eduardo. Direito Tributário. São Paulo: Saraiva, 2011, p. 312.

${ }^{103}$ COSTA, Regina Helena Costa. Princípio da Capacidade Contributiva. 3. ed. São Paulo: Malheiros, 2003. p. 27.

104 SCHOUERI, Luís Eduardo. Direito Tributário. São Paulo: Saraiva, 2011, p. 313. Conforme o professor: "Mínimo existencial e confisco oferecem as balizas da capacidade contributiva, no sentido subjetivo, que começa além do mínimo necessário à existência humana digna e termina aquém do limite destruidor da propriedade”. Ibidem, p. 313.

105 Assim a doutrina: "Realizar o princípio pré-jurídico da capacidade contributiva absoluta ou objetiva retrata a eleição, pela autoridade legislativa competente, de fatos que ostentem signos de riqueza; por outro lado, tornar efetivo o princípio da capacidade contributiva relativa ou subjetiva quer expressar a repartição do impacto tributário, de tal modo que os participantes do acontecimentos contribuam de acordo com o tamanho econômico do evento". CARVALHO, Paulo de Barros. Direito Tributário Linguagem e Método. 3. ed. São Paulo: Noeses, 2009, p. 327.

${ }^{106}$ SCHOUERI, Luís Eduardo. Direito Tributário. São Paulo: Saraiva, 2011, p. 310.
} 
sinalagma para as taxas e contribuições de melhoria; e (ii) capacidade contributiva para os impostos, contribuições sociais e empréstimos compulsórios.

REginA HeLENA COSTA ${ }^{107}$ é da opinião que a igualdade traduz-se, no tocante a impostos, pelo respeito ao postulado da capacidade contributiva, enquanto nos tributos vinculados, revela-se pelo princípio da retributividade. As contribuições e os empréstimos compulsórios deverão observar o princípio da capacidade contributiva quando o aspecto material de sua hipótese de incidência não contiver uma vinculação à atuação estatal, configurando-se como impostos.

GERALDO ATALIBA ${ }^{108}$ pondera que os impostos são informados pelo princípio da capacidade contributiva, as taxas pelo princípio da remuneração e as contribuições por princípio diverso.

PAUlo Ayres BARRETO entende que como as contribuições têm por objetivo primeiro a partição de encargos comuns, elas não atendem necessariamente ao princípio da capacidade contributiva. No seu entender "nas hipóteses em que a materialidade da contribuição seja típica de imposto, a divisão do encargo ou despesa dentro do grupo pode ser feita a partir de escolha de base de cálculo que, a um só tempo, atenda ao princípio da capacidade contributiva e reflita a forma mais adequada de partilhar a despesa". ${ }^{109}$

PAUlO DE BARROS CARVALHO ${ }^{110}$ adota o posicionamento que todas as espécies tributárias no direito tributário brasileiro exibem observância ao princípio da capacidade contributiva objetiva, por apresentarem como hipóteses de incidência fatos que denotam signos de riqueza.

FLORENCE HARET opina que o princípio da capacidade contributiva é aplicável também a todas outras espécies tributárias, pois seria "um sem-sentido preservar a capacidade contributiva apenas para os impostos" 111 . Essa também a opinião de LEONARDO SPERB DE PAOLA ao afirmar que esse pressuposto constitucional não se aplica somente a "fatos estranhos à atividade estatal, pois também as taxas e contribuições especiais estão sujeitas ao princípio". ${ }^{112}$

\footnotetext{
${ }^{107}$ COSTA, Regina Helena Costa. Princípio da Capacidade Contributiva. 3. ed. São Paulo: Malheiros, 2003. p. 57-60.

${ }^{108}$ ATALIBA, Geraldo. Hipótese de Incidência Tributária. 6ª . edição. São Paulo: Malheiros, 2005, p. 111.

109 BARRETO, Paulo Ayres. Contribuições: regime jurídico, destinação e controle. São Paulo: Noeses, 2006. p. 144.

${ }^{110}$ Assim sua doutrina: "Em outras palavras, por capacidade contributiva deve entender-se apenas a absoluta e, mesmo assim, como dado pré-jurídico. Realizar o princípio da capacidade contributiva quer significar, portanto, a opção a que se entrega o legislador, quando elege para antecedente das normas tributárias fatos de conteúdo econômico que, por terem essa natureza, fazem pressupor que as pessoas que deles participam apresentem condições de colaborar com o Estado mediante parcelas de seu patrimônio". CARVALHO, Paulo de Barros. Direito Tributário Linguagem e Método. 3. ed. São Paulo: Noeses, 2009, p. 329.

${ }^{111}$ HARET, Florence. Teoria e Prática das Presunções no Direito Tributário. São Paulo: Noeses, 2011, p. 599.

112 PAOLA, Leonardo Sperb de. Presunções e ficções no direito tributário. Belo Horizonte: Del Rey, 1997, p. 139. O autor alerta que para taxas e contribuições especiais a capacidade contributiva não deve ser o único critério, devendo ser mesclada com outros.
} 
As exposições doutrinárias ressaltam a complexidade do tema, mas em nosso entendimento, com respeito aos que pensam de forma distinta, a tributação de manifestações de riqueza, como nos impostos, sujeitam-se ao princípio da capacidade contributiva, mas as hipóteses de incidência vinculadas à uma contraprestação estatal, nas quais os tributos configuram-se com verdadeiras remunerações e, não propriamente, uma manifestação de riqueza, o princípio informador será outro. ${ }^{113}$

\subsubsection{Capacidade Contributiva e Praticabilidade}

A capacidade contributiva, sob o prisma subjetivo, deve considerar quanto possível a situação individual de cada contribuinte.

LUÍ́ EDUARDO SCHOUERI ${ }^{114}$ denota essa necessidade imposta pelo princípio jurídico de buscar a capacidade contributiva "ideal" do ponto de vista subjetivo: "deve o legislador, na medida do possível (ou ao máximo possível), buscar a capacidade contributiva; a base de cálculo do tributo deve ser medida que atinja, do melhor modo possível aquela capacidade. Dentre duas bases de cálculo, o Princípio exigirá que se busque a mais exata”.

Essa busca do "máximo possível” da situação individual do contribuinte, num plano ideal, tornaria a tributação impraticável, razão pela qual, a doutrina preocupa-se mais com a eficácia da capacidade contributiva no aspecto objetivo. ${ }^{115}$

No aspecto subjetivo a preocupação maior é impor apenas os limites: mínimo, isto é, não se deve tributar o mínimo existencial; e máximo, evitando-se uma tributação confiscatória.

Parece-nos que ignorar o aspecto subjetivo do princípio da capacidade contributiva, face à dificuldade de sua aplicação, conflita com o próprio princípio da igualdade que se realiza efetivamente na seara tributária pela observância da feição subjetiva daquele mandamento constitucional.

Ante a inaplicabilidade do tributo, em razão da busca por uma adequação ideal da capacidade contributiva individualmente considerada, ou restringi-la considerando-se apenas

\footnotetext{
${ }^{113}$ A capacidade contributiva pode ser considerada na cobrança de taxas, ao não serem exigidas nos serviços públicos essenciais prestados às pessoas destituídas de capacidade contributiva, ou como diz o adágio, "Ninguém põe a mão no bolso de um homem nu". COSTA, Alcides Jorge. Capacidade Contributiva. Revista de Direito Tributário, São Paulo, janeiro/março, 1991, n. 55, p. 302.

${ }^{114}$ SCHOUERI, Luís Eduardo. Direito Tributário. São Paulo: Saraiva, 2011, p. 313.

${ }^{115}$ PAOLA, Leonardo Sperb de. Presunções e ficções no direito tributário. Belo Horizonte: Del Rey, 1997, p. 140.
} 
os limites máximo e mínimo, ficamos com a posição moderada de que “o importante é que, na média, haja obediência ao princípio, mesmo que em alguns casos, relativamente ao universo de contribuintes, configure-se excesso de tributação e, em outros, o contrário". ${ }^{116}$

Essa atenuação na consideração da situação individual do contribuinte em toda a riqueza de pormenores, não só por força de preceitos doutrinários, mas principalmente em razão de deficiências da máquina arrecadatória administrativa, impulsiona a busca por uma solução que contemple ao mesmo tempo a preservação do princípio da capacidade contributiva como desdobramento eficaz do primado da isonomia e a administração com instrumentos jurídicos hábeis a realizar a tributação de forma generalizada.

As padronizações, resultado do sopesamento entre a capacidade contributiva e a praticabilidade, representam verdadeiros instrumentos jurídicos hábeis a contemplar o princípio da igualdade no direito tributário, quando permitem realizar a tributação generalizada da riqueza.

LEONARDo SPERB DE PAOLA explica que o princípio da capacidade contributiva atua simultaneamente como: "uma norma geral de tributação e um limite à tributação; uma autorização para que o Estado capte os recursos necessários à realização de seus fins e uma imposição para que ele o faça de forma justa e generalizada. Protege-se o contribuinte e impõese-lhe um dever de solidariedade. Aí, parece-nos, o significado integral do princípio da capacidade contributiva". ${ }^{117}$

Esse dever de garantir que todos contribuam, dando efetividade à tributação, justifica em grande parte a mitigação da exatidão na busca da riqueza tributável, em favor da utilização de estandardizações, pois para que o princípio da capacidade contributiva seja atendido em sua totalidade requer que "a concreta conformação dos tipos tributários não deve apenas garantir os direitos dos contribuintes, mas, outrossim, possibilitar ao Estado, sem um ônus desproporcional, a arrecadação generalizada". ${ }^{118}$

A igualdade geral na tributação, imprescindível em uma sociedade justa, surge como resultado da ponderação entre a capacidade contributiva individual e o princípio da solidariedade, como ressaltou MARCO AURÉLIO GRECO ${ }^{119}$ :

Desta ótica, assume relevância a disposição contida no seu artigo $3^{\circ}$, I, que, ao prever os objetivos gerais de todo o País, consagra a noção de que a liberdade tem como contraponto a solidariedade, para que, da composição de ambas, surja como resultante uma sociedade justa. Isto significa que a própria igualdade geral e a capacidade contributiva no campo tributário devem ser vistas nesse contexto, ambas antes da

\footnotetext{
${ }^{116}$ PAOLA, Leonardo Sperb de. Presunções e ficções no direito tributário. Belo Horizonte: Del Rey, 1997, p. 142-143.

117 PAOLA, Leonardo Sperb de. Presunções e ficções no direito tributário. Belo Horizonte: Del Rey, 1997, p. 143-144.

${ }_{118}$ PAOLA, Leonardo Sperb de. Presunções e ficções no direito tributário. Belo Horizonte: Del Rey, 1997, p. 145.

${ }^{119}$ GRECO, Marco Aurelio. Planejamento fiscal e interpretação da lei tributária. São Paulo: Dialética, 1998, p. 147.
} 
igualdade tributária. Isto significa que a igualdade geral e a capacidade contributiva estão informadas pelo princípio da solidariedade social; e as próprias liberdades individuais não são absolutas, encontrando seu temperamento, também, na solidariedade social.

Vale repetirmos as palavras de SOUTO MAIOR: “O estatuto tributário é não só do contribuinte. É do fisco e contribuinte numa relação isonômica. Ao fisco o que é do fisco, mas só que é dele. Ao contribuinte somente o que lhe pertence". ${ }^{120}$

Não há como negar: sem a praticabilidade não se consegue uma tributação generalizada e, por conseguinte, uma efetividade do princípio da igualdade, mas, ao desconsiderar as particularidades do caso concreto, ou em outras palavras, não considerar as desigualdades de cada caso, a praticabilidade inevitavelmente fere a isonomia ou a igualdade individual. ${ }^{121}$

Não é outra a opinião de CASALTA NABAIS que ao expor o tema, aduz:

Por isso, o relevo ou mesmo o primado que o princípio técnico da praticabilidade deve assumir nos sectores jurídicos dominados pela fenomologia da massificação, como é paradigmaticamente o do direito dos impostos, é ainda, ao fim e ao cabo, um requisito dos próprios princípios materiais, sobretudo do princípio da igualdade, que, deste modo, se tem de contentar ou autolimitar para poder ser exequiível e praticável ${ }^{122}$.

\section{Corroborando esta conclusão, REgina HelEna Costa expôs o seguinte ponto de}

vista:

A nosso ver, o princípio da praticabilidade promove atenuações na diretriz maior da isonomia e, por conseqüência, em seu desdobramento - a capacidade contributiva-, com vistas a possibilitar, em concreto, a realização desses valores. Imbricam-se de tal modo essas noções, que não poderão ser dissociadas das considerações sobre a observância da isonomia no plano tributário as exigências técnicas da praticabilidade. Noutro dizer, a observância da capacidade contributiva é atenuada à vista do atingimento de outros fins, quais sejam, a viabilidade da aplicação em massa das leis tributárias e a eficiência da arrecadação. ${ }^{123}$

O paradoxo de que a igualdade será atendida não por serem consideradas todas as particularidades dos contribuintes, tratando cada caso de forma desigual, na medida de sua

\footnotetext{
${ }^{120}$ BORGES, Souto Maior. Princípio da Segurança Jurídica na Criação e Aplicação do Tributo. Revista de Direito Tributário, n. 63. São Paulo: Malheiros, 1993, p. 209.

121 "Do ponto de vista individual, o método de simplificação da execução das leis, que se discute, leva à tributação pela média, tendo-se em conta o que se considera normal ou padrão e desconsiderando-se as particularidades do caso concreto. Resulta desse processo uma ofensa à igualdade individual. Como lembra Schiffbauer, se o legislador tratou o factualmente desigual de modo desigual, de acordo com sua peculiaridade, a administração converte em igualdade aquilo que é desigualdade, desprezando as características individuais, juridicamente relevantes". DERZI, MisABEL DE ABREU MACHADO. Direito tributário, direito penal e tipo, 2. ed. São Paulo: Revista dos Tribunais, 2008, p. 343.

122 CABAIS, José Casalta. O Dever Fundamental de Pagar Impostos - Contributo para a compreensão constitucional do estado fiscal contemporâneo. 3. ed. Coimbra: Almedina, 2012, p. 620-621.

${ }^{123}$ COSTA, Regina Helena. Praticabilidade e justiça tributária - Exequibilidade de Lei Tributária e Direitos do Contribuinte, São Paulo: Malheiros, 2007, p. 124.
} 
desigualdade, e sim pela desconsideração destas particularidades, tratando-os com base em qualidades presentes na maioria dos casos, decorre do conflito existente entre as duas concepções de igualdade: igualdade particular e igualdade geral ou generalista.

A concepção generalista de igualdade propõe a desconsideração de elementos particulares em favor da avaliação das propriedades existentes na maioria dos casos. Isso é feito com a finalidade de alcançar uma solução previsível, eficiente e geralmente equânime na solução de conflitos sociais. A concepção particularista de igualdade sugere a consideração de elementos particulares mediante o afastamento do padrão legal. Isso é realizado com o propósito de atingir uma decisão justa e individualizada na solução de conflitos sociais. ${ }^{124}$

Pela concepção de igualdade particularista, a desconsideração de particularidades pelo uso das padronizações, pode provocar injustiças, principalmente se a particularidade relevada for avaliada como importante no momento da aplicação da lei. ${ }^{125}$

Por outro turno, na concepção de igualdade generalista, se as leis não forem expedidas como regras gerais, fixando-se previamente as diferenças a serem consideradas, gerariam imprevisibilidade e abandonariam à discricionariedade do aplicador, quais diferenças seriam relevantes na aplicação, o que consequentemente implicaria em um alto grau de arbitrariedade que não seria tolerado pelo princípio da igualdade. A lei deve ser aplicada a todos de forma isonômica e, neste sentido, visando reduzir o potencial de arbitrariedade que são criadas as padronizações.

A solução proposta por HUMBERTo ÁviLA é ponderar tanto o valor da igualdade individual, como o valor da igualdade geral, adotando um modelo moderado de igualdade particular procedimentalizada, que irá sempre que possível tratar os contribuintes de acordo com sua capacidade contributiva considerada em cada caso, mas quando isso não se realizar, por ser impossível ou extremamente onerosa a fiscalização, prevalecerá a generalização, sem abandono da igualdade individual que servirá como contraponto para a generalização. ${ }^{126}$

Segundo o autor anteriormente citado, a nossa Constituição deu preferência ao tratamento particularizado por: (i)estabelecer o dever de obediência à capacidade contributiva, conforme, princípio geral esculpido no art. $145, \S 1^{\circ}$.; (ii) mantê-lo como contraponto, mesmo

\footnotetext{
124 ÁVILA, Humberto. Teoria da Igualdade Tributária. 2a . edição. São Paulo: Malheiros, 2009, p. 84.

125 O exemplo esclarece: "A legislação do imposto sobre a renda permite a dedução de um montante máximo a título de gastos com a saúde e educação tanto do próprio contribuinte quanto de cada dependente seu. Esse limite é estabelecido a partir de gastos médios dos contribuintes e de seus dependentes com despesas básicas. No entanto, pode suceder que determinado contribuinte, por ter problemas psicológicos ou por ter um filho portador de determinada síndrome, revel uma situação particular que evidencie, para ele, nesse contexto, a insuficiência dos limites legais gerais. Seria uma experiência do contribuinte, não prevista pelo legislador, que desvelaria uma incompatibilidade entre aquilo que a lei buscava para todos os casos (permitir a dedução dos gastos essenciais com saúde e educação e com dependentes) e aquilo que a sua hipótese permitiu alcançar naquele caso (não permitiu a dedução dos gastos essenciais com saúde e educação com dependentes)". ÁVILA, Humberto. Teoria da Igualdade Tributária. $2^{\mathrm{a}}$. edição. São Paulo: Malheiros, 2009, p. 79.

${ }^{126}$ ÁVILA, Humberto. Teoria da Igualdade Tributária. 2a . edição. São Paulo: Malheiros, 2009, p. 85.
} 
quando a cobrança do tributo é feita com base presumida ${ }^{127}$; e (iii) por exigir sua observância, pelos entes federados, na instituição das espécies tributárias. ${ }^{128}$

A consideração das particularidades pressupõe a observação de suas capacidades contributivas objetiva e subjetiva, que serão relevadas nos casos de impossibilidade fiscalizadora pela administração, uma vez que "sua consideração causaria - pela falta de previsão, controle, coordenação, modicidade e conhecimento - mais generalização do que individualização". ${ }^{129}$

A generalização, obtida pelo uso das padronizações ou tipificações, considera os elementos frequentes, médios que estão presentes na grande maioria dos casos, não representa o abandono da capacidade contributiva objetiva, pelo contrário, "é o instrumento para sua própria concretização na maioria dos casos". ${ }^{130}$

Firmamos a seguinte conclusão: com as padronizações o legislador consegue tributar de forma isonômica um número muito maior de contribuintes, do que conseguiria se fosse levada em conta a verificação individual da capacidade contributiva e, procedendo assim, ao contrário do que se pode inicialmente conceber, concretiza o princípio da igualdade.

Se concretizar o primado da isonomia é realizar justiça, passemos à análise de sua relação com a praticabilidade.

\subsection{Justiça fiscal}

Justiça é o conceito mais fundamental do Direito, mas também é o mais abstrato. ${ }^{131}$ No Estado de Direito tudo deve ocorrer com justiça, sendo que essa exigência maior não pode ser afastada por qualquer outra exigência. ${ }^{132}$

\footnotetext{
${ }^{127} \mathrm{Na}$ substituição tributária, inserida pela Emenda Constitucional n. 3/1993, a "lei poderá atribuir a sujeito passivo de obrigação tributária a condição de responsável pelo pagamento de imposto ou contribuição, cujo fato gerador deva ocorrer posteriormente, assegurada a imediata e preferencial restituição da quantia paga, caso não se realize o fato gerador presumido", mostra que "a Constituição não autoriza o legislador a adotar qualquer base de cálculo para a obrigação tributária com substituição, mas apenas aquela cuja grandeza corresponda a fato que deve ocorrer posteriormente. Essa manutenção da vinculação do presumido com o real preserva a capacidade contributiva objetiva como princípio geral da atividade tributária. Não por outro motivo, a Constituição faz referência à não-realização do fato gerador presumido, o que pressupõe o cotejo entre ele e o real". Ibidem, p. 86-87.

128 ÁVILA, Humberto. Teoria da Igualdade Tributária. 2a. edição. São Paulo: Malheiros, 2009, p. 85-88.

129 ÁVILA, Humberto. Teoria da Igualdade Tributária. 2a . edição. São Paulo: Malheiros, 2009, p. 88.

${ }^{130}$ Ibidem, p. 89.

131 TIPKE, Klaus; YAMASHITA, Douglas. Justiça Fiscal e Princípio da Capacidade Contributiva, p 19.

132 TIPKE, Klaus. Moral Tributária do Estado e dos Contribuintes. Tradução: Luiz Dória Furquim. Porto Alegre: Sergio Antonio Fabris, 2012, p. 13.
} 
Nossa Constituição no art. $3^{\circ}$, I declara-se por "uma sociedade livre, justa e solidária", mas a justiça, principalmente quando direitos e obrigações são repartidos entre os cidadãos (justiça distributiva), pressupõe princípios. "Repartição sem princípios é repartição arbitrária. Isso é pacífico, tanto na filosofia moral como na filosofia do direito. A orientação por princípios cuida da generalidade e conseqüência". ${ }^{133}$

O princípio a ser adotado para a realização da justiça vai depender do ramo do direito, ou seja, um mesmo princípio não é adequado a todos os campos, devendo ser adequado à realidade, o que se denomina na Alemanha justiça adequada à matéria. ${ }^{134}$

Há justiça quando há garantia da igualdade perante a lei e no direito tributário o princípio amplamente reconhecido é da igualdade na distribuição da carga tributária de acordo com a capacidade contributiva.

A praticabilidade ao implicar nas simplificações para possibilitar a aplicação em massa das leis tributárias, desconsiderando diferenças nos casos concretos, seria incompatível com a justiça tributária, ao tratar igualmente casos desiguais, violando o princípio da igualdade e da capacidade contributiva?

MISABEL DERZI ${ }^{135}$ entende ser a simplificação da execução das leis, por tributar pela média, desconsiderando-se as particularidades de cada caso, uma ofensa à igualdade individual: "Praticabilidade e justiça fiscal são princípios incompatíveis", embora admita que a praticabilidade sirva à uniformidade geral.

Abandonar as diferenças individuais, pela praticabilidade, traz inevitavelmente como consequência que "os princípios da igualdade, no sentido de justiça individual, e da capacidade contributiva são abrandados (e frequentemente violados)" ${ }^{136}$

De opinião totalmente contrária, JOSÉ CASALTA NABAIS ${ }^{137}$ desenvolve o raciocínio de que a massificação das relações jurídico-fiscais ao exigir dos milhares de contribuintes, além de a obrigação principal do recolhimento do tributo, uma quantidade cada vez maior e mais complexa de obrigações acessórias, conduz "a uma tal hipertrofia, complexização e incoerência dos preceitos de direito fiscal, que torna de todo inviável a sua aplicação e execução em termos

\footnotetext{
133 TIPKE, Klaus. Moral Tributária do Estado e dos Contribuintes. Tradução: Luiz Dória Furquim. Porto Alegre: Sergio Antonio Fabris, 2012, p. 14-15.

134 TIPKE, Klaus; YAMASHITA, Douglas. Justiça Fiscal e Princípio da Capacidade Contributiva, p. 21.

135 DERZI, Misabel de Abreu Machado. Direito tributário, direito penal e tipo, 2. ed. São Paulo: Revista dos Tribunais, 2008 , p. 355.

136 DERZI, Misabel de Abreu Machado. Praticidade. ICMS. Substituição tributária progressiva, "para frente". In:__ (Coord.). Construindo o Direito Tributário na Constituição. Belo Horizonte: Del Rey, 2004. p. 177.

${ }_{137}$ NABAIS, José Casalta. O Dever Fundamental de Pagar Imposto - Contributo para a compreensão constitucional do estado fiscal contemporâneo. 3. ed. Coimbra: Almedina, 2012. p. 620.
} 
minimamente respeitadores dos princípios de justiça, mormente do princípio da igualdade fiscal, em nome dos quais justamente essa massificação se estabeleceu".

Utilizando-se do brocardo summum jus, summa injuria (o ótimo é inimigo do bom), o jurista lusitano aduz que a busca por uma tributação excessivamente preocupada com a busca da capacidade efetiva dos contribuintes e, por conseguinte, com uma busca maximalista da justiça fiscal, pode conduzir, pela impossibilidade de sua aplicação e execução, justamente para o resultado oposto.

Quanto mais o legislador tenta pormenorizar a norma tributária, mais lacunas acabam sendo geradas, “ou seja, as especificações excessivas, porque se enredam na riqueza dos pormenores, perdem o plano de que partiram, acabando, ao invés, por conduzir a maior indeterminação". ${ }^{138}$

Normas tributárias com muitas lacunas, somada a impossibilidade prática da fiscalização e controle, conduzirão certamente a uma "fraude fiscal violadora da mais elementar justiça”. ${ }^{139}$

Neste cenário de normas cada vez mais complexas e uma administração cada vez mais carente de recursos, os contribuintes de grande capacidade contributiva e com grande complexidade em suas transações econômicas, tornam-se infiscalizáveis e insancionáveis, em razão da exorbitante mobilização de recursos humanos e materiais que seriam exigidos da administração.

Como consequência somente os pequenos e médios contribuintes seriam fiscalizados de forma a se obter o valor real do tributo em face de sua real capacidade contributiva, o que representa um afastamento cada vez maior na busca da justiça fiscal.

Por essa razão, concordamos com JosÉ CASALTA NABAIS ${ }^{140}$ quando afirma que: “a justiça fiscal e a praticabilidade não são incompatíveis, constituindo-se esta uma das actuais vias - e, por certo, não das menos importantes - de realização daquela".

O legislador ao considerar as particularidades concretas de situação real, funda-se na justiça individual, mas quando opta por desconsiderar o caso que realmente ocorre em favor daquele que normalmente ocorre, em razão da simplificação, estará baseando-se na justiça geral. $^{141}$

\footnotetext{
${ }^{138}$ NABAIS, José Casalta. O Dever Fundamental de Pagar Imposto - Contributo para a compreensão constitucional do estado fiscal contemporâneo. 3. ed. Coimbra: Almedina, 2012. p. 377.

${ }^{139}$ NABAIS, José Casalta. O Dever Fundamental de Pagar Imposto - Contributo para a compreensão constitucional do estado fiscal contemporâneo. 3. ed. Coimbra: Almedina, 2012. p. 620.

${ }^{140}$ Ibidem, p. 621.

${ }^{141}$ ÁVILA, Humberto. Imposto sobre a circulação de mercadorias: ICMS; substituição tributária; base de cálculo; pauta fiscal; preço máximo ao consumidor; diferença constante entre o preço usualmente praticado e o preço constante da pauta ou o preço
} 
HUMBERTO ÁvILA revela que segundo a concepção particularista de justiça: “justa é a decisão que leva em conta as particularidades dos destinatários; e equânime é a decisão que considera todas as diferenças existentes entre os seus destinatários" ${ }^{142} \mathrm{e}$, para a concepção generalista de justiça: “justa é a decisão que leva em conta as características médias dos destinatários; e equânime é a decisão que considera diferenças selecionadas pelo legislador como relevantes, desprezando outras distinções". ${ }^{143}$

As leis ao tentarem buscar a efetiva capacidade contributiva real, tornam-se tão complicadas que não poderão ser seguidas nem pelos contribuintes nem pela administração, ou seja, não serão igualmente aplicadas, de tal sorte que a pretendida justiça individual com igualdade da carga tributária, não poderá ser alcançada, a não ser pela utilização de normas simplificadoras com o propósito de garantir a igualdade da carga na aplicação em massa das normas impositivas de tributos.

Ao simplificar, o que o legislador busca é a efetivação da igualdade geral mediante consideração de elementos que reflitam concretamente a média dos casos reais, não se afastando do princípio da igualdade, pois ao proceder desta maneira certamente irá garantir mais igualdade do que um sistema deficiente de verificação individual da capacidade do contribuinte.

Em suma, "a simplificação e a economia de gastos são causas eficientes e consequências desejadas, mas o fim é a realização eficiente da igualdade geral". ${ }^{144}$

RICARDO LOBO TORRES pondera que a clareza ao lado da ponderação, razoabilidade, igualdade e transparência são princípios de legitimação do poder de tributar. $\mathrm{O}$ professor doutrina que a clareza e a simplicidade estão intimamente ligadas aos princípios da justiça tributária e segurança jurídica. "Sem clareza e simplicidade não se obtém a tributação segundo a capacidade contributiva, o custo/benefício e a solidariedade. A legislação obscura e caótica leva, necessariamente, à injustiça fiscal”. ${ }^{145}$

Das exposições doutrinárias apresentadas, podemos inferir que a praticabilidade além de compatível com a justiça fiscal, é uma dos principais meios de sua realização, tanto pela possibilidade de aplicação e execução da lei tributária aos milhares de contribuintes de

\footnotetext{
máximo ao consumidor sugerido pelo fabricante; exame de constitucionalidade. Revista Dialética de Direito Tributário, n.123. São Paulo: Dialética, 2005, p. 124.

142 ÁVILA, Humberto. Teoria da Igualdade Tributária. 2ª edição. São Paulo: Malheiros, 2009 , p. 81.

143 Ibidem, p. 82.

144 ÁVILA, Humberto. Imposto sobre a circulação de mercadorias: ICMS; substituição tributária; base de cálculo; pauta fiscal; preço máximo ao consumidor; diferença constante entre o preço usualmente praticado e o preço constante da pauta ou o preço máximo ao consumidor sugerido pelo fabricante; exame de constitucionalidade. Revista Dialética de Direito Tributário, n.123. São Paulo: Dialética, 2005, p. 124.

145 TORRES, Ricardo Lobo. Liberdade, Consentimento e Princípios de Legitimação do Direito Tributário. Revista Internacional de Direito Tributário, v. 5. Minas Gerais: Del Rey, janeiro/julho de 2006, p. 230-231.
} 
forma isonômica, quanto pelo fato de somente a lei clara e simples ter aptidão para conduzir à afirmação da segurança jurídica e promover a justiça tributária. 


\subsection{Discriminação constitucional de competências}

A república federativa do Brasil é composta pela União, Estados e Municípios e Distrito Federal, todos no mesmo plano hierárquico e com autonomia ${ }^{146}$, conforme prescrição dos arts. $1^{\circ}$. e 18 da Carta Constitucional. ${ }^{147}$

Sem receitas próprias não há que se falar em autonomia, como afirma José MAURÍCIO CONTI:

As repartições de receitas consubstanciam um ponto crucial na organização dos Estados sob a forma federativa, pois assegura a independência financeira das entidades que compõem a federação, verdadeiro alicerce da autonomia destas entidades $^{148}$.

A forma de garantir a repartição de receitas e consequentemente a autonomia das pessoas políticas que compõem a federação concretizou-se com uma rígida discriminação constitucional de competências.

Essa rigidez representa um relevante limite à atividade legislativa na instituição de tributos e como tal deve também ser observado na criação de normas simplificadoras que definem padronizações na tributação.

Esse dever de obediência à discriminação constitucional de competências deriva do princípio federativo ${ }^{149}$, pois "é inconcebível pensar em Federação sem repartição de

\footnotetext{
146 A autonomia dos municípios já foi questionada, por boa parte da doutrina, mas hoje, essa autonomia apresenta-se inquestionável. Na Constituição encontramos em várias prescrições confirmatórias da existente autonomia dos municípios, como por exemplo: no art. $13, \S 2^{\circ}$ que os autoriza a ter símbolos próprios; no art. 18 caput indicando expressamente que União, Estados, Distrito Federal e Municípios são todos autônomos entre si; encontramos no art. $18, \S 4^{\circ}$ a necessidade de consulta prévia à população municipal nos casos de criação, incorporação, fusão ou desmembramento de Municípios etc. Afirmando a autonomia e competência municipal para dispor sobre matéria tributária, o art. 30, III, prescreve competir aos Municípios a instituição e arrecadação dos tributos de sua competência, bem como aplicação de suas rendas. Sua competência é assegurada ao equiparar os Municípios aos outros entes no art. 145, caput, e ao lhes assegurar a imunidade recíproca, inviabilizando aos outras pessoas políticas de onerarem o patrimônio municipal com tributos. CARVALHO, Paulo de Barros. Direito Tributário Linguagem e Método. 3. ed. São Paulo: Noeses, 2009, p. 292.

147 Art. 1. CF/88: A República Federativa do Brasil, formada pela união indissolúvel dos Estados e Municípios e do Distrito Federal, constitui-se em Estado Democrático de Direito e tem como fundamentos [...]; Art. 18 CF/88: A organização políticoadministrativa da República Federativa do Brasil compreende a União, os Estados, o Distrito Federal e os Municípios, todos autônomos, nos termos da Constituição

${ }^{148}$ CONTI, José Maurício. Federalismo fiscal e fundos de participação. São Paulo: Juarez de Oliveira, 2001, p. 35.

${ }^{149}$ Pensando de forma diferente, Luís Eduardo Schoueri não entende a discriminação de competências como um requisito de um sistema federal. A autonomia financeira que o federalismo exige implica discriminação de rendas, o que não se confunde com a discriminação de competências. As diretrizes que levaram o constituinte a adotar a repartição de competências foram: "Para os tributos vinculados, justificados pelo sinalagma, a competência se resolve a partir do conceito de competência anexa: quem tem a atribuição para a atividade estatal terá, igualmente, competência tributária; Para os tributos não vinculados, justificados pela capacidade contributiva, o próprio constituinte trata de atribuir as competências tributárias, tomando o cuidado de afastar a cumulação de competências". SCHOUERI, Luís Eduardo. Direito Tributário. São Paulo: Saraiva, 2011, p. 240241.
} 
competências. O princípio federativo reclama, inexoravelmente, que competências sejam distribuídas, em especial as competências legislativas". ${ }^{150}$

A discriminação rígida de competências "tem como pedra básica a competência privativa, mola mestre do sistema, o qual repele a bitributação e evita a promiscuidade entre tributos distintos". ${ }^{151}$

A característica da privatividade das normas constitucionais que discriminam as competências tributárias encerra um duplo comando: “1) habilitam a pessoa política contemplada - e somente ela -a criar, querendo, um dado tributo; e 2) proíbem as demais de virem a instituí-lo". ${ }^{152}$

$\mathrm{Na}$ discriminação das competências, nossa Carta Maior foi exaustiva e extremamente detalhista ao apontar as hipóteses de incidência, os sujeitos ativo e passivo, base de cálculo e alíquota de cada uma das exações que poderão ser instituídas pela União, Estados, Municípios e Distrito Federal.

Na hipótese de incidência o constituinte determinou de forma rígida a riqueza a ser tributada e na base de cálculo a medida de sua materialidade, de forma a garantir: a segurança jurídica do contribuinte com a previsibilidade de qual manifestação de riqueza será tributado; e evitar que uma mesma riqueza seja tributada por entes distintos, isto é, afastar a bitributação.

A análise do binômio hipótese de incidência e base de cálculo torna-se, assim, imprescindível no estudo da discriminação de competências tributárias, como afirma RoQUE CARRAZZA:

O tipo tributário é revelado, no Brasil, após a análise conjunta da hipótese de incidência e da base de cálculo da exação. Assim, a Lei das Leis, ao discriminar as competências tributárias das várias pessoas políticas, estabeleceu igualmente, as bases de cálculo 'in abstracto' possíveis dos vários tributos federais, estaduais, municipais e distritais. Melhor esclarecendo, se o tributo é sobre a renda, sua base de cálculo deverá, necessariamente, levar em conta uma medida da renda ( $v . g$., a renda líquida); se o tributo é sobre a propriedade, sua base de cálculo deverá, necessariamente, levar em conta uma medida da propriedade ( $v . g$., o valor venal da propriedade); se o tributo

\footnotetext{
${ }^{150}$ BARRETO, Aires Fernandino. Curso de Direito Tributário Municipal. São Paulo: Saraiva, 2009, p. 10. No mesmo sentido: "No Brasil, a questão da discriminação da competência tributária é manifestação do próprio federalismo, por configurar partilha, descentralização do poder de instituir e regular tributos". DERZI, Misabel de Abreu Machado. Direito tributário, direito penal e tipo, 2. ed. São Paulo: Revista dos Tribunais, 2008, p. 137.

${ }^{151}$ DERZI, Misabel de Abreu Machado. Direito tributário, direito penal e tipo, 2. ed. São Paulo: Revista dos Tribunais, 2008, p. 137. A autora completa o raciocínio afirmando:" Conceitos como bitributação, invasão de competência, bis in idem, identidade ou diversidade entre espécies tributárias necessários ao funcionamento harmônico e aplicação das normas constitucionais não se aperfeiçoam por meio das relações comparativas do 'mais ou menos' ou 'tanto mais...quanto menos' inerentes ao pensamento tipológico. Muito mais ajustam-se às excludentes 'ou...ou' e às características irrenunciáveis e rígidas dos conceitos determinados". Ibidem, p. 137.

152 CARRAZZA, Roque Antonio. Curso de Direito Constitucional Tributário. 22. Ed. São Paulo: Malheiros, 2006, p. 487. Neste sentido: "As competências tributárias são inalargáveis. Assim, de um lado, a entidade político-constitucional pode exercer a competência recebida em toda a sua plenitude; de outro, porém, não pode ampliar, alargar, dilatar a competência recebida. A pessoa política deve conter-se nos contornos traçados pela Constituição. Qualquer excesso, por ínfimo que seja, implica invalidade da norma editada”. BARRETO, Aires Fernandino. Curso de Direito Tributário Municipal. São Paulo: Saraiva, 2009, p. 11.
} 
é sobre serviços, sua base de cálculo deverá, necessariamente, levar em conta uma medida dos serviços ( $v . g$., o valor dos serviços prestados). Os exemplos poderiam ser multiplicados, até porque a base de cálculo e a hipótese de incidência de todo e qualquer tributo devem guardam uma relação de inerência. Em suma, a base de cálculo há de ser, em qualquer tributo (imposto, taxa ou contribuição de melhoria), uma medida da materialidade da hipótese de incidência tributária ${ }^{153}$.

Essa relação de inerência entre a base de cálculo e a hipótese de incidência não passou despercebida por LUís EDUARDO SCHOUERI, que vê na proibição constitucional para criação de novos impostos com o emprego da base de cálculo própria dos impostos já discriminados na Carta Magna, a confirmação pelo constituinte de uma relação de unicidade, "que impede que uma base de cálculo própria de um imposto já previsto seja empregada para quantificar outro fato gerador". ${ }^{154}$

Podemos concluir, juntamente com Aires BARRETO, que: “O arsenal de opções de que dispõe o legislador ordinário para a escolha da base de cálculo, conquanto vasto, não é ilimitado. Cumpre-lhe erigir critério dimensível consentâneo com o arquétipo desenhado pela Excelsa Lei”. ${ }^{155}$ Pela rígida discriminação de competências imposta pelo federalismo, "as várias possibilidades de que dispõe o legislador ordinário para adoção da base de cálculo já se contêm na Constituição". ${ }^{156}$

A partir destas considerações doutrinárias, pode-se afirmar que as simplificações tributárias, traduzidas nas padronizações, pelo uso de presunções e ficções, mormente da base de cálculo, não poderão desvinculá-la a ponto de não mais representar uma medida da materialidade da hipótese de incidência, sob pena, de assim o fazendo, serem consideradas inconstitucionais, por não respeitar a discriminação de competências, pondo em risco o pacto federativo.

\footnotetext{
${ }^{153}$ CARRAZZA, Roque Antonio. Curso de Direito Constitucional Tributário. 22. Ed. São Paulo: Malheiros, 2006 , p. 483. Neste sentido Paulo de Barros Carvalho afirma que esse binômio, por ele denominado de princípio de dualidade compositiva, constitui-se em verdadeira "diretriz constitucional, firmada no momento em que o legislador realizava o delicado trabalho de montar a rígida discriminação de competências tributárias, preocupado em preservar os princípios da Federação e da autonomia dos Municípios". CARVALHO, Paulo de Barros. Direito Tributário Linguagem e Método. 3. ed. São Paulo: Noeses, 2009 , p. 398.

${ }^{154}$ SCHOUERI, Luís Eduardo. Discriminação de competências e competência residual. In: SCHOUERI, Luís Eduardo; ZILVETI, Fernando Aurélio (Coords.). Direito Tributário: estudos em homenagem a Brandão Machado. São Paulo: Dialética, 1998, p. 99-100.

${ }^{155}$ BARRETO, Aires Fernandino. Curso de Direito Tributário Municipal. São Paulo: Saraiva, 2009, p. 155.

${ }^{156}$ Ibidem, p. 155.
} 


\subsection{Proporcionalidade}

Já destacamos anteriormente que as normas simplificadoras não têm a finalidade fiscal preponderante de obtenção de receitas, mas buscam precipuamente facilitar a arrecadação e fiscalização da administração tributária, ou seja, como finalidade extrafiscal buscam a simplificação da gestão tributária como um todo.

Em razão da impossibilidade prática de verificar a situação individual de cada contribuinte com o intuito de apurar sua capacidade contributiva efetiva, o legislador simplifica, com o uso de ficções e presunções, criando casos padrões que servem como modelo único para uma infinidade de casos.

A capacidade contributiva serve como medida de diferenciação entre os contribuintes, nos tributos que se destinam a atingir uma finalidade fiscal, mas, quando os tributos tenham outra finalidade que não seja o fim preponderante de obter receitas, isto é finalidade extrafiscal, a medida de comparação "deverá corresponder a um elemento ou propriedade que mantenha relação de pertinência, fundada e conjugada, com a finalidade eleita". ${ }^{157}$

Esse afastamento em maior ou menor medida da capacidade contributa e por conseguinte do princípio da igualdade exige a submissão da tributação a outro tipo de controle de aplicação da própria igualdade: "o controle de proporcionalidade"158

O postulado ${ }^{159}$ da proporcionalidade que decorre dos princípios do Estado Democrático de Direito (art. $1^{\circ}$ da CF/88) e do devido processo legal (art., $5^{\circ}, \mathrm{LIV}$, da CF/88), além de as orientações gerais do Preâmbulo, tem sido utilizado de forma reiterada pelo Supremo Tribunal Federal, como forma de harmonizar valores, principalmente no conflito entre princípios $^{160}$, com base na relação entre meio e fim.

\footnotetext{
157 ÁVILA, Humberto. Teoria da Igualdade Tributária. 2a ${ }^{\text {a }}$ edição. São Paulo: Malheiros, 2009, p. 161.0 autor cita como exemplos de finalidade extrafiscais: "A manutenção do Estado Federativo (art. 18), a garantia da segurança pública (art. 144), a preservação da ordem econômica (arts. 170 e ss.), a implementação da política urbana (arts. 182 e 183), a garantia da função social da propriedade (arts. 184 a 191), preservação da ordem social (arts. 193 a 231), a evolução da ciência e da tecnologia (arts. 218 a 224), a proteção do meio ambiente (art. 225) e da família (arts. 231 e 232), a fiscalização e o controle sobre o comércio exterior (art. 237), entre tantos outros fins direta ou indiretamente previstos no ordenamento constitucional, e que irão permitir a verificação d compatibilidade da medida de comparação legalmente escolhida". Ibidem, p. 161.

158 ÁVILA, Humberto. Teoria da Igualdade Tributária. 2a . edição. São Paulo: Malheiros, 2009, p. 162.

159 "Não consiste numa condição no sentido de que, sem ela, a aplicação do direito seria impossível. Consiste numa condição normativa, isto é, instituída pelo próprio direito para a sua devida aplicação. Sem obediência ao dever de proporcionalidade não há a devida realização integral dos bens juridicamente resguardados. É dizer: ele traduz um postulado normativo aplicativo como aqui si afirma". ÁVILA, Humberto Bergmann. A distinção entre princípios e regras e a redefinição do dever de proporcionalidade. Revista de Direito Administrativo, Rio de Janeiro: Renovar, vol. 215, p. 169-170, 1999.

${ }^{160}$ HARET, Florence. Teoria e Prática das Presunções no Direito Tributário. São Paulo: Noeses, 2011, p. 609-610; ÁVILA, Humberto. A Teoria dos Princípios e o Direito Tributário. Revista Dialética de Direito Tributário, n.125. São Paulo: Dialética, 2006, p.48.
} 
O exame da proporcionalidade aplica-se sempre numa relação de causalidade entre meio e fim, isto é, "sempre que houver uma medida concreta destinada a realizar uma finalidade"161, envoltos por uma série de bens jurídicos resguardados por princípios constitucionais.

No exame da proporcionalidade deve-se verificar as possibilidades de determinada medida alcançar o fim desejado: (i) adequação, ou aptidão ou pertinência do meio utilizado para atingimento da fim desejado; (ii) necessidade, ou exigibilidade do meio ser o menos restritivo dentre os meios disponíveis para atingir o fim; e (iii) proporcionalidade em sentido estrito do meio escolhido, de forma que ele proporcione mais vantagens do que desvantagens. ${ }^{162}$

Cabe nesse nosso estudo o controle de proporcionalidade entre as os meios (padronizações) e o fim desejado (praticabilidade)?

Para responder essa questão, socorremo-nos novamente aos ensinamentos de HUMBERTO ÁvILA. ${ }^{163}$ Inicialmente cabe destacar que há fins internos e fins externos no direito. Nos fins internos não há uma relação meio-fim, que se confunde na própria pessoa ou situação objeto de comparação e diferenciação e portanto, não cabe o exame do postulado da proporcionalidade. ${ }^{164}$

Os fins externos são aqueles perquiridos pelo Estado ao proceder uma determinada medida, ou seja, neste caso é possível diferenciar o meio do fim, por se constituírem em uma relação causal de determinada medida como meio para atingir determinado fim. Como exemplos: "Os fins sociais e econômicos podem ser qualificados de fins externos, como o são

\footnotetext{
161 ÁVILA, Humberto. Proporcionalidade e Direito Tributário. Revista Direito Tributário Atual, n.25. São Paulo: Dialética, 2011, p. 87. "Com efeito, o postulado da proporcionalidade pressupõe a relação de causalidade entre o efeito de uma ação (meio) e a promoção de um estado de coisa (fim). Adotando-se o meio, promove-se o fim: o meio leva ao fim". ÁVILA, Humberto. Teoria dos princípios: da definição à aplicação dos princípios jurídicos. São Paulo: Malheiros, 2003, p. 102-103. 162 ÁVILA, Humberto. A Teoria dos Princípios e o Direito Tributário. Revista Dialética de Direito Tributário, n.125. São Paulo: Dialética, 2006, p.44. Assim a doutrina: "Primeiro, há casos em que é analisada a correlação entre dois bens jurídicos protegidos por princípios constitucionais, em função dos quais é preciso saber se a medida adotada é adequada para atingir o fim constitucionalmente instituído (relação meio x fim), se a medida é necessária enquanto não substituível por ou tro meio igualmente eficaz e menos restritivo do bem jurídico envolvido (relação meio x meio) e se a medida não está em relação de desproporção em relação ao fim a ser atingido (relação meio x fim). Nesse caso, devem ser analisados dois bens jurídicos protegidos por princípios constitucionais e a medida adotada para sua proteção (...). Trata-se de um exame abstrato dos bens jurídicos envolvidos (segurança, liberdade, vida etc.) especificamente em função da medida adotada”. ÁVILA, Humberto Bergmann. A distinção entre princípios e regras e a redefinição do dever de proporcionalidade. Revista de Direito Administrativo, Rio de Janeiro: Renovar, vol. 215, p. 163, 1999.

163 ÁVILA, Humberto. Proporcionalidade e Direito Tributário. Revista Direito Tributário Atual, n.25. São Paulo: Dialética, 2011, p. 88-89.

164 ÁVILA, Humberto. Proporcionalidade e Direito Tributário. Revista Direito Tributário Atual, n.25. São Paulo: Dialética, 2011, p. 88. "O decisivo é que os fins internos exigem determinadas situações, e devem realizar uma propriedade que seja relevante para determinado tratamento. Daí a razão pela qual se faz referência a medidas de justiça ou juízos de justiça: a capacidade contributiva é tanto medida, pois consiste em critério para a tributação justa, quanto fim, pois estabelece algo cuja existência fundamenta a própria realização da igualdade. A capacidade contributiva não causa a justiça da tributação; e o meio e o fim confundem-se em razão de não poderem ser concretamente discernidos. Como consequência disso, o exame de igualdade do ponto de vista de um fim interno e uma medida de justiça exigem tão somente um exame de correspondência".
} 
a praticabilidade administrativa, o planejamento econômico específico, a proteção ambiental" (grifo nosso). ${ }^{165}$

Quando há a finalidade externa nas normas jurídicas tributárias, a obediência ao dever de proporcionalidade admite seu caráter trifásico, conforme explica HUMBERTO ÁvILA ${ }^{166}$ :

\begin{abstract}
E isso ocorre porque há uma finalidade objetivamente determinável e estruturante da relação jurídica, em função da qual a relação meio-fim adquire consistência. Nessas hipóteses, em que as normas possuem eficácia formativa de comportamento (criadora de obrigações que afetam os direitos de liberdade) e não uma eficácia meramente impositiva (criadora de encargo tributário desvinculado), o fim serve como estruturador da relação, a tal ponto que o caráter trifásico do dever de proporcionalidade pode ser utilizado.
\end{abstract}

Da mesma forma, analisando o vínculo de causalidade entre meio e fim, FLORENCE HARET alerta que a mera facilitação na arrecadação pelo fisco não é causa suficiente para a utilização de presunções na expedição de normas de incidência tributária: "Ora, se por outras vias se pode atingir o mesmo objetivo, a presunção não deve prevalecer. Cabe ao legislador sempre escolher o meio menos gravoso para chegar ao fim jurídico desejado". ${ }^{167}$

O fim a ser buscado, quando do emprego de presunções, aponta a jurista, é o extrafiscal, enumerando entre outros exemplos os mecanismos: "redutores dos custos na aplicação da lei tributária; e "preservadores do interesse público - enquanto instrumento legal dirigido, quase que invariavelmente, ao objetivo de beneficiar a fazenda pública", os quais podemos traduzir como finalidades que se identificam com a praticabilidade. Destacamos a síntese de seu raciocínio: “Em outras palavras, é a condição jurídica que confere legitimidade ao emprego de presunções (meio) para criar, arrecadar e fiscalizar tributo (fim fiscal) em vista de outros fins que procuram resguardar o perfeito funcionamento do sistema tributário (fim extrafiscal). É esta finalidade última que confere consistência à atividade estritamente físcal do primeiro". ${ }^{168}$

Enfim, no implemento das padronizações como medidas para realização do fim específico da praticabilidade, caberá examinar se a medida do distanciamento da igualdade é

\footnotetext{
165 ÁVILA, Humberto. Proporcionalidade e Direito Tributário. Revista Direito Tributário Atual, n.25. São Paulo: Dialética, 2011, p. 89.

166 ÁVILA, Humberto. Proporcionalidade e Direito Tributário. Revista Direito Tributário Atual, n.25. São Paulo: Dialética, 2011, p. 101.

${ }^{167}$ HARET, Florence. Teoria e Prática das Presunções no Direito Tributário. São Paulo: Noeses, 2011, p. 612.

${ }^{168}$ HARET, Florence. Teoria e Prática das Presunções no Direito Tributário. São Paulo: Noeses, 2011, p. 612-613.
} 
proporcional e para tanto realizar exame da necessidade, adequação e proporcionalidade ${ }^{169} \mathrm{em}$ sentido estrito, caso contrário, a realização da igualdade estará comprometida.

\subsubsection{Necessidade}

Medida necessária é aquela, entre todas as disponíveis e igualmente aptas para atingir o fim colimado, que se apresente como a menos restritiva dos direitos fundamentais afetados.

Pode-se então afirmar que nas normas gerais para tributação por meio de padrões legais, "o meio necessário é aquele mais suave ou menos gravoso, relativamente à restrição aos direitos fundamentais colaterais, para a média dos casos". ${ }^{170}$

Como a Constituição privilegiou que fosse considerado o modelo individualista de igualdade, a padronização, que considera o modelo generalista de igualdade, só deve ser usada excepcionalmente, no denominado estado de necessidade da administração.

Nessa situação, que já discorremos anteriormente, a administração em razão da impossibilidade de recursos humanos e financeiros para apuração da real capacidade contributiva de cada contribuinte individualmente considerado pode adotar uma tributação com bases presuntivas. "A padronização deve, pois ser uma necessidade prática da administração (eine praktische Bedürfnisder Verwaltung)". ${ }^{171}$

\footnotetext{
169 Herrera Molina citado por Regina Helena Costa resumiu o exame da necessidade, adequação e proporcionalidade: "Necessidade - o controle administrativo não seria possível com outra medida que não ofenderia a capacidade econômica. Nesse caso, o controle do critério de necessidade supõe uma certa "ponderação" de bens, uma vez que habitualmente será possível outra solução mais respeitosa com a contribuição segundo a capacidade econômica que originaria um maior custo administrativo. Portanto, conclui que a "necessidade" com critério autônomo de controle resulta aqui, dificilmente aplicável. À vista de tal ponderação de bens jurídicos, a medida de simplificação somente será admissível se concorrerem as seguintes condições: (i) que na maioria dos casos a tributação individual se aproxime mais da capacidade econômica do que aconteceria se não existisse o mecanismo simplificador; (ii) que em nenhuma hipótese previsível pelo legislador se produza uma carga fiscal radicalmente distinta da que corresponderia com fundamento na capacidade econômica; (iii) que a medida de simplificação não possa ser suprimida sem um aumento desproporcionado dos custos de gestão, que repercutiria em prejuízo de todos os contribuintes". COSTA, Regina Helena. Praticabilidade e justiça tributária - Exequibilidade de Lei Tributária e Direitos do Contribuinte, São Paulo: Malheiros, 2007, p. 172.

170 ÁVILA, Humberto. Proporcionalidade e Direito Tributário. Revista Direito Tributário Atual, n.25. São Paulo: Dialética, 2011, p. 98.

171 ÁVILA, Humberto. Teoria da Igualdade Tributária. 2a . edição. São Paulo: Malheiros, 2009, p. 95.
} 


\subsubsection{Adequação}

Ao se buscar a adequação, exigir-se-á do administrador a utilização de um "meio cuja eficácia (e não o meio, ele próprio) possa contribuir para a promoção gradual do fim".

Dizer que um meio é o mais adequado para atingir uma determinada finalidade vai depender da análise dos meios disponíveis e do fim que se quer promover, em que aspecto vai ser analisada a adequação e por fim como será a intensidade do controle das decisões adotadas pela administração. ${ }^{172}$

Respondendo essas questões, HuMBERTo ÁvILA aponta que: (i) “A Administração e o legislador têm o dever de escolher um meio que simplesmente promova o fim"173; (ii) "nas hipóteses em que o Poder Público está atuando para uma generalidade de casos - por exemplo, quando edita atos normativos-, a medida será adequada se, abstrata e geralmente, servir de instrumento para a promoção do fim" ${ }^{174}$; e (iii) “o exame da adequação só redunda na declaração de invalidade da medida adotada pelo Poder Público nos casos em que a incompatibilidade entre o meio e o fim for claramente manifesta". ${ }^{175}$

Considerando-se que pela padronização se busque, ainda que de forma presuntiva, uma base de igualdade geral, a análise da adequação no plano da generalidade surge neste caso, com maior expressividade. Sob este ponto de vista: "A medida será adequada se o fim for realizado na maioria dos casos com a sua adoção. Mesmo que exista um grupo não atingido ou casos em que o fim não foi realizado com aquela medida, só por isso ela não será considerada adequada". ${ }^{176}$

\section{A generalidade nas padronizações}

A padronização como medida eficiente para atingir a praticabilidade na tributação, ou seja, a realização eficiente da igualdade geral pela tributação só mostrar-se-á adequada se o padrão legal utilizado servir para a maioria dos casos, conseguindo-se generalizar uma classe de contribuintes numa classe de condições.

\footnotetext{
172 Para uma análise detalhada, consultar: ÁVILA, Humberto. Proporcionalidade e Direito Tributário. Revista Direito Tributário Atual, n.25. São Paulo: Dialética, 2011, p. 93-97.

173 ÁVILA, Humberto. Proporcionalidade e Direito Tributário. Revista Direito Tributário Atual, n.25. São Paulo: Dialética, 2011, p. 94.

${ }^{174}$ Ibidem, p. 95.

175 Ibidem, p. 97.

176 ÁVILA, Humberto. Proporcionalidade e Direito Tributário. Revista Direito Tributário Atual, n.25. São Paulo: Dialética, 2011, p. 95.
} 
Os pressupostos para que a generalidade seja alcançada e a padronização seja considerada uma medida adequada são: “(i) a desigualdade resultante do uso da padronização não for contínua nem considerável: se for contínua, o padrão deixa de refletir a média dos casos no tempo; se for considerável, o padrão afasta-se em demasia da média"177; (ii) "a desigualdade resultante do uso da padronização não atingir um número expressivo de contribuintes. Se isso ocorrer, o legislador terá desnaturado a padronização pela escolha de um caso atípico como modelo"178; (iii) a padronização só poderá provocar "efeitos de natureza acessória ou secundária relativamente aos direitos fundamentais, assim considerados aqueles efeitos que causam desigualdade rara e não previsível pelo legislador". ${ }^{179}$

A igualdade geral só será atingida por uma padronização que represente verdadeiramente o valor médio, considerado pela doutrina como requisito indispensável, conforme o pensamento de JARZYK-DEHNE, citado por HUMBERTO ÁvILA ${ }^{180}$ :

O princípio da igualdade da tributação de acordo com o parágrafo primeiro do artigo $3^{\circ}$. só está satisfeito quando a padronização apresenta resultados orientados para a realidade (wirklichkeitsgerchte Ergebnisse). Neste caso, orientado para a realidade não significa correspondência com a realidade em cada caso individual (...), mas que o resultado deva ser compatível com a realidade na média dos casos (im Durchschnitt der Fälle), isto é, que possa abranger a realidade de forma realista e generalizá-la. $E$ necessário que a padronização seja baseada numa análise média, numa avaliação média, em valores médios. Na construção de padronizações, o legislador não pode escolher casos atípicos como imagem de fundo. Ele deve orientar-se pela normalidade, pela média e manter uma relação razoável com os encargos médios.

\subsubsection{Proporcionalidade em sentido estrito}

No exame da proporcionalidade em sentido estrito deve-se apurar se os efeitos positivos da medida justificam as restrições causadas aos direitos fundamentais, no caso em tela, as vantagens causadas pela promoção da praticabilidade são proporcionais às desvantagens causadas pelas padronizações.

\footnotetext{
177 ÁVILA, Humberto. Imposto sobre a circulação de mercadorias: ICMS; substituição tributária; base de cálculo; pauta fiscal; preço máximo ao consumidor; diferença constante entre o preço usualmente praticado e o preço constante da pauta ou o preço máximo ao consumidor sugerido pelo fabricante; exame de constitucionalidade. Revista Dialética de Direito Tributário, n.123. São Paulo: Dialética, 2005, p. 127. Para explicar porque a padronização deve-se pautar pela média dos casos, o autor utiliza uma metáfora comparando a tributação com as roupas feitas sob medida e as de tamanho único. "A peça de 'tamanho único' deve ser adequada para a maior parte das pessoas, ainda que ela fique pequena para alguns e grande para outros, justamente porque o tamanho padrão deve servir para vestir a maioria, sem a necessidade de ajustes frequentes pelo alfaiate. Um 'tamanho único' que fique pequeno ou grande para a maioria das pessoas simplesmente não serve como tamanho único: primeiro porque exige precisamente aquilo que o uso do padrão quer evitar - o custo excessivo do reajuste contínuo, por ser impossível ou extremamente oneroso; segundo porque não corresponde ao tamanho médio das pessoas". Ibidem, p. 125.

${ }^{178}$ Ibidem, p. 128.

${ }^{179}$ Ibidem, p. 129.

180 ÁVILA, Humberto. Imposto sobre a circulação de mercadorias: ICMS; substituição tributária; base de cálculo; pauta fiscal; preço máximo ao consumidor; diferença constante entre o preço usualmente praticado e o preço constante da pauta ou o preço máximo ao consumidor sugerido pelo fabricante; exame de constitucionalidade. Revista Dialética de Direito Tributário, n.123. São Paulo: Dialética, 2005, p. 125.
} 
Já expusemos a tese de que a generalidade da lei é condição necessária para o próprio tratamento isonômico.

Nas situações em que a padronização é necessária alcança-se muito mais contribuintes do que uma tributação deficiente baseada na verificação da capacidade contributiva individual alcançaria e com isso haveria muito mais igualdade, o que implica dizer que as vantagens (igualdade plena para a grande maioria, sem o risco de alto grau de arbitrariedade pelo aplicador) superam proporcionalmente as desvantagens (eventuais diferenças individuais desfavoráveis a alguns contribuintes que são desprezadas). 


\subsection{Razoabilidade}

O postulado da razoabilidade decorre do princípio do Estado Democrático de Direito (art. $1^{\circ}$ da $\mathrm{CF} / 88$ ) que veda o exercício arbitrário do poder, funcionando como um mecanismo de controle da discricionariedade dos atos administrativos.

O exame de razoabilidade não se confunde com o exame de proporcionalidade. ${ }^{181}$ Neste a análise de adequação, necessidade e proporcionalidade decorrem da colisão entre princípios com base numa relação de meio e fim; naquele a análise de incompatibilidade entre uma regra geral e um caso excepcional. ${ }^{182}$

Nenhuma norma poderá ser aplicada sem atender às exigências do postulado da razoabilidade $^{183}$ e, por óbvio, que dentre elas, as normas simplificadoras que permitem a tributação com bases presuntivas, por intermédio das padronizações.

Essas normas, por força da razoabilidade, deverão harmonizar-se com a realidade, exigindo-se uma "causa real justificante para adoção"184 de tais medidas.

A causa real justificante é a realização eficiente da igualdade geral pela generalização por meio da tipificação ou padronização que, como vimos, não se afasta do

\footnotetext{
181 “Ao deixar de diferenciar a proporcionalidade da razoabilidade e da proibição de excesso, a doutrina esquece-se de que esses postulados (metanormas de aplicação de outras no caso de experiências conflituosas ou recalcitrantes ocorridas no plano concreto e da eficácia) servem de parâmetro para relacionar elementos diferentes em situações distintas". ÁVILA, Humberto. A Teoria dos Princípios e o Direito Tributário. Revista Dialética de Direito Tributário, n.125. São Paulo: Dialética, 2006, p.48. Nesse sentido: "A razoabilidade e a proporcionalidade como princípios de interpretação se assemelham, pois, ao evitarem a consumação do ato socialmente iníquo e inaceitável, impõem a consideração de todas as nuances do caso concreto submetido à regulação; neste sentido, pode-se afirmar que ambas derivam da mesma raiz; todavia não se confundem, a permitir que uma noção possa ser reduzida à outra, isto é, a existência de pontos de contato entre aqueles dois princípios não significa que sejam fungíveis entre si". PONTES, Helenilson Cunha. O Princípio da Proporcionalidade e o Direito Tributário. São Paulo: Dialética, 2000, p. 88-89.

Discordando dessa tese Regina Helena Costa: "Pensamos, assim, que "razoabilidade" e "proporcionalidade" sejam temas fungíveis, a significarem diretriz implícita fundamentada nas ideias de devido processo legal substantivo e de justiça, com vista à proibição de arbitrariedade. COSTA, Regina Helena. Praticabilidade e justiça tributária - Exequibilidade de Lei Tributária e Direitos do Contribuinte, São Paulo: Malheiros, 2007, p. 128.

182 ÁVILA, Humberto. A Teoria dos Princípios e o Direito Tributário. Revista Dialética de Direito Tributário, n.125. São Paulo: Dialética, 2006, p.48.

183 "A jurisprudência do Supremo Tribunal Federal atribui ao chamado princípio da razoabilidade a fonte para várias exigências. Em primeiro lugar, a razoabilidade exige a harmonização da norma geral com os casos individuais. [...]Em segundo lugar, a razoabilidade impõe a harmonização das normas com as suas condições externas de aplicação. Nessa hipótese, a razoabilidade exige uma causa real justificante para a adoção de qualquer medida. [...]Além disso, a razoabilidade exige uma relação de congruência entre o fundamento para a diferenciação entre sujeitos e a norma que estabelece a diferenciação. [...]Em terceiro lugar, a razoabilidade exige uma relação de equivalência entre a medida adotada e o critério que a dimensiona. [...] Em quarto lugar, e segundo a jurisprudência do Tribunal de Justiça do Estado do Rio Grande do Sul, a razoabilidade exige uma relação de coerência lógica, quer no sentido de consistência interna entre as normas jurídicas (p. ex., não é razoável uma lei municipal que estabelece uma obrigação para um sujeito e direciona a punição para outro), quer no sentido de consistência externa na norma com circunstâncias necessárias a sua aplicação (p. ex., não é razoável uma lei que impõe uma obrigação que não poderá ser tecnicamente cumprida, desde a edição, porque o órgão incumbido de cumpri-la não é capacitado nem competente para tanto)". ÁVILA, Humberto. A Teoria dos Princípios e o Direito Tributário. Revista Dialética de Direito Tributário, n.125. São Paulo: Dialética, 2006, p.42-43.

${ }^{184}$ Ibidem, p. 42
} 
princípio da igualdade, mas ao contrário, "serve precisamente de instrumento para a sua realização". ${ }^{185}$

Sobre essa consideração, muito pertinente a observação de que "a simplificação e a economia de gastos não podem ser consideradas propriamente como finalidades da padronização. Elas são consequências almejadas com a padronização, mas a finalidade continua sendo a realização eficiente da igualdade geral". ${ }^{186}$

Se a realização eficiente da igualdade geral é a causa real justificante, a norma geral simplificadora deverá, também por força do princípio da razoabilidade, harmonizar-se com os casos individuais. ${ }^{187}$

A generalização, pela padronização, será mantida como regra geral, desde que o padrão adotado seja representativo da grande maioria dos casos. Isto não quer dizer que discrepâncias significativas, em determinados casos individuais, não possam ser objeto de superação. Harmonizar a norma geral com os casos individuais é não abandonar, mesmo na igualdade geral das padronizações, a comparação com a igualdade individual, mantida como critério de comparação na tributação.

A vinculação da padronização com a realidade, por força da razoabilidade, deve ocorrer tanto em momento anterior ${ }^{188}$ à formação do padrão, quando por meio de dados consistentes consegue-se demonstrar a validade, para a maioria dos casos, do valor médio efetivo, quanto em momento posterior, quando o cotejamento permanente entre a base real do fato tributário e o valor padrão permite verificar sua consistência e aplicabilidade.

Em razão do exposto pode-se afirmar que "os padrões, como espécie de presunções, nunca abandonam a realidade: não o fazem antes, porque dela decorrem para existir; não o fazem depois, porque dela dependem para permanecer". ${ }^{189}$

Do postulado da razoabilidade infere-se que o valor padrão deverá refletir o valor real médio, sob pena de uma realização irrazoável ${ }^{190}$ de igualdade, e que do seu cotejamento

\footnotetext{
185 ÁVILA, Humberto. Teoria da Igualdade Tributária. 2a . edição. São Paulo: Malheiros, 2009, p. 91.

${ }^{186}$ Ibidem, p. 91.

187 ÁVILA, Humberto. A Teoria dos Princípios e o Direito Tributário. Revista Dialética de Direito Tributário, n.125. São Paulo: Dialética, 2006, p.42.

188 "Sem uma base empírica que permita verificar a dimensão média dos valores, não se atende ao princípio da igualdade geral, pois - eis o ponto - ela exige uma vinculação com a realidade média dos fatos. Essa vinculação decorrente de uma base empírica ampla e visível, não atende apenas à efetivação da igualdade por meio do critério de capacidade contributiva concreta. Ela atende, também, aos princípios da publicidade e do devido processo legal: da publicidade, porque, sem uma pesquisa que sirva de base à padronização, não se dá transparência à atividade administrativa, nem se fundamenta o seu exercício; do devido processo legal, porque, sem uma pesquisa específica o contribuinte a rigor, não tem como controlar a regularidade do padrão por meio do exercício da ampla defesa e do contraditório". ÁVILA, Humberto. Teoria da Igualdade Tributária. $2^{\mathrm{a}}$. edição. São Paulo: Malheiros, 2009, p. 90.

189 ÁVILA, Humberto. Teoria da Igualdade Tributária. 2a . edição. São Paulo: Malheiros, 2009, p. 90.

190 ÁVILA, Humberto. Imposto sobre a circulação de mercadorias: ICMS; substituição tributária; base de cálculo; pauta fiscal; preço máximo ao consumidor; diferença constante entre o preço usualmente praticado e o preço constante da pauta ou o preço
} 
permanente com a realidade seja possível questionar sua correspondência efetiva com a média das operações efetivamente praticadas, quando as discrepâncias entre o seu valor e o valor real ocorrerem em um número de casos significativos.

Ainda que a regra geral de padronização seja válida, por obedecer aos exames de proporcionalidade e razoabilidade, pode ocorrer que de sua aplicação, relativamente a alguns contribuintes, as diferenças entre a base presumida e a real sejam de tal magnitude, que venham a se constituir em confisco, vedado por nosso ordenamento. ${ }^{191}$

Por essa razão a doutrina aponta a necessidade de que "qualquer padronização deve ter cláusulas de abertura ou de equidade (Harteklausen), que possam evitar determinados rigorismos e proporcionar uma diferenciação concretamente justa". ${ }^{192}$

Essas cláusulas que possibilitam o retorno da igualdade geral, promovida pela padronização, à igualdade particular privilegiada pela Constituição, podem ser de dois tipos: (i) cláusulas que garantem à voluntariedade e opcionalidade ao regime objetivo, atuando desta forma em momento anterior à aplicação do tributo com bases presuntivas; e (ii) cláusulas que permitem a devolução das diferenças em momento posterior à tributação.

Passemos à análise dessas cláusulas.

\subsubsection{O caráter voluntário e opcional dos regimes objetivos}

O princípio da capacidade contributiva atua tanto como proteção ao contribuinte, dando-lhe uma garantia individual de que não será tributado além de sua riqueza disponível, como dever do Estado de captar pela tributação, nesta riqueza disponível, os recursos necessários para atingimento de suas necessidades de forma justa e generalizada.

Diante desse dever, parte da doutrina entende não ser possível deixar a opção ao contribuinte de um método de tributação com base presumida, quando este, eventualmente, permitir-lhe-á reduzir o valor do tributo a pagar caso fosse utilizada a base efetiva.

CÉSAR NovoA, citando Cortés Domí́ngueZ-MARTÍn DELGADO, aponta que uma das críticas aos regimes de estimação objetiva seria por permitirem uma "legalización del fraude; ya que aunque las bases determinadas por el procedimento de evaluación global sean

máximo ao consumidor sugerido pelo fabricante; exame de constitucionalidade. Revista Dialética de Direito Tributário, n.123. São Paulo: Dialética, 2005, p. 128.

191 Vide Não-Confisco.

192 ÁVILA, Humberto. Teoria da Igualdade Tributária. 2a . edição. São Paulo: Malheiros, 2009, p. 105. 
inferiores a las que corresponderían si se aplicasse la Ley del impuesto, aquéllas tienen el caráter de firmes y no pueden ser modificadas por la Administración"193.

LEONARDo SPERB DE PAOla apesar de considerar que deixar ao bel prazer do contribuinte a escolha do método de tributação que melhor lhe sirva, enfraquece "o caráter público do Direito Tributário"194, também entende que em determinadas situações, quando, por exemplo, a utilização de outros métodos de tributação que busquem a efetiva base de cálculo gerassem custos maiores que os tributos arrecadados, outros valores deveriam ser ponderados, justificando esse caráter voluntário e opcional, sem que houvesse ofensa "ao ideal de justa distribuição de carga tributária". ${ }^{195}$

Os exames de proporcionalidade e razoabilidade da norma simplificadora padronizante exigem que as vantagens sejam proporcionais às desvantagens pela adoção ao regime e que não se abandone o vínculo entre a base presumida e a dimensão real do fato tributário, nem em momento anterior, nem em momento posterior à aplicação da padronização.

O caráter voluntário e opcional destes regimes colabora para a vinculação com a realidade em momento anterior à padronização. É que os próprios contribuintes, utilizando-se de sua base histórica de operações e transações, poderão comprovar se o padrão utilizado pelo fisco corresponde ao valor médio efetivo de suas operações e, desta forma, poderão voluntariamente fazer a opção pelo regime objetivo de estimação, aproveitando-se de eventuais reduções na carga tributária, ou da diminuição de obrigações acessórias que normalmente acompanham esses regimes.

Se, por outro lado, o contribuinte verificar que as diferenças entre o padrão e seu valor efetivo são de tal ordem que redundarão em desvantagem, certamente abdicará da opção pelo regime, o que demonstra que o caráter voluntário e opcional trabalha também no sentido de atender às exigências da proporcionalidade e razoabilidade.

Podemos acrescentar que o caráter voluntário e opcional dos regimes de estimação objetiva vem ao encontro da previsibilidade e, consequentemente, da segurança jurídica.

Assim, por exemplo, no caso do imposto de renda das pessoas jurídicas, o contribuinte poderá de forma voluntária, após realizar suas previsões e estimar qual o regime de tributação que lhe seja mais benéfico, optar (ou não) pelo regime de lucro presumido.

\footnotetext{
${ }^{193}$ NOVOA, César Garcia. Los métodos de simplificatión fiscal em la experiência latino americana. Referencia comparativa a los casos brasileno y argentino. Revista de Contabilidad y Tributación del Centro de Estudios Financieros, n. 59. Madri, outubro/2003, p. 71. Em razão desta distorção o modelo de estimação objetiva foi suplantado pelo "sistema híbrido de estimación objetiva singular" resultando em que "la admissibilidade de las estimaciones objetivas suele harcerse depender, además del dato de que las mismas tengam caráter voluntario u opcional, de su referencia individual, descartándose las fórmulas globales de estimación objetiva". Ibidem, p. 71.

${ }_{194}$ PAOLA, Leonardo Sperb de. Presunções e ficções no direito tributário. Belo Horizonte: Del Rey, 1997, p. 146.

${ }^{195}$ Ibidem, p. 146.
} 
Essa opção também é possível em outros regimes, como por exemplo, no desconto simplificado para o imposto de renda da pessoa física e no caso do Simples Nacional.

Esse caráter opcional e voluntário, estamos convencidos, permite corrigir eventuais distorções, que em alguns casos singulares poderão ocorrer, colaborando sobremaneira para a certeza e previsibilidade, aspectos cruciais para a segurança jurídica nas relações tributárias.

\subsubsection{Ajustabilidade}

A igualdade geral, promovida pela imposição do regime objetivo, pode trazer discrepâncias significativas entre o valor presumido e o valor real, de tal ordem, que há a obrigação do legislador ${ }^{196}$ prever cláusulas de abertura ou equidade que permitam ajustar essas diferenças, com a devolução das quantias que sejam significativas.

Será que a essa ajustabilidade não compromete a própria padronização? Será que analisar cada caso individual, onde se alega uma discrepância em razão da padronização, não iria implicar na impraticabilidade na aplicação do tributo, que foi a justificativa para a utilização da própria padronização? Estamos diante de um problema tautológico?

No julgamento da ADIn 1851-4 de Alagoas, o Supremo Tribunal Federal decidiu que não há restituição ou complementação do imposto pago na substituição tributária para frente, com base que tais atividades a serem desempenhadas pelo fisco comprometeriam as vantagens da redução de evasão, comodidade, economia, eficiência e celeridade alcançadas pelo princípio da praticabilidade. Vejamos a ementa:

O fato gerador presumido, por isso, não provisório, mas definitivo, não dando ensejo
à restituição ou complementação do imposto pago, senão, no primeiro caso, na
hipótese de sua não-realização final. Admitir o contrário valeria por despojar-se o
instituto das vantagens que determinaram a sua concepção e adoção, com a redução,
a um só tempo, da máquina-fiscal e da evasão fiscal a dimensões mínmas,
propiciando, portanto, maior comodidade, economia, eficiência e celeridade às
atividades de tributação e arrecadação. ${ }^{197}$

Admitir uma tributação com base presumida, mas sem direito à restituição de valor comprovadamente pago a maior, como no caso em tela, representa considerar irrelevantes e inoperantes os mandamentos constitucionais de proporcionalidade, razoabilidade, capacidade contributiva, igualdade, não confisco entre outros.

196 ÁVILA, Humberto. Teoria da Igualdade Tributária. 2a . edição. São Paulo: Malheiros, 2009, p. 105-106.

${ }^{197}$ STF, ADIn 1.851/Al Rel. Min. Ilmar Galvão, Ementa, j. 13.12.2002. 
Por outro lado, admitir que o fisco tivesse que recepcionar e auditar cada pedido de restituição, verificando sua comprovação, seria ferir de morte o princípio da praticabilidade, tornando impraticável a aplicação e gerenciamento do tributo.

As respostas para essas questões não estão em verificar as consequências, mas sim perquirir a causa, isto é, aferir a validade do padrão utilizado:

\begin{abstract}
Neste aspecto, é preciso ter em conta que os padrões, como quaisquer regras gerais, são instrumentos de tributação previsível, eficiente e geralmente equânime. Como, porém, para serem válidos, os padrões só podem causar desigualdade de pouco alcance, extensão e intensidade, a sua superação em casos marginais não tem como gerar elevada imprevisibilidade, ineficiência e desigualdade. ${ }^{198}$
\end{abstract}

Assim, a ajustabilidade, sem anular as vantagens da padronização, só será justificada quando os casos onde ocorrerem discrepâncias significativas forem verdadeiramente excepcionais, de modo que eventuais análises e devoluções, por parte da administração fazendária, não impliquem em recursos humanos e custos que inviabilizariam as vantagens trazidas pela padronização.

Caso contrário, se o número de casos desviados do padrão legal for elevado, o problema reside não na quantidade de desvios e, sim, nos requisitos de generalidade do padrão utilizado, ou dito de outra forma, “[...] se a padronização é válida, a cláusula de retorno à igualdade particular não inibe seus efeitos positivos; se inibe, é porque a padronização não é válida". ${ }^{199}$

Embora a doutrina sempre faça a análise da validade do padrão do ponto de vista do contribuinte, entendemos que os requisitos de generalidade e compatibilidade do padrão devem ser atendidos do ponto de vista da administração fiscal.

O fisco apura um valor padrão de operação, utilizando sua base de dados histórica e, frequentemente, pela consulta aos órgãos representativos de determinado setor (p. ex.

\footnotetext{
${ }^{198}$ STF, ADIn 1.851/Al Rel. Min. Ilmar Galvão, Ementa, j. 13.12.2002, p. 106.

199 ÁVILA, Humberto. Teoria da Igualdade Tributária. 2a. edição. São Paulo: Malheiros, 2009, p.106. Muito ilustrativa a metáfora do mito do leito de Procusto com a padronização: "Procusto era um ladrão de estrada que atraía os viajantes com a promessa de um jantar e uma boa noite de sono numa cama que lhes cairia perfeitamente. O que ele não contava, porém, é qie ele só tinha uma cama: se o visitante era pequeno demais, ele o esticava até caber perfeitamente na cama; se era grande demais, cortava-lhe os pés ou, em algumas versões do mito, decepava-lhe a cabeça. Isso foi feito até que Theseu visitou Procusto e fez com ele o que ele fazia com os viajantes que atraía. O que esse mito ilustra é precisamente a uniformidade com que a padronização trata os contribuintes, 'enquadrando-os' numa única 'cama-padrão' (da pauta, da tabela, da planta de valores). Aplicando essa ilustrativa metáfora ao caso da padronização, o legislador não pode, a pretexto de encaixar o contribuinte na cama, nem cortar-lhe a cabeça, nem esticá-lo tanto que provoque sua morte, pois isso seria excessivo, nem cortar qualquer parte do corpo ou estica-lo sem uma justificativa tão mais relevante quanto maior for o desconforto que lhe cause, pois isso seria arbitrário". Ibidem, p. 112.
} 
plásticos, borrachas, produtos químicos etc.). Este valor padrão calculado pode não representar o valor médio efetivo, causando prejuízos tanto ao contribuinte, como ao próprio físco.

Se os prejuízos para o contribuinte são ajustados com a devolução de valores, o prejuízo ao erário também deverá ser reparado pela cobrança do valor de tributo pago a menor. Sem os ajustes, o princípio da igualdade ficará irremediavelmente comprometido.

Essas considerações demonstram que se a praticabilidade traz simplificações ao fisco na aplicação e fiscalização dos tributos, ela também traz a obrigação da eficiência, publicidade e transparência na avaliação das bases presumidas.

A eficiência para que, detectada uma inadequação significativa do padrão adotado com a realidade, de forma célere, faça a adequação de forma a minimizar os impactos negativos tanto aos contribuintes, quanto ao fisco.

Publicidade e transparência nos métodos utilizados para apuração dos valores, reunindo-se sempre que possível aos órgãos representativos da classe dos contribuintes envolvidos, de maneira a garantir, pela via administrativa e judicial, o controle do valor padrão utilizado.

A ajustabilidade ao extremo, como referido, pode levar à superação do padrão utilizado. Ocorre que há padrões e padrões, ou seja, um padrão, dependendo dos princípios e valores envolvidos, poderá ser mais resistente à sua superação do que outro?

É inerente à padronização desconsiderar aspectos subjetivos da capacidade contributiva, assim, por exemplo, no imposto sobre a renda, como forma de padronizar, são criados vários limites de dedução de despesas, como forma de apurar uma base presuntiva da riqueza disponível.

Vamos supor uma pessoa que receba rendimentos tributáveis de alugueres, mas por se encontrar enferma, obriga-se a manter enfermeiros e custear medicamentos caros durante o tratamento, comprometendo integralmente seus rendimentos. "Terá ela, talvez, capacidade econômica; de capacidade contributiva, entretanto, não cabe cogitar". ${ }^{200}$

Neste exemplo, a padronização pelo limite de dedução com gastos de saúde tem a mesma resistência que uma outra padronização que considera outros limites de dedução com despesas menos importantes?201

HUMBERTO ÁviLA preconiza que a análise da superação ${ }^{202}$ do padrão deve-se dar em dois eixos: formal e substancial.

\footnotetext{
200 SCHOUERI, Luís Eduardo. Direito Tributário. São Paulo: Saraiva, 2011, p. 313.

201 ÁVILA, Humberto. Teoria da Igualdade Tributária. 2 ${ }^{\mathrm{a}}$. edição. São Paulo: Malheiros, 2009, p.108.

${ }^{202}$ Segundo o autor a superação do modelo de padronização só poderá ocorrer após um procedimento de fundamentação e comprovação, razão pela qual ele afirma que o modelo adotado constitucionalmente não pode ser visto apenas como um modelo
} 
Do ponto de vista formal, "quanto mais a superação do padrão legal colocar em perigo a própria justificação da padronização, enquanto solução eficiente, módica e geralmente equânime de controvérsias, tanto mais resistente deve ser o padrão em questão". ${ }^{203}$

Pelo eixo substancial deve-se atentar para duas regras: (i) "quanto mais importante for o princípio subjacente ao padrão, tanto menor deverá ser sua resistência à superação"204; e (ii) "quanto mais importante for o bem jurídico valorizado pelo padrão para determinado princípio, tanto menor deverá ser sua resistência à superação". ${ }^{205}$

Levando-se em conta essas regras é possível afirmar, que no caso em tela, o limite de deduções com despesas de saúde deverá ter uma resistência menor à superação da padronização ${ }^{206}$ do que, por exemplo, o limite de dedução com despesas de transporte, porque: (i) o princípio da proteção à saúde é mais importante que o princípio da locomoção; e (ii) a vida e a dignidade humana são bens jurídicos mais importantes do que o direito de ir e vir.

Antes de encerrarmos este tópico sobre a apreciação das padronizações e seus efeitos, queremos chamar a atenção para o fato de que embora ao poder legislativo seja permitido a persecução da justiça geral pela praticabilidade, tal consentimento não é dado ao poder judiciário, pois, conforme leciona MISABEL DERZI ${ }^{207}$ :

O princípio da praticidade, que se utiliza de presunções, tipificações, pautas e plantas de valores, informa a aplicação da lei em massa. Mas ele não pode afastar o Poder Judiciário do cumprimento de seu papel institucional, que é o dever de prover a justiça individual, caso a caso.

Desta feita, o Poder Judiciário, que tem o dever institucional de promover a distribuição da justiça individual, não pode se furtar de examinar cada caso concreto, ainda que o executivo não o tenha feito, utilizando-se de uma padronização considerada válida, por atender aos requisitos de generalidade e compatibilidade.

\footnotetext{
moderado de igualdade particular, mas também como um modelo procedimentalizado: "De fundamentação, porque é preciso exteriorizar, de modo racional e transparente, as razões que permitem a superação do padrão. Somente a exteriorização escrita, juridicamente fundamentada e logicamente estruturada de existência de diferenças de grande alcance, extensão ou intensidade, ou de disparatada qualidade, entre o fato presumido e o ocorrido, é que permite sua desconsideração concreta. De comprovação, porque as diferenças de grande alcance, extensão ou intensidade, ou de disparatada qualidade, entre o fato presumido e o ocorrido, devem ser instruías com a comprovação de sua existência, como documentos, perícias ou estatísticas”. ÁVILA, Humberto. Teoria da Igualdade Tributária. 2a . edição. São Paulo: Malheiros, 2009, p.110.

${ }^{203}$ ÁVILA, Humberto. Teoria da Igualdade Tributária. 2a. edição. São Paulo: Malheiros, 2009, p.108.

${ }^{204}$ Ibidem, p. 109.

${ }^{205}$ Ibidem, p. 109.

206 Ibidem, p. 109.

${ }^{207}$ DERZI, Misabel de Abreu Machado. Direito tributário, direito penal e tipo, 2. ed. São Paulo: Revista dos Tribunais, 2008, p. 359.
} 


\subsection{Neutralidade}

Neutralidade padece, como muitos outros vocábulos, de plurissignificação, cabendo-nos verificar entre as várias acepções possíveis, qual delas estaremos tratando.

Inicialmente cabe destacar que não se pode imaginar um tributo neutro. O Estado ao tributar, com a finalidade de distribuir renda ${ }^{208}$, acaba afetando a neutralidade do próprio sistema econômico.

Os tributos sejam aqueles com finalidade fiscal, sejam aqueles com finalidade extrafiscal induzem comportamentos nos contribuintes, razão pela qual, não se pode esperar, que o Estado ao tributar, não irá exercer qualquer influência de comportamento. Neste sentido tributação e neutralidade são incompatíveis.

Não é este o sentido da neutralidade que buscamos, mas sim o dever estatal de não influenciar a livre concorrência pela tributação.

Como define SCHOUERI: "A Neutralidade Tributária não significa a não interferência do tributo sobre a economia, mas, em acepção mais restrita, neutralidade da tributação em relação à Livre Concorrência, visando a garantir um ambiente de igualdade de condições competitivas, reflexo da neutralidade concorrencial do Estado". ${ }^{209}$

MiSABEL DERZI"10 aponta que: "Ser neutro significa tanto ser indiferente na competitividade e concorrência, quanto na formação de preços de mercado".

De forma similar HUMBERTO ÁvILA expõe que: "a neutralidade evidencia o dever de atuação ou abstenção estatal em determinado nível relativamente aos efeitos que a tributação provoca quando recai sobre bens jurídicos essenciais à realização do princípio da liberdade de concorrência". ${ }^{211}$

\footnotetext{
${ }^{208}$ Os efeitos na economia que decorrem da tributação são: “distributivos: quando se tem em conta que é possível, com a tributação, redistribuir a renda, tirando mais de uns e aplicando mais em favor de outros. No Estado Social, a redistribuição visa à redução de desigualdades sociais; alocativos: quando se tem em conta que a própria incidência do tributo não é neutra sobre a economia, pois acaba por ter reflexos na forma como a totalidade dos recursos é dividida para utilização no setor público e no setor privado. Reflexo da função alocativa, tem-se a indução de comportamentos. Afinal, a tributação se vincula a comportamentos humanos e a incidência tributária passa a ser um fator a ser considerado na própria decisão do agente econômico; estabilizadores: quando se tem em conta que a política fiscal deve ser formulada objetivando alcançar ou manter um elevado nível de emprego, uma razoável estabilidade no nível de preços, equilíbrio na balança de pagamentos e uma taxa aceitável de crescimento econômico". SCHOUERI, Luís Eduardo. Direito Tributário. São Paulo: Saraiva, 2011, p. 33.

${ }^{209}$ SCHOUERI, Luís Eduardo. Direito Tributário. São Paulo: Saraiva, 2011, p. 333.

210 DERZI, Misabel de Abreu Machado. Distorções no Princípio da Não-Cumulatividade no ICMS- Comparação com o IVA EUROPEU. In: Temas de Direito Tributário. Belo Horizonte: Del Rey, 1998, p. 119.

211 ÁVILA, Humberto. Teoria da Igualdade Tributária. 2a. edição. São Paulo: Malheiros, 2009, p. 99.
} 
Pode-se dizer que a neutralidade é o dever do Estado garantir uma igualdade de chances $^{212}$ para os contribuintes no mercado, buscando igualar a carga tributária em situações similares.

A neutralidade representa, por essa análise, uma limitação para a atuação do legislador tributário na instituição de padronizações. Se pela padronização houver uma elevação de preços que resultaria a determinado contribuinte uma situação concorrencial desfavorável frente aos seus concorrentes, estaríamos diante de uma padronização inválida que, por prejudicar a livre concorrência, não estaria atendendo às exigências da neutralidade.

Vamos por hipótese imaginar um comerciante que vende uma cerveja em um bairro da periferia e outro comerciante que vende a mesma cerveja em um bairro nobre com preço bem superior.

Se a padronização elevar o preço para próximo do valor comercializado no bairro nobre, os comerciantes deste bairro, que vendem a cerveja com preço superior e uma margem de lucro bem maior, suportariam a mesma carga tributária daqueles comerciantes da periferia que praticam um preço menor e consequentemente uma margem de lucro bem menor.

Por outra via, se a padronização baixar o preço para próximo do valor praticado pelo comerciante do bairro mais modesto, teríamos uma violação ao princípio da igualdade ao tratar igualmente contribuintes que se encontram em situações diferenciadas. O contribuinte da periferia embora revele um potencial econômico menor estaria arcando com um gravame maior relativamente à margem de lucro obtida.

A padronização pode ocasionar esta situação extremamente desfavorável à livre concorrência, onerando mais intensamente determinado grupo de contribuintes, ao obstaculizar "a liberdade de tomar decisões e de competir num mercado livre, especialmente pelo poder de fixar uma política ou estratégia comercial, intimamente relacionada com a livre fixação de preços". ${ }^{213}$

Ainda que seja de fácil assimilação a ideia da neutralidade ser fundamental para a igualdade e livre concorrência, existe muita dificuldade em sua aplicação. ${ }^{214}$

Para o nosso enfoque, cabe observar que a neutralidade pode ser afetada, quando contribuintes que se encontravam em igualdade de oportunidade em determinado setor, após a

\footnotetext{
${ }^{212}$ Humberto Ávila citando Vogt afirma: “enquanto o dever de neutralidade de concorrência (Wettbewerbsneutralität) garante a igualdade de chances (Chancengleichheit) no processo de trabalho (Erwerbsvorgang), a capacidade contributiva garante a igualdade de oneração (Belastungsgleischheit) relativamente àquilo já obtido (das Erworbene)". ÁVILA, Humberto. Teoria da Igualdade Tributária. 2a . edição. São Paulo: Malheiros, 2009, p. 99.

${ }^{213}$ ÁVILA, Humberto. Teoria da Igualdade Tributária. 2a . edição. São Paulo: Malheiros, 2009, p. 100.

214 ÁVILA, Humberto. Teoria da Igualdade Tributária. 2a . edição. São Paulo: Malheiros, 2009, p. 101-103.
} 
implementação da padronização fiquem em desvantajosa situação de concorrência. Neste caso, a padronização deverá ser repensada ou extinta, privilegiando-se a livre concorrência.

Ao se restringir a livre concorrência por uma regra geral que institua o tributo com base presuntiva, restringir-se-ão também, o desenvolvimento e a existência digna, fundamentos do Estado Democrático de Direito. ${ }^{215}$

\footnotetext{
215 Ao tratar do fundamento da nossa Ordem Econômica Luís Eduardo Schoueri faz importante observação: "Esta Ordem Econômica, por sua vez, não existe para assegurar a Livre-Iniciativa nem a Livre Concorrência. Ela existe para assegurar a todos a existência digna Esta é a razão de ser da Ordem Econômica fundada na Livre-Iniciativa. Uma ordem econômica que esteja baseada na Livre-Iniciativa mas que não tenha por finalidade assegurar a existência digna a todos não é aquela preconizada pelo Constituinte. Não merece proteção constitucional uma tal ordem”. SCHOUERI, Luís Eduardo. Direito Tributário. São Paulo: Saraiva, 2011, p. 330.
} 


\subsection{Proibição do Efeito de Confisco}

A proibição aos entes federados de utilizar os tributos com efeito de confisco está expressamente prevista no art. 150, IV, da CF/88, configurando-se uma das limitações impostas pela nossa ordem constitucional ao poder de tributar.

O princípio do não confisco, ou princípio da proibição do efeito de confisco é expressão de garantia ao direito de propriedade ${ }^{216}$, direito fundamental assegurado no art. $5^{\circ}$., caput, da Carta Magna ${ }^{217}$, entre outros direitos fundamentais.

Atingir um direito fundamental, como o direito de propriedade, pelo confisco remete-nos à proibição de excesso que está fundamentada na "ideia de que todos os direitos e princípios fundamentais, ainda que possam ser restringíveis, não podem ser atingidos no seu núcleo essencial, sendo esse núcleo definido como aquela parte do conteúdo de um direito sem a qual ele perde a sua mínima eficácia e, por isso, deixa de ser reconhecível como um direito fundamental". ${ }^{218}$

O confisco pode expressar o limite máximo a ser observado na captação da riqueza tributável no aspecto subjetivo da capacidade contributiva nos tributos com finalidade fiscal, ou na vedação ao excesso na tributação em obediência aos princípios da proporcionalidade e razoabilidade na tributação quando estiverem em cena razões extrafiscais.

Determinar critérios objetivos que possibilitem determinar se determinado tributo é confiscatório não é tarefa simples. A solução doutrinária remete à absorção do patrimônio, como Regina Helena Costa que define o confisco como "medida de caráter sancionatório, consistente na absorção total ou substancial da propriedade privada pelo Poder Público sem a correspondente indenização". ${ }^{219}$

Outra tentativa é instituir o mínimo existencial como limite à tributação: "todo e qualquer tributo que incida sobre o mínimo existencial tem efeito confiscatório". ${ }^{220}$

\footnotetext{
${ }^{216}$ Esse é o entendimento de Regina Helena Costa: “[...]assim como o direito de propriedade não pode ser indevidamente restringido ou aniquilado pela tributação, outros direitos constitucionais, igualmente não podem ser cerceados, tais como a liberdade de iniciativa, o direito à saúde e o direito à educação, pois, se, de um lado, o ordenamento constitucional os incentiva e ampara, não pode, ao mesmo tempo, compactuar com a obstância ao seu exercício por uma atividade tributante desvirtuada". COSTA, Regina Helena. Praticabilidade e justiça tributária - Exequibilidade de Lei Tributária e Direitos do Contribuinte, São Paulo: Malheiros, 2007, p. 172.

${ }^{217} \mathrm{CF} / 88$. Art. $5^{\circ}$ Todos são iguais perante a lei, sem distinção de qualquer natureza, garantindo-se aos brasileiros e aos estrangeiros residentes no País a inviolabilidade do direito à vida, à liberdade, à igualdade, à segurança e à propriedade, nos termos seguintes:[...].

218 ÁVILA, Humberto. Teoria da Igualdade Tributária. 2a . edição. São Paulo: Malheiros, 2009, p. 104.

${ }^{219}$ COSTA, Regina Helena Costa. Princípio da Capacidade Contributiva. 3. ed. São Paulo: Malheiros, 2003. p. 79.

${ }^{220}$ YAMASHITA, Douglas. Confisco como efeito tributário e sua proibição constitucional. Repertório IOB de Jurisprudência. Belo Horizonte, n. 10, p. 263, 2a. quinzena, maio. 2000. Caderno 1. Destacando a relevância do mínimo existencial: "O mínimo existencial é constitucionalmente intocável, inalienável, já que até mesmo uma contribuição de melhoria poderia 'matar de
} 
Mas ao tentar caracterizar o que seria uma absorção total ou substancial, ou ainda qual seria o mínimo existencial, retornaríamos à apreciação subjetiva do problema.

A solução será encontrada na análise do caso concreto, cabendo ao Poder Judiciário $^{221}$, com base na equidade e na razoabilidade, apontar os limites da confiscatoriedade. Concordamos com FloREnCE HARET que "O confisco, como valor, é indeterminável, pede um objeto concreto para valorar. Sua definição objetiva ou seus limites no mais da vezes se apresentarão tão só na solução do caso em concreto, e mesmo assim, sendo impossível dele obter regra geral que o determine em termos genéricos". ${ }^{222}$

Na jurisprudência do STF, o voto do Ministro Sepúlveda Pertence no julgamento da ADI 551/RJ, já tornou-se referência neste tema de definir o que é ou não confisco:

$[\ldots]$

Recorda-me, no caso, o célebre acórdão do Ministro Aliomar Baleeiro, o primeiro no qual o Tribunal declarou a inconstitucionalidade de um decreto-lei, por não compreender no âmbito da segurança nacional. Dizia o notável Juiz desta Corte que ele não sabia o que era segurança nacional; certamente sabia o que não era: assim, batom de mulher ou, o que era o caso, locação comercial.

Também não sei a que altura um tributo ou uma multa se torna confiscatório; mas uma multa de duas vezes o valor do tributo, por mero retardamento de sua satisfação, ou de cinco vezes, em caso de sonegação, certamente sei que é confiscatório e desproporcional. ${ }^{223}$

No caso da praticabilidade, a norma simplificadora padronizante não poderá atingir o direito fundamental de propriedade, sob pena da inconstitucionalidade pelo confisco, "com efeito, perdendo-se de vista a riqueza individual, pela utilização de médias, pode-se retirar uma parcela considerável da riqueza de determinado contribuinte - e uma parcela mínima da de outro. A tributação às cegas tanto pode atingir muito pouco, como demais". ${ }^{224}$

A observação ao princípio da proibição de excesso pela tipificação, como verdadeiro limite às técnicas de simplificação, foi ressaltada por CASALTA NABAIS:

Compreende-se que o recurso a uma tal técnica tenha limites, ficando pois a liberdade tipificadora do legislador sujeita a barreiras, cujo respeito cabe ao juiz controlar, com alguma latitude e razoável eficácia naqueles sistemas de controle de constitucionalidade das leis que conhecem a modalidade do controle concreto, em que a conformidade das normas é testada enquanto aplicadas aos casos concretos. Entre

fome, frio ou doença não medicada' assalariados mínimos beneficiados com a valorização imobiliária de seus imóveis”. Ibidem, p. 263.

${ }^{221}$ Neste sentido: "Uma definição objetiva, genérica e exaustiva sobre o princípio do não-confisco não é possível. Apenas o Poder Judiciário, como único intérprete legítimo, poderá julgar e aplicar tal princípio caso a caso”. YAMASHITA, Douglas. Confisco como efeito tributário e sua proibição constitucional. Repertório IOB de Jurisprudência. Belo Horizonte, n. 10, p. 259, 2a. quinzena, maio. 2000. Caderno 1; COSTA, Regina Helena. Praticabilidade e justiça tributária - Exequibilidade de Lei Tributária e Direitos do Contribuinte, São Paulo: Malheiros, 2007, p. 118; HORVATH, Estevão. O Princípio do NãoConfisco no Direito Tributário. São Paulo: Dialética, 2002.

222 HARET, Florence. Teoria e Prática das Presunções no Direito Tributário. São Paulo: Noeses, 2011, p. 606.

${ }^{223}$ STF, Tribunal Pleno, ADI 551/RJ, Rel. Min. Ilmar Galvão, j. 24.10.2002, voto do Min. Sepúlveda Pertence, p. 46.

${ }^{224}$ PAOLA, Leonardo Sperb de. Presunções e ficções no direito tributário. Belo Horizonte: Del Rey, 1997, p. 159-160. 
esses limites contam-se a observância do princípio da proibição ao excesso no recurso à tipificação, a exigência de esta assentar em critérios de natureza objectiva e a imposição da previsão de medidas equitativas, que atenuem as iniqüidades ou injustiças graves a que a tipificação, eventualmente, possa conduzir. ${ }^{225}$

Não é outra a opinião de KLAUS TIPKE ao afirmar que "as normas de simplificação, que desconsideram peculiaridades das situações individuais, devem partir da normalidade média(...) devem ser imprescindíveis e eficazes, não lhes sendo permitido privilegiar ou discriminar alguém excessivamente (...) o ganho em praticabilidade não pode ter por consequência um excessivo prejuízo da justiça no caso concreto". ${ }^{226}$

Por isso pode-se concluir que a pretexto de uma padronização, é vedada ao legislador tributário uma tributação desarrazoada, que atinja bens jurídicos essenciais à realização do direito fundamental de propriedade, pela subtração de parcela expressiva do patrimônio do contribuinte.

Como decorrência dessa proibição de excesso, a praticabilidade deve prever cláusulas de ajuste, conforme já foi exposto, que permitam a devolução de tributos cobrados e pagos sem fundamento de validade, como acontece com valores pagos em decorrência de base presumida superior ao valor real da operação, possibilitando o respeito ao princípio de proibição ao efeito de confisco e garantia de convívio harmônico entre o direito de propriedade e a tributação.

${ }_{225}^{25}$ PAOLA, Leonardo Sperb de. Presunções e ficções no direito tributário. Belo Horizonte: Del Rey, 1997, p. 624.

226 TIPKE, Klaus; YAMASHITA, Douglas. Justiça Fiscal e Princípio da Capacidade Contributiva, p. 38-39 


\title{
5.11 Limites à Praticabilidade
}

Concluído o exame da praticabilidade em face dos princípios básicos constitucionais, é possível encerrarmos o presente capítulo, construindo a partir da articulação de tudo o que ficou disperso nas várias considerações, os limites à sua utilização no direito tributário brasileiro.

Inicialmente reafirmamos as premissas de que consideramos a praticabilidade um verdadeiro princípio; e que nenhum princípio aplica-se integralmente num eventual confronto com outros princípios, mas influenciam-se reciprocamente, garantindo-se uma solução harmônica, na qual seja assegurada que todos eles sejam minimamente observados. ${ }^{227}$

Deixamos assentado, por vários motivos apontados durante o desenvolvimento deste estudo, que a praticabilidade tornou-se imprescindível na aplicação e fiscalização de vários tributos, mas não se quer dizer com isso que ela representa uma carta em branco, que o legislador possa utilizar para não observar os princípios e valores fundamentais tão caros em nossa Constituição, ou como enuncia MISABEL DERZI:

\begin{abstract}
De modo algum se nega que o legislador possa criar presunções jurídicas por razões as mais diversificadas (praticidade, prevenção da sonegação, etc.). Mas nunca iuris et de iure, contra o princípio da realidade e da capacidade econômica. $\mathrm{O}$ que se afirma apenas é que, em qualquer caso, seja nas ficções e presunções, seja no estabelecimento de somatórios, pautas, tipos ou conceitos fechados, o legislador tem de ser fiel à Constituição, aos seus valores e princípios. Sua liberdade está restringida por aqueles valores e princípios, sua discricionariedade não se confunde com o arbítrio de um querer qualquer, que não encontra justificação naquelas normas superiores da Constituição. ${ }^{228}$
\end{abstract}

Sobre o perigo da utilização desmedida da praticabilidade, vale a ressalva que "é uma prática que tem limites e não pode ser levada às últimas circunstâncias pela Administração, sob pena de se criar um regime de exceção absoluto em matéria negocial" ${ }_{229}$.

MiSABEL DERZI, apontando a obra de ISENSEE como referência, enumera as seguintes regras e limites a serem observadas pela chamada "tipificação administrativa":

- Retringir-se ao mínimo necessário, proibindo-se os excessos;

\footnotetext{
${ }^{227}$ SCHOUERI, Luís Eduardo. Direito Tributário. São Paulo: Saraiva, 2011, p. 265.

228 DERZI, Misabel De Abreu Machado. Direito tributário, direito penal e tipo, 2. ed. São Paulo: Revista dos Tribunais, 2008. p. 362.

229 TÔRRES, Heleno Taveira. Direito Tributário e Direito Privado - Autonomia Privada, Simulação, Elusão Tributária. São Paulo: Revista dos Tribunais, 2003, p. 403-404.
} 
- Respeitar os direitos fundamentais, baseando-se em tipos que se formam de acordo com a representação daquilo que for normal;

- Limitar-se a uma tributação pela média dos valores, vedando-se que o método se transforme em instrumento de política fiscal, de redistribuição de renda ou de benefícios e isenções tributárias;

- Estabelecer critérios uniformes que não podem variar de repartição para repartição;

- Ficar pautas de valores, somatórios ou presunções que devem obrigar a própria Administração, a qual, por imperativo do Estado de Direito, não pode deles se afastar;

- Dar ampla publicidade aos padrões, esquemas e pautas de valores, os quais não podem constar de orientações internas secretas. ${ }^{230}$

Podemos acrescentar ainda como limites, em face da ponderação com os demais princípios constitucionais: (i) obediência à repartição constitucional de competências; (ii) seja demonstrada a necessidade da medida, em razão da deficiência administrativa, ou seja, a supressão da simplificação implicaria um aumento desproporcionado dos custos de gestão, repercutindo-se em prejuízo de todos; (iii) que o valor padrão reflita verdadeiramente a média, ou a normalidade das situações fáticas, aproximando o máximo possível da real capacidade econômica dos contribuintes; (iv) que a padronização seja justificada por manter uma relação de razoabilidade com a média dos casos alcançados pela tributação; (v) sejam previstas cláusulas de equidade, que possibilitem a correção das distorções entre o valor padrão e o valor real, com a respectiva devolução do tributo pago a maior; (vi) o regime simplificado deverá ser opcional facultando aos contribuintes sujeitar-se ou não a tais regimes, segundo aquilo que entender mais proveitoso; e (viii) respeito aos direitos e princípios constitucionais buscandose sempre a convivência harmônica entre esses princípios e a praticabilidade, de formar a que seja alcançada a almejada justiça fiscal.

${ }^{230}$ DeRZI, Misabel de Abreu Machado. Direito tributário, direito penal e tipo, 2. ed. São Paulo: Revista dos Tribunais, 2008. p. 341. 


\section{Estudo de Casos}

Cabe, neste momento, analisarmos alguns diplomas normativos que revelam uma aplicação do princípio da praticabilidade no direito tributário brasileiro pelo legislador infraconstitucional, mediante uma apreciação criteriosa de sua utilização como métodos empregados pelo Executivo para simplificar a execução da lei de forma ampla e sistemática, garantindo sua aplicabilidade a milhares de casos.

Essa análise crítica demandará sempre uma ponderação entre a praticabilidade e os demais princípios que emolduram a atividade tributante no nosso ordenamento, trazendo à luz as mais recentes soluções jurisprudenciais.

Desprovidos da pretensão de analisar todos os comandos legais, nos quais se inserem ponderações do princípio da praticabilidade, visto que tal empresa seria impraticável e frustrante, optamos estudar algumas normas que julgamos mais emblemáticas do ponto de vista da aplicação e fiscalização, focando nossa análise, principalmente, nas simplificações que viabilizaram sua execução em grande escala, a despeito das deficiências da máquina administrativa para sua gestão.

\subsection{Planta Genérica de Valores}

A Constituição Federal de 1988, no artigo 156, I', outorgou a competência tributária aos munícipios para a criação do imposto sobre propriedade predial e territorial urbana.

O Código Tributário Nacional² erigiu, com base no arquétipo constitucional do IPTU, o núcleo da hipótese de incidência: como sendo a propriedade, o domínio útil ou a posse de bem imóvel por natureza ou por acessão física, e por base de cálculo: o valor venal do imóvel.

\footnotetext{
${ }^{1} \mathrm{CF} / 88$.Art. 156. Compete aos Municípios instituir impostos sobre: I - propriedade predial e territorial urbana; [...]

${ }^{2}$ CTN. Art. 32. O imposto, de competência dos Municípios, sobre a propriedade predial e territorial urbana tem como fato gerador a propriedade, o domínio útil ou a posse de bem imóvel por natureza ou por acessão física, como definido na lei civil, localizado na zona urbana do Município.

$\S 1^{\circ}$ Para os efeitos deste imposto, entende-se como zona urbana a definida em lei municipal; observado o requisito mínimo da existência de melhoramentos indicados em pelo menos 2 (dois) dos incisos seguintes, construídos ou mantidos pelo Poder Público:

I - meio-fio ou calçamento, com canalização de águas pluviais;

II - abastecimento de água;

III - sistema de esgotos sanitários;

IV - rede de iluminação pública, com ou sem posteamento para distribuição domiciliar;

V - escola primária ou posto de saúde a uma distância máxima de 3 (três) quilômetros do imóvel considerado.
} 
O valor venal do imóvel, base de cálculo do tributo, é “o valor provável que o imóvel atingirá, diante de transação à vista e de mercado imobiliária estável". ${ }^{3}$

Como grande parte dos imóveis não estão sendo negociados, o valor venal nada mais é do que um valor estimativo, teórico e provável. Se o valor efetivo da base de cálculo do tributo só será obtido a posteriori, não é possível à lei estabelecer previamente seu valor.

As formas possíveis de avaliação são: “a) proceder a avaliações individuais, inteiramente a cargo dos agentes tributadores; b) empregar o sistema de avaliação em massa, isto é, proceder a avaliações com lastro em regras e métodos predeterminados, mediante o emprego de pessoal especializado e adrede distribuído nas várias fases do processo" (grifo nosso).$^{4}$

A primeira forma avaliativa traz a vantagem da apuração individual de cada imóvel, mas, por outro lado, o subjetivismo e a discricionariedade do agente fiscal no ato do lançamento, além da demanda enorme de recursos humanos e financeiros para tal empreitada, sinalizam embargos à sua utilização.

Ficamos com entendimento majoritário da doutrina que a subjetividade inerente ao primeiro método é mais danosa do que eventuais distorções, que um sistema impessoal de avaliação em massa proporcionaria.

GERALDO ATALIBA assim se posicionou sobre a questão: "Esta forma de proceder é mais requintada, mais objetiva, mais racional e mais consentânea com as exigências do Estado de Direito e do princípio da estrita legalidade da tributação, pois retira qualquer desenvoltura, subjetivismo ou pessoalidade do lançamento".5

Acompanhando este raciocínio, a manifestação de AIRES BARRETO: "Daí, sem embargo de liberalidade do Código Tributário Nacional quanto aos critérios de obtenção de valores venais, conclui-se que o ideal é o cerceamento, por lei municipal, do comportamento das autoridades administrativas, através da imposição de regras e métodos genéricos e impessoais". ${ }^{6}$

$\S 2^{\circ}$ A lei municipal pode considerar urbanas as áreas urbanizáveis, ou de expansão urbana, constantes de loteamentos aprovados pelos órgãos competentes, destinados à habitação, à indústria ou ao comércio, mesmo que localizados fora das zonas definidas nos termos do parágrafo anterior.

Art. 33. A base do cálculo do imposto é o valor venal do imóvel.

Parágrafo único. Na determinação da base de cálculo, não se considera o valor dos bens móveis mantidos, em caráter permanente ou temporário, no imóvel, para efeito de sua utilização, exploração, aformoseamento ou comodidade.

${ }^{3}$ BARRETO, Aires Fernandino. Curso de Direito Tributário Municipal. São Paulo: Saraiva, 2009, p. 209.

${ }^{4}$ Ibidem, p. 209. O autor ressalta que "do ângulo legal, não há restrições aos métodos e processos técnicos que se venham a empregar, sendo ambas as hipóteses irrepreensíveis, posto constitucionais, consentâneas com o CTN e com a natureza do tributo". Ibidem, p. 209.

${ }^{5}$ ATALIBA, Geraldo. Imposto predial e taxas de serviços urbanos. Revista de Direito Público. n. 11. São Paulo: Revista do Tribunais, jan./mar. 1979, p. 122-123.

${ }^{6}$ BARRETO, Aires Fernandino. Curso de Direito Tributário Municipal. São Paulo: Saraiva, 2009, p. 210. 
Como forma de apuração do valor venal e, por conseguinte, da base de cálculo do imposto, livre de subjetivismo e arbítrio, o Executivo utiliza como técnica avaliativa presuntiva as Plantas Genéricas de Valores - PGV, ou Planta Fiscal do IPTU, ou ainda Mapa de Valores Genéricos ${ }^{7}$ que podem ser definidos como:

O complexo de plantas, tabelas, listas, fatores e índices determinantes dos valores médios unitários de metro quadrado (ou linear) de terreno e de construção, originários ou corrigidos, acompanhados de regras e métodos, genéricos ou específicos, para a apuração do valor venal de imóveis. ${ }^{8}$

A elaboração das Plantas Genéricas de Valores é regulamentada pelo Comitê Brasileiro de Construção Civil, pela NBR - 14.653-29 (Avaliação de Imóveis Urbanos da ABNT - Associação Brasileira de Normas Técnicas).

O método de avaliação em massa pela Planta Genérica de Valores é extremamente complexo. ${ }^{10}$ Para os terrenos leva-se em conta sua área e fatores corretivos como localização, forma, depreciação, aproveitamento, entre outros; e para os imóveis construídos considera-se a área construída, valores do metro quadrado de construção por tipo-padrão (residências horizontais, apartamentos, lojas etc.) além de outros fatores de correção previstos tais como: número de unidades em condomínio, obsolescência etc.

Como norma presuntiva, a PGV está a serviço da praticabilidade, cumprindo a função de simplificar a execução da lei e, ainda que eventuais discrepâncias possam surgir em razão da impossibilidade prática da avaliação individual, concordamos com a conclusão de que "revela-se aconselhável: facilita e racionaliza o trabalho, resguarda a necessária uniformidade no comportamento do Fisco, evita discrepâncias próprias do arbítrio e representa segurança para o Fisco e os contribuintes". ${ }^{11}$

Segundo MiSABEL DERZI, esses mapas de valores "atendem não só a necessidade de racionalização e simplificação do trabalho de execução da lei, como uniformizam o

\footnotetext{
${ }^{7}$ Aires Barreto justifica a expressão Mapas de Valores Genéricos ao invés de Plantas Genéricas de Valores: "Há de ter o leitor observado que mencionamos, desde o início, 'Plantas Genéricas de Valores', expressão que temos usado ao longo do tempo, porque, como diz o provérbio popular: 'O uso do cachimbo faz a boca torta'. Todavia, à medida que meditamos sobre a expressão, fomos corrigindo-a, pouco a pouco. Inicialmente, verificamos que o termo 'Plantas' é menos amplo que 'Mapas', sobretudo por não conter a significação de tabelas, listas, róis etc., abrangida por este último. Recentemente, fomos mais longe. Concluímos pela impropriedade de falar em 'Plantas Genéricas' ou mesmo ‘Mapas Genéricos', porque na verdade não são as 'Plantas' ou os 'Mapas' que são genéricos, mas sim os valores de metro quadrado que estampam. Daí nosso entendimento de a expressão correta ser 'Mapas de Valores Genéricos'. BARRETO, Aires Fernandino. Curso de Direito Tributário Municipal. São Paulo: Saraiva, 2009, p. 227.

${ }^{8}$ Ibidem, p. 227.

${ }^{9}$ Esta Norma define: "Planta de valores é a representação gráfica ou listagem dos valores genéricos de metro quadrado de terreno ou do imóvel numa mesma data".

${ }^{10}$ Em razão desta complexidade Aires Barreto adverte que "é aconselhável, na determinação de ditos valores, estabeleça-se ligeira diferença, para menor, em relação aos valores de mercado, constituindo 'faixa de segurança'. BARRETO, Aires Fernandino. Curso de Direito Tributário Municipal. São Paulo: Saraiva, 2009, p. 230.

${ }^{11}$ BARRETO, Aires Fernandino. Curso de Direito Tributário Municipal. São Paulo: Saraiva, 2009, p. 227.
} 
tratamento fiscal da matéria, impedindo que critérios díspares e injustos sejam adotados pelos agentes fiscais lançadores do imposto". ${ }^{12}$

Importa ainda destacar, como AIRES BARRETO ${ }^{13}$, que a planta genérica de valores é ato administrativo, infralegal e que em nada inova a ordem jurídica. Com o objetivo de determinar a apuração de modo padronizado do valor venal de cada imóvel, não afeta a base imponível fixada em lei e nem se confunde com a base calculada. Limita-se a ser ato declaratório de valores já existentes, utilizados como um dos elementos necessários à apuração do valor venal, na apreciação de cada caso individualmente considerado.

Não há na jurisprudência questionamentos recentes quanto à utilização da PGV pelo Executivo, como método de simplificação e aplicação da lei do IPTU. Os julgados recentes versam principalmente sobre a necessidade de lei formal para atualização dos valores imobiliários, que não se restrinjam aos índices de correção monetária.

Segundo a jurisprudência do STJ, o aumento da base de cálculo depende da elaboração de lei, conforme entendimento consolidado na Súmula 160:

É defeso ao município atualizar o IPTU, mediante decreto, em percentual superior ao índice oficial de correção monetária.

Como exemplo deste entendimento, a Segunda Turma do STJ decidiu por negar recurso ao município de Bom Sucesso (MG), que aumentou a base de cálculo do IPTU por meio de decreto. A ementa dessa decisão ${ }^{14}$, repetida em muitas outras, traduz:

1.Nos termos da jurisprudência pacífica desta Corte, a majoração da base de cálculo do IPTU depende da elaboração de lei, não podendo um simples decreto atualizar o valor venal dos imóveis sobre os quais incide tal imposto com base em uma planta de valores, salvo no caso de simples correção monetária.

2. Não há que se confundir a simples atualização monetária da base de cálculo do imposto com a majoração da própria base de cálculo.

De acordo com o relator, Ministro Humberto Martins, mesmo que o Código Tributário Municipal traga critérios de correção dos valores venais dos imóveis, o município não está autorizado a majorar os valores sem a participação do Pode Legislativo local.

\footnotetext{
${ }^{12}$ DERZI, Misabel de Abreu Machado. Direito tributário, direito penal e tipo, 2. ed. São Paulo: Revista dos Tribunais, 2008. p. 348.

${ }^{13}$ BARRETO, Aires Fernandino. Curso de Direito Tributário Municipal. São Paulo: Saraiva, 2009, p. 227.

${ }^{14}$ STJ, AgRg no Agravo em Recurso Especial n ${ }^{\circ}$ 66.849/MG (2011/0174910-2), Rel: Min. Humberto Martins, j. 06.12.2011.
} 
Essa também é a posição do Supremo Tribunal Federal, que a partir do pardigmático RE 87.763 - PI ${ }^{15}$, alterou seu entendimento anterior, uniformizando a jurisprudência da Corte, conforme a ementa:

O $\S 2^{\circ}$. do artigo 97 do Código Tribuário Nacional diz respeito, somente, à correção monetária do valor venal do imóvel (base de cálculo do imposto predial), não alcançando a reavaliação mesma (reavaliação econômica) desse valor venal.

Para se atribuir outro valor venal ao imóvel, que não o decorrente do ano anterior mais correção monetária, é mister lei, não bastando para isso simples decreto.

A fundamentação desse entendimento do Poder Judiciário, que não enfoca o ponto fundamental do tema, é na análise de Misabel Derzi ${ }^{16}$ passível de críticas.

Na doutrina da jurista mineira a avaliação de cada imóvel é aplicação da norma ao caso concreto, que compete exclusivamente ao Executivo (art. 142, CTN) e que não se confunde com o estabelecimento do valor venal de forma abstrata em lei pelo Legislativo. Retirar a avaliação e, portanto, a aplicação da norma pelo Poder Executivo é ferir o princípio da separação dos poderes. ${ }^{17}$

A polêmica central do tema, segunda a professora, que não foi abordada pelo Judiciário, reside na atuação das plantas de valores como presunções, sem que haja a pretendida avaliação individual requerida pela lei, ou em outros termos "o estado de necessidade administrativo leva à formação de padrões e esquemas que atuam como presunções, fixadas pelo Poder Executivo, as quais são um arranhão ao princípio da legalidade tributária". ${ }^{18}$

Este raciocínio baseia-se na suposição que “um considerável número de diferenças individuais constantes do caso isolado concreto são desprezadas"19 e, por conseguinte, “a uniformidade e a simplificação, que as plantas de valores genéricos alcançam, são incompatíveis com a finalidade de justiça individual, legalmente almejada. Tributar cada um segundo a sua capacidade contributiva (a qual varia de propriedade a propriedade imobiliária) e na proporção de sua desigualdade é a meta legal". ${ }^{20}$

\footnotetext{
${ }^{15}$ STF. RE 87.763-1/PI. Rel. Min. Moreira Alves, DJU 23.11.1979.

${ }^{16}$ DERZI, Misabel De Abreu MACHADO. Direito tributário, direito penal e tipo, 2. ed. São Paulo: Revista dos Tribunais, 2008. p. 345-347.

17 "Encontrar o valor venal de cada imóvel em particular, em cada caso concreto, é aplicar a norma, reduzindo-a ao individual e concreto. Ato que não é da competência do Poder Legislativo, mas do Poder Executivo, por meio da realização do lançamento. Ato que se dá no mundo do ser". DERZI, Misabel de Abreu Machado. Direito tributário, direito penal e tipo, 2. ed. São Paulo: Revista dos Tribunais, 2008. p. 346.

${ }^{18}$ DERZI, Misabel De Abreu Machado. Direito tributário, direito penal e tipo, 2. ed. São Paulo: Revista dos Tribunais, 2008. p. 351.

${ }^{19}$ DERZI, Misabel de Abreu Machado. Direito tributário, direito penal e tipo, 2. ed. São Paulo: Revista dos Tribunais, 2008. p. 349.

${ }^{20}$ DERZI, Misabel de Abreu Machado. Direito tributário, direito penal e tipo, 2. ed. São Paulo: Revista dos Tribunais, 2008. p. 349.
} 
Já deixamos claro, no desenvolvimento deste trabalho, que nossa posição não é esta. Pela praticabilidade, o legislador faz a opção de realização eficiente de uma igualdade geral como o fim desejado, embora simplificação e economia sejam consequências desejadas. Pela escolha de um padrão, como no caso a planta genérica de valores, não se abandona o princípio da igualdade e a capacidade contributiva, só se modifica o seu espectro de concretização: ao invés de uma justiça individual deficitária, realiza-se uma justiça geral, considerando-se elementos que presumidamente estejam na imensa maioria dos casos.

Se o número de discrepâncias entre o valor presumido e o valor real for significativo, como aponta DERZI, é porque o padrão é inviável e não a tributação padronizada.

Destacamos um trecho do voto do relator Ministro Moreira Alves que julgamos fundamental para este tema ${ }^{21}$ :

\footnotetext{
Observo, por fim, que o argumento pragmático de que a exigência de lei para a reavaliação do valor venal dos imóveis seria irrealizável, ou, pelo menos, dificultada em extremo, não tem procedência.

O caso dos autos o demonstra inequivocamente. A fixação dos novos valores do metro quadro conforme o local do terreno e a qualidade da construção não se faz imóvel por imóvel, mas com base em critérios gerais que atendem às diferenças de localização e de qualidade, e critérios esses que podem, perfeitamente, ser estabelecidos por lei. Tanto assim que o foram por Decreto. (Grifo nosso)
}

Pode-se inferir por este trecho do voto, que o entendimento da jurisprudência firmada no Supremo Tribunal Federal, pelo mencionado RE 87.763-1/PI, é pela possibilidade da administração estabelecer presunções para aplicação do IPTU, ao admitir que a fixação de valores não se faz imóvel a imóvel, mas com base em critérios gerais, com a ressalva de que a majoração em termos reais só será admitida por lei formal, ponderando de forma harmônica os princípios da praticabilidade com a legalidade e segurança jurídica.

Este também é o entendimento do Superior Tribunal de Justiça, que em recente decisão da Segunda Turma, proveu recurso do município de São Paulo, reformando acórdão do Tribunal de Justiça de São Paulo, que havia acolhido pedido de uma contribuinte para determinar que a base de cálculo do ITBI fosse exatamente a mesma do IPTU, geralmente defasada em relação à realidade do mercado.

Em seu voto, o Ministro Relator Herman Benjamin, deixa claro a imprescindibilidade das Plantas Genéricas de Valores, para viabilizar a cobrança do IPTU22:

\footnotetext{
${ }^{21}$ STF. RE 87.763-1/PI. Rel. Min. Moreira Alves, DJU 23.11.1979.

${ }^{22}$ STJ. REsp 1.199.964/ SP. Rel. Min. Herman Benjamin, DJe 23.10.2013.
} 
[...]os Municípios lançam o imposto sobre propriedade de ofício e, para viabilizar a cobrança, acabam adotando fórmulas genéricas que abarcam os milhares e, no caso de São Paulo, milhões de imóveis tributados anualmente.

Refiro-me às famosas plantas genéricas de valores que, exatamente por serem avaliações unilaterais do valor venal desses bens, devem ser veiculadas por lei.

Seria absurdo imaginar que o Município de São Paulo avaliasse individualmente cada um dos milhões de imóveis urbanos existentes em seu território para lançar anualmente o IPTU de ofício, daí a adoção das plantas genéricas.

Por fim, queremos destacar que é imprescindível pelo princípio da razoabilidade, conforme expusemos anteriormente, que a base presuntiva mantenha vinculação com a realidade, possibilitando sempre comprovar a correspondência entre o padrão e o valor médio efetivo.

No caso da planta fiscal de valores, tal vinculação está baseada numa pesquisa minuciosa dos preços dos imóveis e que as atualizações sejam frequentes. Assim procedendo o princípio da capacidade contributiva concreta será melhor atendido, bem como os princípios da publicidade e do devido processo legal, que possibilitarão o controle e a adoção de medidas impugnativas ao lançamento abusivo.

AIRES BARRETO sugere que "sendo ânuo o lançamento do IPTU, o ideal é que os Mapas também o sejam"²3 e adverte que sem atualização "surgem e logo se acentuam as discrepâncias, e os Mapas deixam de atender sua missão". ${ }^{24}$

Ocorre que a jurisprudência não aceita o reajuste real das plantas genéricas de valores por ato do Executivo, o que na prática implica complexos projetos de lei, de longa tramitação e discussão política. Essas demandas inviabilizam, principalmente nas grandes cidades, o reajuste anual, de modo que a defasagem em relação à real avaliação dos imóveis urbanos acaba aumentada a cada ano que passa

Como exemplo, neste ano de 2013, vários munícipios atualizaram as plantas genéricas de valores que estavam defasados em cerca de dez anos. Este atraso na atualização dos valores acarretou em aumentos, em alguns casos, na ordem de $2000 \%{ }^{25}$ !

\footnotetext{
${ }^{23}$ BARRETO, Aires Fernandino. Curso de Direito Tributário Municipal. São Paulo: Saraiva, 2009, p. 241.

${ }^{24}$ Ibidem, p. 241.

${ }^{25}$ D’Agostino, Rosanne. Prefeituras revisam planta de municípios e inflacionam IPTU. São Paulo: G1, 2013. Disponível em < http://m.g1.globo.com/brasil/noticia/2013/01/prefeituras-revisam-planta-de-municipios-e-inflacionam-iptu.html>. Acesso em: 1 maio 2013.
} 
Como o valor venal com base na planta genérica de valores é presunção relativa ${ }^{26}$, sempre assiste ao contribuinte o direito de impugnar o lançamento com base em prova em contrário, nos termos do art. 148 do $\mathrm{CTN}^{27}$, seja no âmbito administrativo, seja no judicial.

\footnotetext{
${ }^{26}$ Assim a doutrina: "Finalmente, entendemos que as plantas deverão ser consideradas ficções jurídicas caso haja uma completa discrepância entre os valores nelas contemplados e os que provavelmente corresponderiam à realidade. Nessa hipótese, não poderão, nem diante de inércia do contribuinte, ser utilizadas como índices para a quantificação da base de cálculo, por ferir a razoabilidade, proporcionalidade e possuir efeitos confiscatórios". FERRAGUT, Maria Rita. Presunções no direito tributário. São Paulo: Dialética, 2001, p. 136. No mesmo sentido: “A base de cálculo pautada nas pesquisas da ABNT e do IBAPE deverá ser sempre igual ou inferior àquela que realmente acontece, nunca o contrário. $\mathrm{O}$ excedente é tributação fictícia, e não presumida, pois parte daquilo que não é para arrecadar. Esse valor pago a maior é, pois, ficção, logo, é tributo inconstitucional e indevido. O princípio da praticabilidade arrecadatória não deve nunca sobrepor-se aos direitos fundamentais do contribuinte, constitucionalmente protegidos. O direito à prova em contrário é garantia constitucional, podendo e devendo ser exercido a qualquer tempo". HARET, Florence. Teoria e Prática das Presunções no Direito Tributário. São Paulo: Noeses, 2011, p. 698. ${ }^{27}$ Art. 148, CTN. Quando o cálculo do tributo tenha por base, ou tome em consideração, o valor ou preço de bens direitos, serviços ou atos jurídicos, a autoridade lançadora, mediante processo regular, arbitrará aquele valor ou preço, sempre que sejam omissos ou não mereçam fé as declarações ou os esclarecimentos prestados, ou os documentos expedidos pelo sujeito passivo ou pelo terceiro legalmente obrigado, ressalvada em caso de contestação, avaliação contraditória, administrativa ou judicial.
} 


\title{
6.2 Pautas Fiscais
}

A expressão pauta fiscal serve para designar qualquer lista ou relação de valores publicados e utilizados pela administração fazendária como referência na determinação da base de cálculo dos tributos. São considerados como pautas fiscais, por exemplo: a tabela de veículos usados para o IPVA; lista de produtos sujeitos à taxa de importação; valores pré-fixados de base de cálculo no ICMS e IPI; bases de cálculo presumidas nas operações sujeitas ao regime de substituição tributária etc. Segundo a doutrina constitui-se como forma de:

[...] fixação, pelo sujeito ativo da obrigação tributária, de um valor pré-fixado da operação, tomado como teto, independentemente do efetivo valor da operação, divergindo, de um para o outro desses sujeitos, o rol das mercadorias às quais este valor é atribuído. ${ }^{28}$

As pautas fiscais, que ora nos propomos analisar, representam um expediente muito utilizado pela administração fiscal que preestabelece um valor mínimo de base de cálculo na operação, independentemente do valor efetivo.

Estas pautas fiscais, que atuam como limites mínimos de preços fixados pela autoridade competente, diferenciam-se do arbitramento ${ }^{29}$ por estarem previstas na própria lei instituidora do tributo e por não apresentarem caráter sancionatório.

No julgado do RExt n. 78.577/SP, o STF demonstra o entendimento de que a pauta fiscal não se configura como sanção e, por ser valor presumido, pode implicar em alguns casos um valor de tributo maior a ser recolhido. Contudo, comprovado o preço real da operação ${ }^{30}$, não poderá prevalecer a presunção da pauta fiscal. Senão, vejamos a ementa ${ }^{31}$ :

\begin{abstract}
A base de cálculo do ICM é o valor da operação de que decorrer a saída da mercadoria (art. $2^{\circ}$., I, do Dl. 406, de 1968). Não é lícito ao legislador estadual inovar quanto a esse aspecto (art. 18, § $1^{\circ}$., da E.C. 1, de 1969). A predeterminação de valor para as operações pode contrariar essa disposição, implicando, por outro lado, em majoração do imposto (art. 97, $\S 1^{\circ}$., do CTN).
\end{abstract}

\footnotetext{
${ }^{28}$ ROCHA, Valdir de Oliveira (Coord.). Grandes questões atuais do direito tributário. São Paulo: Dialética, 2005, v.9, p. 106. ${ }^{29}$ Assim a doutrina: "Em sentido estrito e em oposição à pauta fiscal decantada acima, o arbitramento surge no enunciado do art. 148 do CTN. Sempre que sejam omissos ou não mereçam fé as declarações, os esclarecimentos prestados ou os documentos expedidos pelo sujeito passivo, ou pelo terceiro obrigado, a autoridade fiscal poderá arbitrar, mediante processo regular, valor ou preço de bens, direitos, serviços ou atos jurídicos. Ora, omissão ou não merecimento de fé são causas juridicizadas que dão ensejo ao arbitramento. Logo, o fato antecedente que faz admitir a técnica do arbitramento é da ordem da ilicitude. Ausentes as condutas ilícitas, é vedado arbitrar". HARET, Florence. Teoria e Prática das Presunções no Direito Tributário. São Paulo: Noeses, 2011, p. 208. Com o mesmo entendimento: "A legislação fiscal emprega o vocábulo arbitramento em basicamente três acepções: ato administrativo de apuração de base de cálculo concretizado por meio de métodos indiciários; definição legal de base de cálculo substitutiva; e ato administrativo decorrente da impossibilidade de adoção da base de cálculo substitutiva. Em todas elas, a presença do ilícito é fundamental para a investigação ora proposta, o que afasta os demais 'arbitramentos' de base de cálculo, relativos às presunções criadas com fundamentos no princípio da praticabilidade (lucro presumido, plantas fiscais de valores etc.)”. FERRAGUT, Maria Rita. Presunções no direito tributário. São Paulo: Dialética, 2001, p. 137.

${ }^{30}$ A doutrina também firma o entendimento de que: "A utilização de pautas, portanto, só pode ocorrer se a prova direta não puder ser produzida, quando então transformar-se-á em regra que contempla valores para o arbitramento da base de cálculo". FERRAGUT, Maria Rita. Presunções no direito tributário. São Paulo: Dialética, 2001, p. 135.

${ }^{31}$ STF, RExt 78.577/SP, 6a. Seção, DOU 02.04.1975, Rel. Min. Cordeiro Guerra.
} 
Aplicação do art. 148 do CTN. A pauta fiscal só se legitima quando, em processo regular, não ficar demonstrado o valor real da operação de que decorrer a saída da mercadoria.

O art. 30 da lei 6.374/89 que instituiu o ICMS no estado de São Paulo prevê a pauta fiscal como um valor mínimo para a comercialização de mercadorias ou prestação de serviços:

Artigo 30 - O valor mínimo das operações ou prestações poderá ser fixado em pauta expedida pela Secretaria da Fazenda.

$\S 1^{\circ}$ - A pauta poderá ser modificada a qualquer tempo, para inclusão ou exclusão de mercadoria ou serviço.

$\S 2^{\circ}$ - A pauta poderá ser aplicada em uma ou mais regiões do Estado, tendo em conta categorias, grupos ou setores de atividades econômicas, e ter seu valor atualizado sempre que necessário.

$\S 3^{\circ}$ - Havendo discordância em relação ao valor fixado, caberá ao contribuinte comprovar a exatidão do valor por ele declarado, que prevalecerá como base de cálculo.

$\S 4^{\circ}$ - Nas operações ou prestações interestaduais, a aplicação do disposto neste artigo dependerá de celebração de acordo entre os envolvidos, Estados ou Distritos Federal, para estabelecer os critérios de fixação dos valores.

As pautas fiscais em São Paulo estavam sendo utilizadas, principalmente, nas operações com gado em pé e produtos resultantes da matança, conforme previsão do art. 365 do Regulamento do ICMS (RICMS - Decreto 45.590/00):

Artigo 366 - A base de cálculo do imposto é (Lei 6.374/89, art. 24, na redação da Lei $10.619 / 00$, art. $1^{\circ}$, XIII, e 30):

I - nas hipóteses do artigo 364 e do inciso I do artigo 365, o valor da operação, na forma prevista neste regulamento.

II - na hipótese do inciso II do artigo 365, o valor da operação de que tiver decorrido a entrada do gado em pé no estabelecimento abatedor, na forma prevista neste regulamento.

Parágrafo único - O valor mínimo da operação poderá ser fixado em pauta fiscal, nos termos do artigo 46.

A tabela de valores prefixados das bases de cálculo está regulamentada na Portaria

CAT No.97/2012 32 :

32 TABELA DE VALORES A QUE SE REFERE A PORTARIA CAT- 97/2012

I - GADO EM CONDIÇÕES DE ABATE

\begin{tabular}{|l|l|l|}
\hline D i s c r i m i n a ç ã o & Unidade & Valor - R\$ \\
\hline Boi & Cabeça & $1.547,00$ \\
\hline Novilho Precoce & Cabeça & $1.365,00$ \\
\hline Búfalo & Cabeça & $1.136,00$ \\
\hline Búfalo Precoce & Cabeça & $1.065,00$ \\
\hline$[\ldots]$ & {$[\ldots]$} & {$[\ldots]$} \\
\hline
\end{tabular}


Artigo $1^{\circ}$ - O Imposto sobre Operações Relativas à Circulação de Mercadorias e sobre Prestação de Serviços de Transporte Intermunicipal e de Comunicação - ICMS, incidente sobre as operações efetuadas com gado e carne, deverá ser calculado sobre os valores fixados na pauta anexa.

Parágrafo único - O imposto será calculado sobre o valor da operação, quando este for superior ao mínimo fixado em pauta.

Entretanto a jurisprudência pacífica do STJ é pela impossibilidade da fixação da base de cálculo por intermédio de pautas fiscais. A propósito os seguintes julgados:

TRIBUTÁRIO. RECURSO ORDINÁRIO EM MANDADO DE SEGURANÇA. ICMS. PRODUTOS FARMACÊUTICOS. BASE DE CÁLCULO. PAUTA FISCAL. IMPOSSIBILIDADE. PRECEDENTES.

1. É inadmissível a fixação da base de cálculo de ICMS com supedâneo em pautas de preços ou valores, as chamadas pautas fiscais, as quais se baseiam em valores fixados prévia e aleatoriamente para a apuração da base de cálculo do tributo, consoante entendimento pacífico desta Corte. Precedentes: RMS n.18.634/MT, Rel. Min. Denise Arruda, Primeira Turma, DJ de 20.09.2007; EDcl no RMS n. 16.810/PA, Rel. Min. Luiz Fux, Primeira Turma, DJ de 04.06.2007; RMS n. 23.502/SE, desta Relatoria, Primeira Turma, DJ de 19.04.2007; RMS n. 19.026/MT,Rel. Min. João Otávio de Noronha, Segunda Turma, DJ de 06.03.2006.

2. Recurso provido. ${ }^{33}$

TRIBUTÁRIO. RECURSO EM MANDADO DE SEGURANÇA. ICMS. BASE DE CÁLCULO. APURAÇÃO POR VALORES FIXADOS EM REGIME DE PAUTA FISCAL. ILEGALIDADE.

1. A jurisprudência do Superior Tribunal de Justiça consolidou-se no sentido da ilegalidade de cobrança do ICMS com base em regime de pauta fiscal.

2. O art. 148 do CTN somente pode ser invocado para a determinação da base de cálculo do tributo quando, certa a ocorrência do fato imponível, o valor ou preço de bens, direitos, serviços ou atos jurídicos registrados pelo contribuinte não mereçam fé, ficando a Fazenda Pública, nesse caso, autorizada a proceder ao arbitramento mediante processo administrativo-fiscal regular, assegurados o contraditório e a ampla defesa (RMS n.18.677-MT, relator Ministro CASTRO MEIRA, DJ de 20.6.2005).

3. Recurso ordinário provido ${ }^{34}$.

Recentemente (DJe 13/05/2010), o STJ consolidou este entendimento pela súmula n. 431:

É ilegal a cobrança de ICMS com base no valor da mercadoria submetido ao regime de pauta fiscal.

\footnotetext{
${ }^{33}$ STJ, RMS 25.605/SE, Rel. Min. José Delgado, Primeira Turma, julgado em 22.4.2008, DJ 21.5.2008.

${ }^{34}$ STJ, RMS 19.026/MT, Rel. Min. João Otávio de Noronha, Segunda Turma, julgado em 15.12.2005, DJ 6.3.2006.
} 
Assim a jurisprudência da alta Corte veda a cobrança do ICMS sobre base fixada em pautas fiscais nas operações normais de compra e venda de mercadorias, excepcionando a fixação de base de cálculo pelo arbitramento, nos casos de cometimento de ilícito, ou desídia pelo contribuinte, como prevê o art. 148 do CTN.

Na legislação do IPI, lei no ${ }^{\circ}$ 7798/89, há também a previsão de utilização de pautas

fiscais:

Art. $3^{\circ} \mathrm{O}$ Poder Executivo poderá, em relação a outros produtos dos capítulos 21 e 22 da TIPI, aprovada pelo Decreto $n^{\circ} 97.410$, de 23 de dezembro de 1988, estabelecer classes de valores correspondentes ao IPI a ser pago.

$\S 1^{\circ}$. Os valores de cada classe deverão corresponder ao que resultaria da aplicação da alíquota a que o produto estiver sujeito na TIPI, sobre o valor tributável numa operação normal de venda.

$\S 2^{\circ}$. As classes serão estabelecidas tendo em vista a espécie do produto, capacidade e natureza do recipiente.

$\S 3^{\circ}$. Para efeitos de classificação dos produtos nos termos de que trata este artigo, não haverá distinção entre os da mesma espécie, com a mesma capacidade e natureza do recipiente.

$\S 4^{\circ}$. Os valores estabelecidos para cada classe serão reajustados automaticamente nos mesmos índices do BTN ou, tratando-se de produtos de preço de venda controlado por órgão do Poder Executivo, nos mesmos índices e na mesma data de vigência do reajuste.

$\S 5^{\circ}$ O Poder Executivo, sempre que, em face do comportamento do mercado na comercialização do produto, julgar necessário, poderá:

a) aumentar, até sessenta por cento, os valores de cada classe, reajustados na forma do parágrafo anterior;

b) manter, temporariamente, o valor do imposto, ainda que alterado o do BTN.

Essa possibilidade de pauta fiscal no IPI já foi apreciada pelo TRF da $4^{\mathrm{a}}$. Região, que se manifestou pela inconstitucionalidade de sua utilização, ao desconsiderar o preço efetivo na operação praticada. Vejamos a ementa do acórdão:

\section{TRIBUTÁRIO. IPI. BASE DE CÁLCULO. VALORES PRÉ-FIXADOS PARA O CÁLCULO DO IPI. INCONSTITUCIONALIDADE.}

A adoção de "pautas fiscais", contendo valores pré-fixados para o cálculo do IPI, desconsidera, na prática, o preço da operação de saída dos produtos. Esta circunstância afronta os arts. 146, III, "a" da Constituição e 47, II, "a", do CTN. Precedente (TRF4, INAC n ${ }^{\circ}$ 2003.71.12.002280-6/RS, Corte Especial, Rel. Des. Federal Antônio Albino de Oliveira. D.E. $\left.n^{\circ} 13.08 .07\right)^{35}$.

A ementa do precedente desta decisão trazia de forma clara o entendimento daquele tribunal, que o valor da operação, como previsto no art. 47 do CTN, é o preço transacionado na operação de compra e venda e não um valor prefixado pelo ente tributante: 
1 - $\mathrm{O}$ art. $3^{\circ}$ da Lei $n^{\circ} 7.798 / 89$, que possibilitou que o Poder Executivo estabeleça, para determinados, a tributação por classes, conflita com os arts. 146, III, "a" da Constituição e 47, II, "a", do CTN.

2 - O art. 47 do CTN utiliza a expressão "valor da operação", que corresponde ao preço do produto enquanto elemento do contrato de compra e venda. Não se trata apenas de um elemento referencial para o poder tributante, mas de definição clara e precisa da base de cálculo do tributo, a qual a lei ordinária não pode desbordar ${ }^{36}$.

A União interpôs Recurso Extraordinário contra este acórdão, defendendo a constitucionalidade deste artigo, alegando em síntese que:

A base de cálculo do IPI, nos termos do art. 146, III, letra a, já foi definida na lei complementar. É o art. 47, inciso II, letra a do CTN, a dizer qual a base de cálculo do IPI: 'valor da operação de que decorrer a saída da mercadoria'. Chama-se a atenção aqui para um conceito-chave: o valor da operação.

$\mathrm{O}$ art. $3^{\circ}$ da Lei n. ${ }^{\circ} 7.798 / 89$, dentro do molde da lei complementar, define, exclusivamente para fins de IPI, o que é o valor da operação, de sorte a integrar e preencher o conteúdo daquele conceito previsto pela lei complementar.

Observa-se, portanto, que a base de cálculo do imposto já foi definida pela lei qualificada como complementar (art. 47, inciso II, letra a do CTN). Com isto cumpriuse o disposto no art. 146, inciso III, letra a da Constituição, pois uma lei complementar efetivamente tratou da base de cálculo de um imposto discriminado na Constituição. ${ }^{37}$

Este recurso ainda não foi julgado, mas já foi reconhecida a existência de repercussão geral, conforme manifestação da Ministra Relatora:

Verifico que a questão possui relevância, porquanto envolve a análise do papel da lei complementar na fixação da base de cálculo dos impostos, em cumprimento ao art. 146, III, a, da CF. Além disso, envolve grande número de contribuintes no País, tendo em conta a dimensão do mercado de bebidas.

Ante o exposto, manifesto-me pela existência de repercussão geral. ${ }^{38}$

Podemos sintetizar que a utilização das pautas fiscais pelo fisco, apesar de representar um mecanismo de simplificação ao fisco no controle da sonegação e evasão fiscal, não está a serviço da praticabilidade.

Ao estabelecer um preço mínimo e não um valor médio das operações efetivamente ocorridas, a administração busca reprimir a sonegação em determinados setores e não viabilizar a aplicação do tributo em massa, chegando ao ponto da fixação da base de cálculo confundirse com arbitramento, sem que tenha ocorrido qualquer ilícito por parte do contribuinte.

\footnotetext{
${ }^{36}$ TRF4, INAC nº 2003.71.12.002280-6/RS, Corte Especial, Rel. Des. Federal Antônio Albino de Oliveira. D.E. nº 13.08.07.

${ }^{37}$ STF, RExt 602917/RS, Rel. Min. Rosa Weber, p. 114.

${ }^{38}$ Disponível em : 〈http://www.stf.jus.br/portal/jurisprudenciaRepercussaoGeral/decisao.asp?decisao=3327293 >. Acesso em 15/setembro/2013.
} 
Tributar acima da medida quantitativa da riqueza estipulada em lei, com base em um valor 'de segurança' para o fisco, é arranhar irremediavelmente os princípios constitucionais da legalidade, igualdade, capacidade contributiva, neutralidade etc., pondo em risco toda a harmonia do sistema jurídico.

Repetimos que padronizar é buscar alcançar a maioria do contribuintes, pressupondo-se que assim consegue-se atingir muito mais igualdade do que um sistema deficiente de verificação individual da capacidade do contribuinte.

No caso em espécie, não houve padronização e nem há fundamento no princípio da praticabilidade. Ao fixar um valor mínimo, perquiriu-se evitar a perda das receitas arrecadatórias em razão da sonegação fiscal e não viabilizar a aplicação do tributo por ser extremamente oneroso ou impraticável sua gestão. Repisemos as palavras de HUMBERTO ÁVILA ${ }^{39}$ :

\begin{abstract}
A padronização só é justificada quando mantém relação de razoabilidade com a média dos casos alcançados pela tributação. Não o fazendo, a padronização perde sua justificação constitucional, que é servir de instrumento para a realização da igualdade geral por meio da correspondência com os elementos concretos manifestados pela média das operações efetivamente praticadas.
\end{abstract}

Andou bem a jurisprudência ao repelir essa prática. Como não há praticabilidade a ser sopesada com a legalidade e capacidade contributiva, estas devem prevalecer como forma de garantia contra o arbítrio e insegurança jurídica.

\footnotetext{
${ }^{39}$ ÁVILA, Humberto. Imposto sobre a circulação de mercadorias: ICMS; substituição tributária; base de cálculo; pauta fiscal; preço máximo ao consumidor; diferença constante entre o preço usualmente praticado e o preço constante da pauta ou o preço máximo ao consumidor sugerido pelo fabricante; exame de constitucionalidade. Revista Dialética de Direito Tributário, n.123. São Paulo: Dialética, 2005, p. 125.
} 


\subsection{Tabela de Veículos Usados no IPVA}

A competência tributária aos Estados e ao Distrito Federal para instituir o imposto sobre propriedade de veículos automotores foi outorgada pela Constituição Federal de 1988, no artigo $155, \mathrm{III}^{40}$.

O Estado de São Paulo com base nessa competência criou o IPVA com a lei $\mathrm{n}^{\circ}$. 6.606/89 que foi revogada pela lei $\mathrm{n}^{\circ}$. 13.296/08 atualmente em vigor.

A base de cálculo está prevista no art. $7^{\circ}$., que dispõe:

Artigo $7^{\circ}$ - A base de cálculo do imposto é:

I - na hipótese dos incisos I, V, IX e X, alíneas "a" e "b", do artigo $3^{\circ}$ desta lei, o valor de mercado do veículo usado constante da tabela de que trata o $\S 1^{\circ}$ deste artigo;

$[\ldots]$

$\S 1^{\circ}$ - Para efeito do disposto no inciso I deste artigo, o Poder Executivo divulgará o valor de mercado por meio de tabela, considerando na sua elaboração a marca, o modelo, a espécie e o ano de fabricação.

$\S 2^{\circ}$ - A tabela a que se refere o $\S 1^{\circ}$ deste artigo, deverá ser divulgada para vigorar no exercício seguinte, e na fixação dos valores serão observados os preços médios de mercado vigentes no mês de setembro.

$\S 3^{\circ}$ - Havendo veículo cujo modelo não tenha sido comercializado no mês de setembro, adotar-se-á o valor de outro do mesmo padrão.

$\S 4^{\circ}$ - O Poder Executivo poderá adotar como base de cálculo:

1 - para o veículo com mais de 10 (dez) anos e até 20 (vinte) anos de fabricação, valor equivalente a $90 \%$ (noventa por cento) da base de cálculo correspondente à do veículo fabricado no ano imediatamente posterior;

2 - para o veículo com mais de 20 (vinte) anos de fabricação, a mesma base de cálculo do veículo com 20 anos de fabricação;

3 - para os veículos usados referidos nos incisos VII e VIII do artigo $3^{\circ}$ desta lei, o valor de registro do veículo novo, depreciado à taxa de $10 \%$ (dez por cento) em relação à base de cálculo utilizada no ano imediatamente anterior.

$\S 5^{\circ}$ - O Poder Executivo poderá firmar convênios ou contratar serviços com entidades especializadas para a pesquisa dos valores médios de mercado dos veículos usados.

$\S 6^{\circ}$ - Para determinação da base de cálculo é irrelevante o estado de conservação do veículo.

$[\ldots]$

$\S 9^{\circ}$ - Nas situações em que for constatada notória redução nos preços médios de mercado vigentes entre o mês de setembro e o mês de dezembro, poderá o Poder Executivo, excepcionalmente, autorizar a redução da base de cálculo. (Grifos nossos)

${ }^{40} \mathrm{CF} / 88$. Art. 155. Compete aos Estados e ao Distrito Federal instituir impostos sobre: [...] III - propriedade de veículos automotores. 
Neste exemplo da legislação paulista, que em muito se assemelha à legislação de outros Estados, pode-se notar uma verdadeira medida simplificadora em consonância com o princípio da praticabilidade, sem a qual tornaria impraticável a aplicação do tributo.

Segundo o DETRAN ${ }^{41}$, o número de veículos automotores no Estado de São Paulo em março de 2013 é de aproximadamente 32.000.000! Não há como imaginar a possibilidade, em face de tal cifra astronômica e crescente, que seria viável à administração fazendária, considerar em cada um dos veículos o estado de conservação, acessórios, tipo de pintura etc., no lançamento do tributo. É imprescindível neste caso, a medida simplificadora padronizante prevista no art. $7^{\circ}$., I, da lei supra mencionada, como forma de viabilizar a aplicação do IPVA nos milhares de contribuintes proprietários de veículos.

A doutrina é pacífica quanto a isto, como podemos notar na seguinte assertiva de MisABEL DERZI:

Podemos exemplificar lembrando-nos do imposto sobre a propriedade de veículos automotores. Duas ou mais pessoas podem possuir carros usados de mesma marca, modelo, ano e capacidade embora cada um deles alcance preço bastante distinto no mercado. O estado de conservação, os acessórios existentes e o desgaste da máquina são fatores que atuam decisivamente, reduzindo ou aumentando o valor venal do veículo. Embora a lei disponha que o valor venal é a base de cálculo do tributo, as diferenças decorrentes desses fatores são ignoradas, havendo a igualação de cada veículo isolado a um modelo normatizado, idealizado, de valor fixo e idêntico, estabelecido em ato administrativo. A imposição fiscal passa a incidir sobre o valor que se presume (iures et iure), segundo pauta estabelecida pelo Poder Executivo e não sobre o valor real do veículo ou aquele que ele, de fato alcança no mercado. ${ }^{42}$

Ou ainda, conforme o posicionamento de MARIA RITA FERRAGUT: ${ }^{43}$

${ }^{41}$ Frota de Veículos em SP - por tipo de veículo

Março 2013
\begin{tabular}{|l|l|l|l|l|l|l|l|l|}
\hline & 1 & 2 & 3 & 4 & 5 & 6 & 7 & Total \\
\hline Capital & 970.265 & 819.152 & 5.345 .468 & 43.509 & 148.513 & 78.813 & 6.897 & 7.412 .617 \\
\hline Estado & 4.743 .150 & 2.603 .098 & 15.762 .638 & 147.724 & 800.519 & 444.550 & 122.014 & 24.623 .693 \\
\hline
\end{tabular}

Legenda:

Coluna 1: ciclomotor, motoneta, motocicleta, triciclo e quadriciclo

Coluna 2: micro-ônibus, camioneta, caminhonete e utilitário

Coluna 3: automóvel

Coluna 4: ônibus

Coluna 5: caminhão

Coluna 6: reboque e semirreboque

Coluna 7: outros (caminhão-trator, trator de rodas, trator de esteiras, trator misto, chassi/plataforma, sidecar, motor-casa).

Disponível na Internet: < https://www.detran.sp.gov.br/wps/portal/detran/odetran/estatisticasdotransito/sa-frota/>. Acesso em: 02 de maio de 2013.

${ }^{42}$ DERZI, Misabel de Abreu Machado. Direito tributário, direito penal e tipo, 2. ed. São Paulo: Revista dos Tribunais, 2008, p. 334.

${ }^{43}$ FERRAGUT, Maria Rita. Presunções no direito tributário. São Paulo: Dialética, 2001, p. 135. 
Como consideramos que uma das razões de existência das presunções é a praticabilidade, a utilização das pautas fiscais no IPVA é constitucional, por suprir deficiências probatórias, uma vez que a determinação do valor de cada veículo é praticamente impossível de ser feita, inviabilizando, ainda que de forma indireta, a tributação.

Na jurisprudência também não há vozes dissonantes quanto à possibilidade de utilização da tabela de veículos que, como forma de padronização da base de cálculo, não ofende a capacidade contributiva. Senão vejamos a seguinte ementa ${ }^{44}$ :

TRIBUTÁRIO. IPVA. TABELA DE VALORES. CORREÇÃO EFETUADA POR RESOLUÇÃOADMINISTRATIVA. INALTERADA A BASE DE CÁLCULO E O FATO GERADOR PREVISTOS NA LEI ESTADUAL DO RIO DE JANEIRO. CAPACIDADE CONTRIBUTIVA DO CONTRIBUINTE DEVIDAMENTE OBSERVADA (ART. $145, \S 1^{\circ}$, DA CF). LEGALIDADE. QUESTÕES NÃO VENTILADAS NA ORIGEM NÃO PODEM SER APRECIADAS, SOB PENA DE SUPRESSÃO DE INSTÂNCIA. PRECEDENTES DO STF E DO STJ.

1. A correção da tabela de valores no ano da cobrança do tributo não implica violência aos princípios insculpidos na Constituição Federal, uma vez que prevalecem o fato gerador, a base de cálculo e as alíquotas previstas na legislação estadual que instituiu o IPVA. A simples correção da tabela não tem o condão de modificar o fato gerador e a base de cálculo.

2. Capacidade contributiva no regime do IPVA, tal como disciplinado na Lei n. ${ }^{\circ} 948$, de 1985, do Estado do Rio de Janeiro. A base de cálculo do imposto é o valor venal do veículo, onerando o contribuinte segundo a grandeza do seu patrimônio, observado, assim, o princípio da capacidade contributiva.

3. Questões não suscitadas e debatidas em primeiro grau não podem ser apreciadas por esta Corte na esfera de seu conhecimento recursal, sob pena de ofensa ao princípio do duplo grau de jurisdição.

4. Precedentes do STF e do STJ.

5. Recurso conhecido, porém, improvido.

Na mesma linha o entendimento do STF, no seguinte acórdão ${ }^{45}$ :

IPVA - TABELA DE VALORES - CORREÇÃO.

A correção da tabela de valores no ano da cobrança do tributo não implica violência aos princípios insculpidos na Constituição Federal. Prevalecem o fato gerador, a base de cálculo e as alíquotas previstas na legislação estadual editada com observância aqueles princípios. A simples correção da tabela não modifica quer o fato gerador, quer a base de cálculo, no que se revelam como sendo a propriedade do veículo e o valor deste.

${ }^{44}$ STJ, RMS 8309 / RJ, Relatora Ministra LAURITA VAZ, 2a . Turma, Data do Julgamento: 28.08.2001.

DJ 08/10/2001

${ }^{45}$ STF, AI 169370 AgR / SP, Relator Min. MARCO AURÉLIO, 2ª Turma, Julgamento: 27.10.95. 
Com efeito, padronizar a base de cálculo com a média dos valores de mercado dos veículos de mesmo modelo e ano, desprezando-se estado de conservação e outros itens menores de diferenciação, torna possível a exequibilidade da norma, garantindo à receita indispensável ao Estado para consecução de suas finalidades, sem ofensa maior à capacidade contributiva individual.

O contribuinte poderá elidir o lançamento, demonstrando que não houve o fato gerador, ou seja, que não era proprietário do veículo no $1^{\circ}$. dia do ano; ou ainda que houve erro de fato no lançamento, demonstrando que o modelo de que é proprietário não corresponde àquele utilizado para a instituição do tributo.

Não cabe, no nosso entender, tentar impugnar o lançamento, demonstrando que o valor real do veículo é inferior ao utilizado como padrão na tabela ${ }^{46}$. Caso o contribuinte não concorde com o valor, deverá impugnar o lançamento, demonstrando que o valor padrão utilizado na tabela não corresponde à verdadeira média dos valores de mercado.

\footnotetext{
${ }^{46}$ De opinião contrária: "Se a indicação de tais valores configurar presunção relativa - portanto, elidível pelo contribuinte mediante documentação hábil a comprovar o valor real do bem -, não há objeção à adoção de pautas fiscais pela lei tributária". COSTA, Regina Helena. Praticabilidade e justiça tributária - Exequibilidade de Lei Tributária e Direitos do Contribuinte, São Paulo: Malheiros, 2007, p. 262.
} 


\subsection{Lucro Presumido}

É competência da União instituir imposto sobre a renda e proventos de qualquer natureza, nos termos do art. 153, III, da Constituição Federal. ${ }^{47}$

A base de cálculo deste imposto, consoante disposição do art. 44 do CTN, é: “o montante, real, arbitrado ou presumido, da renda ou dos proventos tributáveis".

O lucro real é o próprio lucro tributável, a própria base de cálculo utilizada na apuração do imposto de renda das pessoas jurídicas. De acordo com o art. 247 do RIR/1999 e art. $9^{\circ}$. e seguintes da lei $\mathrm{n}^{\circ}$. 9.249/95, lucro real é o lucro líquido do período de apuração ajustado pelas adições, exclusões ou compensações prescritas ou autorizadas pela legislação fiscal.

O lucro arbitrado é uma forma de apuração da base de cálculo do imposto de renda aplicável pela autoridade tributária quando a pessoa jurídica deixar de cumprir as obrigações acessórias relativas à determinação do lucro real ou presumido, conforme o caso. ${ }^{48}$

O lucro presumido ${ }^{49}$, objeto deste estudo, é uma forma de tributação simplificada para determinação da base de cálculo do imposto de renda e da CSLL - Contribuição Social sobre o Lucro Líquido, das pessoas jurídicas que não estiverem obrigadas ${ }^{50}$, no ano-calendário,

\footnotetext{
${ }^{47} \mathrm{CF} / 88$ : Art. 153. Compete à União instituir impostos sobre: [...] III - renda e proventos de qualquer natureza; [...].

${ }^{48}$ Lei n. 9.249/95. Art. 16. O lucro arbitrado das pessoas jurídicas será determinado mediante a aplicação, sobre a receita bruta, quando conhecida, dos percentuais fixados no art. 15, acrescidos de vinte por cento. Parágrafo único. No caso das instituições a que se refere o inciso III do art. 36 da Lei n ${ }^{\circ}$ 8.981, de 20 de janeiro de 1995, o percentual para determinação do lucro arbitrado será de quarenta e cinco por cento.

${ }^{49}$ Lei n. 9.430/96. Art. $2^{\circ}$ A pessoa jurídica sujeita a tributação com base no lucro real poderá optar pelo pagamento do imposto, em cada mês, determinado sobre base de cálculo estimada, mediante a aplicação, sobre a receita bruta auferida mensalmente, dos percentuais de que trata o art. 15 da Lei ${ }^{\circ} 9.249$, de 26 de dezembro de 1995 , observado o disposto nos $\S \S 1^{\circ}$ e $2^{\circ}$ do art. 29 e nos arts. 30 a 32, 34 e 35 da Lei ${ }^{\circ} 8.981$, de 20 de janeiro de 1995, com as alterações da Lei $n^{\circ} 9.065$, de 20 de junho de 1995.

$\S 1^{\circ} \mathrm{O}$ imposto a ser pago mensalmente na forma deste artigo será determinado mediante a aplicação, sobre a base de cálculo, da alíquota de quinze por cento. [...].

${ }^{50}$ Estão obrigadas ao regime de tributação com base no lucro real, em cada ano-calendário, as pessoas jurídicas:

a) cuja receita total, ou seja, o somatório da receita bruta mensal, das demais receitas e ganhos de capital, dos ganhos líquidos obtidos em operações realizadas nos mercados de renda variável e dos rendimentos nominais produzidos por aplicações financeiras de renda fixa, da parcela das receitas auferidas nas exportações às pessoas vinculadas ou aos países com tributação favorecida que exceder ao valor já apropriado na escrituração da empresa, na forma da IN SRF $n^{\circ} 38$, de 1997, no ano-calendário anterior, seja superior ao limite de $\mathrm{R} \$ 24.000 .000,00$ (vinte e quatro milhões de reais), ou de $\mathrm{R} \$ 2.000 .000,00$ (dois milhões de reais) multiplicado pelo número de meses do período, quando inferior a doze meses;

b) cujas atividades sejam de bancos comerciais, bancos de investimentos, bancos de desenvolvimento, caixas econômicas, sociedades de crédito, financiamento e investimento, sociedades de crédito imobiliário, sociedades corretoras de títulos, valores mobiliários e câmbio, distribuidoras de títulos e valores mobiliários, empresas de arrendamento mercantil, cooperativas de crédito, empresas de seguros privados e de capitalização e entidades de previdência privada aberta;

c) que tiverem lucros, rendimentos ou ganhos de capital oriundos do exterior;

d) que, autorizadas pela legislação tributária, usufruam de benefícios fiscais relativos à isenção ou redução do imposto;
} 
à apuração do lucro real. A opção pela apuração do imposto de renda com base no lucro presumido é irretratável para o ano-calendário (Lei nº 9.718, de 1998, art. 13, § $1^{\circ}$ ).

O regime do lucro presumido introduzido a partir do art. 33 do Decreto-lei 5.844 de 1943 é uma medida simplificadora que padroniza o lucro líquido a ser tributado, a partir da aplicação de uma alíquota fixa sobre a receita bruta, desconsiderando-se qualquer tipo de receita.

Não se pode negar que o lucro presumido tenha um viés extrafiscal ${ }^{52}$ de estímulo às empresas de pequeno e médio porte, ao limitar o ingresso nesse regime somente aos contribuintes que atingiram até um valor máximo de receita bruta anual, ou a determinado grupo de atividades.

Entretanto, como a grande massa de contribuintes está na abrangência deste regime, a desconsideração das demonstrações das despesas na apuração do lucro tributado, simplificou e viabilizou muito a fiscalização e gestão do tributo, tornando-se um excelente instrumento a serviço da praticabilidade.

A facultatividade do regime permite que eventuais contribuintes que fossem ser prejudicados por sua imposição, mantenham-se no regime de lucro real, afastando-se desta maneira qualquer agressão à capacidade contributiva individual.

Na doutrina majoritária, não há óbices à esta medida. REGINA HelENA CoSTA, v.g., assevera que:

e) que, no decorrer do ano-calendário, tenham efetuado pagamento mensal do imposto de renda, determinado sobre a base de cálculo estimada, na forma do art. $2^{\circ}$ da Lei ${ }^{\circ}$ 9.430, de 1996;

f) que explorem as atividades de prestação cumulativa e contínua de serviços de assessoria creditícia, mercadológica, gestão de crédito, seleção e riscos, administração de contas a pagar e a receber, compras de direitos creditórios resultantes de vendas mercantis a prazo ou de prestação de serviços ( factoring ).

${ }^{51}$ Dl. 5844/43. Art. 33 É facultado às pessoas jurídicas, salvo às sociedades por ações e às por quotas de responsabilidade limitada, optar pela tributação baseada no lucro presumido, segundo a forma estabelecida no art. 40.

$\S 1^{\circ}$ disposto neste artigo não se aplica às pessoas jurídicas cujo capital exceder a $\operatorname{Cr} \$ 50.000,00$ ou cujo movimento bruto anual fôr superior a Cr\$200.000,00, nem às filiais, sucursais ou agências no país das firmas e sociedades com sede no estrangeiro, as quais serão sempre tributadas pelo lucro real.

$\S 2^{\circ}$ A opção é irrevogável e será feita, em cada exercício, na própria declaração de rendimentos, devidamente subscrita. Art. 40. O lucro presumido será determinado pela aplicação do coeficiente de $8 \%$ sôbre a receita bruta.

$\S 1^{\circ}$ Constitui receita bruta a soma das operações, realizadas por conta própria e das remunerações recebidas como preço de serviços prestados.

$\S 2^{\circ}$ Incluem-se na receita bruta as receitas totais de transações alheias ao objeto do negócio

Art. 41. A comprovação da receita bruta será feita com a relação das vendas de conta própria registadas nos livros fiscais, durante o ano civil imediatamente anterior ao exercício financeiro em que o imposto for devido, e com os lançamentos feitos durante o ano social a crédito da conta ou contas que registem a receita da firma ou sociedade.

Art. 42. Do lucro presumido não será permitida dedução de qualquer espécie.

${ }^{52}$ Sobre o assunto: "É um benefício para aquelas sociedades que têm poucas despesas e, por consequência, não têm deduções significativas na sistemática do lucro real. Está aí a razão extrafiscal desse regime, estimulando toda empresa de pequeno e médio porte no País que aderir ao programa. Feita a escolha, procede-se à espécie de renúncia à forma real de apuração, de maneira que, rigorosamente, não haja impedimento de prova em contrário, mas simples renúncia na adesão ao regime do próprio contribuinte. Trata-se, pois, do caso de presunção hipotética de segundo nível irrevogável ou instituidora de regime jurídico especial”. HARET, Florence. Teoria e Prática das Presunções no Direito Tributário. São Paulo: Noeses, 2011, p. 639. 


\begin{abstract}
Não vemos vício que macule a adoção dessa presunção relativa de lucro. Isso porque se trata de opção a ser efetuada pelo contribuinte, facilitadora da apuração do imposto, desde que considere esse regime favorável a si.

O regime de estimativa, assim, traduz, igualmente, o adequado convívio entre os princípios da legalidade e da capacidade contributiva, de um lado, e da praticidade fiscal, de outro ${ }^{53}$.
\end{abstract}

Cabe a ressalva de que o contribuinte ao fazer a opção pelo regime, renuncia de forma irretratável durante o ano calendário da opção de apuração do lucro real como base de cálculo, ainda que este venha a se mostrar mais benéfico do que o lucro presumido.

Se fosse permitido ao contribuinte, a cada período de apuração do lucro, ficar transitando entre um regime e outro frustraria o fundamento de simplificação e tornaria impraticável a fiscalização do imposto.

FLORENCE HARET chamou esta base presuntiva de tipo presuntivo irrevogável ou constitutivo de regime jurídico diferenciado. Vejamos suas palavras:

\begin{abstract}
Lembremos que não é possível contestar esse valor com a apresentação do lucro apurado pela escritura fiscal no final do ano. As presunções se mostram aqui na figura de percentuais fixos, que serão assumidos como forma (presumida) de quantificação da renda obtida no período, mesmo mediante prova em contrário. Isto é, ainda que leve à Receita Federal livros contábeis (balanço, livro caixa, etc.) demonstrando renda menor naquele período do que aquela prevista em lei, a base de cálculo do IR será aquela legalmente indicada. A opção pelo regime jurídico implica renúncia, ou melhor, impedimento de discussão do fato jurídico e das bases de cálculo previamente estabelecidas em lei. ${ }^{54}$
\end{abstract}

Esse também é o entendimento da melhor jurisprudência, como mostra este julgado

do STJ:

PROCESSUAL CIVIL. AGRAVO REGIMENTAL. AGRAVO DE INSTRUMENTO.TRIBUTÁRIO. EMPRESA PRESTADORA DE SERVIÇOS DE AGENCIAMENTO DE MÃO-DE-OBRA TEMPORÁRIA. VERIFICAÇÃO DA BASE DE CÁLCULO DO IRPJ, DA CSLL, DO PIS E DA COFINS. VA̧LORES DESTINADOS AO PAGAMENTO DE SALÁRIOS E DEMAIS ENCARGOS TRABALHISTAS DOS TRABALHADORES TEMPORÁRIOS.

1. Ausente o interesse de agir em relação ao pedido de exclusão das bases de cálculo do IRPJ e da CSLL, devidos pela empresa de trabalho temporário, dos valores atinentes a salários e encargos da mão-de-obra contratada por conta e ordem dos tomadores de serviços, por já haver a previsão legal para tal dedução no regime de apuração pelo lucro real.

2. Não é possível para a empresa alegar em juízo que é optante pelo lucro presumido para em seguida exigir as benesses a que teria direito no regime de lucro real, mesclando os regimes de apuração.

\footnotetext{
${ }^{53}$ COSTA, Regina Helena. Praticabilidade e justiça tributária - Exequibilidade de Lei Tributária e Direitos do Contribuinte, São Paulo: Malheiros, 2007, p. 258-259.

${ }^{54}$ HARET, Florence. Teoria e Prática das Presunções no Direito Tributário. São Paulo: Noeses, 2011, p. 638.
} 
3. A base de cálculo do PIS e da COFINS, independentemente do regime normativo aplicável (Leis Complementares 7/70 e 70/91 ou Leis ordinárias 10.637/2002 e $10.833 / 2003$ ), abrange os valores recebidos pelas empresas prestadoras de serviços de locação de mão-de-obra temporária (regidas pela Lei 6.019/74 e pelo Decreto 73.841/74), a título de pagamento de salários e encargos sociais dos trabalhadores temporários.

4. Tema já julgado sob o regime do art. 543-C, do CPC, e da Resolução STJ 08/08 no REsp. n. 1.141.065 - SC, Primeira Seção, Rel. Min. Luiz Fux, julgado em 9.12.2009.

5. Agravo regimental não provido 55 . (Grifo nosso)

O lucro presumido apresenta-se como um excelente instrumento de simplificação, atendendo ao mandamento da praticabilidade, sem deixar de manter uma relação de razoabilidade com a média efetiva dos lucros apurados na classe de contribuintes contemplados.

Sua opcionalidade facilita enormemente sua ajustabilidade às eventuais situações díspares e permite aos contribuintes, além de eventuais reduções, a certeza e previsibilidade da carga fiscal a ser-lhe imposta pelo tributo, cristalizando a tão almejada segurança jurídica na tributação.

${ }^{55}$ STJ, AgRg nos EDcl no AgRg no AG no 1.105.816 - PR, Segunda Turma, Rel. Min. Mauro Campbell Marques, julgado em 02.12.2010. 


\subsection{Substituição Tributária Progressiva ou "Para Frente"}

A Constituição Federal de 1988, nos termos do art. 155, II, atribui competência aos Estados e ao Distrito Federal para instituir o imposto sobre operação de circulação de mercadorias e prestação de serviços de transporte e de comunicação - ICMS. ${ }^{56}$

A hipótese de incidência - operação de circulação de mercadorias - prevista no arquétipo constitucional tem com base de cálculo o valor efetivo ou real das mercadorias transacionadas nas operações de compra e venda, nas quais ocorre a transferência da propriedade.

Entretanto, os Estados e o Distrito Federal alegam que apurar o efetivo valor das mercadorias transacionadas requer recursos humanos e financeiros de grande monta, o que em face das deficiências crônicas de suas administrações torna o imposto impraticável.

A solução encontrada, como medida simplificadora apta a tornar a aplicação do tributo praticável, foi cobrar o imposto não quando a venda ocorre, mas antecipadamente, com base no seu valor presumido. Surgiu, assim, a substituição tributária.

Antes de analisarmos o instituto propriamente dito, vamos traçar um breve histórico de sua evolução desde sua criação até a sua positivação no texto constitucional. Assim como vários institutos jurídicos do direito tributário, a substituição foi evoluindo com a criação de vários diplomas legais ${ }^{57}$, muitas vezes desrespeitando direitos e garantias dos contribuintes em prol da comodidade da arrecadação.

Não obstante as recentes e relevantes discussões doutrinárias acerca da Substituição Tributária, seu surgimento remonta ao ano de 1966, quando o Código Tributário Nacional trouxe no art. 58, $\S 2^{\circ}$ a possibilidade de atribuir a condição de responsável ao comerciante ou ao industrial, quando adquirissem de produtor, pelo imposto devido na saída das mercadorias, portanto, responsabilidade pela etapa anterior, e ao industrial ou comerciante atacadista, pelo imposto da etapa posterior, isto é, do imposto devido por comerciante varejista. ${ }^{58}$

\footnotetext{
${ }^{56} \mathrm{CF} / 88$. Art. 155. Compete aos Estados e ao Distrito Federal instituir impostos sobre: [...] II - operações relativas à circulação de mercadorias e sobre prestações de serviços de transporte interestadual e intermunicipal e de comunicação, ainda que as operações e as prestações se iniciem no exterior; [...]

${ }^{57}$ Clélio Chieza aponta que: "A nosso ver, boa parte dos problemas que eclodiram até hoje em torno da criação e aplicação do instituto da substituição tributária enfrenta um obstáculo quase instransponível: a precariedade da normatização. Vale dizer, o caos instaurado decorre principalmente da maneira como a matéria foi disciplinada no ordenamento jurídico positivo". CHIEZA, Clélio. ICMS. A Denominada Substituição Tributária "Para Frente". Revista dos Tribunais, São Paulo, OutubroDezembro de 1999, Ano 7, n. 29, p. 50.

${ }^{58} \mathrm{CTN}$. Art. 58. Contribuinte do imposto é o comerciante, industrial ou produtor que promova a saída da mercadoria. $[\ldots]$

$\S 2^{\circ}$ A lei pode atribuir a condição de responsável:

I - ao comerciante ou industrial, quanto ao imposto devido por produtor pela saída de mercadoria a eles destinada;
} 
Apenas um ano após a promulgação do Código Tributário Nacional, o Ato Complementar $\mathrm{n}^{\circ}$ 34, de 30.1.1967 alterou o inciso II, trazendo nova forma de apuração da base de cálculo ${ }^{59}$ sobre a venda na etapa seguinte, ou seja, aquela venda futura que ainda não ocorreu.

A base de cálculo para a transação futura e incerta passou a ser o preço máximo de venda determinado pelo fabricante, ou na falta deste, o valor determinado pela autoridade competente, ou ainda, de $30 \%$ sobre o preço cobrado pelo substituto.

Esse dispositivo foi expressamente revogado pelo art. 13 do Decreto-lei n. 406/68, que entrou em vigor em 01/01/1969, pois à época o STF entendeu (RE 77.462, 77.885 e 108.407) que era incabível atribuir a qualidade de substituto ao industrial ou atacadista pelas vendas efetuadas pelos comerciantes varejistas, com base somente no art. 128 do Código Tributário Nacional, em razão da necessidade de vinculação do substituto ao fato gerador. ${ }^{60}$

Com a revogação deste artigo, exclui-se, em tese, do ordenamento brasileiro a possibilidade de tributação por intermédio da substituição tributária. Em tese, pois na prática, os Estados continuaram, como arrimo em normas e convênios estaduais, utilizando-se de forma inconstitucional deste instituto.

Com a edição da lei complementar n. 44, publicada em 07 de dezembro de 1983, que acrescentou o $\S 9^{\circ}$. ao art. $2^{\circ}$. e trouxe alterações ao artigo e $6^{\circ}$. do Decreto-Lei n. 406/68, novamente ficou positivada a possibilidade da instituição de tributos mediante o mecanismo da substituição tributária. ${ }^{61}$

II - ao industrial ou comerciante atacadista, quanto ao imposto devido por comerciante varejista, mediante acréscimo, ao preço da mercadoria a ele remetida, de percentagem não excedente de $30 \%$ (trinta por cento) que a lei fixar;

a) da margem de lucro atribuída ao revendedor, no caso de mercadoria com preço máximo de venda no varejo marcado pelo fabricante ou fixado pela autoridade competente;

b) de percentagem de $30 \%$ (trinta por cento) calculada sobre o preço total cobrado pelo vendedor, neste incluído, se incidente na operação, o imposto a que se refere o art. 46, nos demais casos.

III - à cooperativa de produtores, quanto ao imposto relativo às mercadorias a ela entregues por seus associados. $[\ldots]$

${ }^{59} \mathrm{II}$ - ao industrial ou comerciante atacadista, quanto ao imposto devido por comerciante varejista, mediante acréscimo:

a) da margem de lucro atribuída ao revendedor, no caso de mercadoria com preço máximo de venda no varejo marcado pelo fabricante ou fixado pela autoridade competente;

b) de percentagem de $30 \%$ (trinta por cento) calculada sobre o preço total cobrado pelo vendedor, neste incluído, se incidente na operação, o imposto a que se refere o art. 46, nos demais casos.

${ }^{60} \mathrm{CTN}$. Art. 128. Sem prejuízo do disposto neste capítulo, a lei pode atribuir de modo expresso a responsabilidade pelo crédito tributário a terceira pessoa, vinculada ao fato gerador da respectiva obrigação, excluindo a responsabilidade do contribuinte ou atribuindo-a a este em caráter supletivo do§ cumprimento total ou parcial da referida obrigação.

${ }^{61}$ Dl. n. 406/68. Art. $2^{\circ}$. - A base de cálculo do imposto é: [...] § $9^{\circ}$. Quando for atribuída a condição de responsável, ao industrial, ao comerciante atacadista ou ao produtor, relativamente ao imposto devido pelo comerciante varejista, a base de cálculo do imposto será: [...] b) o valor da operação promovida pelo responsável, acrescido da margem de lucro atribuída ao revendedor, no caso de mercadorias com preço de venda, máximo ou único, marcado pelo fabricante ou fixado pela autoridade competente.

Art. $6^{\circ}$. [...] $\S 3^{\circ} \mathrm{A}$ lei estadual poderá atribuir a condição de responsável:

a) ao industrial, comerciante ou outra categoria de contribuinte, quanto ao imposto devido na operação ou operações anteriores promovidas com a mercadoria ou seus insumos;

b) ao produtor industrial ou comerciante atacadista, quanto ao imposto devido pelo comerciante varejista;

c) ao produtor ou industrial, quanto ao imposto devido pelo comerciante atacadista e pelo comerciante varejista;

d) aos transportadores, depositários e demais encarregados da guarda ou comercialização de mercadorias. 
Com a competência reservada pelo $\S 1^{\circ}$. do art. 19 da Constituição de 1967 em relação ao ICM da época, o legislador complementar contemplou a substituição tributária tanto para as operações anteriores, como em relação às subsequentes, sem disciplinar que houvesse qualquer tipo de restituição de imposto no caso da não realização do fato gerador.

Embora fortemente criticada pela doutrina à época, pela falta de respaldo constitucional, a substituição tributária, em razão da racionalidade que trazia ao Fisco no combate à sonegação e a praticabilidade na arrecadação, passou a ser vista como algo que "veio para ficar" e que dificilmente seria eliminada como técnica arrecadatória.

A Constituição Federal de 1988 determinou que a instituição do ICMS deveria ser por intermédio de lei complementar, mas para que não inviabilizasse a cobrança do tributo na falta desta lei, foi acrescentado o artigo $34, \S 8^{\circ}$., do Ato das Disposições Constitucionais Transitórias, que trouxe a possibilidade de, na falta da edição da Lei complementar necessária à instituição do ICMS, os Estados e Distrito Federal poderiam, mediante convênios, fixar normas para regular provisoriamente a matéria.

Os Estados, para não ficarem sem a arrecadação de sua principal fonte de receita, rapidamente reuniram-se e celebraram o Convênio ICM n. 66/88. Conforme disposição constitucional, este Convênio deveria ater-se a regular provisoriamente a matéria, suprindo no que fosse necessário para a instituição e regulamentação do tributo, mas isso, de fato, não ocorreu, "ele foi muito além, pretendeu até dispor sobre matéria que já estava regulada por lei complementar, vindo a dispor de modo diferente". ${ }^{62}$

É que a Constituição Federal, em seu texto original ${ }^{63}$, reservava à lei complementar regular sobre substituição tributária do ICMS, sem disciplinar suas modalidades (regressiva e progressiva) e, na ausência desta lei, todas as disposições da lei complementar n. 44/83, não recepcionadas pela nova Carta, foram inseridas no referido Convênio, em seus artigos 23 a 26.

Obviamente que essa usurpação por via transversa de competência não passou incólume pela doutrina ${ }^{64}$ e, tamanha foi a repercussão que em 1993, sob forte pressão dos

\footnotetext{
$\S 4^{\circ}$ Caso o responsável e o contribuinte substituído estejam estabelecidos em Estados diversos, a substituição dependerá de convênio entre os Estados interessados.

${ }^{62}$ CHIEZA, Clélio. ICMS. A Denominada Substituição Tributária "Para Frente". Revista dos Tribunais, São Paulo: Revista dos Tribunais, Ano 7, n. 29, p. 61, out.-dez. 1999.

${ }^{63} \mathrm{CF} / 88$. Art. 155. Compete aos Estados e ao Distrito Federal instituir impostos sobre: [...]II - operações relativas à circulação de mercadorias e sobre prestações de serviços de transporte interestadual e intermunicipal e de comunicação, ainda que as operações e as prestações se iniciem no exterior; [...]

$\S 2^{\circ} \mathrm{O}$ imposto previsto no inciso II atenderá ao seguinte:[...]

XII - cabe à lei complementar: [...]

b) dispor sobre substituição tributária;

${ }^{64}$ Assim a doutrina: "Os contornos das regras matrizes dos tributos foram cuidadosamente traçados na Constituição Federal. Vale dizer que os fatos que podem dar ensejo à criação de tributos foram rigorosamente delimitados no texto constitucional. $\mathrm{O}$ legislador ordinário somente poderá instituir tributo sobre esses fatos exaustivamente indicados, sob pena de incorrer em vitanda inconstitucionalidade.
} 
Estados, foi editada a Emenda Constitucional n. 3/93, que com o $§ 7^{\circ}$. do art. 150 , sedimentou em sede constitucional a substituição tributária sobre fato gerador presumido:

Art. 150. Sem prejuízo de outras garantias asseguradas ao contribuinte, é vedado à União, aos Estados, ao Distrito Federal e aos Municípios:

$[\ldots]$

§ 7..$^{\circ}$ A lei poderá atribuir a sujeito passivo de obrigação tributária a condição de responsável pelo pagamento de imposto ou contribuição, cujo fato gerador deva ocorrer posteriormente, assegurada a imediata e preferencial restituição da quantia paga, caso não se realize o fato gerador presumido.

Ainda que a criação da substituição tributária progressiva tenha ocorrido em leis e decretos anteriores, esse dispositivo constitucional inovou seja na instituição do fato gerador presumido, antecipando o momento do surgimento da obrigação, seja no estabelecimento da garantia de reembolso preferencial e imediato da quantia paga a título de tributo, caso não realizado o fato gerador presumido.

Essa cláusula de restituição imediata e preferencial, a ser regulamentada por lei, inviabilizou o instituto da substituição tributária até a promulgação da lei complementar n. 87/96, conhecida por Lei Kandir, que tratou do tema da substituição tributária nos arts. $6^{\circ}$. a 10, regulamentando de forma bem mais detalhada o instituto, com a previsão das modalidades regressivas, concomitantes e progressivas, bem como o direito à restituição do imposto pago correspondente ao fato gerador presumido que não se realizar.

Mas o que é essa norma, com fundamento de validade na Constituição, que institui a substituição tributária?

Após a ocorrência do fato gerador surge a obrigação tributária, composta pelo sujeito ativo "titular do direito subjetivo público de exigir o cumprimento da prestação pecuniária ao tributo e outro - o sujeito passivo, portador do dever jurídico de adimplir referida prestação". ${ }^{65}$

$[\ldots]$

Portanto, a nosso ver, os representantes dos Estados e do Distrito Federal, ao estabelecerem no Convênio 66/88 a faculdade para tributar "fatos geradores presumidos", extrapassaram a competência que lhe foi outorgada pelo art. 34 do ADCT, sob o pretexto de editar normas necessárias à instituição do ICMS”. CHIEZA, Clélio. ICMS. A Denominada Substituição Tributária "Para Frente". Revista dos Tribunais, São Paulo: Revista dos Tribunais, Ano 7, n. 29, p. 58, out.-dez. 1999. Para Roque Antonio Carrazza "só a lei complementar pode disciplinar o instituto da substituição tributária (ex vi do art. 155, § $2^{\circ}$., XII, b, da Constituição Federal)" "64. E como a lei complementar só foi editada em 1996, ele arremata: "Portanto, os Convênios 66/88, 105/89, 107/89 e 111 a 113/93, nas partes em que cuidaram de substituição tributária para frente, "possibilitando" a antecipação do recolhimento do ICMS (sobre fatos futuros, isto é, não ocorridos) e 'estabelecendo' que a base de cálculo deste tributo seria fundada em fictício e estimado valor de tabela, sempre foram manifestadamente inconstitucionais”. CARAZZA, Roque Antonio. ICMS. 10 ed. São Paulo: Malheiros, 2005, p. 226.

${ }^{65}$ CARVALHO, Paulo de Barros. Direito Tributário Linguagem e Método. 3. ed. São Paulo: Noeses, 2009, p. 623-624. Define: "Sujeito passivo da obrigação tributária é, por sua vez, a pessoa física ou jurídica, privada ou pública, de quem se exige o 
Segundo o art. 121 do $\mathrm{CTN}^{66}$ o sujeito passivo pode ser: contribuinte, quando efetivamente realizou o fato gerador; ou responsável, como aquele que não praticou o fato, mas eleito pela lei como responsável pelo crédito tributário. Como bem diferenciou MARIA RITA FERRAGUT:

Contribuinte é a pessoa que realizou o fato jurídico tributário, e que cumulativamente encontra-se no pólo passivo da relação obrigacional. Se uma das duas condições estiver ausente, ou o sujeito será o responsável, ou será o realizador do fato jurídico, mas não o contribuinte. Praticar o evento, portanto, é condição necessária para essa qualificação, mas insuficiente ${ }^{67}$.

Em razão do Código Tributário Nacional tratar sob a rubrica de responsável ${ }^{68}$ as várias modalidades diversificadas possíveis de sujeição passiva: substituição e a responsabilidade por transferência (decorrente de solidariedade, sucessão ou responsabilidade stricto sensu), acatamos a sugestão proposta por Luís EDUARDO SCHOUERI ${ }^{69}$ de se desdobrar a categoria do responsável lato sensu em substituto e responsável stricto sensu, da seguinte forma:

Fala-se em substituição quando o legislador, conquanto descrevendo uma conduta praticada por uma pessoa (contribuinte) como hipótese tributária, determina que, verificada aquela conduta, outra pessoa (substituto) terá a obrigação de recolher o tributo.

Já a responsabilidade stricto sensu (por transferência) surgirá quando o legislador, embora definindo um sujeito passivo pela verificação do fato jurídico tributário, determina, em virtude de outro fato (diverso do fato jurídico tributário) que outra pessoa passará a ser responsável (solidariamente ou não) pelo recolhimento do tributo devido pelo primeiro. (Grifo nosso)

\section{Como ensinam Sacha Calmon Navarro Coelho ${ }^{70}$ e Paulo de Barros}

CARVALHO $^{71}$, a substituição ocorre em momento pré-jurídico, quando o legislador, por razões

cumprimento da prestação pecuniária. Esse é, em termos jurídicos, o contribuinte, ou seja, aquele que deve realizar o pagamento dos tributos eventualmente devidos".

${ }^{66} \mathrm{CTN}$. Art. 121. Sujeito passivo da obrigação principal é a pessoa obrigada ao pagamento de tributo ou penalidade pecuniária. Parágrafo único. O sujeito passivo da obrigação principal diz-se:

I - contribuinte, quando tenha relação pessoal e direta com a situação que constitua o respectivo fato gerador;

II - responsável, quando, sem revestir a condição de contribuinte, sua obrigação decorra de disposição expressa de lei.

${ }^{67}$ FERRAGUT, Maria Rita. Responsabilidade tributária e o Código Civil de 2002. São Paulo: Noeses, 2005, pp. 29-30.

${ }^{68} \mathrm{CTN}$. Art. 128. Sem prejuízo do disposto neste capítulo, a lei pode atribuir de modo expresso a responsabilidade pelo crédito tributário a terceira pessoa, vinculada ao fato gerador da respectiva obrigação, excluindo a responsabilidade do contribuinte ou atribuindo-a a este em caráter supletivo do cumprimento total ou parcial da referida obrigação.

${ }^{69}$ SCHOUERI, Luís Eduardo. Direito Tributário. São Paulo: Saraiva, 2011, p. 478.

${ }^{70}$ COÊLHO, Sacha Calmon Navarro. Curso de Direito Tributário brasileiro. Rio de Janeiro: Forense, 1999, p. 604.

${ }^{71}$ Paulo de Barros Carvalho aduz que a opção do legislador ocorre em um intervalo meramente político: "Não sobeja repisar que a substituição de que falam os mestres, ou que registram os textos prescritivos, dista de ser fenômeno jurídico em que um sujeito de direitos cede lugar a outro sujeito de direitos, sob o pálio de determinado regime, como sugere o termo. A modificação se produz antes que o texto seja editado, em tempo que antecede o aparecimento da disciplina jurídica sobre a matéria. Estamos diante de algo que se opera em intervalo meramente político, quando o legislador prepara sua decisão e a norma ainda não logrou entrar no sistema”. CARVALHO, Paulo de Barros. Direito Tributário Linguagem e Método. 3. ed. São Paulo: Noeses, 2009 , p. 648. 
extrajurídicas, opta por colocar como sujeito passivo da obrigação tributária outra pessoa (substituto), que não aquela que realizou o fato jurídico tributário (substituído).

Várias são as razões que levam o legislador a optar pela substituição, tais como: comodidade na arrecadação, garantia do crédito, proteção contra a evasão, mas o que mais nos interessa neste trabalho - a praticabilidade. ${ }^{72}$

A substituição tributária é um exemplo cabal de criação de mecanismos a serviço da praticabilidade, que se justifica, segundo LUís QUEIROZ, por três razões ${ }^{73}$ :

- Pela dificuldade em fiscalizar contribuintes extremamente pulverizados;

- Pela necessidade de evitar, mediante a concentração da fiscalização, a evasão fiscal ilícita;

- Como medida indicada para agilizar a arrecadação e, consequentemente, acelerar a disponibilidade de recursos.

A locução substituição tributária apresenta conteúdo semântico impreciso, que causa confusão ao intérprete do direito, ao servir para designar três modalidades distintas: (i) regressiva; (ii) concomitante; e, (iii) progressiva. Em homenagem ao rigor científico, faz-se necessário discernir esses institutos.

A lei complementar n. 87/96 prescreve no art. $6^{\circ} ., \S 1^{\circ}$. as modalidades de substituição tributária; vejamos:

\begin{abstract}
Art. 6o ${ }^{-}$Lei estadual poderá atribuir a contribuinte do imposto ou a depositário a qualquer título a responsabilidade pelo seu pagamento, hipótese em que assumirá a condição de substituto tributário.

$\S 1^{\circ}$ A responsabilidade poderá ser atribuída em relação ao imposto incidente sobre uma ou mais operações ou prestações, sejam antecedentes, concomitantes ou subseqüientes, inclusive ao valor decorrente da diferença entre alíquotas interna e interestadual nas operações e prestações que destinem bens e serviços a consumidor final localizado em outro Estado, que seja contribuinte do imposto. (Grifamos)
\end{abstract}

Na substituição regressiva ou para trás, a opção do legislador é escolher como o responsável pelo pagamento do tributo, "pessoa que participa da cadeia circulatória em momento posterior ao da ocorrência do fato gerador, em substituição ao sujeito passivo direto anterior". ${ }^{74}$

Tal escolha se dá por comodidade do físco como, por exemplo, quando vários produtores rurais de pequeno porte ou pequenos comerciantes vendem para o industrial ou para

\footnotetext{
72 Derzi. Praticidade. ICMS. Substituição tributária progressiva, "para frente". In: Construindo o Direito Tributário na Constituição: uma análise da obra do Ministro Carlos Mário Velloso. Belo Horizonte: Del Rey, 2004, p. 171.

${ }^{73}$ QUEIROZ, Luís Cesar Souza de. Sujeição Passiva Tributária.2.ed. Rio de Janeiro: Forense, 2002, p. 199.

${ }^{74}$ BENÍCIO, Sérgio Gonini. ICMS Apontamentos Teóricos e Práticos sobre a Substituição Tributária. São Paulo: Saraiva, 2010, p. 134
} 
um grande distribuidor. O tributo, ao invés de ser recolhido por milhares de produtores, exigese seu recolhimento de um só contribuinte, possibilitando uma fiscalização bem mais simples e menos onerosa, hábil a evitar comportamentos evasivos.

Em vários exemplos como: "produtor rural que vende frutas para indústria de sucos, batatas para indústria de salgadinhos, café para indústria torrefadora etc." ${ }^{75}$, ocorre o diferimento do tributo, com a postergação de seu recolhimento e transferência da responsabilidade para o substituto:

No diferimento, o fato gerador acontece, a operação é tributada, porém o momento do pagamento é postergado e a responsabilidade é transferida para outra pessoa. $\mathrm{O}$ responsável (substituto) que adquire a mercadoria livre do imposto, ficará, entretanto, com a obrigação em relação ao fato gerador já ocorrido ${ }^{76}$.

Na substituição tributária concomitante, como o próprio nome diz, o pagamento do tributo será realizado pelo substituto, concomitantemente com o nascimento da obrigação, por fato jurídico tributário praticado pelo substituído.

Vários Estados preferem cobrar o ICMS incidente sobre o serviço de transporte prestado por autônomos e por transportadoras de outro Estado de um substituto, no caso, um contribuinte do Estado que contratou o transportador. Assim, por exemplo, uma empresa que contrata um transportador para levar uma mercadoria, pode ser colocada com substituta do ICMS sobre a prestação de serviço de transporte, descontando o valor do transportador e recolhendo ao Estado como sujeito passivo por substituição tributária, em relação ao ICMS sobre o serviço de transporte. ${ }^{77}$

Na substituição tributária progressiva ou para frente, diferentemente das anteriores, o constituinte (art. $150, \S 7^{\circ}$. da $\mathrm{CF} / 88$ ) elegeu um substituto sobre fatos jurídicos de provável ocorrência no futuro, i.e., fatos presumidos.

Esta técnica, com esteio na praticabilidade, é a mais utilizada, primeiro em razão da antecipação do valor do tributo e, também, pela facilidade de fiscalização. Conforme lembra JOSÉ ROBERTO ROSA ${ }^{78}$ :

Quando determinado produto tem poucos fabricantes ou importadores e um sem número de comerciantes que o revendem, pode ser interessante para o Estado exigir do fabricante ou do importador que, ao vender para o comerciante, calcule, à parte, o valor presumido da venda futura do comerciante e já cobre na nota fiscal, em separado, o valor do ICMS retido por substituição tributária, em relação às operações

\footnotetext{
${ }^{75}$ ROSA, José Roberto. Substituição Tributária no ICMS. 2.ed. São Paulo: OTTONI, 2009. p. 09.

${ }^{76}$ Ibidem, p. 09. No mesmo sentido: TORRES, Ricardo Lobo. Curso de Direito Financeiro e Tributário. 14. ed. Rio de Janeiro: Renovar, 2007, p. 264; CARVALHO, Paulo de Barros. Direito Tributário Linguagem e Método. 3. ed. São Paulo: Noeses, 2009, p. 650-651. Com opinião contrária, José Eduardo Soares de Melo e Luiz Francisco Lippo ${ }^{76}$, entendem que a substituição tributária, como transferência de responsabilidade do sujeito passivo, não se confunde com o diferimento, que é mera postergação do pagamento do tributo, em momento posterior, pelo próprio contribuinte. LIPPO, Luiz Francisco; MELO, José Eduardo Soares de. A não cumulatividade tributária. São Paulo: Dialética, 1998, p. 153.

${ }^{77}$ ROSA, José Roberto. Substituição Tributária no ICMS. 2.ed. São Paulo: OTTONI, 2009, p. 09.

${ }^{78}$ ROSA, José Roberto. Substituição Tributária no ICMS. 2. ed. São Paulo: OTTONI, 2009, p. 10.
} 
subseqüentes. O fabricante ou importador será o substituto e repassará ao Estado, separadamente do valor do seu imposto próprio, o valor do ICMS retido por substituição tributária de seus clientes revendedores.

Em vez do diferimento, o fenômeno agora é antecipação do pressuposto material que ainda não ocorreu, mas presume-se com grande probabilidade que ocorrerá, e a modificação do montante da operação (repita-se que ainda não ocorreu), substituindo-se o valor real da venda, por um valor padronizado representativo das médias dos valores. Este valor padronizado “como unidade na diversidade real de valores, necessariamente abrangerá casos em que o valor real é menor que o da unidade, quando casos em que o valor real é maior que o da média".79

As modalidades regressivas e concomitantes de substituição tributária decorrem com o próprio fato jurídico concretizado e têm como fundamento o art. 128 do CTN, enquanto na substituição "para frente", o substituto deverá recolher o tributo devido pelo substituído (contribuinte) sobre fato jurídico presumido, que terá grande probabilidade de vir a ocorrer no futuro, tendo como fundamento legal o art. $150, \S 7^{\circ}$. da CF/88 e na lei complementar n. 87/96.

Não resta dúvida de que tratamos de institutos distintos e "que não podem ser confundidos, eis que desfrutam de regulamentação própria, não se podendo aplicar as normas pertinentes a um instituto ao outro, salvo em caráter subsidiário, naquilo que não forem incompatíveis". ${ }^{80}$

Ainda no campo da delimitação do objeto, importante destacar que a substituição tributária não se confunde com a obrigatoriedade de recolhimento na fonte pela fonte pagadora $^{81}$, como, v.g., no caso do imposto de renda das pessoas físicas.

\footnotetext{
79 ÁVILA, Humberto. Substituição tributária e base de cálculo: os limites da padronização fiscal. Revista da Ajuris, v.32, n.100. Porto Alegre: Livraria do Advogado, 2005, p. 171.

${ }^{80}$ CHIEZA, Clélio. ICMS. A Denominada Substituição Tributária "Para Frente". Revista dos Tribunais, São Paulo: Revista dos Tribunais, ano 7, n. 29, p. 57, out.-dez. 1999. O autor chega a afirmar que "a denominada substituição para frente é um falso problema de substituição". Ibidem, p. 56. É o que também concluiu Luís Eduardo Schoueri: "Decorre de imediato do dispositivo acima transcrito que já não se está diante de uma substituição, nos moldes explicados acima. Na chamada "substituição para frente", espera-se que o "substituto" recolha o tributo antes mesmo de se ter imputado ao contribuinte um fato jurídico tributário. Se na substituição "para trás", a sujeição passiva surgia com o próprio fato jurídico tributário, agora se tem algo diverso: a situação que dará azo à sujeição passiva é diversa (e até mesmo anterior) ao fato jurídico tributário”. SCHOUERI, Luís Eduardo. Direito Tributário. São Paulo: Saraiva, 2011, p. 484.

${ }^{81}$ Assim a doutrina: "[...] um dos maiores erros doutrinários da nossa história foi o de tentar oferecer uma explicação da substituição tributária como se fosse, o substituto, um 'agente de retenção', estipulando a substituição como um gênero, em face de duas espécies distintas. Substituição tributária é o mecanismo de arrecadação que, inserindo um terceiro sujeito na relação jurídica entre o Fisco e contribuinte, atribui àquele obrigação própria para antecipar o pagamento dos valores devidos por este, com ulterior ressarcimento decorrente do regime plurifásico, extinguindo-se a obrigação tributária apenas com a ocorrência do fato gerador previsto para o contribuinte. Assim, 'substituto tributário' é aquele sujeito que, submetido a uma obrigação típica, antecipa o dever atribuído ao contribuinte, pagando o tributo que virá a ser devido por este, em seu nome (do substituto), porque assim dispôs a lei. Trata-se de um 'intermediário' legalmente interposto, para os fins da arrecadação tributária, mas com obrigação patrimonial própria. E aqui, diversamente do que acontece com os agentes de retenção, o substituído não fica como se fosse um estranho à sistemática de arrecadação, porquanto esta não se opera exclusivamente em face do substituto, na medida em que será a situação jurídica do substituído a que servirá como base para incidência da norma tributária impositiva (no substituto), pela respectiva demonstração de capacidade contributiva, além de se operar necessariamente o regime de compensação entre o substituto e o substituído, de modo a retirar deste o impacto da incidência tributária. Neste caso, o regime jurídico aplicável será sempre o do substituído, de tal sorte a termos, assim, pelo menos duas
} 
Não há similaridade entre a responsabilidade pelo recolhimento da fonte pagadora, que se torna sujeito passivo após o surgimento da obrigação tributária por ato praticado pelo real contribuinte, e a substituição, na qual a obrigação pelo recolhimento já surge antes mesmo dos fatos tributários terem sido praticados pelo contribuinte, no caso o substituído. É o que já decidiu o Conselho de Contribuintes do Ministério da Fazenda:

\begin{abstract}
Imposto de renda na fonte a título de antecipação do imposto devido na declaração de ajuste anual - Ação fiscal iniciada após a ocorrência do fato gerador e data da entrega da declaração de ajuste anual - Beneficiários identificados - Exclusão da responsabilidade da fonte pagadora pelo recolhimento do imposto devido - Sendo o imposto de renda na fonte tributo devido mensalmente pelo beneficiário do rendimento, cujo quantum deverá ser informado na Declaração de Ajuste Anual para a determinação de diferenças a serem pagas ou restituídas, e se a ação fiscal desenvolveu-se após a ocorrência do fato gerador e data da entrega da Declaração de Ajuste Anual, incabível a constituição de crédito tributário através do lançamento de imposto de renda na fonte na pessoa jurídica pagadora dos rendimentos. $\mathrm{O}$ lançamento, a título de imposto de renda - pessoa física -, ser for o caso, há que ser efetuado em nome do sujeito passivo direto da obrigação tributária, ou seja, o beneficiário e titular da disponibilidade jurídica e econômica do rendimento, exceto no regime de exclusividade do imposto na fonte. A falta de retenção do imposto de renda na fonte pela fonte pagadora não exonera o beneficiário dos rendimentos da obrigação de incluí-los, para fins de tributação, na Declaração de Ajuste Anual. Esta inclusão deverá ser efetuada pelo sujeito passivo direto da obrigação tributária ou, exofficio, pela Autoridade Fiscal. ${ }^{82}$
\end{abstract}

Acreditamos que agora, após essas considerações, podemos cingir nossa análise no instituto da substituição tributária para frente que como um mecanismo eficiente a serviço da praticabilidade, torna mais viável e menos onerosa a aplicação e fiscalização do ICMS à administração pública, sem deixar de atender à maior garantia do crédito e controle da sonegação, reduzindo a alguns poucos contribuintes substitutos a obrigação pelo recolhimento antecipado do tributo de fatos presumidos a serem praticados por milhares de outros contribuintes substituídos.

A doutrina majoritária rechaça o instituto da substituição tributária. São muitos os óbices apontados à sua instituição pelos mais renomados juristas, sendo que entre eles, os mais recorrentes são: a sua comparação a um confisco; ou a um empréstimo compulsório sem as devidas garantias constitucionais; ou ainda a vedação ao Estado de deixar de colher o verdadeiro

\footnotetext{
normas distintas incidindo: uma que define a obrigação patrimonial do substituto; e outra tomando o substituído como sendo sujeito passivo de obrigação própria, quando da ocorrência do respectivo fato gerador constitucionalmente pressuposto para confirmar os efeitos da definitividade da arrecadação". TÔRRES, Heleno Taveira.. Substituição Tributária - regime constitucional, classificação e relações jurídicas (materiais e processuais), Revista Dialética de Direito Tributário, n.70. São Paulo: Dialética, 2001, p. 87-88.

82 2a. Câmara do Primeiro Conselho, Proc. 10.820.001.386/99-90, ac 10.245.717, j. 19.09.02.
} 
contribuinte como sujeito passivo, para discricionária e arbitrariamente colher outra, por simples comodidade da arrecadação, como se observa neste trecho de GERALDO ATALIBA ${ }^{83}$ :

Será sujeito passivo, no sistema tributário brasileiro, a pessoa que provoca, desencadeia ou produz a materialidade da hipótese de incidência de um tributo (como inferida da Constituição) ou quem tenha relação pessoal e direta - como diz o art. 121, par. único, I, do CTN - com essa materialidade. Efetivamente, por simples comodidade ou por qualquer outra razão, não pode o Estado deixar de colher uma pessoa, como sujeito passivo para discricionária e arbitrariamente, colher outra.

Critica-se ainda a substituição tributária por ser ofensiva ao princípio da legalidade, ao descrever fato futuro por presunção, e aos princípios da não-cumulatividade e neutralidade, como procurou demonstrar MISABEL DERZI ${ }^{84}$ ao expor que:

Se recolhido o imposto antecipadamente sobre preços superiores àqueles realmente acontecidos, verifica-se que, além do aumento do tributo, o direito de repassar o custo do imposto ao adquirente-consumidor ficou atingido, prejudicado, passando o tributo a onerar o contribuinte comerciante, exatamente o que não quer a Constituição. Perde o ICMS a neutralidade com que foi dotado pela Constituição.

Aliás, a tributação sobre fatos futuros e presumidos é o argumento mais utilizado pelos contrários à sua instituição, uma vez que, com a substituição tributária, exige-se tributo antes da ocorrência do fato gerador e, ainda por cima, utilizando-se uma base de cálculo presumida. Vejamos alguns exemplos dessas críticas.

Para ROQUE CARRAZZA ${ }^{85}$, a emenda complementar 03/93 é inconstitucional ${ }^{86}$ ao criar a figura da responsabilidade tributária por fato futuro. Ele reconhece que o direito cria suas próprias realidades, mas a Constituição deve ser o limite para o emprego de ficções e presunções, de forma que sejam respeitados os direitos e garantias fundamentais. Como o dispositivo permite que a lei crie presunções de acontecimentos futuros, gerando assim obrigações tributárias, ele sustenta que:

\footnotetext{
${ }^{83}$ ATALIBA, Geraldo. Hipótese de incidência tributária. 6. ed. São Paulo: Malheiros, 2005, p. 78. Para o jurista a determinação do sujeito passivo depende da hipótese de incidência, que é prefixada pela Constituição. Em razão dessa premissa, juntamente com Cléber Giardino asseverou: "Seria supremo arbítrio exigir tributo de alguém, simplesmente pela circunstância de que é mais fácil colhê-lo do que ao destinatário da carga tributária, como induzido pela Constituição. Esse raciocínio nos leva à conclusão de há exigência constitucional implícita, no sentido de que um imposto somente pode ser cobrado daquela pessoa cuja capacidade contributiva seja revelada pelo acontecimento do fato imponível ou, nos casos de tributos vinculados, somente daquela pessoa a que a atuação estatal se refira de alguma maneira". ATALIBA, Geraldo; GIARDINO, Cléber. Revista de Direito Tributário, São Paulo: Malheiros, n. 34, p. 204.

84 DERZI, Misabel DE Abreu Machado. Praticidade. ICMS. Substituição tributária progressiva, "para frente". In:__ (Coord.). Construindo o Direito Tributário na Constituição. Belo Horizonte: Del Rey, 2004. p. 186.

${ }^{85}$ CARAZZA, Roque Antonio. ICMS. 10 ed. São Paulo: Malheiros, 2005, p. 225.

${ }^{86}$ Sobre a possibilidade da discussão de constitucionalidade de uma Emenda Constitucional, o pleno do STF, na ação direta de inconstitucionalidade n. 939-DF, dispôs que: "uma Emenda Constitucional, emanada, portanto, de Constituinte derivada, incidindo em violação a Constituição originária, pode ser declarada inconstitucional, pelo Supremo Tribunal Federal, cuja função precípua é de guarda da Constituição (art. 102, I, "a", da CF)".
} 
Ora, o art. $1^{\circ}$. da EC 03/93 é inconstitucional, porque atropela o princípio da segurança jurídica, em sua dupla manifestação: certeza do direito e proibição do arbítrio. Este princípio, aplicado ao Direito Tributário, exige que o tributo só nasça após a ocorrência real (efetiva) do fato imponível.

\section{Nesta mesma linha pondera PAULO DE BARROS CARVALHO ${ }^{87}$ :}

De modo diverso, na chamada substituição para frente, nutrida pela suposição de que determinado sucesso tributário haverá de realizar-se no futuro, o que justificaria uma exigência presente, as dificuldades jurídicas se multiplicam em várias direções, atropelando importantes valores constitucionais. Para atenuar os efeitos aleatórios dessa concepção de incidência, acena-se com um expediente compensatório ágil, que possa, a qualquer momento, ser acionado para recompor a integridade econômico financeira da pessoa atingida, falando-se até em lançamentos escriturais imediatamente lavrados nos livros próprios. Por esse modo se pretende legitimar, perante o ordenamento jurídico, a extravagante iniciativa de tributar eventos futuros, sobre os quais nada se pode adiantar.

[...]Tais considerações servem para registrar minha convicção no sentido de ser essa espécie de tributação maculada por vícios de inconstitucionalidade, tendo em vista a pretensão de se tributar "fato futuro", atropelando uma série de princípios constitucionais.

ALCIDES JORGE COSTA ${ }^{88}$, com toda sua autoridade sobre o assunto, também alinhouse aos opositores do instituto ao concluir:

A substituição para frente é outro equívoco. Se na substituição a obrigação já nasce tendo o substituto como sujeito passivo, é evidente que não se pode falar em substituto passivo de uma obrigação que não existe, nem se sabe se vai existir. E como ver algum vínculo, qualquer que seja ele, entre o substituto e um contribuinte inexistente?

Acresce que tributar fatos futuros conflita com a Constituição. Os problemas suscitados pelo parágrafo $7^{\circ}$. que a Emenda n. 3, de 17 de março de 1993, mandou acrescentar ao artigo 150 da Constituição serão apreciados em outro capítulo. O que se tributa é a capacidade atual, não a futura.

Ao que me parece, o parágrafo $7^{\circ}$. aqui questionado choca-se com o princípio da capacidade contributiva, com o princípio da igualdade e com o princípio da legalidade [...] Trata-se de antinomia real, isto é, de antinomia para a qual não há, no ordenamento jurídico, regra normativa de solução.

Do outro lado da balança, entre aqueles que pregam pela possibilidade de utilização do instituto, encontramos juristas importantes, como ALFREDO AUGUSTO BECKER ${ }^{89}$ que sobre o tema doutrinou:

[...] a criação do substituto legal tributário tanto é um fenômeno jurídico perfeitamente normal quanto é um processo técnico de criação do direito utilizado com muito mais frequência do que se imagina em todos os demais ramos do direito. O sujeito passivo da relação jurídica tributária, normalmente, deveria ser aquela determinada pessoa de cuja renda ou capital a hipótese de incidência é um fato-signo presuntivo. Entretanto, frequentemente, colocar esta pessoa no pólo negativo da relação jurídica tributária é

${ }^{87}$ CARVALHO, Paulo de Barros. Direito Tributário Linguagem e Método. 3. ed. São Paulo: Noeses, 2009, p. 651-653.

${ }^{88}$ COSTA, Alcides Jorge. ICMS e Substituição Tributária. Revista Dialética de Direito Tributário, n. 2, pp. 85 e ss.

${ }^{89}$ BECKER, Alfredo Augusto. Teoria geral do direito tributário. 5.ed. São Paulo: Noeses, 2010, p. 591. 
impraticável ou simplesmente criará maiores ou menores dificuldades para nascimento, vida e extinção destas relações. Por isto, nestas oportunidades, o legislador como solução emprega uma outra pessoa em lugar daquela e, toda vez que utiliza esta outra pessoa, cria o substituto legal tributário.

\section{Humberto Ávila alinha-se também àqueles que consideram a substituição tributária constitucional, mas desde que atendidos os seguintes requisitos de generalidade e não excessividade da base de cálculo ${ }^{90}$ :}

(a) a base de cálculo para a obrigação com a substituição corresponder à base de cálculo do fato que deva ocorrer posteriormente;

(b) a padronização for instrumento para a realização da igualdade geral, devendo corresponder aos elementos concretos manifestados pela média das operações efetivamente praticadas;

(c) a padronização promove satisfatoriamente a igualdade geral, o que só se verifica quando provoca efeito desigual de diminuta extensão (a desigualdade não é contínua nem considerável entre os contribuintes), alcance (a desigualdade não atinge um número expressivo de contribuintes) e qualidade (a desigualdade não provoca efeito de natureza direta, mas secundária relativamente aos direitos fundamentais de igualdade $\mathrm{e}$ liberdade).

\section{MARCo AurÉLIO GRECO, cuja doutrina serviu de fundamentação para o}

posicionamento da jurisprudência atual sobre o tema da substituição tributária, concluiu com base na análise de necessidade, adequação e proporcionalidade ${ }^{91}$ que:

\footnotetext{
${ }^{90}$ ÁVILA, Humberto. Substituição tributária e base de cálculo: os limites da padronização fiscal. Revista da Ajuris, v.32, n.100. Porto Alegre: Livraria do Advogado, 2005, p. 180.

${ }^{91}$ Assim doutrinou: "De qualquer modo, sublinhe-se que a criação do modelo da antecipação e a escolha, pelo legislador, da fase preliminar não podem ser aleatórias; a escolha só pode recair em eventos que apresentem, no plano fático, algum tipo de vinculação com o fato tributável a ocorrer posteriormente, e em determinado grau que permite prever, com razoável grau de certeza, sua ocorrência (elemento adequação) e na dimensão então prevista (princípio da proporcionalidade no critério da proibição do excesso).

Ou seja, como a relação é entre fase preliminar (momento da antecipação) e fase final (fato tributável) e como aquela deve se apresentar (para ser preliminar) como uma etapa, ou um meio para a obtenção da fase final (fato tributável) pode-se buscar, para analisar o tema no plano dos fatos, o mesmo conjunto de critérios que a Teoria Geral apresenta em se tratando da verificação da compatibilidade entre meios e fins e que também pode ser aplicado ao exame no plano da validade das normas. Este conjunto é formado pela reunião de três conceitos, singelamente designados de necessidade, adequação e proporcionalidade (ou proibição do excesso). Se bem examinarmos o tema da antecipação com substituição e esta formulação teórica, veremos que a essência destes três critérios pode ser aplicada à figura...

O primeiro consiste em verificar se aquele evento que foi considerado como fase preliminar para fins de antecipação atende ao requisito da necessidade em relação ao evento final (fato "gerador"); a fase preliminar será necessária se, inexistindo esta, não existirá o fato 'gerado'. Note-se que a relação a ser perquirida não é uma relação de causalidade entre ambas, por isso o requisito a ser verificado é da 'necessidade' e não da 'suficiência', ou seja, a fase não deixará de ser preliminar, e não perderá sua condição de servir para acarretar o recolhimento antecipado, pela circunstância de não ser suficiente (bastante em si) para acarretar o fato final. Ainda que outros elementos devam ser agregados para a ocorrência do fato 'gerador', o elemento 'necessidade' estará atendido com os requisitos acima.

O segundo consiste na verificação de adequação acima mencionada e por ele caberá verificar se aquele evento que se reputa preliminar já apresenta elementos que permitam prever com certo grau de certeza o evento final (o fato 'gerador'). É o que se encontra dentro do tempo 'presumido', utilizado pelo Constituinte no $§ 7^{\circ}$. examinado.

O terceiro é o conceito de proporcionalidade ou proibição do excesso, segundo o qual a dimensão pecuniária imposta no momento da antecipação deve ser proporcional à dimensão final que resultaria da ocorrência do fato tributável. Daí, em certas legislações estarem previstos levantamentos, pesquisas de mercado etc. como instrumentos para esta aferição que permita manter a proporcionalidade. E a proibição do excesso corresponde à cláusula explícita da devolução do valor recebido a maior".
} 
Em suma, não vejo incompatibilidade constitucional na figura examinada. Ao revés, a mais moderna doutrina do Direito Tributário nacional e estrangeiro sustenta sua validade. As dificuldades que sua interpretação e análise ensejam, ao invés de conduzirem a inconstitucionalidade, propõe, isto sim, um desafio para todos os aplicadores do Direito tributário, qual seja o de identificar os seus contornos e limites em função das peculiaridades de cada tributo e realidade econômica ou jurídica por ele atingida. ${ }^{92}$

Em que pese a mais abalizada doutrina citada, firmamos nossa posição de que em razão do princípio praticabilidade que a substituição tributária almeja atender, não se pode discutir sua constitucionalidade apenas considerando a capacidade contributiva ou legalidade, ou ainda segurança jurídica, sem a devida ponderação de todos os valores envolvidos.

\section{Como assevera Alessandro MENDES CARDOSO ${ }^{93}$ :}

Da mesma forma que não se pode classificar peremptoriamente as normas de praticidade como sempre inconstitucionais, a partir de um raciocínio formalista apegado exclusivamente na legalidade e tipicidade, em sentido inverso, não é possível justificar o uso abusivo dessas normas com o fundamento de que estas facilitam ou viabilizam a tributação.

A constitucionalidade da substituição tributária já foi discutida no leading case do Recurso Extraordinário 3.396-5/SP, interposto pelo Estado de São Paulo contra acórdão do Tribunal de Justiça de São Paulo, confirmatório de sentença pela qual declarava inconstitucional a antecipada exigência do fabricante, na qualidade de substituto tributário do ICMS incidente sobre os automóveis distribuídos à empresa concessionária e alusivo à operação subsequente de venda do bem ao consumidor final, ao fundamento de cuidar-se de exigência tributária despida de fato gerador.

O recurso foi provido, pois conforme ementado, o acórdão afastou-se do entendimento de que "A responsabilidade, como substituto, no caso, foi imposta, por lei, como medida de política fiscal, autorizada pela Constituição, não havendo que se falar em exigência tributária despida de fato gerador".

As principais objeções doutrinárias à substituição tributária, conforme relatamos supra, foram afastadas pelo Plenário do STF, com os seguintes fundamentos extraídos no voto do Ministro Relator Ilmar Galvão:

GRECO, Marco Aurelio. Substituição Tributária (Antecipação do Fato Gerador). 2a . ed. São Paulo: Malheiros, 2001, p. 5253.

92 Ibidem, p. 53.

${ }^{93}$ CARDOSO, Alessandro Mendes. A Responsabilidade do Substituto Tributário e os limites à Praticidade. Revista Tributária e de Finanças Públicas, n. 68. São Paulo: Revista dos Tribunais, 2006, p. 160. 
Não há falar-se, portanto, em violação do princípio da capacidade contributiva, visto que, nos impostos indiretos, como o ICMS, como é por demais sabido, conquanto o contribuinte de direito seja aquele obrigado, por lei, a recolher o tributo, é o adquirente ou consumidor final o contribuinte de fato. Esse é que vai ser atingido pelo ônus do imposto, haja, ou não, substituição tributária. A capacidade contributiva do consumidor é que é considerada.

Por igual se mostra descabida a alegação de ofensa ao princípio da nãocumulatividade, se no preço do produto passado do industrial para o varejista não se embute mais do que se embutiria na hipótese de tratar-se de operações regulares, seja, o tributo devido pela saída do bem do estabelecimento do industrial, mais a parcela incidente sobre o valor acrescido até sua entrega ao consumidor final.

De outra parte, cumpridos se acham, na substituição tributária, os princípios da legalidade e da tipicidade, conforme acima restou demonstrado, instituído que foi o regime, no Estado de São Paulo, por lei, com observância das normas ditadas pela Constituição e pela lei complementar que a regulamentou, com exaustão de todos os aspectos legitimadores da exação, com especificidade tão-somente quanto ao fato gerador e à respectiva base de cálculo, que serão adiante apreciados.

Quanto ao confisco, não é difícil demonstrar a impossibilidade de sua ocorrência, tendo em vista o reembolso, pelo substituto, do imposto pago, quando do recebimento do preço das mãos do substituído; reembolsando-se esse, de sua vez, ao receber o preço final das mãos do consumidor.

$[\ldots]$

Não é difícil perceber que a substituição tributária, em operações subsequentes, com é o caso dos autos, convém às partes envolvidas na operação tributada: ao Fisco, por simplificar o trabalho de fiscalização, reduzido que fica ao pequeno número de empresas montadoras de veículos existentes no país; à montadora, por permitir um controle do preço final pelo qual os seus produtos são entregues ao consumidor final, preço esse de ordinário sugerido ao revendedor pelo fabricante; ao concessionário revendedor, por exonera-lo de toda preocupação de ordem tributária, desobrigado que fica do recolhimento do ICMS sobre os veículos comercializados; e, por fim, ao consumidor, por dar-lhe a certeza de que o preço pago corresponde ao recomendado pelo fabricante. ${ }^{94}$

Após esse acórdão da mais alta corte no país, não ocorreram mais questionamentos sobre a constitucionalidade da substituição, até que os Estados, por meio do CONFAZ, editaram o convênio n. 13/97.

Neste convênio, apesar de o objetivo declarado foi atender a "necessidade de harmonizar os procedimentos a serem adotados pelas unidades federadas com referência às normas atinentes à substituição tributária do ICMS", visava principalmente prevenir a guerra fiscal, em razão dos benefícios que alguns Estados vinham concedendo na forma de créditos aos seus contribuintes, como meio de restituição de ICMS cobrado a maior em razão da base de cálculo presumida ter sido superior ao valor efetivo da operação.

Como solução para o problema foi dada uma interpretação literal ao disposto no $\S 7^{\circ}$. do art. 150 da $\mathrm{CF} / 88$, pela qual só caberia restituição quando não ocorresse o fato gerador presumido, conforme cláusula segunda do convênio ICMS 13 de 21 de março de 1997:

${ }^{94}$ STF. RExt 213396 / SP, Relator: Min. ILMAR GALVÃO, Tribunal Pleno, Julgamento: 02.08.1999. 
Cláusula segunda - Não caberá a restituição ou cobrança complementar do ICMS quando a operação ou prestação subsequente à cobrança do imposto, sob a modalidade da substituição tributária, se realizar com valor inferior ou superior àquele estabelecido com base no artigo $8^{\circ}$ da Lei complementar 87 , de 13 de setembro de 1996.

Esta cláusula segunda do convênio foi objeto da Ação Direta de Inconstitucionalidade ADIN n. 1851-4/AL, proposta pela Confederação Nacional do Comércio - CNC, na qual o STF rejeitou a arguição de inconstitucionalidade, com a seguinte ementa:

EMENTA: TRIBUTÁRIO. ICMS. SUBSTITUIÇÃO TRIBUTÁRIA. CLÁUSULA SEGUNDA DO CONVÊNIO 13/97 E $\S \S 6^{\circ}$ E $7^{\circ}$. DO ART. 498 DO DECRETO N. 35245/91 (REDAÇÃO DO ART. $1^{\circ}$. DO DECRETO N. 37.406/98), DO ESTADO DE ALAGOAS. ALEGADA OFENSA AO $\S 7^{\circ}$. DO ART. 150 DA CF (REDAÇÃO DA EC N. 3/93) E AO DIREITO DE PETIÇÃO E DE ACESSO AO JUCIÁRIO.

Convênio que objetivou prevenir guerra fiscal resultante de eventual concessão do benefício tributário representado pela restituição do ICMS cobrado a maior quando a operação final for de valor inferior ao do fato gerador presumido. Irrelevante que não tenha sido subscrito por todos os Estados, se não se cuida de concessão de benefício (LC n. 24/75, art $2^{\circ}$., inc. $2^{\circ}$.). Impossibilidade de exame, nesta edição do decreto, que tem natureza regulamentar.

A EC n. 03/93, ao introduzir ao art. 150 da CF/88 o $§ 7^{\circ}$, aperfeiçoou o instituto, já previsto em nosso sistema jurídico tributário, ao delinear a figura do fato gerador presumido e ao estabelecer a garantia de reembolso preferencial e imediato do tributo pago mesmo quando não verificado o mesmo fato a final. A circunstância de exigência antecipada do tributo, dado tratar-se de sistema instituído pela própria Constituição, encontrando-se regulamentado por Lei complementar que, para definir-lhe a base de cálculo, se valeu de critério de estimativa que a aproxima o mais possível da realidade.

A Lei complementar, por final, definiu o aspecto do fato gerador presumido como sendo a saída da mercadoria do estabelecimento do contribuinte substituto, não deixando margem para cogitar-se de momento diverso, no futuro, na conformidade, aliás, do previsto no art. 114 do CTN, que tem o fato gerador da obrigação principal como a situação definida em Lei como necessária e suficiente à sua ocorrência.

O fato gerador presumido, por isso mesmo, não é provisório, mas definitivo, não dando ensejo à restituição ou complementação do imposto pago, senão, no primeiro caso, na hipótese de sua realização final.

Admitir o contrário valeria por despojar-se o instituto das vantagens que determinaram a sua concepção e adoção, como a redução, a um só tempo, da máquina fiscal e da evasão físcal a dimensões mínimas, propiciando, portanto maior comodidade, economia, eficiência e celeridade às atividades de tributação e arrecadação $0^{95}$.

Neste acórdão, ao ponderar a praticabilidade da substituição com outros princípios, entendeu a Corte que a presunção do fato presumido é constitucional e a base de cálculo presumida, por manter uma relação de razoabilidade e proporcionalidade com os valores efetivos, é válida sem se exigir eventuais devoluções do ICMS corresponde à diferença entre ela e o valor real da operação.

\footnotetext{
${ }^{95}$ STF. ADIN N. 1.851-4/AL. Tribunal Pleno. Min. Relator Ilmar Galvão. j. 08.05.02.
} 
Em primeiro lugar a substituição tributária, como medida ditada em nome da praticabilidade, não rompe com a legalidade, por ter havido permissão constitucional expressa pelo art. $150, \S 7^{\circ}$., juntamente com a definição da base de cálculo pela lei complementar $n$. $87 / 96$.

Em segundo lugar, o STF entendeu que a presunção de que ocorrida a venda para o comerciante, ocorrerá a venda para o consumidor final é relativa, de tal sorte, que não ocorrendo a quantia paga a priori como imposto do fato presumido, será restituído. Como já ventilamos neste estudo, a utilização de presunções relativas é permitida e, por várias razões, são necessárias em determinadas situações.

Por fim, o STF entendeu que se a lei complementar ao regulamentar a base de cálculo presumida "se valeu de critério de estimativa que a aproxima o mais possível da realidade", estaríamos diante de uma presunção absoluta não havendo mais direito à restituição, mas também não haveria mais cobrança complementar, ou seja, se a base presumida realmente corresponder à média dos valores efetivos praticados, ocorrerão ocasiões favoráveis e prejudiciais, tanto para o contribuinte, quanto para o Estado.

Mas e se a base de cálculo presumida não corresponder a realidade? Eis, o ponto crucial! A Corte Suprema argumenta que a praticabilidade (comodidade, economia, eficiência e celeridade às atividades de tributação e arrecadação) não justifica a restituição, ou a complementação. Isso está expresso no voto do Ministro Ilmar Galvão ${ }^{96}$ :

Não seria, realmente de admitir que, diante desses efeitos práticos, decisivos para
adoção da substituição tributária, viesse o legislador a criar mecanismo capaz de
inviabilizar a utilização do valioso instituto, como a compensação de eventuais
excessos ou faltas, em face do valor real da última operação, determinando o retorno
da apuração mensal do tributo, prática que justamente teve por escopo obviar (grifo
nosso).

Como também no voto do Ministro Sepúlveda Pertence ${ }^{97}$ :

A Emenda Constitucional n. 03/93, de que resultou o $\S 7^{\circ}$. do art. 150, veio para dar ao fisco um mecanismo eficaz para determinado tipo de circulação econômica e fez a ressalva. Agora, se esta ressalva é interpretada de modo a inviabilizar o instrumento fiscal que se autorizou, a meu ver, o que se está é negando a efetividade no sentido principal.

Ou ainda no voto do Ministro Sydney Sanches ${ }^{98}$ :

Bem ou mal, o o $\S 7^{\circ}$. do art. 150 da CF constitucionalizou a substituição tributária, que a antiga legislação infraconstitucional permitia nunca foi declarada

\footnotetext{
${ }^{96}$ STF. ADIN N. 1.851-4/AL. Tribunal Pleno. Min. Relator Ilmar Galvão. j. 08.05.02.

${ }^{97}$ STF. ADIN N. 1.851-4/AL. Tribunal Pleno. Min. Relator Ilmar Galvão. j. 08.05.02.

${ }^{98}$ STF. ADIN N. 1.851-4/AL. Tribunal Pleno. Min. Relator Ilmar Galvão. j. 08.05.02.
} 
inconstitucional por esta Corte. E o fez de modo a só assegurar a restituição da quantia paga, caso não se realize e o fato gerador presumido. Chegou a essa solução, pela praticidade que a substituição viabiliza, no que concerne à arrecadação (grifei).

Se se entender que, tanto a complementação quanto a restituição, decorrente do valor da operação subsequente, devem ser contempladas, então estará esvaziado o próprio instituto da substituição, em seus razoáveis objetivos.

Até no voto vencido do Ministro Carlos Velloso, o ponto fulcral está na base de cálculo:

Conforme vimos, na substituição tributária 'para frente', é assegurada a restituição da quantia paga, caso não se realize o fato gerador presumido. Ora, se o fato gerador tem, na base de cálculo, a sua expressão valorativa, ou a sua dimensão material, força é convir que o fato gerador se realiza nos termos dessa sua dimensão material, nem mais, nem menos. ${ }^{99}$

Para contextualizar esse entendimento firmado no acórdão, é importante destacar que à época do julgamento, a substituição tributária somente era aplicada às mercadorias com preços fixados ou tabelados (pelo fabricante ou pelo governo), não sendo verificado na prática, distorções nos preços praticados no mercado, como o próprio Ministro Ilmar Galvão justificou no seu voto:

Trata-se de regime a quem na prática, somente são submetidos produtos com preço de revenda final previamente fixado pelo fabricante ou importador, como é o caso de veículos e cigarros; ou tabelados pelo Governo, como acontecia até recentemente com os combustíveis, e como acontece com a energia elétrica etc; razão pela qual só eventualmente poderão verificar-se excessos de tributação. ${ }^{100}$

Hoje essa situação mudou! Os fiscos estaduais rapidamente perceberam que poderiam utilizar essa preciosa ferramenta como uma panaceia para toda e qualquer operação de mercadorias, simplesmente como medida de comodidade arrecadatória, sem considerar critérios de proporcionalidade e razoabilidade para sua instituição. Eis aí a razão do problema: seu uso não é ilimitado!

Embora o STF tenha decidido pela constitucionalidade da substituição tributária, o julgamento ocorreu em sede de controle concentrado de constitucionalidade, tendo por objeto a análise de compatibilidade abstrata e em tese do instituto da substituição tributária com a Carta Magna.

Não foi analisado pela Corte nenhum caso concreto de aplicação da substituição, o que importa dizer que ela "nada decidiu sobre o seu conteúdo e os seus limites: nenhuma pauta

\footnotetext{
${ }^{99}$ STF. ADIN N. 1.851-4/AL. Tribunal Pleno. Min. Relator Ilmar Galvão. j. 08.05.02.

${ }^{100}$ STF. ADIN N. 1.851-4/AL. Tribunal Pleno. Min. Relator Ilmar Galvão. j. 08.05.02.
} 
fiscal específica foi analisada; nenhum critério foi estabelecido; nenhum limite foi questionado". ${ }^{101}$

Neste caso, como assevera MISABEL DERZI ${ }^{102}$ :

Ora, em sede de controle abstrato, é possível ao Supremo Tribunal Federal dizer em tese, se uma presunção é razoável e proporcional à média dos casos. [...] Outra questão diferente se põe, em cada caso concreto, em relação a todos aqueles contribuintes que não se encontram dentro daquela média razoável e que, comprovadamente, alienaram a mercadoria por preço inferior àquele estimado antecipadamente.

Se a base presumida não corresponder à média, duas situações poderão ocorrer: (i) a base presumida é inferior ao valor médio das operações: situação prejudicial ao Estado e, consequentemente, a todos os cidadãos; (ii) a base presumida é superior ao valor médio das operações: situação prejudicial à classe de contribuintes que praticam aquela operação. No nosso modo de entender nenhuma das duas situações está consentânea com os valores imbricados pelos valores constitucionais e, portanto, requerem o ajuste do valor presumido o mais rapidamente possível, para que a substituição, nestes casos, não fique eivada de inconstitucionalidade.

A análise da temática da substituição tributária, conforme se depreende, está em verificar se não está ocorrendo desvirtuamento na aplicação do instituto pela legislação dos Estados e Distrito Federal, mormente na fixação dos valores presumidos de base de cálculo.

A tarefa de disciplinar a substituição tributária foi reservada à lei complementar, por prescrição do art. $155, \S 2^{\circ}$., XII, “b” da Constituição Federal de 1988:

Art. 155. Compete aos Estados e ao Distrito Federal instituir impostos sobre: [...]II - operações relativas à circulação de mercadorias e sobre prestações de serviços de transporte interestadual e intermunicipal e de comunicação, ainda que as operações e as prestações se iniciem no exterior; [...]

$\$ \mathbf{2}^{\circ} \mathrm{O}$ imposto previsto no inciso II atenderá ao seguinte:[...]

XII - cabe à lei complementar: [...]

b) dispor sobre substituição tributária;

A lei complementar n. 87/96, no art. $8^{\circ}$., regulamentou a forma de apuração da base de cálculo ${ }^{103}$ nas operações sujeitas à substituição tributária, estabelecendo as seguintes regras:

101 ÁVILA, Humberto. Substituição tributária e base de cálculo: os limites da padronização fiscal. Revista da Ajuris, v.32, n.100. Porto Alegre: Livraria do Advogado, 2005, p. 171.

102 DERZI, Misabel DE ABReu MACHADO. Praticidade. ICMS. Substituição tributária progressiva, "para frente". In:___ (Coord.). Construindo o Direito Tributário na Constituição. Belo Horizonte: Del Rey, 2004. p. 174.

${ }^{103}$ Lei complementar n. 87/96: Art. $8^{\circ} \mathrm{A}$ base de cálculo, para fins de substituição tributária, será:

I - em relação às operações ou prestações antecedentes ou concomitantes, o valor da operação ou prestação praticado pelo contribuinte substituído; 


\begin{tabular}{|l|l|}
\hline $\begin{array}{l}1^{\mathrm{a}} . \\
\text { REGRA: } \\
\text { (Obrigatória) }\end{array}$ & $\begin{array}{l}\text { Mercadoria com preço final a consumidor único ou } \\
\text { máximo fixado por órgão público competente. }\end{array}$ \\
\hline Base Cálculo: & $\underline{\text { SERÁ ESTE PREÇO FIXADO }}$ \\
\hline
\end{tabular}

\begin{tabular}{|l|l|}
\hline $\begin{array}{l}2^{\mathrm{a}} . \quad \text { REGRA: } \\
(\text { Facultativa })\end{array}$ & $\begin{array}{l}\text { Mercadoria com preço final a consumidor sugerido pelo } \\
\text { fabricante ou importador. }\end{array}$ \\
\hline Base Cálculo: & PODERÁ ser este preço sugerido \\
\hline
\end{tabular}

\begin{tabular}{|l|l|}
\hline $\begin{array}{l}3^{\mathrm{a}} . \\
\text { (GEGérica) }\end{array}$ & Utilizada quando não for utilizada a $1^{\mathrm{a}}$., nem a $2^{\mathrm{a}}$. Regra. \\
\hline Base Cálculo: & $\begin{array}{l}\text { Somatório do valor da operação própria realizada pelo } \\
\text { substituto, com os valores de seguro, frete e de outros } \\
\text { encargos, mais a margem de valor agregado, inclusive } \\
\text { lucro, relativa às operações subsequentes. }\end{array}$ \\
\hline Margem: & $\begin{array}{l}\text { Estabelecida com base em preços usualmente praticados no } \\
\text { mercado considerado, obtidos por levantamento, ainda que por } \\
\text { amostragem ou através de informações e outros elementos } \\
\text { fornecidos por entidades representativas dos respectivos setores, } \\
\text { adotando-se a média ponderada dos preços coletados, devendo os } \\
\text { critérios para sua fixação ser previstos em lei. }\end{array}$ \\
\hline
\end{tabular}

II - em relação às operações ou prestações subseqüentes, obtida pelo somatório das parcelas seguintes:

a) o valor da operação ou prestação própria realizada pelo substituto tributário ou pelo substituído intermediário;

b) o montante dos valores de seguro, de frete e de outros encargos cobrados ou transferíveis aos adquirentes ou tomadores de serviço;

c) a margem de valor agregado, inclusive lucro, relativa às operações ou prestações subseqüentes.

$\S 1^{\circ} \mathrm{Na}$ hipótese de responsabilidade tributária em relação às operações ou prestações antecedentes, o imposto devido pelas referidas operações ou prestações será pago pelo responsável, quando:

I - da entrada ou recebimento da mercadoria ou do serviço;

I - da entrada ou recebimento da mercadoria, do bem ou do serviço;

II - da saída subseqüente por ele promovida, ainda que isenta ou não tributada;

III - ocorrer qualquer saída ou evento que impossibilite a ocorrência do fato determinante do pagamento do imposto.

$\S 2^{\circ}$ Tratando-se de mercadoria ou serviço cujo preço final a consumidor, único ou máximo, seja fixado por órgão público competente, a base de cálculo do imposto, para fins de substituição tributária, é o referido preço por ele estabelecido.

$\S 3^{\circ}$ Existindo preço final a consumidor sugerido pelo fabricante ou importador, poderá a lei estabelecer como base de cálculo este preço.

$\S 4^{\circ}$ A margem a que se refere a alínea c do inciso II do caput será estabelecida com base em preços usualmente praticados no mercado considerado, obtidos por levantamento, ainda que por amostragem ou através de informações e outros elementos fornecidos por entidades representativas dos respectivos setores, adotando-se a média ponderada dos preços coletados, devendo os critérios para sua fixação ser previstos em lei.

$\S 5^{\circ} \mathrm{O}$ imposto a ser pago por substituição tributária, na hipótese do inciso II do caput, corresponderá à diferença entre o valor resultante da aplicação da alíquota prevista para as operações ou prestações internas do Estado de destino sobre a respectiva base de cálculo e o valor do imposto devido pela operação ou prestação própria do substituto.

$\S 6$ 으 Em substituição ao disposto no inciso II do caput, a base de cálculo em relação às operações ou prestações subseqüentes poderá ser o preço a consumidor final usualmente praticado no mercado considerado, relativamente ao serviço, à mercadoria ou sua similar, em condições de livre concorrência, adotando-se para sua apuração as regras estabelecidas no $§ 4^{\circ}$ deste artigo. 


\begin{tabular}{|c|c|}
\hline $\begin{array}{l}4^{\mathrm{a}} . \quad \text { REGRA: } \\
\text { (Facultativa) }\end{array}$ & Utilizada em substituição à $3^{a}$. Regra. \\
\hline Base Cálculo: & $\begin{array}{l}\text { Preço a consumidor final usualmente praticado no } \\
\text { mercado considerado, em condições de livre } \\
\text { concorrência. }\end{array}$ \\
\hline Preço: & $\begin{array}{l}\text { Estabelecido com base em preços usualmente praticados no } \\
\text { mercado considerado, obtidos por levantamento, ainda que } \\
\text { por amostragem ou através de informações e outros } \\
\text { elementos fornecidos por entidades representativas dos } \\
\text { respectivos setores, adotando-se a média ponderada dos } \\
\text { preços coletados, devendo os critérios para sua fixação ser } \\
\text { previstos em lei. }\end{array}$ \\
\hline
\end{tabular}


Para as mercadorias que tiverem seu preço final a consumidor, único ou máximo, fixado por órgão público competente, a $1^{\mathrm{a}}$ regra obriga a base de cálculo presumida ser o preço fixado. Ora, se o preço é fixado, outros preços não existirão, razão pela qual ao se utilizar este valor como base de cálculo, com absoluta certeza não haverá distorções entre o preço efetivo e o presumido.

No caso de mercadorias que têm o preço final a consumidor sugerido pelo fabricante ou importador, a lei poderá utilizá-lo como base de cálculo presumida. A razão por esta opcionalidade foi a prudência do legislador, isto é, o valor sugerido poderá ser usado "se e enquanto refletir o valor de venda das mercadorias na maior parte dos casos, sem discrepâncias regulares entre o valor presumido e o real para um número muito grande de casos. Se isso ocorrer, a utilização do preço final sugerido pelo fabricante, embora em tese permitida, será concretamente incompatível com a CF/88". ${ }^{104}$

Não havendo nem preços fixados e nem preços sugeridos, utiliza-se a $3^{\mathrm{a}}$. Regra, pela qual a base de cálculo será obtida pela soma: do valor da operação própria realizada pelo substituto tributário; dos valores de seguro, frete e outros encargos; e do valor da margem de valor agregado, inclusive lucro, relativos às operações ou prestações subsequentes, ou a $4^{\mathrm{a}}$. Regra, na qual a base de cálculo corresponderá ao preço praticado no mercado, considerado em condições de livre concorrência.

Tanto a margem de valor agregado da $3^{\mathrm{a}}$. regra, como o preço praticado no mercado da $4^{\mathrm{a}}$. regra, são obtidos por levantamento, quer seja por amostragem ou por elementos fornecidos por entidades representativas dos respectivos setores, pela média ponderada dos preços coletados, devendo os critérios para sua fixação ser previstos em lei ordinária dos Estados.

A fixação da margem de valor agregado é um ponto chave na apuração da base de cálculo presumida, pois uma margem mal dimensionada a invalidará irremediavelmente. Ao disciplinar que os preços sejam a média ponderada, na qual serão considerados os números de ocorrências de cada preço, e não simplesmente a média aritmética, andou bem o legislador essa média refletir realmente o valor usualmente praticado no mercado considerado.

Impende ressaltar que a incumbência dada pela lei complementar de realizar o levantamento de preço é da administração fazendária e, portanto, nada mais natural que o ônus de demonstrar a compatibilidade dos valores presumidos com a média ponderada dos preços usualmente praticados no mercado também seja dela, ou:

104 ÁVILA, Humberto. Substituição tributária e base de cálculo: os limites da padronização fiscal. Revista da Ajuris, v.32, n.100. Porto Alegre: Livraria do Advogado, 2005, p. 182. 
Não basta, portanto, que a autoridade simplesmente afirme que os valores de pauta correspondem à média ou que o preço máximo ao consumidor sugerido pelo estabelecimento industrial não é inferior ao praticado no mercado. A autoridade precisa juntar provas demonstrando isso, pois a Lei complementar atribui a ela essa obrigação ${ }^{105}$.

\section{No Estado de São Paulo, a forma de apuração base de cálculo nas operações sujeitas} à substituição tributária está prevista ${ }^{106}$ nos seguintes artigos 40-A e seguintes da lei n. 6374/89.

\footnotetext{
${ }^{105}$ Ibidem, p. 183.

${ }^{106}$ Lei n. 6374/89: Artigo 40-A - No caso de sujeição passiva por substituição com retenção antecipada do imposto, a base de cálculo será o preço final a consumidor, único ou máximo, autorizado ou fixado por autoridade competente.

Parágrafo único - Tratando-se de veículo automotor novo importado, ao preço único ou máximo de venda deverão ser acrescidos os valores relativos aos acessórios colocados no veículo pelo sujeito passivo por substituição.

Artigo 41 - Na falta de preço final a consumidor, único ou máximo, autorizado ou fixado por autoridade competente, a base de cálculo do imposto para fins de substituição tributária com retenção antecipada do imposto será o preço praticado pelo sujeito passivo, incluídos os valores correspondentes a frete, carreto, seguro, impostos e outros encargos transferíveis ao adquirente, acrescido do valor resultante da aplicação de percentual de margem de valor agregado estabelecido conforme disposto pela legislação em cada caso

Parágrafo único - Quando existir preço final a consumidor sugerido pelo fabricante ou importador, adotar-se-á esse preço como base de cálculo para retenção do imposto por substituição tributária, desde que:

1 - a entidade representativa do fabricante ou importador apresente pedido formal, nos termos de disciplina estabelecida pela Secretaria da Fazenda, devidamente documentado por cópias de Notas Fiscais e demais elementos que possam comprovar o preço praticado;

2 - na hipótese de deferimento do pedido referido no item 1, o preço sugerido será aplicável somente após ser editada a legislação correspondente.
}

Artigo 42 - Na impossibilidade de inclusão dos valores referentes a frete, seguro ou outro encargo na base de cálculo a que se refere o "caput" do artigo 41, por serem esses valores desconhecidos do sujeito passivo por substituição, o pagamento do imposto sobre as referidas parcelas deverá ser efetuado pelo contribuinte substituído que receber a mercadoria diretamente do sujeito passivo por substituição, nos termos do artigo 280, devendo tal condição ser indicada no documento fiscal por este emitido.

Parágrafo único - O disposto neste artigo não se aplica na hipótese de ter sido aplicado percentual de margem de valor agregado específico para operações sem a inclusão do valor do frete na base de cálculo da retenção.

Artigo 43 - Em substituição ao disposto no artigo 41, a Secretaria da Fazenda poderá fixar como base de cálculo da substituição tributária, com retenção antecipada do imposto, a média ponderada dos preços a consumidor final usualmente praticados no mercado considerado, apurada por levantamento de preços, ainda que por amostragem ou por meio de dados fornecidos por entidades representativas dos respectivos setores.

$\S 1^{\circ}$ - O levantamento de preços a que se refere este artigo:

1 - deverá apurar, no mínimo, o preço de venda à vista no varejo, incluindo o frete, seguro e demais despesas cobradas do adquirente;

2 - não deverá considerar os preços de promoção, bem como aqueles submetidos a qualquer tipo de comercialização privilegiada;

3 - poderá ser promovido pela Secretaria da Fazenda ou, a seu critério, por entidade representativa do setor que realiza operações ou prestações sujeitas à substituição tributária;

4 - poderá ser adotado pela Secretaria da Fazenda com base em pesquisas já realizadas por instituto de pesquisa de mercado de reputação idônea.

$\S 2^{\circ}$ - Na hipótese de o levantamento de preços ser promovido por entidade representativa de setor, este deverá ser realizado por instituto de pesquisa de mercado de reputação idônea, desvinculado da referida entidade, devendo ser encaminhado à Secretaria da Fazenda para efeitos de subsidiar a fixação da base de cálculo do imposto, acompanhado de:

1 - relatório detalhado sobre a metodologia utilizada;

2 - provas que demonstrem a prática dos preços pesquisados pelo mercado

$\S 3^{\circ}$ - Para fins do disposto neste artigo, a Secretaria da Fazenda poderá utilizar os dados fornecidos por contribuintes de um determinado setor da economia, em atendimento a obrigações acessórias fixadas pela legislação.

Artigo 44 - Para fins de estabelecimento do percentual de margem de valor agregado a que se refere o artigo 41, o levantamento de preços previsto no artigo 43 deverá apurar também:

I - o preço de venda à vista no estabelecimento fabricante ou importador, incluindo o ICMS da operação própria, IPI, frete, seguro e demais despesas cobradas do destinatário, excluído o valor do ICMS relativo à substituição tributária; II - o preço à vista no estabelecimento atacadista, incluindo o ICMS da operação própria, frete, seguro e demais despesas cobradas do destinatário, excluído o valor do ICMS relativo à substituição tributária. $\S 1^{\circ}$ - O percentual de margem de valor agregado será fixado pela Secretaria da Fazenda com base nos preços obtidos pelo levantamento, estabelecendo-se a relação percentual entre os valores apurados relativamente:

1 - ao item 1 do $\S 1^{\circ}$ do artigo 43 e o inciso I;

2 - ao item 1 do $\S 1^{\circ}$ do artigo 43 e o inciso II. 
Estes artigos praticamente reproduzem as regras disciplinadas pela Lei complementar n. 87/96.

A lei estadual admite a utilização de preço sugerido pelo fabricante ou importador como base de cálculo, mas para salvaguardar a compatibilidade deste preço sugerido com o preço usualmente praticado no mercado, exige-se: (1) a entidade representativa do fabricante ou importador apresente pedido formal, nos termos de disciplina estabelecida pela Secretaria da Fazenda, devidamente documentado por cópias de Notas Fiscais e demais elementos que possam comprovar o preço praticado; (2) na hipótese de deferimento do pedido referido no item 1, o preço sugerido será aplicável somente após ser editada a legislação correspondente.

Ocorre que o Coordenador da Administração Tributária expediu a Portaria CAT 16 de 23 de janeiro de 2009, criando uma regra intermediária, enquanto os levantamentos dos preços de mercado não forem realizados, que assim prescreve:

Portaria CAT16/09. Artigo $1^{\circ}$. - A base de cálculo para fins de retenção e pagamento do imposto relativo às saídas subsequentes das mercadorias arroladas nos artigos 313A a 313-Z20 do RICMS, com destino a estabelecimento localizado em território paulista, será o preço praticado pelo sujeito passivo, incluídos os valores correspondentes a frete, carreto, seguro, impostos e outros encargos transferíveis ao adquirente, acrescido do valor adicionado calculado mediante a multiplicação do preço praticado pelo Índice de Valor Adicionado Setorial - IVA-ST indicado no

$\S 2^{\circ}$ - Poderão ser adotados percentuais de margem de valor agregado ou preço final a consumidor fixados em acordo celebrado pelo Estado de São Paulo com outras unidades da Federação, com observância do disposto em lei complementar relativa à matéria. 
Anexo Único, conforme hipótese prevista no artigo $43, \S 3^{\circ}$, c/c o artigo $44^{107}$, do RICMS ${ }^{108}$.

\section{$\S 1^{\circ}$ - O disposto nesta portaria somente se aplica quando não houver:}

1 - média ponderada dos preços a consumidor final usualmente praticados no mercado, apurada por levantamento de preços aprovado e divulgado pela Secretaria da Fazenda, conforme hipótese prevista no artigo 43, § 2 , do RICMS;

2 - percentual de margem de valor agregado apurado por levantamento de preços aprovado e divulgado pela Secretaria da Fazenda, conforme hipótese prevista no artigo 41, caput, do RICMS;

3 - preço final a consumidor, único ou máximo, autorizado ou fixado por autoridade competente e divulgado pela Secretaria da Fazenda, conforme hipótese prevista no artigo 40-A do RICMS;

4 - preço final a consumidor, sugerido pelo fabricante ou importador, aprovado e divulgado pela Secretaria da Fazenda, conforme hipótese prevista no artigo 41, parágrafo único, do RICMS;

${ }^{107}$ RICMS- Decreto 45.590/00 - Artigo 43 - Em substituição ao disposto no artigo 41, a Secretaria da Fazenda poderá fixar como base de cálculo da substituição tributária, com retenção antecipada do imposto, a média ponderada dos preços a consumidor final usualmente praticados no mercado considerado, apurada por levantamento de preços, ainda que por amostragem ou por meio de dados fornecidos por entidades representativas dos respectivos setores.

$\S 1^{\circ}$ - O levantamento de preços a que se refere este artigo:

1 - deverá apurar, no mínimo, o preço de venda à vista no varejo, incluindo o frete, seguro e demais despesas cobradas do adquirente;

2 - não deverá considerar os preços de promoção, bem como aqueles submetidos a qualquer tipo de comercialização privilegiada;

3 - poderá ser promovido pela Secretaria da Fazenda ou, a seu critério, por entidade representativa do setor que realiza operações ou prestações sujeitas à substituição tributária;

4 - poderá ser adotado pela Secretaria da Fazenda com base em pesquisas já realizadas por instituto de pesquisa de mercado de reputação idônea.

$\S 2^{\circ}$ - Na hipótese de o levantamento de preços ser promovido por entidade representativa de setor, este deverá ser realizado por instituto de pesquisa de mercado de reputação idônea, desvinculado da referida entidade, devendo ser encaminhado à Secretaria da Fazenda para efeitos de subsidiar a fixação da base de cálculo do imposto, acompanhado de:

1 - relatório detalhado sobre a metodologia utilizada;

2 - provas que demonstrem a prática dos preços pesquisados pelo mercado.

$\S 3^{\circ}$ - Para fins do disposto neste artigo, a Secretaria da Fazenda poderá utilizar os dados fornecidos por contribuintes de um determinado setor da economia, em atendimento a obrigações acessórias fixadas pela legislação.

Artigo 44 - Para fins de estabelecimento do percentual de margem de valor agregado a que se refere o artigo 41, o levantamento de preços previsto no artigo 43 deverá apurar também:

I - o preço de venda à vista no estabelecimento fabricante ou importador, incluindo o ICMS da operação própria, IPI, frete, seguro e demais despesas cobradas do destinatário, excluído o valor do ICMS relativo à substituição tributária; II - o preço à vista no estabelecimento atacadista, incluindo o ICMS da operação própria, frete, seguro e demais despesas cobradas do destinatário, excluído o valor do ICMS relativo à substituição tributária. $\S 1^{\circ}$ - O percentual de margem de valor agregado será fixado pela Secretaria da Fazenda com base nos preços obtidos pelo levantamento, estabelecendo-se a relação percentual entre os valores apurados relativamente:

1 - ao item 1 do $\S 1^{\circ}$ do artigo 43 e o inciso I;

2 - ao item 1 do $\S 1^{\circ}$ do artigo 43 e o inciso II.

$\S 2^{\circ}$ - Poderão ser adotados percentuais de margem de valor agregado ou preço final a consumidor fixados em acordo celebrado pelo Estado de São Paulo com outras unidades da Federação, com observância do disposto em lei complementar relativa à matéria.

${ }^{108}$ Exemplos de IVA-ST do Anexo Único:

\begin{tabular}{|l|l|}
\hline Setor & IVA-ST \\
\hline Medicamentos & $68,59 \%$ \\
\hline Bebida alcoólica, exceto cerveja e chope & $123,87 \%$ \\
\hline Perfumaria & $177,19 \%$ \\
\hline Higiene Pessoal & $177,19 \%$ \\
\hline Ração animal - tipo "pet" & $59,70 \%$ \\
\hline$[\ldots]$ & {$[\ldots]$} \\
\hline
\end{tabular}


5 - sido adotado percentual de margem de valor agregado ou preço final a consumidor fixados em acordo celebrado pelo Estado de São Paulo com outras unidades da Federação, conforme hipótese prevista no artigo 44, § $2^{\circ}$, do RICMS. (Grifo Nosso)

Este ato administrativo foi positivado no Regulamento do ICMS - RICMS, pelo art. 313:

RICMS- Decreto 45.590/00 - Artigo 313 - Para determinação da base de cálculo, em caso de inexistência do preço final a consumidor, único ou máximo, autorizado ou fixado por autoridade competente, ou do preço final a consumidor sugerido pelo fabricante ou importador, aprovado e divulgado pela Secretaria da Fazenda, o percentual de margem de valor agregado previsto no artigo 41 será o Índice de Valor Adicionado Setorial - IVA-ST, calculado e divulgado pela Secretaria da Fazenda com base nas informacões prestadas pelos contribuintes. (Grifo nosso)

O Estado de São Paulo e muitos outros Estados, percebendo que a substituição tributária é uma ferramenta muito valiosa ao permitir antecipar o recolhimento do imposto no começo da cadeia produtiva, ao invés de só recebê-lo na venda de varejo e facilitar a fiscalização contra a evasão, transferindo a obrigação tributária para o contribuinte que oferece melhores condições para o seu cumprimento, rapidamente alargaram sua abrangência praticamente a quase todos os tipos de produtos e não somente àqueles com preço de revenda fixado pelo fabricante ou por órgão público.

Ocorre que assim procedendo, só poderia estabelecer a margem de valor agregado ou preço a consumidor final, após os levantamentos de preços usualmente praticados no mercado, com base na média ponderada dos preços coletados de acordo com critérios previstos em lei, conforme determina a lei complementar n. 87/96 e a lei ordinária n. 6374/89.

Considerando que realizar esses levantamentos não é tarefa simples e considerando a diversidade absurda de produtos nesta empreita, a administração resolveu "cortar caminho" e por este artigo no RICMS, criou uma nova regra, não disciplinada pela Lei complementar $\boldsymbol{n}$. 87/96, para apuração da base de cálculo, com base no Índice de Valor Adicionado Setorial IVA-ST, calculado com base nas informações prestadas pelos contribuintes.

Esse dispositivo é um exemplo cabal do mau uso da praticabilidade, representativo da execução simplificada no sentido vertical ${ }^{109}$, quando os regulamentos do executivo ou outras normas administrativas internas estabelecem abstrações generalizantes, com o objetivo de

109 DeRZI, Misabel de Abreu Machado. Direito tributário, direito penal e tipo, 2. ed. São Paulo: Revista dos Tribunais, 2008, p. 320. 
possibilitar a execução de norma hierarquicamente superior, sem previsão da lei formal para tanto, e que nosso sentir está eivado de vícios incorrendo em flagrantes inconstitucionalidades.

Inicialmente dispôs sobre base de cálculo da substituição tributária, cuja matéria é reservada à lei complementar, conforme dispõe o art. 155, § $2^{\circ}$., XII, "b" da Constituição Federal de 1988.

A lei complementar n. 87/96 exige que os critérios para fixação da margem de valor agregado sejam por lei (art. $8^{\circ}$., $4^{\circ}$.) e não por intermédio de um ato administrativo ou decreto.

Ao utilizar um percentual tabelado, sem considerar a média ponderada dos preços efetivamente praticados, afasta-se a base de cálculo presumida dos preços usualmente praticados no mercado, violando-se novamente a referida lei complementar e a lei ordinária n. $6374 / 89$.

A autoridade administrativa não colocou à disposição do contribuinte todos os elementos que comprovem que esse valor de IVA-ST corresponderá efetivamente à margem de valor agregado dos preços usualmente praticados no mercado.

Em síntese, essa medida simplificadora vertical na aplicação da substituição tributária rompe com os princípios da legalidade, igualdade, publicidade e devido processo legal, mostrando-se incompatível com os valores fundamentais protegidos em nossa Constituição.

Todavia não queremos dizer que tal desacerto invalida o instituto da substituição tributária.

Estamos convictos de que a substituição tributária é uma ferramenta valiosa e pode ser considerada constitucional desde que aplicada de forma proporcional e razoável, sem violação dos princípios da capacidade contributiva e da proibição de confisco, de forma a garantir um controle sobre o grau de ingerência do Estado na vida dos contribuintes.

Se o Supremo Tribunal Federal julgou pela constitucionalidade da substituição tributária de forma abstrata, não significa que os Estados e Distrito Federal podem utilizá-la de forma irrazoável, principalmente na fixação das bases de cálculo presumidas.

Quando isto ocorrer, cabe aos contribuintes e suas entidades representativas de classes discutir a tributação excessiva tanto administrativamente como judicialmente.

Aliás, neste sentido manifestou-se o Ministro Nelson Jobim em seu voto na ADI n. 2.777-8/SP, que assim delimitou o tema ${ }^{110}$ :

É importante identificar dois problemas:

${ }^{110}$ STF. Ação Direta de Inconstitucionalidade - ADI n. 2.777-8/SP. Min. Rel. César Peluso. 
(i) uma questão é o instrumento da ST;

(ii) outra questão é a forma como o Estado fixa os preços presumidos.

É importante notar que se o problema alegado é a disparidade entre o preço presumido e o preço efetivamente praticado, a utilização em si do instrumento da ST, e sua constitucionalidade ficam preservadas.

$[\ldots]$

O problema do eventual abuso do Estado na fixação do preço presumido se resolve por meio do procedimento administrativo-fiscal específico ou por meio de ação judicial específica com esse propósito, inclusive com liminares.

Concluímos, juntamente com o Ministro Nelson Jobim, que a substituição tributária como mecanismo a serviço da praticabilidade é imprescindível e tem sua constitucionalidade preservada ao se coadunar com as balizas constitucionais, desde que seja aplicada concretamente de forma razoável e proporcional. 


\title{
6.6 Simples Nacional
}

Há quase trinta anos a legislação vem oferecendo proteção às Microempresas e Empresas de Pequeno Porte. Em 1984 a Lei nº 7.256 introduziu o instituto da Microempresa em nosso ordenamento positivo e no mesmo ano, com a publicação do Decreto $\mathrm{n}^{\circ}$. 90.414, disciplinaram-se a criação e o funcionamento do Conselho de Desenvolvimento de Micro, Pequenas e Médias Empresas.

Com o advento da Constituição de 1988, procurou o constituinte dar um tratamento diferenciado às microempresas e empresas de pequeno porte.

Tal provimento manifestou-se expressamente como princípio da Ordem Econômica e Financeira de nossa Carta Magna, no seguinte dispositivo:

\begin{abstract}
Art. 170. A ordem econômica, fundada na valorização do trabalho humano e na livre iniciativa, tem por fim assegurar a todos existência digna, conforme os ditames da justiça social, observados os seguintes princípios:

$[\ldots]$

IX - tratamento favorecido para as empresas de pequeno porte constituídas sob as leis brasileiras e que tenham sua sede e administração no País.
\end{abstract}

A relevância do tema, levou o constituinte a retomá-lo no art. 179:

Art. 179. A União, os Estados, o Distrito Federal e os Municípios dispensarão às microempresas e às empresas de pequeno porte, assim definidas em lei, tratamento jurídico diferenciado, visando a incentivá-las pela simplificação de suas obrigações administrativas, tributárias, previdenciárias e creditícias, ou pela eliminação ou redução destas por meio de lei.

Assim, com base nestas normas constitucionais, foi criada a Lei $\mathrm{n}^{\circ} 9.317$, de 5 de dezembro de 1996"11, que instituía o Sistema Integrado de Pagamento de Imposto e Contribuições das Microempresas e das Empresas de Pequeno Porte- SIMPLES.

Esta lei dispunha que os tributos estaduais e municipais poderiam ser pagos no sistema simplificado, desde que os Estados e Municípios firmassem convênio com o sistema e produzissem as respectivas leis autorizando a diferente forma de recolhimento. ${ }^{112}$

\footnotetext{
${ }^{111}$ Lei n. 9317/96. Art. $1^{\circ}$ Esta Lei regula, em conformidade com o disposto no art. 179 da Constituição, o tratamento diferenciado, simplificado e favorecido, aplicável às microempresas e empresas de pequeno porte, relativo aos impostos e às contribuições que menciona.

112 DIAS, Caroline Said. Considerações sobre o Simples: Sistema Integrado de Pagamento de Impostos e Contribuições das Microempresas e Empresas de Pequeno Porte, Revista Dialética de Direito Tributário, n.54. São Paulo: Dialética, 2000, p. 20.
} 
O Estado de São de Paulo e muitos outros não firmaram esse "convênio" e acabaram por instituir regimes próprios de incentivo ao micro e pequeno empresário, como por exemplo: o Simples Paulista. Isto acabou por ocasionar uma verdadeira confusão de regimes, sendo que um determinado contribuinte poderia estar no âmbito do Simples Nacional e não estar incluído no Simples Paulista, ou vice-versa.

Esta situação permaneceu até que, com supedâneo na Emenda Complementar n. 42/2003, alterou-se o art. 146 da CF/88, incluindo-se a alínea "d" no inciso III e o Parágrafo Único:

Art. 146. Cabe à lei complementar:

[...] estabelecer normas gerais em matéria de legislação tributária, especialmente sobre:

d) definição de tratamento diferenciado e favorecido para as microempresas e para as empresas de pequeno porte, inclusive regimes especiais ou simplificados no caso do imposto previsto no art. 155, II, das contribuições previstas no art. 195, I e $\S \S 12 \mathrm{e}$ 13, e da contribuição a que se refere o art. 239.

Parágrafo único. A lei complementar de que trata o inciso III, d, também poderá instituir um regime único de arrecadação dos impostos e contribuições da União, dos Estados, do Distrito Federal e dos Municípios, observado que:

I - será opcional para o contribuinte;

II - poderão ser estabelecidas condições de enquadramento diferenciadas por Estado;

III - o recolhimento será unificado e centralizado e a distribuição da parcela de recursos pertencentes aos respectivos entes federados será imediata, vedada qualquer retenção ou condicionamento;

IV - a arrecadação, a fiscalização e a cobrança poderão ser compartilhadas pelos entes federados, adotado cadastro nacional único de contribuintes.

Por esta Emenda foi incluído o art. $94^{113}$ no Ato das Disposições Constitucionais Transitórias - ADCT, obrigando a todas as pessoas de direito público revogar seus regimes de tributação favorecida a micro e pequenas empresas. Tal imposição teve seu preço como veremos adiante.

Contemplando a previsão constitucional foi instituída a lei complementar n. 123 de 14 de dezembro de $2006^{114}$, que instituiu o Estatuto Nacional da Microempresa e da Empresa de Pequeno Porte, chamado de Simples Nacional, que pode ser definido como:

\footnotetext{
${ }^{113}$ CF/88- ADCT. Art. 94. Os regimes especiais de tributação para microempresas e empresas de pequeno porte próprios da União, dos Estados, do Distrito Federal e dos Municípios cessarão a partir da entrada em vigor do regime previsto no art. 146, III, d, da Constituição.

${ }^{114}$ Com alterações das Leis Complementares nos 127 , de 14 de agosto de 2007; n. 128, de 19 de dezembro de 2008; n. 133 de 28 de dezembro de 2009; e n. 139 de 2011.
} 
Regime especial de tributação por estimação objetiva, constituído em microssistema tributário, material, formal e processual, que unifica a fiscalização, o lançamento e a arrecadação de determinados impostos e contribuições de competência da União, Estados, Municípios e Distrito Federal, aplicável opcionalmente às Microempresas e Empresas de Pequeno Porte, com o escopo de atribuir a estes contribuintes tratamento fiscal diferenciado e favorecido, caráter parcialmente substitutivo ao regime geral e compulsório. ${ }^{115}$

Em síntese, o regime do Simples Nacional ou Supersimples é uma forma de pagamento mensal unificado de oito tributos: (i) Imposto de Renda das Pessoas Jurídicas - IRPJ; (ii) Contribuição Social sobre o Lucro Líquido - CSLL; (iii) Contribuição para os Programas de Integração Social-PIS/PASEP; (iv) Contribuição para Financiamento da Seguridade Social - COFINS; (v) Imposto sobre Produtos Industrializados - IPI; (vi) Contribuição Patronal Previdenciária - CPP; (vii) ICMS; e (viii) ISS.

Além de a facilitação no pagamento destes tributos, utilizando-se de uma única guia de recolhimento mensal, neste regime proporcionam-se várias simplificações nas obrigações acessórias, bem como vários outros benefícios.

Cada um desses oito tributos corresponde à aplicação de uma alíquota determinada em razão da atividade (indústria, comércio ou serviços) e da sua receita bruta nos últimos doze meses, sobre a receita bruta mensal auferida pelo contribuinte.

O Simples Nacional constitui-se em um plexo de normas construídas com base em ficções e presunções, a começar do critério material da hipótese de incidência "auferir receita bruta" e da base de cálculo "o valor da receita bruta auferida", utilizados em conjunto com cinco tabelas previstas no anexo da Lei complementar n. 123/06, que formarão as normas de incidência tributária de oito tributos distintos. ${ }^{116}$

Estas normas do Simples Nacional, ainda que tenham como foco principal simplificar o pagamento e reduzir as obrigações acessórias, são também normas a serviço da praticabilidade, que atuam como normas simplificadoras das lei instituidoras de vários tributos, permitindo sua aplicação a milhares de casos individuais.

\footnotetext{
${ }^{115}$ MARINS, James; BERTOLDI, Marcelo M. Simples Nacional - Estatuto da Microempresa e da Empresa de Pequeno Porte comentado. São Paulo: Revista dos Tribunais, 2007, p. 68.

116 “A adoção de estimação objetiva é técnica de política fisscal que preconiza a medição imediata do fator eleito pela lei como apto para revelar determinadas realidades econômicas ou financeiras ao Fisco mesmo que esta realidade seja distinta da materialidade do tributo que se pretende apurar. A Lei do Simples, ao eleger a receita bruta como base de cálculo para pagamento de tributos com bases de cálculo completamente distintas, consagrou o sistema da estimação objetiva”. MARINS, James; BERTOLDI, Marcelo M. Simples Nacional - Estatuto da Microempresa e da Empresa de Pequeno Porte comentado. São Paulo: RT, 2007, p. 69.
} 
O regime de tratamento favorecido para as empresas de pequeno porte está intimamente relacionado com os princípios da igualdade e da livre concorrência, conforme doutrina Luís Eduardo Schoueri ${ }^{117}$ :

Relaciona-se o Princípio do Tratamento Favorecido para as Empresas de Pequeno Porte com o próprio Princípio da Livre Concorrência, cuja concretização, o mercado, depende da existência de razoavelmente elevado número de participantes. Sendo a Livre-Iniciativa, juntamente com a Valorização do Trabalho, fundamento da Ordem Econômica, ambas encontram na multiplicação de empresas de pequeno porte terreno fértil. Trata, ainda, o Princípio, da própria ideia de igualdade vertical, que implica um tratamento diferenciado para aqueles que se encontram em situação diversa.

As críticas ao regime o Simples Nacional não são poucas!

Com base no entendimento que este regime fere o princípio da legalidade, alguns juristas defendem que a única forma de preservar sua existência jurídica é atribuir à natureza do Simples uma nova espécie tributária. ${ }^{118}$

A afronta ao princípio federativo em razão da vinculação obrigatória dos Estadosmembros, Distrito Federal e Munícipios ao Simples Nacional é outro ponto polêmico apontado por parte da doutrina que questiona sua constitucionalidade. ${ }^{119}$

Outra crítica bastante frequente ${ }^{120}$ é sobre a complexidade normativa do Simples. Por abranger diferentes formas de tributação (indústria, comércio e vários tipos de serviços), com inúmeras exceções (exportações, diferimento, isenções etc.) aplicadas a oito tributos distintos, com alíquotas distribuídas em cinco tabelas distintas, é grande a quantidade de normas do regime, implicando em enormes dificuldades na sua utilização.

\footnotetext{
${ }^{117}$ SCHOUERI, Luís Eduardo. Direito Tributário. São Paulo: Saraiva, 2011, p. 348.

118 “[...] há incompatibilidade visível com o preceito constitucional da estrita legalidade, só podendo ser afastada, se admitirmos, que em verdade, o Simples não seria mera cobrança unificada e simplificada de outros tributos, mas sim uma nova espécie tributária.

$[\ldots]$

Deste modo, a única tese capaz de salvaguardar a cobrança do Simples é entender que a nova forma de tributação consistiria em nova espécie tributária, como novo fato gerador, novos contribuintes e novas alíquotas, ou seja, que os microempresários e empresários de pequeno porte estariam isentos do pagamento dos tributos englobados pelo Simples, tendo somente a nova obrigação tributária, que seria o Simples". DIAS, Caroline Said. Considerações sobre o Simples: Sistema Integrado de Pagamento de Impostos e Contribuições das Microempresas e Empresas de Pequeno Porte, Revista Dialética de Direito Tributário, n.54. São Paulo: Dialética, 2000, p. 23.

119 Robinson Barreirinhas afirma ser inconstitucional a Emenda n. 42/2003 por ferir o pacto federativo ao retirar as competências dos Estados, Distrito Federal e Municípios, agredindo suas autonomias financeiras. Segundo ele, "emenda constitucional tendente a abolir a forma federativa é qualquer emenda que fira algum dos elementos característicos da Federação Brasileira. Não é necessário que tal emenda fira de morte a Federação, basta que tal medida legislativa prejudique o pacto federativo, mesmo que, simplesmente, reduzindo o alcance de algum de seus princípios norteadores". BARREIRINHAS, Robinson Sakiyama. Inconstitucionalidade do "Super Simples". Revista Dialética de Direito Tributário, n.126. São Paulo: Dialética, 2006, p.45.

${ }^{120}$ Omar Augusto Melo afirma que: "Quanto ao aspecto tributário, esta lei complementar apenas reforça que no manicômio tributário brasileiro até mesmo o SUPER SIMPLES é complicado". MANGIERI, Francisco Ramos; MELO, Omar Augusto Leite. Super Simples - Anotado e Comparado. São Paulo: Edipro, 2007, p. 13.
} 
O Simples, por essa razão, não tem nada de simples, e chegam alguns autores ${ }^{121}$ a apontar que a redução na carga tributária que este regime traz é simples falácia.

Uma regra que chama bastante a atenção e praticamente passa desapercebida pelos críticos do regime, trata-se da substituição tributária aplicada nos contribuintes do Simples Nacional.

Por força da Resolução n. 61 do Comitê Gestor do Simples Nacional (CGSN), o valor de ICMS a pagar pelo contribuinte do SIMPLES substituído corresponde ao valor resultante da aplicação da alíquota interna ou interestadual sobre o valor da operação ou prestação própria do substituto tributário, ou seja, o SIMPLES passa a ser tributado como se fosse um contribuinte que não está abrangido pelo regime diferenciado!

Para visualizarmos o problema, vamos inicialmente imaginar uma empresa que comercializa um produto que não esteja na modalidade da substituição tributária. Se o valor agregado na venda deste produto for, por hipótese, $\mathrm{R} \$ 100,00$, o valor de ICMS que este contribuinte iria pagar nesta venda poderá oscilar entre os valores de $\mathrm{R} \$ 1,25$ e $\mathrm{R} \$ 3,95$, dependendo de sua receita bruta anual.

Agora, se este produto estiver na modalidade de substituição tributária, aqui no Estado de São Paulo, por força do art. 268 do RICMS ${ }^{122}$, o valor de ICMS a ser pago será de R\$ 18,00 !

Como praticamente a totalidade dos segmentos econômicos da economia paulista está instituída na modalidade de substituição tributária, esta regra neutraliza totalmente os efeitos do Simples Nacional, com a majoração da carga tributária para os optantes do regime.

O valor do ICMS do contribuinte do SIMPLES é calculado no encerramento do mês, a partir de sua receita bruta naquele mês multiplicada pela alíquota encontrada em razão de sua atividade e da receita bruta dos últimos doze meses. Como calcular esse valor no momento da venda do substituto antes do encerramento do mês? Como a alíquota pode mudar a cada mês, qual alíquota utilizar?

\footnotetext{
${ }^{121}$ LEITE, Harrison Ferreira. Simples: redução da carga tributária ou falácia? Revista Tributária e de Finanças Públicas, $\mathrm{n}$. 63. São Paulo: Revista dos Tribunais, 2005.

${ }^{122}$ RICMS. Decreto 45.590/00. Artigo 268 - O valor do imposto a ser recolhido a título de sujeição passiva por substituição é a diferença entre o valor do imposto calculado mediante aplicação da alíquota interna sobre a base de cálculo prevista para a operação ou prestação sujeita à substituição tributária e o valor do imposto devido pela operação ou prestação própria do remetente

[...]

$\S 2^{\circ}$ - Na hipótese de o sujeito passivo por substituição tributária estar sujeito às normas do Regime Especial Unificado de Arrecadação de Tributos e Contribuições devidos pelas Microempresas e Empresas de Pequeno Porte - "Simples Nacional": 1 - o valor do imposto a ser recolhido a título de sujeição passiva por substituição é a diferença entre o valor do imposto calculado mediante a aplicação da alíquota interna sobre a base de cálculo prevista para a operação ou prestação sujeita à substituição tributária e o valor resultante da aplicação da alíquota interna ou interestadual, conforme o caso, sobre o valor da operação ou prestação própria do remetente; [...].
} 
Como se percebe, a razão para esta regra é a impossibilidade de calcular o valor do ICMS no momento da venda por parte do substituto.

Mas será que equipar o SIMPLES ao regime normal de apuração, aumentando significativamente sua carga tributária, é a solução mais compatível com os balizamentos constitucionais? Adotar essa medida em nome da praticabilidade será a solução?

Pensamos que não. Ainda que o SIMPLES Nacional seja um regime sujeito a críticas e aperfeiçoamentos, ele atende o dever de observância à determinação constitucional de prover tratamento favorecido às pequenas empresas, expressamente previsto no arts. 170, IX e 179 da CF/88.

O regime diferenciado visa atender também ao sobreprincípio da igualdade material, tratando igualmente os iguais e desigualmente os desiguais, na medida de sua desigualdade.

Qualquer tipo de medida simplificadora que rompe com a ideia de igualdade não se compatibiliza com a praticabilidade que visa garantir a aplicabilidade da lei, mas sempre na busca de uma maior justiça fiscal! 


\section{Conclusões}

1) A realidade que o nosso direito tributário assiste, em razão da sociedade hipercomplexa em que vivemos, é composta por: um número muito elevado e crescente de contribuintes em uma multiplicidade de relações sociais que fazem surgir a cada instante novos fatos econômicos não previstos em nosso ordenamento; uma legislação extremamente complexa e de difícil aplicação; uma administração com dificuldades crescentes para o gerenciamento e fiscalização dos tributos; e um Estado cada vez mais carente de recursos para o cumprimento de sua função social.

2) A complexidade da legislação é fruto da obsolescência das leis em face às mutações sociais e econômicas e da ânsia do legislador de querer medir a efetiva capacidade econômica individual.

3) A incapacidade administrativa ocorre em razão da falta de pessoal e recursos materiais para a averiguação de cada caso individualmente considerado na aplicação e fiscalização dos tributos.

4) No Estado Democrático de Direito a tributação não se constitui em um fim em si mesmo, mas instrumento para o cumprimento de sua função social e realização de justiça, razão pela qual o Estado deve sempre prezar por um sistema fiscal eficiente e ágil capaz de arrecadar, com o menor dispêndio possível, os recursos necessários para atingir seus objetivos.

5) A eficiência administrativa na tributação não justifica que as pessoas jurídicas de direito público ultrapassem os limites de sua competência, tributando fatos signos de riqueza não previstos nos arquétipos constitucionais, ou que já se encontrem nas hipóteses de incidência de tributos de competência de outros entes federativos. Além disso, a eficiência é uma meta a ser perseguida sempre nos limites dos princípios da segurança jurídica, isonomia e da capacidade contributiva, sob pena de uma discricionariedade tal que conduza ao arbítrio.

6) Em razão de todas essas demandas surge a praticabilidade designando a totalidade das condições que garantem um execução eficiente e econômica das leis, ou seja, torna o direito exequível.

7) A utilização das normas simplificadoras, observando-se o primado da praticabilidade, possibilita a aplicação das leis em massa de forma célere e menos onerosa, desonerando a administração, na busca da verdadeira manifestação de capacidade econômica, da difícil missão de apurar todo o potencial de diferenciação e individualização. 
8) As normas simplificadoras, ainda que não tenham a função precípua de melhorar a arrecadação, tratam da tributação e estão, portanto, sujeitas a princípios e normas gerais do sistema jurídico tributário, mas seu caráter extrafiscal torna-se relevante ao permitir ponderações de proporcionalidade e razoabilidade com outros valores protegidos pelos demais princípios constitucionais, implicando num novo balanço de forças que resultará na realização da justiça no caso concreto.

9) A indeterminabilidade é uma técnica que possibilita ao legislador maior amplitude na abrangência de situações da realidade social. Sua utilização, porém, irá demandar na aplicação das normas tributárias de técnicas de fechamento, por intermédio de padrões e esquemas generalizantes implementados pelo uso das presunções e ficções.

10) Com as padronizações, obtidas pelas presunções e ficções, prescinde-se de atingir a realidade social em toda sua complexidade, facilitando a prova do fato social e consequentemente da ocorrência do fato jurídico tributário. As presunções e ficções apresentam-se como instrumentos legais a serviço da praticabilidade ao possibilitar a aplicação de uma norma tributária a milhares de casos e por facilitar a mensuração da riqueza tributável sem a busca exaustiva da capacidade contributiva de cada caso individualmente considerado.

11) A natureza jurídica das presunções será sempre considerada normativa, seja através de norma geral e abstrata nas presunções legais, seja através de norma individual e concreta nas presunções hominis.

12) A presunção relativa nem sempre é norma jurídica de direito adjetivo ou formal. Quando for admitida a produção de prova em contrário em momento posterior à constituição do débito tributário com base em fato tributário presumido, estaremos diante de norma jurídica de direito adjetivo ou formal; caso contrário, estaremos tratando de norma de direito material ou substantivo.

13) Não consideramos as presunções absolutas e as ficções como verdades absolutas e que não admitem prova em contrário. Tratam-se de regras remissivas de direito substantivo, ampliando o âmbito de aplicação de uma norma jurídica a novos casos. O que as distingue é que nas presunções absolutas a remissão está baseada numa relação empírica entre os fatos e nas ficções em outras razões consideradas importantes pelo legislador para equiparar os regimes jurídicos preexistentes.

14) As presunções absolutas e ficções exercem um importante papel no desenvolvimento e aceitação das mudanças jurídicas, ao evitar a quebra abrupta de continuidade do sistema e por possibilitar enquadrar as novas disposições em formas preexistentes. 
15) As presunções relativas e as simples prestam-se melhor no combate à sonegação, quando as provas são propositadamente obstaculizadas pelo contribuinte, ou ainda, como sanção pelo descumprimento dos deveres instrumentais por parte do contribuinte.

16) A utilização de presunções absolutas e ficções não devem ser afastadas peremptoriamente do nosso sistema tributário. Enquanto não se admite o recurso às ficções e presunções absolutas na equiparação de outros fatos econômicos àqueles fatos jurídicos (signos presuntivos de riqueza) eleitos pelo constituinte como aspectos materiais da hipótese de incidência tributária, sob pena de menosprezo aos princípios constitucionais da rígida discriminação de competência, tipicidade e capacidade contributiva, é possível, em atendimento à praticabilidade alterar os critérios pessoal, espacial, temporal e, principalmente, o aspecto quantitativo da base de cálculo, padronizando a mensuração da riqueza tributável, sem que com isso, na maioria das vezes, esteja contrariando valores constitucionalmente fixados.

17) A padronização ou tipificação é a técnica de alteração do aspecto quantitativo, em particular a base de cálculo, pelas presunções e ficções. A presunção, em nome da praticabilidade, de uma base de cálculo fixada na normalidade média, abstraindo-se os casos atípicos ou anormais, é imprescindível na tributação em massa, garantindo uma arrecadação eficiente, um imposto exequível e praticável, além de um sistema fiscal coerente.

18) Não há como negar o caráter principiológico da praticabilidade. Trata-se de verdadeiro princípio implícito construído nas dobras do princípio da legalidade ao garantir que as leis sejam viáveis, exequíveis e executáveis, delimitando o âmbito de atuação do legislador infraconstitucional, bem como a interpretação e aplicação das normas tributárias. A resolução dos conflitos, que certamente surgirão da praticidade com os outros princípios constitucionais, deverá ocorrer pela análise e sopesamento do peso relativo de cada um, em cada caso concreto, juntamente com o cotejo das regras que definem e delimitam de forma mais precisa o mecanismo de realização e escopo de abrangência desses princípios.

19) Não há conflito entre a praticabilidade e o princípio da segurança jurídica, pois a utilização de bases presuntivas nas situações em que a medição efetiva da riqueza representa uma enorme dificuldade prática, traz certeza e previsibilidade diminuindo a pressão fiscal indireta sobre o contribuinte.

20) O primado da praticabilidade não ofende e muito menos ignora o princípio da legalidade, valor supremo em nossa Constituição, mas nele operam atenuações ao reduzir o excesso de pormenorizações que a tipicidade cerrada exige e que conduziriam, em razão das dificuldades crônicas da administração, a situações de manifesta iniquidade. A praticabilidade 
em consonância com o princípio da legalidade converte a tributação individual em tributação pela média, transformando a legalidade do caso concreto em legalidade do caso padrão.

21) As padronizações, resultado do sopesamento entre a capacidade contributiva e a praticabilidade, representam verdadeiros instrumentos jurídicos hábeis a contemplar o princípio da igualdade no direito tributário, quando permitem realizar a tributação generalizada da riqueza. Com elas, o legislador não busca a igualdade individual, mas sim a igualdade geral, de forma a conseguir tributar de forma isonômica um número muito maior de contribuintes, do que conseguiria se fosse levada em conta a verificação individual da capacidade contributiva.

22) A praticabilidade além de compatível com a justiça fiscal, é um dos principais meios de sua realização, tanto pela possibilidade de aplicação e execução da lei tributária aos milhares de contribuintes de forma isonômica, quanto pelo fato de somente a lei clara e simples ter aptidão para conduzir à afirmação da segurança jurídica e promover a justiça tributária.

23) As simplificações tributárias, traduzidas nas padronizações pelo uso de presunções e ficções, mormente da base de cálculo, não poderão desvinculá-la a ponto de não mais representar uma medida da materialidade da hipótese de incidência, sob pena de, assim o fazendo, serem consideradas inconstitucionais, por invasão de competências, pondo em risco o pacto federativo.

24) No implemento das padronizações como medidas para realização do fim específico da praticabilidade, portanto com caráter extrafiscal, caberá examinar se a medida do distanciamento da igualdade é proporcional (exame de proporcionalidade) e, para tanto, realizar exame da necessidade, adequação e proporcionalidade em sentido estrito; caso contrário, a realização da igualdade estará comprometida.

25) O caráter voluntário e opcional destes regimes colaboram para a vinculação com a realidade em momento anterior à padronização, além de permitir corrigir eventuais distorções, que em alguns casos singulares poderão ocorrer, colaborando sobremaneira para a certeza e previsibilidade, aspectos cruciais para a segurança jurídica nas relações tributárias.

26) A neutralidade representa uma limitação para a atuação do legislador tributário na instituição de padronizações, que não poderão alterar a situação de livre concorrência entre contribuintes que se encontram em igualdade de oportunidade em determinado setor do mercado.

27) A ponderação do princípio da praticabilidade com os demais princípios constitucionais permite visualizar os seguintes limites à sua utilização: (i) obediência à repartição constitucional de competências; (ii) seja demonstrada a necessidade da medida, em razão da deficiência administrativa, ou seja, a supressão da simplificação implicaria um 
aumento desproporcionado dos custos de gestão, repercutindo-se em prejuízo de todos; (iii) que o valor padrão reflita verdadeiramente a média, ou a normalidade das situações fáticas, aproximando o máximo possível da real capacidade econômica dos contribuintes; (iv) que a padronização seja justificada por manter uma relação de razoabilidade com a média dos casos alcançados pela tributação; (v) sejam previstas cláusulas de equidade, que possibilitem a correção das distorções entre o valor padrão e o valor real, com a respectiva devolução do tributo pago a maior; (vi) o regime simplificado deverá ser opcional facultando aos contribuintes sujeitar-se ou não a tais regimes, segundo aquilo que entender mais proveitoso; e (viii) respeito aos direitos e princípios constitucionais, buscando-se sempre a convivência harmônica entre estes princípios e a praticabilidade, de forma a que seja alcançada a almejada justiça fiscal.

28) A Planta Genérica de Valores é uma norma simplificadora a serviço da praticabilidade, que supre a impossibilidade prática da avaliação individual do valor venal de cada imóvel, facilitando e racionalizando o lançamento do IPTU. Com ela resguarda-se a necessária uniformidade no comportamento do Fisco, evitam-se discrepâncias próprias do arbítrio e representa-se segurança para o Fisco e os contribuintes.

29) A utilização das pautas fiscais pelo fisco, ainda que represente um mecanismo de simplificação ao físco no controle da sonegação e evasão fiscal, não está a serviço da praticabilidade, como forma de permitir aplicar o tributo à maioria dos contribuintes e com isso atingir muito mais igualdade em um sistema deficiente de verificação individual de capacidade econômica. Ao representarem uma agressão à legalidade e à capacidade contributiva, sua utilização deve ser repelida como forma de garantia contra o arbítrio e insegurança jurídica.

30) A tabela de valores de veículos usados, utilizada no IPVA, padroniza a base de cálculo com a média dos valores de mercado dos veículos de mesmo modelo e ano, desprezando-se o estado de conservação e outros itens menores de diferenciação, que tornam possível a exequibilidade da norma, garantem a receita indispensável ao Estado para consecução de suas finalidades, sem ofensa maior à capacidade contributiva individual.

31) A apuração opcional pelo lucro presumido apresenta-se como um excelente instrumento de simplificação, atendendo ao mandamento da praticabilidade, sem deixar de manter uma relação de razoabilidade com a média efetiva dos lucros apurados na classe de contribuintes contemplados.

32) A substituição tributária para frente é um mecanismo eficiente a serviço da praticabilidade, que torna mais viável e menos onerosa a aplicação e fiscalização do ICMS à administração pública, sem deixar de atender à maior garantia do crédito e controle da 
sonegação, reduzindo a alguns poucos contribuintes substitutos a obrigação pelo recolhimento antecipado do tributo de fatos presumidos a serem praticados por milhares de outros contribuintes substituídos.

33) O problema da substituição tributária está na sua utilização de forma irrazoável pelos entes federativos, que desconsideram a média ponderada dos preços efetivamente praticados no mercado e aplicam margens fixas de valor agregado, utilizando-se de decretos ou portarias, rompendo com os princípios da legalidade, igualdade, publicidade e devido processo legal.

34) O regime do Simples Nacional, ainda que tenha como foco principal simplificar o pagamento e reduzir as obrigações acessórias, atendendo o dever de observância à determinação constitucional de prover tratamento diferenciado às pequenas empresas, são também normas a serviço da praticabilidade, que atuam como normas simplificadoras das lei instituidoras de vários tributos e permitem sua aplicação a milhares de casos individuais.

35) A praticabilidade é um princípio que surgiu da necessidade do direito poder acompanhar nossa realidade em constante transformação, permitindo a ponderação da capacidade contributiva e legalidade com a aplicação eficiente e econômica em massa das leis tributárias, de forma a garantir a arrecadação dos recursos necessários para o atingimento do bem comum. Ainda que torne o direito praticável, seu uso não é ilimitado. A praticabilidade não pode ser uma panaceia para os crônicos problemas da administração pública, que sob o manto da facilidade, simplicidade e eficiência na arrecadação, acaba por vezes desvirtuando sua finalidade pela utilização irrazoável, abandonando os compromissos do Estado Democrático de Direito. 


\section{Referências Bibliográficas}

ABDENUR, Roberto. A boa notícia, um alerta e os impostos. Disponível em: <http://www.estadao.com.br/noticias/impresso,a-boa-noticia-um-alerta-e-os-impostos,904062,0.htm>. Acesso em: 23 julho 2012.

ADEODATO, João Maurício. Ética e Retórica - para uma Teoria da Dogmática Jurídica. São Paulo: Saraiva, 2002.

ALEXY, Robert. Colisão de direitos fundamentais e realização de direitos fundamentais no Estado de Direito Democrático. Revista de Direito Administrativo, v. 217. Rio de Janeiro: Renovar, 1999.

AMARO, Luciano. Direito Tributário Brasileiro. $15^{\text {a }}$. edição. São Paulo: Saraiva, 2009

ANDRADE, José Maria Arruda de. Interpretação da Norma Tributária. São Paulo: MP: APET, 2006.

ATALIBA, Geraldo. Hipótese de Incidência Tributária. 6 ${ }^{\mathrm{a}}$. edição. São Paulo: Malheiros, 2005.

. República e Constituição. 2a . edição. São Paulo: Malheiros, 2004.

. Lei complementar em Matéria Tributária. Revista de Direito Tributário, v.13, n.48. São Paulo: Revista dos Tribunais, 1990. . Interpretação no Direito Tributário. São Paulo: EDUC/Saraiva, 1975. . ICMS na Constituição. Revista de Direito Tributário. v.15. n.57. São

Paulo: Revista dos Tribunais, 1991.

. e GIARDINO, Cléber. Revista de Direito Tributário, n.34. São Paulo:

Revista dos Tribunais, 1985. . Imposto predial e taxas de serviços urbanos. Revista de Direito Público. n. 11. São Paulo: Revista do Tribunais, jan./mar. 1979. 
ÁVILA, Humberto Bergmann. Teoria dos Princípios - Da Definição à Aplicação dos Princípios Jurídicos. 4ª edição. São Paulo: Malheiros, 2004.

A distinção entre princípios e regras e a redefinição do dever de proporcionalidade. Revista de Direito Administrativo, Rio de Janeiro: Renovar, vol. 215, 1999. . A Teoria dos Princípios e o Direito Tributário. Revista Dialética de Direito Tributário, n.125. São Paulo: Dialética, 2006.

Imposto sobre a circulação de mercadorias: ICMS; substituição tributária; base de cálculo; pauta fiscal; preço máximo ao consumidor; diferença constante entre o preço usualmente praticado e o preço constante da pauta ou o preço máximo ao consumidor sugerido pelo fabricante; exame de constitucionalidade. Revista Dialética de Direito Tributário, n.123. São Paulo: Dialética, 2005.

. Princípios e Regras e a Segurança Jurídica. In SANTI, Eurico Marcos Diniz de (coord.). II Congresso Nacional de Estudos Tributários do IBET-Segurança Jurídica na Tributação e Estado de Direito. São Paulo: Noeses, 2006.

. Proporcionalidade e Direito Tributário. Revista Direito Tributário Atual, n.25. São Paulo: Dialética, 2011.

- Repensando o princípio da supremacia do interesse público sobre o particular. Revista Trimestral de Direito Público, n.24. São Paulo: Revista dos Tribunais,1998. . Sistema constitucional tributário. $2^{\mathrm{a}}$ edição. São Paulo: Saraiva, 2006. . Substituição tributária e base de cálculo: os limites da padronização fiscal. Revista da Ajuris, v.32, n.100. Porto Alegre: Livraria do Advogado, 2005.

. Teoria da Igualdade Tributária. 2a . edição. São Paulo: Malheiros, 2009.

BALEEIRO, Aliomar. Direito Tributário Brasileiro. 11ª . edição. Rio de Janeiro: Forense, 2000.

BANDEIRA DE MELLO, Celso Antônio. Curso de Direito Administrativo. 20. edição. Sâo Paulo: Malheiros, 2006.

O Conteúdo Jurídico do Princípio da Igualdade. 3. ed. São Paulo: Malheiros, 2002.

BARBOSA, Ruy. Oração aos moços. São Paulo: Martin Claret, 2003. 
BARREIRINHAS, Robinson Sakiyama. Inconstitucionalidade do "Super Simples”. Revista Dialética de Direito Tributário, n.126. São Paulo: Dialética, 2006.

BARRETO, Aires Fernandino. Curso de Direito Tributário Municipal. São Paulo: Saraiva, 2009. ISS na Constituição e na Lei. $3^{\text {a }}$ edição. São Paulo: Dialética, 2009. ;BARRETO, Paulo Ayres. Imunidades Tributárias - Limitações Constitucionais ao Poder de Tributar. 2a . edição. São Paulo: Dialética, 2001.

; GIARDINO, Cléber. Presunções no Direito Tributário. In: Martins, Ives Gandra da Silva (Coord). Caderno de Pesquisas Tributárias: presunções no direito tributário. Vol. 9. São Paulo: Resenha Tributária, CEEU, 1984.

BARRETO, Paulo Ayres. Contribuições: regime jurídico, destinação e controle. São Paulo: Noeses, 2006.

A Tributação no Setor Industrial. In SANTI, Eurico Marcos Diniz (coord.). Curso de Direito Tributário e Finanças Públicas: do fato à norma, da realidade ao conceito jurídico. São Paulo: Saraiva, 2008. . Elisão Tributária - Limites Normativos. São Paulo: USP, 2008. . Imposto Sobre a Renda e a Lei complementar 104 de 2001. Revista de Direito Tributário, n. 85. São Paulo: Revista dos Tribunais, 2002. . Imposto Sobre a Renda e Preços de Transferência. São Paulo: Dialética, 2001.

BASTOS, Celso Ribeiro. Lei complementar - Teoria e Comentários. São Paulo: Saraiva, 1985.

BECKER, Alfredo Augusto. Teoria Geral do Direito Tributário. 5a. edição. São Paulo: Noeses, 2010.

BERLIRI, Luigi Vitorio. L'Imposta di Riccheza Mobile. Milão: A. Giuffrè, 1949.

BOBBIO, Norberto. Teoria da Norma Jurídica. São Paulo: Edipro, 2001. . Teoria do Ordenamento Jurídico. 10a . edição. Brasília: Universidade de Brasília, 1997a. 
BONILHA, Paulo Celso Bergstrom. Da Prova no Processo Administrativo Tributário. São Paulo: LTR, 1992.

BORGES, José Souto Maior. Tratado de Direito Tributário Brasileiro Lançamento Tributário. Vol. IV. Rio de Janeiro: Forense, 1981.

. Princípio constitucional da legalidade e as categorias obrigacionais. Revista de Direito Tributário, n. 23-24. São Paulo: Revista dos Tribunais, 1983. . Princípio da segurança jurídica na criação e aplicação do tributo. Revista de Direito Tributário, n. 63. São Paulo: Revista dos Tribunais, 1993.

CANOTILHO, J.J. GOMES. Direito Constitucional e Teoria da Constituição. $5^{\mathrm{a}}$. edição. Coimbra: Livraria Almedina, 1991.

CANTO, Gilberto Ulhoa. Presunções no Direito Tributário. In: Martins, Ives Gandra da Silva (Coord). Caderno de Pesquisas Tributárias: presunções no direito tributário. Vol. 9. São Paulo: Resenha Tributária, CEEU, 1984.

CARDOSO, Alessandro Mendes. A Responsabilidade do Substituto Tributário e os limites à Praticidade. Revista Tributária e de Finanças Públicas, n. 68. São Paulo: Revista dos Tribunais, 2006.

CARRAZZA, Roque Antonio. Curso de Direito Constitucional Tributário. 22a . edição. São Paulo: Malheiros, 2006.

CARVAlHO, Aurora Tomazini de. Curso de Teoria Geral do Direito: o constructivismo lógico-semântico. São Paulo: Noeses, 2009.

CARVAlHO, Cristiano Carvalho. Ficções jurídicas no Direito Tributário. São Paulo: Noeses, 2008.

CARVAlHO, Paulo de Barros. Direito Tributário, Linguagem e Método. $3^{\mathrm{a}}$. edição. São Paulo: Noeses, 2009.

A prova no procedimento administrativo tributário. Revista de Direito Tributário, n. 34. São Paulo: Revista dos Tribunais, 1998. 
.Apostila do curso de extensão em teoria geral do direito. São Paulo: IBET/SP, 2007.

. Curso de Direito Tributário. 17a . edição. São Paulo: Saraiva, 2005.

. Fundamentos Jurídicos da Incidência Tributária. $8^{\text {a }}$. edição. São Paulo:

Saraiva, 2010.

. ICMS. Revista de Direito Tributário, v. 48. São Paulo: Revista dos

Tribunais, 1989.

. Limitações ao poder de tributar. Revista de Direito Tributário, n. 46. São

Paulo: Revista dos Tribunais, 1988.

. O Preâmbulo e a Prescritividade Constitutiva dos Textos Jurídicos. Revista

Brasileira de Direito Tributário e Finanças Públicas, v. 11. São Paulo: LexMagister, 2009.

. O Princípio da Segurança Jurídica em matéria tributária. Revista de Direito

Tributário, n. 61. São Paulo: Malheiros 1992.

. Prefácio à obra de H. T. TôRRES. Direito Tributário e Direito Privado -

Autonomia Privada, Simulação, Elusão Tributária. São Paulo: RT, 2003.

- Sobre os Princípios Constitucionais Tributários. Revista de Direito

Tributário, , v. 55. São Paulo: Revista dos Tribunais, 1991.

. Teoria da Norma Tributária. 4ª edição. São Paulo: Max Limonad, 2002.

CHIESA, Clélio. A Competência Tributária do Estado Brasileiro. São Paulo: Max Limonad, 2002.

. ICMS. A Denominada Substituição Tributária "Para Frente". Revista dos Tribunais, São Paulo: Revista dos Tribunais, Ano 7, n. 29, p. 61, out.-dez. 1999. . ICMS -Sistema Constitucional Tributário. São Paulo: LTr, 1997.

COÊLHO, Sacha Calmon Navarro. Curso de Direito Tributário Brasileiro. $5^{\mathrm{a}}$. edição. Rio de Janeiro: Forense, 2000. . Comentários à Constituição de 1988 - Sistema Tributário. $3^{\text {a }}$. edição. Rio de Janeiro: Forense, 1991.

COMPARATO, Fábio Konder. O poder de controle na sociedade anônima. $3^{\mathrm{a}}$. edição. Rio de Janeiro: Forense, 1983. 
CONTI, Jose Maurício. Considerações sobre o Federalismo Fiscal Brasileiro em uma perspectiva comparada. In: CONTI, Jose Maurício (Org.); SCAFF, Fernando Facury (Org.); BRAGA, Carlos Eduardo Faraco (Org.). Federalismo Fiscal: Questões Contemporâneas. Florianópolis: Conceito Editorial, 2010. . Federalismo fiscal e fundos de participação. São Paulo: Juarez de Oliveira, 2001.

COSTA, Alcides Jorge. Capacidade Contributiva. Revista de Direito Tributário, $\mathrm{n}$. 55. São Paulo: Revista dos Tribunais, 1991.

COSTA, Regina Helena. Princípio da Capacidade Contributiva. $3^{\text {a }}$. edição. São Paulo: Malheiros, 2003.

. Conceitos Jurídicos indeterminados e discricionaridade administrativa. Revista de Direito Público, n. 95. São Paulo: Revista dos Tribunais, 1990.

. Curso de Direito Tributário. São Paulo: Saraiva, 2009. . Praticabilidade e Justiça Tributária. Exeqüibilidade de Lei Tributária e Direitos do Contribuinte. São Paulo: Malheiros, 2007.

DE MITA, Enrico. O Princípio da Capacidade Contributiva. In FERRAZ, Roberto (coord.). Princípios e Limites da Tributação. São Paulo: Quartier Latin, 2005.

DERZI, Misabel de Abreu Machado. Direito Tributário, Direito Penal e Tipo. 2a edição. São Paulo: Revista dos Tribunais, 2007.

. A Praticidade, a substituição tributária e o direito fundamental à justiça individual. In: FISCHER, Octavio Campos (Coord.). Tributos e Direitos Fundamentais. São Paulo: Dialética, 2004.

. Praticidade. ICMS. Substituição tributária progressiva, "para frente”. In: Construindo o Direito Tributário na Constituição: uma análise da obra do Ministro Carlos Mário Velloso. Belo Horizonte: Del Rey, 2004, p. 169-190.

. Distorções no Princípio da Não-Cumulatividade no ICMS- Comparação com o IVA EUROPEU. In: Temas de Direito Tributário. Belo Horizonte: Del Rey, 1998. . Legalidade material, modo de pensar 'tipificante’ e praticidade no direito tributário. Justiça Tributária- $1^{o}$. Congresso Internacional de Direito Tributário - IBET. São Paulo, Max Limonad, 1998. 
- Princípio da praticidade do direito tributario (seguranca juridica e tributacao). Revista de Direito Tributário, v.13. n.47. Sao Paulo: Revista dos Tribunais, 1989.

DI PIETRO, Maria Sylvia Zanella. Direito Administrativo. $15^{\mathrm{a}}$. ed. São Paulo: Atlas, 2003.

DIAS, Caroline Said. Considerações sobre o Simples: Sistema Integrado de Pagamento de Impostos e Contribuições das Microempresas e Empresas de Pequeno Porte. Revista Dialética de Direito Tributário, n. 54. São Paulo: Dialética, 2000.

DWORKIN, Ronald. Taking Rights Seriously. London: Duckwoth, 1991.

ENGISH, Karl. Introdução ao Pensamento Jurídico. trad. de João Baptista Machado. $7^{\text {a }}$ ed. Lisboa: Calouste Gulbenkian, 1996.

FERNANDES, Luis Dias. Repetição do Indébito Tributário. O inconstitucional Artigo 166 do CTN. Rio de Janeiro: Forense, 2002.

FERRAZ JR, Tércio Sampaio. Introdução ao Estudo do Direito - Técnica, Decisão, Dominação. 4a . edição. São Paulo: Atlas, 2003. . A Ciência do Direito. 2a . edição. São Paulo: Atlas, 1980.

. Conceito de Sistema no Direito Positivo. São Paulo: Revista dos Tribunais, 1976.

. Direito, Retórica e Comunicação. $2^{\text {a }}$. edição. São Paulo: Saraiva, 1997.

. Estudos de Filosofia do Direito. Reflexões sobre o Poder, a Liberdade, a Justiça e o Direito. 2a . edição. São Paulo: Atlas, 2003.

. Normas Gerais e Competência Concorrente - uma Exegese do art.24 da Constituição Federal. Revista Trimestral de Direito Público, 7. São Paulo: Malheiros, 1994.

- Segurança Jurídica e Normas Gerais Tributárias. Revista de Direito Tributário, n. 17/18, ano 5. São Paulo: Revista dos Tribunais , 1981.

. Teoria da Norma Jurídica - Ensaio de Pragmática da Comunicação

Normativa. Rio de Janeiro: Forense, 1986. 
FERRAGUT, Maria Rita. Presunções no direito tributário. São Paulo: Dialética, 2001.

FERREIRO LAPTZA, José Juán. El principio de legalidade y la reserva de ley. Revista de Direito Tributário, n. 50. São Paulo: Revista dos Tribunais, 1989.

FLUSSER, Vilém. Língua e realidade. $3^{\mathrm{a}}$. ed. São Paulo: Annablume, 2007.

GAMA, Tácio Lacerda. Competência tributária - fundamentos para uma teoria da nulidade. São Paulo: Noeses, 2009.

GUIBOURG, Ricardo. El fenômeno normativo. Buenos Aires: Astrea, 1987.

GODOI, Marciano Seabra de. Justiça, Igualdade e Direito Tributário. São Paulo: Dialética, 1999.

GONÇALVES, José Artur Lima. Imposto sobre a renda. Pressupostos constitucionais. São Paulo: Malheiros, 1997.

GRAU, Eros Roberto. A ordem econômica na Constituição de 1988. 14ª . edição. São Paulo: Malheiros, 2010.

_ Direito, Conceitos e Normas Jurídicas. São Paulo: RT, 1988.

_. Ensaio e Discurso sobre a Interpretação/Aplicação do Direito. São Paulo: Malheiros, 2002.

GRECO, Marco Aurélio. Substituição Tributária (Antecipação do Fato Gerador). 2a . ed. São Paulo: Malheiros, 2001. . Planejamento fiscal e interpretação da lei tributária. São Paulo: Dialética, 1998. 
GRUPENMACHER, Betina Treiger. Tratados internacionais em matéria tributária e ordem interna. São Paulo: Dialética, 1999.

.Tributação e Direitos Fundamentais. In: FISCHER, Octavio Campos(Coord.). Tributos e Direitos Fundamentais. São Paulo: Dialética, 2004.

HARET, Florence. Teoria e Prática das Presunções no Direito Tributário. São Paulo: Noeses, 2011.

HARGER, Marcelo. O SIMPLES e o princípio da isonomia. Revista Tributária e de Finanças Públicas, n. 40. São Paulo: Revista dos Tribunais, 2001.

HORVATH, Estevão. O Princípio do Não-Confisco no Direito Tributário. São Paulo: Dialética, 2002.

. Lançamento Tributário e "Autolançamento". 2a ed. São Paulo: Quartier Latin do Brasil, 2010.

IVO, Gabriel. Norma jurídica: produção e controle. São Paulo: Noeses, 2006.

KELSEN, Hans. Teoria Pura do Direito. Tradução de João Baptista Machado. São Paulo: Martins Fontes, 1991. . Teoria Geral do Direito e do Estado. $3^{\text {a }}$. edição. São Paulo: Martins Fontes, 1998.

LACOMBE, Américo Masset. Princípios Constitucionais Tributários. $2^{\mathrm{a}}$. edição. São Paulo: Malheiros, 2000.

LARENZ, Karl. Metodologia da ciência do direito. Tradução de José de Souza Brito e José Antonio Veloso. Lisboa: Fundação Calouste Gulbenkian, 1974.

LEITE, Harrison Ferreira. Simples: redução da carga tributária ou falácia? Revista Tributária e de Finanças Públicas, n. 63. São Paulo: Revista dos Tribunais, 2005.

LUHMANN, Niklas. Sociologia do Direito I. Rio de Janeiro: Templo Brasileiro, 1983. 
MACHADO, Brandão. ISS e o Arrendamento Mercantil. Revista Dialética de Direito Tributário, n. 141. São Paulo: Dialética,

. Distribuição disfarçada de lucros no Direito Comparado. In: Nogueira, Ruy Barbosa (coord.). Estudos Tributários - em homenagem a Rubens Gomes de Souza. São Paulo: Resenha Tributária, 1974.

MACHADO, Hugo de Brito. Curso de Direito Tributário. 29a . edição. São Paulo: Malheiros, 2008.

MACHADO SEGUNDO, Hugo de Brito. Ofenda ao princípio federativo? In: MAMEDE, Gladston et alli. Comentários ao Estatuto Nacional da Microempresa e da Empresa de Pequeno Porte. São Paulo: Atlas, 2007, p. 96-97.

MALTA, Christovão Piragibe Tostes; LEFÈVRE, Julia Brotero. Dicionário Jurídico. Edições Trabalhistas. 5a ed. 1987.

MANEIRA, Eduardo. O princípio da praticidade no Direito Tributário (substituição tributária, plantas de valores, retenções de fontes, presunções e ficções, etc): sua necessidade e seus limites. Revista Internacional de Direito Tributário, v. 2. Minas Gerais: Del Rey, julho/dezembro de 2004.

. Princípio da legalidade: especificação conceitual x tipicidade. Revista Internacional de Direito Tributário, v. 2. Minas Gerais: Del Rey, julho/dezembro de 2004.

MANGIERI, Francisco Ramos; MELO, Omar Augusto Leite. Super Simples Anotado e Comparado. São Paulo: Edipro, 2007.

MARCHI, Eduardo C. Silveira. Guia de Metodologia Jurídica. 2a . edição. São Paulo: Saraiva, 2009.

MARINS, James. Direito Processual Tributário - Administrativo e Judicial. São Paulo: Dialética, 2002. e BERTOLDI, Marcelo M. Simples Nacional - Estatuto da Microempresa e da Empresa de Pequeno Porte comentado. São Paulo: Revista dos Tribunais, 2007. 
MARTINS, Ives Granda da Silva. Lançamento de ICMS por Presunção. Revista dos Tribunais: cadernos de Direito Tributário e Finanças Públicas, n. 7. São Paulo: Revista dos Tribunais, 1994.

MATTOS, Aroldo Gomes de. ICMS: comentários à legislação nacional. São Paulo: Dialética, 2006.

MAXIMILIANO, Carlos. Hermenêutica e Aplicação do Direito. $3^{\mathrm{a}}$. edição. Rio de Janeiro: Forense, 1941.

MEIRELLES, Hely Lopes. Direito administrativo brasileiro. São Paulo: Malheiros, 1996.

MELO, José Eduardo Soares de. ICMS: teoria e prática. $6^{\mathrm{a}}$ edição. São Paulo: Dialética, 2003.

MENDONÇA, Cristiane. Competência tributária. São Paulo: Quartier Latin, 2004.

MORAES, Alexandre de. Direito Constitucional. 17ª edição. São Paulo: Atlas, 2005 .

MOUSSALLEM, Tárek Moysés. As Fontes do Direito Tributário. São Paulo: Max Limonad, 2001. . Revogação em matéria tributária. São Paulo: Noeses, 2005.

NABAIS, José Casalta. O Dever Fundamental de Pagar Impostos, Coimbra: Livraria Almedina, 1998.

Alguns aspectos da tributação de empresas em Portugal. Revista Tributária e de Finanças Públicas, n. 59. São Paulo: Revista dos Tribunais, 2004. 
NOGUEIRA, Ruy Barbosa. Da Interpretação e da aplicação das leis tributárias. 2a . edição. São Paulo: José Bushatsky, 1974. . Curso de Direito Tributário. 14ª edição. São Paulo: Saraiva, 1995.

NOVOA, César Garcia. Los métodos de simplificatión fiscal em la experiência latino americana. Referencia comparativa a los casos brasileno y argentino. Revista de Contabilidad y Tributación del Centro de Estudios Financieros, n. 59. Madri, outubro/2003.

OLIVEIRA, Yonne Dolácio. A Tipicidade no Direito Tributário Brasileiro. São Paulo: Saraiva, 1980.

- Presunções no Direito Tributário. In: Martins, Ives Gandra da Silva (Coord). Caderno de Pesquisas Tributárias: presunções no direito tributário. Vol. 9. São Paulo: Resenha Tributária, CEEU, 1984.

PAOLA, Leonardo Sperb de. Presunções e ficções no direito tributário. Belo Horizonte: Del Rey, 1997.

PAULSEN, Leandro. Direito Tributário. 9a . edição. Porto Alegre: Livraria do Advogado, 2007.

PEREZ DE AYALA, Jose Luis; GONZALEZ, Eusebio. Curso de Derecho Tributario. Tomo I. 6a . ed. Madri: Editoriales de Derecho Reunidas, 1991 . Las ficciones en el derecho tributario. Madrid: Editorial de Derecho Financiero, 1970.

PONTES, Helenílson Cunha. O princípio da praticidade no Direito Tributário (substituição tributária, plantas de valores, retenções de fontes, presunções e ficções, etc): sua necessidade e seus limites. Revista Internacional de Direito Tributário, v. 2. Minas Gerais: Del Rey, julho/dezembro de 2004. O Princípio da Proporcionalidade e o Direito Tributário. São Paulo: Dialética, 2000. 
PONTES DE MIRANDA. Tratado de direito privado. 2. ed. Rio de Janeiro: Borsoi, 1954. Parte Geral, t.III.

QUEIROZ, Luís César Souza. Sujeição Passiva Tributária. 2a . edição. Rio de Janeiro: Forense, 2002.

REALE, Miguel. Teoria tridimensional do direito. 5a . edição. São Paulo: Saraiva, 1994.

ROCHA, Valdir de Oliveira (Coord.). Grandes questões atuais do direito tributário. São Paulo: Dialética, 2005, v.9, p. 106.

ROSA, José Roberto. Substituição Tributária no ICMS. 2ª . edição. São Paulo: OTTONI, 2009.

ROTHMANN, Gerd Willi. Tributação, Sonegação e Livre Concorrência. In FERRAZ, Roberto (coord.). Princípios e Limites da Tributação 2. Os Princípios da Ordem Econômica e a Tributação. São Paulo: Quartier Latin, 2009.

SANTI, Eurico Marcos Diniz de. Decadência e Prescrição no Direito Tributário. São Paulo: Max Limonad, 2000. . Lançamento Tributário. 2a . edição. São Paulo: Max Limonad, 2001.

SILVA, José Afonso da. Curso de Direito Constitucional Positivo. São Paulo: Malheiros, 1996. . Aplicabilidade das Normas Constitucionais. $7^{\mathrm{a}}$. edição. São Paulo: Malheiros, 2009.

SILVA, Paulo Roberto Coimbra. A Substituição Tributária Progressiva nos Impostos Plurifásicos e Não-Cumulativos. Belo Horizonte: Del Rey, 2001.

SCHERKERKEWITZ, Iso Chaitz. Presunções e Ficções no Direito Tributário e no Direito Penal Tributário. Rio de Janeiro: Renovar, 2002. 
SCHOUERI, Luís Eduardo. Direito Tributário. São Paulo: Saraiva, 2011. . Discriminação de competências e competência residual. In: SCHOUERI, Luís Eduardo; ZILVETI, Fernando Aurélio (Coords.). Direito Tributário: estudos em homenagem a Brandão Machado. São Paulo: Dialética, 1998. . Distribuição Disfarçada de Lucros. São Paulo: Dialética, 1996. . Normas Tributárias Indutoras e Intervenção Econômica. Rio de Janeiro:

Forense, 2005. . Tributação e Liberdade. In: PIRES, Adilson Rodrigues; TÔRRES, Heleno Taveira (Coords.). Princípios de Direito Financeiro e Tributário: estudos em homenagem ao Professor Ricardo Lobo Torres. Rio de Janeiro: Renovar, 2006.

SMITH, Adam. Riqueza das Nações. São Paulo: Folha de São Paulo, 2010.

SOTTO, Débora. Tributação da Microempresa (ME) e da Empresa de Pequeno Porte (EPP). São Paulo: Quartier Latin, 2007.

TELLES JUNIOR, Goffredo da Silva. O Direito Quântico. São Paulo: Max Limonad, 1980.

TIPKE, Klaus. Princípios de Igualdade e ideia de sistema no Direito Tributário. In MACHADO, Brandão (coord.). Direito Tributário. Estudos em homenagem ao professor Ruy Barbosa Nogueira. São Paulo: Saraiva, 1984. ; YAMASHITA, Douglas. Justiça Fiscal e Princípio da Capacidade Contributiva. São Paulo: Malheiros, 2002.

. Moral Tributária do Estado e dos Contribuintes. Tradução: Luiz Dória Furquim. Porto Alegre: Sergio Antonio Fabris, 2012.

TOMÉ, Fabiana Del Padre. A prova no direito tributário. São Paulo: Noeses, 2005.

TÔRRES, Heleno Taveira. Direito Tributário e Direito Privado - Autonomia Privada, Simulação, Elusão Tributária. São Paulo: Revista dos Tribunais, 2003. 
. Substituição Tributária - regime constitucional, classificação e relações jurídicas (materiais e processuais), Revista Dialética de Direito Tributário, n.70. São Paulo: Dialética, 2001, p. 87-88.

- Garantias Constitucionais ao Controle sobre Preços de Transferência (Legalidade e Uso de Presunções no Arbitramento da Base de Cálculo dos Tributos, a partir do Controle de Preços de Transferência. O Direito ao Emprego do Melhor Método. Um Caso: Limites ao Uso do PRL-60 na Importação). In: FISCHER, Octavio Campos(Coord.). Tributos e Direitos Fundamentais. São Paulo: Dialética, 2004.

TORRES, Ricardo Lobo. Normas de Interpretação e Integração do Direito Tributário. $4^{\mathrm{a}}$. edição. Rio de Janeiro: Renovar, 2006.

. Curso de Direito Financeiro e Tributário. 10a . edição. Rio de Janeiro: Renovar, 2003.

- Liberdade, Consentimento e Princípios de Legitimação do Direito Tributário. Revista Internacional de Direito Tributário, v. 5. Minas Gerais: Del Rey, janeiro/julho de 2006.

. O princípio da Tipicidade no Direito Tributário. Revista Eletrônica de Direito Administrativo Econômico, Salvador, Instituto de Direito Público da Bahia, $\mathrm{n}^{\circ}$. 5, fev/ar/abr de 2006. Disponível na Internet: < http://www.direitodoestado.com.br>. Acesso em: 15 de fevereiro de 2013.

. Sistemas Constitucionais Tributários. Rio de Janeiro: Forense, 1986.

. Tratado de Direito Constitucional, Financeiro e Tributário, vol. II, Valores e Princípios Constitucionais Tributários. Rio de Janeiro: Renovar, 2005.

UCKMAR, Victor. Princípios Comuns de Direito Constitucional Tributário. $2^{\mathrm{a}}$. edição. Trad. Marco Aurélio Greco. São Paulo: Malheiros, 1999.

VALADÃO, Marcos Aurélio Pereira. Limitações Constitucionais ao Poder de Tributar e Tratados Internacionais. Belo Horizonte: Del Rey, 2000.

VANONI, Ezio. Natureza e Interpretação das Leis Tributárias. Rio de Janeiro: Financeiras, 1932.

VILANOVA, Lourival. As Estruturas Lógicas e o Sistema do Direito Positivo. $3^{\mathrm{a}}$. edição. São Paulo: Noeses, 2005. 
. Causalidade e Relação no Direito. 2a . edição. São Paulo: Saraiva, 1989.

VELOSO, Andrei Pitten. Conceitos e competências tributárias. São Paulo: Dialética, 2005.

XAVIER, Alberto. Do Lançamento - Teoria Geral do Ato, do Procedimento e do Processo Tributário. 2a . edição. Rio de Janeiro: Forense, 2001.

—. Tipicidade da Tributação, Simulação e Norma Antielisiva. São Paulo: Dialética, 2001.

YAMASHITA, Douglas. Confisco como efeito tributário e sua proibição constitucional. Repertório IOB de Jurisprudência. Belo Horizonte, n. 10, p. 259, 2a. quinzena, maio. 2000. Caderno 1.

ZILVETI, Fernando Aurélio. Federação e Sistema Tributário. In SOUZA, Priscila (coord.). VII Congresso Nacional de Estudos Tributários do IBET - Sistema Tributário Brasileiro e a Crise Atual. São Paulo: Noeses, 2009.

. Capacidade contributiva e mínimo existencial. SCHOUERI, Luís Eduardo; ZILVETTI, Fernando Aurélio (coords.). Direito Tributário - Estudos em homenagem a Brandão Machado. São Paulo: Dialética, 1998.

Princípios de Direito Tributário e a Capacidade Contributiva. São Paulo: Quartier Latin, 2004. 